\title{
National Cost-effectiveness of ASHRAE Standard 90.1-2010 Compared to ASHRAE Standard 90.1-2007
}

BA Thornton

MA Halverson

M Myer

November 2013
SA Loper

EE Richman

DB Elliott $\checkmark$ Mendon

MI Rosenberg

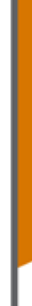




\title{
DISCLAIMER
}

This report was prepared as an account of work sponsored by an agency of the United States Government. Neither the United States Government nor any agency thereof, nor Battelle Memorial Institute, nor any of their employees, makes any warranty, express or implied, or assumes any legal liability or responsibility for the accuracy, completeness, or usefulness of any information, apparatus, product, or process diselosed, or represents that its use would not infringe privately owned rights. Reference herein to any specific commercial product, process, or service by trade name, trademark, manufacturer, or otherwise does not necessarily constitute or imply its endorsement, recommendation, or favoring by the United States Government or any agency thereof, or Battelle Memorial Institute. The views and opinions of authors expressed herein do not necessarily state or reflect those of the United States Government or any agency thereof.

\author{
PACIFIC NORTHWEST NATIONAL LABORATORY \\ operated by \\ BATTELLE \\ for the \\ UNITED STATES DEPARTMENT OF ENERGY \\ under Contract DE-AC05-76RL01830
}

Printed in the United States of America

Available to DOE and DOE contractors from th Office of Scientific and Technical Information,

P.O. Box 62, Oak Ridge, TN 37831-0062;

ph: (865) 576-8401

fax: $(865) 576-5728$

email: reports@adonis.osti.gov

\author{
Available to the public from the National Technical Information Service, \\ U.S. Department of Commerce, 5285 Port Royal Rd., Springfield, VA 22161 \\ ph: (800) 553-6847 \\ fax: (703) 605-6900 \\ email: orders@ntis.fedworld.gov \\ online ordering: http://www.ntis.gov/ordering.htm
}

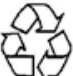

This document was printed on recycled paper. 


\section{National Cost-effectiveness of ASHRAE Standard 90.1-2010 Compared to ASHRAE Standard 90.1-2007}

$\begin{array}{lll}\text { BA Thornton } & \text { SA Loper } & \text { V Mendon } \\ \text { MA Halverson } & \text { EE Richman } & \text { MI Rosenberg } \\ \text { M Myer } & \text { DB Elliott } & \end{array}$

November 2013

Prepared for

The U.S. Department of Energy

under Contract DE-AC05-76RL01830

Pacific Northwest National Laboratory

Richland, Washington 99352 



\section{Executive Summary}

Pacific Northwest National Laboratory (PNNL) prepared this analysis for the U.S. Department of Energy (DOE) Building Energy Codes Program. DOE supports the upgrade and implementation of building energy codes and standards, which set minimum requirements for energy-efficient design and construction for new and renovated buildings, and impact energy use and greenhouse gas emissions for the life of buildings. Continuous improvement of building energy efficiency is achieved by periodically updating model energy codes. Through consensus-based code development processes, DOE recommends revisions and amendments, supporting technologically feasible and economically justified energy efficiency measures. Ensuring that code changes impacting the cost of building construction, maintenance, and energy services are cost-effective encourages their adoption and implementation.

The purpose of this analysis is to examine the cost-effectiveness of the 2010 edition of ANSI/ASHRAE/IES ${ }^{1}$ Standard 90.1. Standard 90.1 is the model energy standard for commercial and multi-family residential buildings over three floors (ECPA, Public Law 94-385). PNNL analyzed the costeffectiveness of changes in Standard 90.1 from 90.1-2007 to 90.1-2010, as applied in the United States. During the development of new editions of Standard 90.1, the cost-effectiveness of individual changes (addenda) is often calculated to support the deliberations of Standard Standing Project Committee (SSPC) 90.1. The process does not include analysis of the cost-effectiveness of the entire package of addenda from one version of the standard to the next. Providing States with an analysis of cost-effectiveness may encourage more rapid adoption of newer editions of energy codes based on Standard 90.1. This information may also inform the development of future editions of Standard 90.1.

To establish the cost-effectiveness of 90.1-2007, three main tasks were addressed:

- Identification of building elements impacted by the updated standard

- Allocation of associated costs

- Cost-effectiveness analysis of required changes

In addition, energy cost differences were needed to determine cost-effectiveness, which were determined previously under the development of 90.1-2010, as described below.

The current analysis builds on the previous PNNL analysis of the energy use and energy cost saving impacts of 90.1-2010 compared to 2004 and 2007 editions, which was documented in the PNNL technical report titled Achieving the 30\% Goal: Energy and Cost Savings Analysis of ASHRAE Standard 90.1-2010 (Thornton et al. 2011). Analysis done in support of the previous report indicates that 90.1-2010 can achieve $24.5 \%$ site energy savings and 23.4\% energy cost savings relative to 90.1-2007, with plug and process load energy excluded (these energy uses are nearly unregulated by Standard 90.1). Energy savings of $18.9 \%$ and energy cost savings of $18.9 \%$ were demonstrated for the whole building energy use,

\footnotetext{
${ }^{1}$ ANSI - American National Standards Institute; ASHRAE - American Society of Heating, Refrigerating, and AirConditioning Engineers; IES - Illuminating Engineering Society; IESNA Illuminating Engineering Society of North America ( IESNA rather than IES was identified with Standard 90.1 prior to 90.1-2010)
} 
including plug and process loads. Chapter 5 and Appendix $\mathrm{C}$ of this report present these energy simulation results as used in the cost-effectiveness analysis.

The energy saving analysis of Standard 90.1 in the report described above utilized a suite of 16 prototype EnergyPlus building models. Prototypes were simulated in 17 climate locations representing all eight U.S. climate zones. The cost-effectiveness analysis in this report used a subset of prototypes and climate locations, providing coverage of nearly all of the changes in Standard 90.1 from the 2007 to 2010 edition that affect energy savings, equipment and construction costs, and maintenance, including conventional HVAC systems used in commercial buildings. Each prototype building was analyzed in each climate location for a total of 30 cost-effectiveness assessments. The following prototype buildings and climate locations were included in the analysis:

\begin{tabular}{ll} 
Prototypes & Climate Locations \\
\cline { 2 - 2 } Small Office & 2A Houston, Texas (hot, humid) \\
Large Office & 4A Baltimore, Maryland (mixed, humid) \\
Standalone Retail & 3A Memphis, Tennessee (warm, humid) \\
Primary School & 5A Chicago, Illinois (cool, humid) \\
Small Hotel & 3B Albuquerque, New Mexico (hot, dry) \\
Mid-rise Apartment &
\end{tabular}

A primary input to the cost-effectiveness analysis was the incremental costs for the addenda to 90.12007 that were included in 90.1-2010. Of the 109 total addenda to 90.1-2007, 41 had quantified energy savings that were modeled in the 90.1-2010 energy savings analysis. The remaining addenda were not considered to have quantifiable savings, or do not affect the sections of 90.1 that directly impact building energy usage. Of the 41 addenda with quantified energy savings, 38 were modeled in the six prototypes and were included with the cost estimate. The remaining three addenda affect building systems that were not included in the prototypes.

Incremental costs were developed for building systems or equipment that changed due to addenda. In some cases, the prototype models do not include sufficient design details to provide the basis for cost estimates, and additional design detail was needed to complete this analysis. PNNL relied on the help of professional cost estimators and engineering consultants for development of these design details, and for cost estimating.

Three cost-effectiveness metrics are used in this report:

- $\quad$ Life-cycle cost analysis (LCCA)

- SSPC 90.1 scalar ratio method

- Simple payback

The LCCA is a present value life-cycle cost analysis based on the Federal Energy Management Program (FEMP) LCC method (NIST 1995). The present value of the incremental costs for new construction, replacement, maintenance, and energy of 90.1-2010 compared to 90.1-2007 were analyzed. If the present value of the 90.1-2010 costs is less than the present value of the 90.1-2007 costs, then 90.12010 is cost-effective. 
The scalar method is a modified life-cycle cost approach used by the ASHRAE SSPC 90.1 to evaluate individual addenda (McBride 1995). This method creates a threshold, or scalar ratio limit, for costeffectiveness that can be compared to simple payback when evaluating specific addenda. The scalar ratio limit is calculated using the same present value analysis factors that a conventional LCCA uses. The calculation includes first cost, annual energy cost savings, annual maintenance, inflation, fuel escalation and simplified assumptions about taxes, and borrowing including the mortgage deduction. This method does not account for replacement costs, since the analysis ends with the useful life of the individual item. The scalar ratio is the incremental first cost divided by the difference of the annual energy cost savings and maintenance costs, the same as simple payback. An addendum is considered cost-effective if the scalar ratio of a specific addendum is less than the scalar ratio limit.

PNNL modified the SSPC 90.1 scalar method to evaluate the combination of all of the changes in Standard 90.1, including replacement costs. The modified scalar method calculates the scalar ratio as the first costs plus the present value of the replacement costs for all measures divided by the difference of annual energy cost savings and annual incremental maintenance costs.

Simple payback is the incremental first cost divided by the difference of annual energy cost savings and annual incremental maintenance costs. This method ignores replacement costs and the time value of money. This is a rough approximation, particularly when there are multiple components with different replacement lives combined together. Simple payback is provided for comparison; there is no defined parameter to compare to for determining cost-effectiveness with simple payback.

Table ES-1 summarizes the cost-effectiveness results. Findings demonstrate that $90.1-2010$ is costeffective overall relative to 90.1-2007 under the LCCA and modified SSPC 90.1 scalar method for the representative prototypes and climate locations. 
Table ES-1 Summary of Cost-effectiveness Analysis

\begin{tabular}{|c|c|c|c|c|c|c|}
\hline \multirow{2}{*}{ Prototype } & & \multicolumn{5}{|c|}{ Climate Zone } \\
\hline & & 2A Houston & 3A Memphis & 3B El Paso & 4A Baltimore & 5A Chicago \\
\hline \multicolumn{7}{|c|}{ Life Cycle Cost Net Savings } \\
\hline \multirow[t]{2}{*}{ Small Office } & Total & $\$ 9,500$ & $\$ 12,700$ & $\$ 10,400$ & $\$ 6,100$ & $\$ 14,300$ \\
\hline & $\$ / \mathrm{ft}^{2}$ & $\$ 1.73$ & $\$ 2.31$ & $\$ 1.89$ & $\$ 1.11$ & $\$ 2.60$ \\
\hline \multirow[t]{2}{*}{ Large Office } & Total & $\$ 1,810,000$ & $\$ 1,560,000$ & $\$ 990,000$ & $\$ 1,500,000$ & $\$ 1,730,000$ \\
\hline & $\$ / \mathrm{ft}^{2}$ & $\$ 3.63$ & $\$ 3.13$ & $\$ 1.99$ & $\$ 3.01$ & $\$ 3.47$ \\
\hline \multirow[t]{2}{*}{ Standalone Retail } & Total & $\$ 110,000$ & $\$ 95,600$ & $\$ 99,200$ & $\$ 74,000$ & $\$ 121,000$ \\
\hline & $\$ / \mathrm{ft}^{2}$ & $\$ 4.46$ & $\$ 3.87$ & $\$ 4.02$ & $\$ 3.00$ & $\$ 4.90$ \\
\hline \multirow[t]{2}{*}{ Primary School } & Total & $\$ 205,000$ & $\$ 195,000$ & $\$ 354,000$ & $\$ 197,000$ & $\$ 307,000$ \\
\hline & $\$ / \mathrm{ft}^{2}$ & $\$ 2.77$ & $\$ 2.64$ & $\$ 4.79$ & $\$ 2.66$ & $\$ 4.15$ \\
\hline \multirow[t]{2}{*}{ Small Hotel } & Total & $\$ 304,450$ & $\$ 328,000$ & $\$ 316,000$ & $\$ 284,700$ & $\$ 325,000$ \\
\hline & $\$ / \mathrm{ft}^{2}$ & $\$ 7.05$ & $\$ 7.59$ & $\$ 7.31$ & $\$ 6.59$ & $\$ 7.52$ \\
\hline \multirow[t]{2}{*}{ Mid-rise Apartment } & Total & $\$ 20,400$ & $\$ 25,500$ & $\$ 18,300$ & $\$ 30,800$ & $\$ 41,800$ \\
\hline & $\$ / \mathrm{ft}^{2}$ & $\$ 0.60$ & $\$ 0.76$ & $\$ 0.54$ & $\$ 0.91$ & $\$ 1.24$ \\
\hline \multicolumn{7}{|c|}{ Simple Payback (years) } \\
\hline Small Office & & 11.6 & 9.5 & 10.7 & 15.5 & 8.7 \\
\hline Large Office & & 3.3 & 4.1 & 4.7 & 4.1 & 2.2 \\
\hline Standalone Retail & & 5.8 & 7.0 & 5.4 & 8.8 & 5.7 \\
\hline Primary School & & 6.1 & 6.7 & 0.8 & 6.7 & 4.5 \\
\hline Small Hotel & & 0.9 & immediate & immediate & 1.4 & immediate \\
\hline Mid-rise Apartment & & 13.0 & 11.3 & 13.9 & 10.1 & 8.0 \\
\hline \multicolumn{7}{|c|}{ Scalar Ratio (Limit 20.2) } \\
\hline Small Office & & 9.7 & 6.5 & 8.7 & 14.1 & 5.9 \\
\hline Large Office & & 4.8 & 5.8 & 7.2 & 5.9 & 3.1 \\
\hline Standalone Retail & & 6.6 & 8.2 & 5.2 & 10.1 & 6.0 \\
\hline Primary School & & 8.9 & 9.6 & 0.7 & 9.8 & 6.4 \\
\hline Small Hotel & & -23.4 & -24.8 & -24.8 & -27.3 & -27.9 \\
\hline Mid-rise Apartment & & 9.0 & 7.8 & 9.6 & 7.0 & 5.6 \\
\hline
\end{tabular}




\section{Acknowledgments}

This report was prepared by Pacific Northwest National Laboratory (PNNL) for the U.S. Department of Energy (DOE) Building Energy Codes Program. The authors would like to thank Jeremy Williams at DOE for providing oversight.

The authors would like to thank the members of the ASHRAE Standing Standards Project Committee (SSPC) for 90.1 for their review of the cost estimates.

The authors also recognize Bing Liu, Manager of the Building Energy Codes Program at PNNL, and Michael Rosenberg, the task manager, for their strong support of this task.

This work was truly a team effort, and the authors would like to express their deep appreciation to everyone who contributed to its completion.

Brian Thornton

Pacific Northwest National Laboratory 



\section{Acronyms and Abbreviations}

\begin{tabular}{|c|c|}
\hline AHU & air handling unit \\
\hline ANSI & American National Standards Institute \\
\hline ASHRAE & American Society of Heating, Refrigerating and Air-Conditioning Engineers \\
\hline BECP & Building Energy Codes Program \\
\hline Btu & British thermal units \\
\hline $\mathrm{Btu} / \mathrm{h}$ & British thermal units per hour \\
\hline CAV & constant air volume \\
\hline CBECS & Commercial Buildings Energy Consumption Survey \\
\hline CDD & cooling degree days \\
\hline CFL & compact fluorescent lamp \\
\hline CFM & cubic feet per minute \\
\hline CHW & chilled water \\
\hline $\mathrm{CU}$ & coefficient of utilization \\
\hline DDC & direct digital control \\
\hline DOE & U.S. Department of Energy \\
\hline $\mathrm{DX}$ & direct expansion \\
\hline EER & energy efficiency ratio \\
\hline EIA & Energy Information Administration \\
\hline EPAct & Energy Policy Act \\
\hline ERV & energy recovery ventilator \\
\hline $\mathrm{E}_{\mathrm{t}}$ & thermal efficiency \\
\hline FEMP & Federal Energy Management Program \\
\hline FLR & floor \\
\hline $\mathrm{ft}$ & feet or foot \\
\hline $\mathrm{ft}^{2}$ & square feet or square foot \\
\hline gpm & gallons per minute \\
\hline HDD & heating degree day \\
\hline hp & horsepower \\
\hline HVAC & heating, ventilating, and air conditioning \\
\hline IECC & International Energy Conservation Code \\
\hline IEER & integrated energy efficiency ratio \\
\hline IES & Illuminating Engineering Society \\
\hline IESNA & Illuminating Engineering Society of North America \\
\hline IPLV & integrated part load value \\
\hline $\mathrm{kVA}$ & kilo volt amperes \\
\hline LBNL & Lawrence Berkeley National Laboratory \\
\hline
\end{tabular}


LCCA

$\operatorname{lm}$

LPD

LSC

MHC

mph

MSC

$\mathrm{NC}^{3}$

NFRC

NR

NREL

OH\&P

PI

PNNL

PSZ-AC

PTAC

PTHP

RTU

SEER

SHGC

SMACNA

SSPC

SRI

SWG

U-factor

UPV

VAV

VFD

VRP

W

wb

w.c.

WWR life-cycle cost analysis

lumens

lighting power density

Lighting Subcommittee (SSPC 90.1)

McGraw-Hill Construction

miles per hour

Mechanical Subcommittee (SSPC 90.1)

National Commercial Construction Characteristics

National Fenestration Rating Council

not required

National Renewable Energy Laboratory

overhead and profit

Progress Indicator

Pacific Northwest National Laboratory

packaged single zone air conditioner

packaged terminal air conditioner

packaged terminal heat pump

roof top unit

seasonal energy efficiency ratio

solar heat gain coefficient

Sheet Metal and Air Conditioning Contractors Association

Standing Standard Project Committee

solar reflectance index

Simulation Working Group (SSPC 90.1)

thermal transmittance

uniform present value

variable air volume

variable frequency drive

ventilation rate procedure

watt

wet bulb (temperature)

water column

window-to-wall ratio 


\section{Contents}

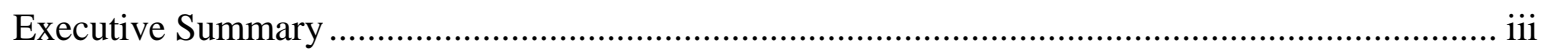

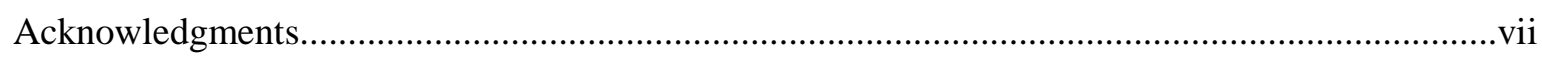

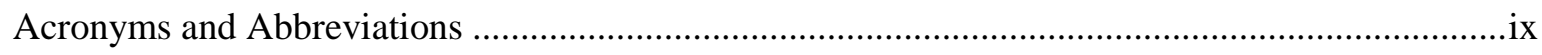

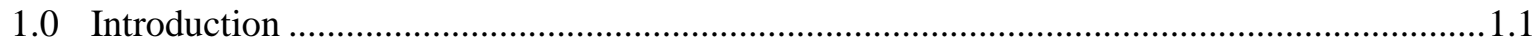

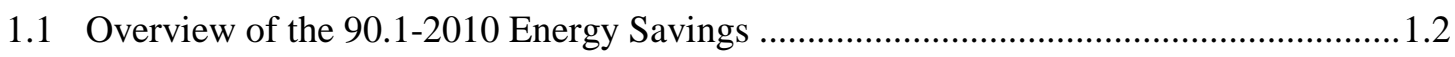

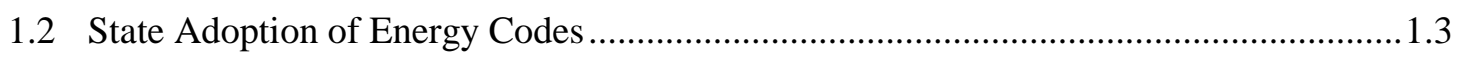

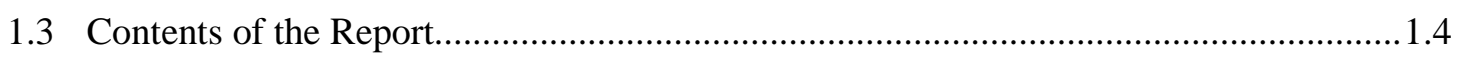

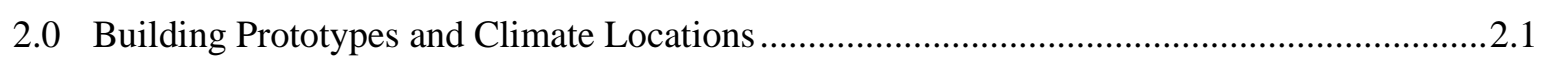

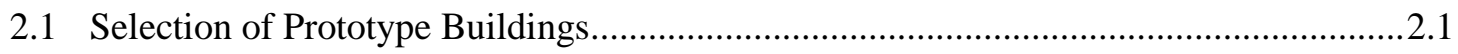

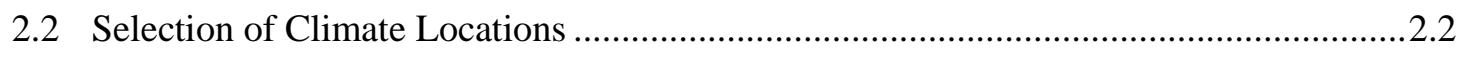

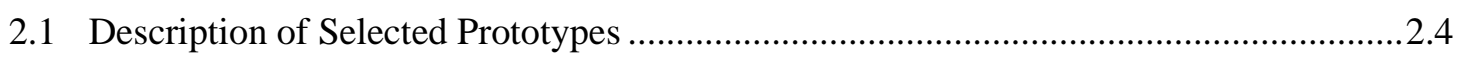

3.0 Cost Estimate Items from 90.1-2007 Addenda....................................................................

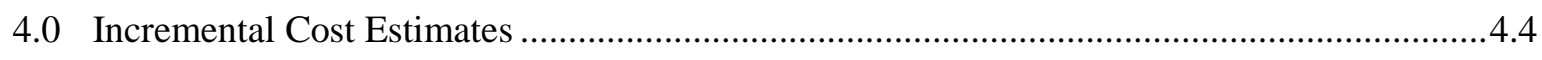

4.1 Incremental Cost Estimate Approach....................................................................4.4

4.1.1 Source of Cost Estimates................................................................................4.4

4.1.2 Cost Parameters........................................................................................... 4.5

4.1.3 Cost Estimate Spreadsheet Workbook .........................................................4.6

4.2 Cost Estimate Descriptions ....................................................................................

4.2.1 Heating, Ventilating and Air Conditioning ......................................................4.7

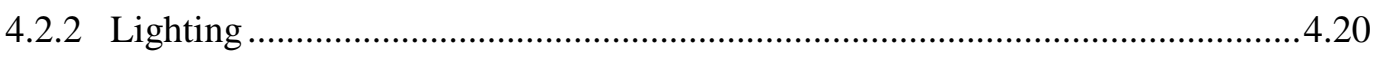

4.2.3 Building Envelope, Power and Other Equipment ...........................................4.27

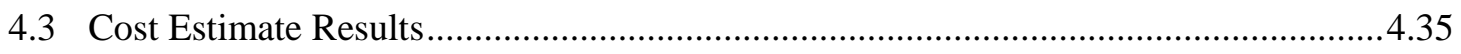

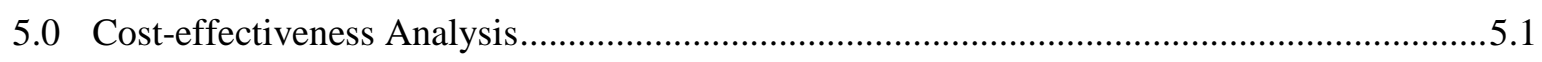

5.1 Cost-effectiveness Analysis Methodology ……............................................................ 5.1

5.1.1 Life-Cycle Cost Analysis ............................................................................. 5.1

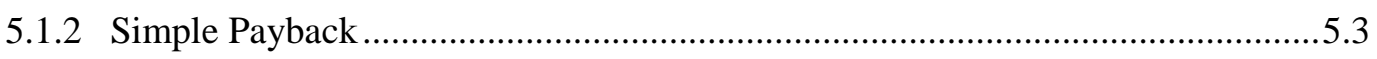

5.1.3 SSPC 90.1 Scalar Method ….......................................................................... 5.4

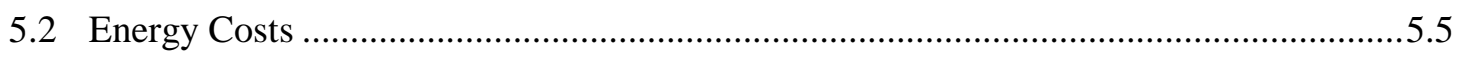

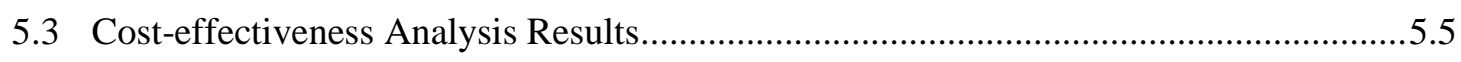

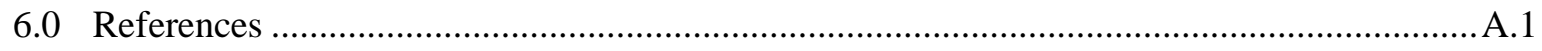

Appendix A Energy Modeling Prototype Building Descriptions ...............................................A.4

Appendix B Incremental Cost Estimate Summary ............................................................... B. 1

Appendix C Energy Results 90.1-2007 and 90.1-2010............................................................... 


\section{Figures}

Figure 1.1. Current Commercial Building Energy Code Adoption Status.....................................1.4

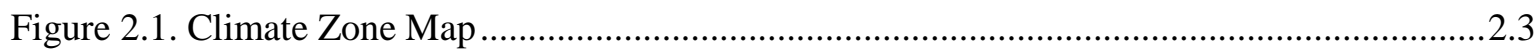

Figure 3.1. Quantity of Addenda Included in the Cost Estimate by Standard 90.1 Chapter.............3.1

Figure 4.1. Small Office Air Distribution System ..........................................................................9

\section{Tables}

Table 2.1. Prototype Buildings .................................................................................................2.2

Table 2.2. HVAC Systems in Selected Prototypes ........................................................................2.2

Table 2.3 Climate Locations by Climate Subzones …...................................................................

Table 2.4. Overview of Six Selected Prototypes .......................................................................... 2.5

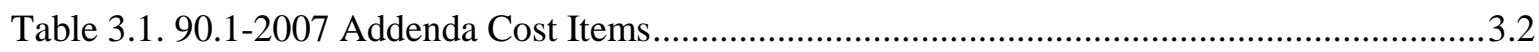

Table 4.1. Sources of Cost Estimates by Cost Category ................................................................... 4.5

Table 4.2. Cost Estimate Adjustment Parameters........................................................................4.6

Table 4.3. Small Office Duct Details for One HVAC System..................................................4.10

Table 4.4. Energy Recovery Requirements by Climate Zone and Outdoor Air Fraction ..............4.16

Table 4.5. 90.1-2007 and 90.1-2010 Chiller Efficiencies ..............................................................20

Table 4.6. Occupancy Sensor Control Types..............................................................................24

Table 4.7. Application of Daylighting Controls by Prototype and Space....................................4.24

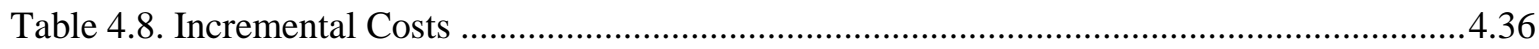

Table 4.9. Comparison of Total Building Cost and Incremental Cost (per $\mathrm{Ft}^{2}$ and percentage)...4.37

Table 5.1. Life Cycle Cost Analysis Parameters................................................................................

Table 5.2. Scalar Method Economic Parameters and Scalar Ratio Limit ......................................5.4

Table 5.3. Annual Energy Cost Savings, 90.1-2010 Compared to 90.1-2007 ...............................5.5

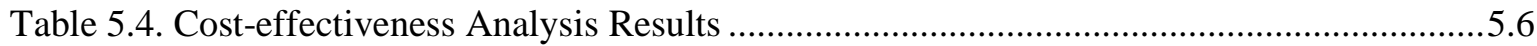




\subsection{Introduction}

This study was conducted by Pacific Northwest National Laboratory (PNNL) in support of the U.S. Department of Energy (DOE) Building Energy Codes Program (BECP). BECP was founded in 1993 in response to the Energy Policy Act of 1992, which mandated that DOE participate in the development process for national model codes and that DOE help states adopt and implement progressive energy codes. DOE has supported the development and implementation of more stringent building energy codes since the 1970s, but the BECP was the first DOE program assigned specific mandates with regard to energy codes.

Building energy codes set baseline minimum requirements for energy efficient design and construction for new and renovated buildings, and impact energy use and emissions for the life of the buildings. Energy codes are part of the greater collection of documents which govern the design and construction of buildings for the health and life safety of occupants. Improving these documents generates consistent and long-lasting energy savings.

ASHRAE Standard 90.1 is the national model energy standard for commercial and multi-family residential buildings higher than three floors, which is the subject of this report. The 2007 and 2010 editions of Standard 90.1 are the primary focus of this report. These standards are referred to as 90.1-2007 and 90.1-2010 respectively, or as Standard 90.1 when referring to multiple editions of the Standard.

DOE supports the incremental upgrading of the model energy codes, and states' adoption, implementation, and enforcement of those documents as they are upgraded. When the model building energy codes are being updated, DOE takes an active leadership role, including:

- Recommending amendments to the model energy codes during cyclical updates,

- Seeking adoption of all technologically feasible and economically justified energy efficiency measures in these documents,

- Participating in the processes that update and maintain these documents.

PNNL has played a major role in supporting DOE code efforts, and is closely involved in the upgrading of the model codes. Specifically, PNNL provides significant assistance to the ASHRAE Standing Standard Project Committee for 90.1 (SSPC 90.1), which is responsible for developing Standard 90.1. This assistance ranges from providing leadership and voting members to development committees, to developing change proposals (called addenda) for codes. PNNL also conducts requested analyses and supports DOE determinations published in the Federal Register. Determinations confirm whether or not each new edition of the model codes will improve the energy efficiency of buildings. ${ }^{1}$

The process for adopting new editions of Standard 90.1 does not include analysis of the costeffectiveness of the combined changes from one edition to the next. The cost-effectiveness of individual changes, known as addenda, is often evaluated to inform SSPC 90.1 decisions. DOE asked PNNL to analyze the cost-effectiveness of 90.1-2010 as a whole compared to 90.1-2007, using a life-cycle cost analysis (LCCA). DOE seeks to provide states with cost-effectiveness information to encourage more

\footnotetext{
${ }^{1}$ For more information on the DOE Determination of energy savings, see http://www.energycodes.gov/regulations/determinations
} 
rapid adoption of newer editions of commercial energy codes based on Standard 90.1, as well as to be used in the development of future editions of the Standard. The cost-effectiveness analysis is the subject of this report.

\subsection{Overview of the 90.1-2010 Energy Savings}

In 2007 DOE and ASHRAE agreed to develop advanced commercial building codes, targeting 30\% energy savings compared to 90.1-2004. This agreement initiated the efforts by DOE and ASHRAE to upgrade Standard 90.1 (through the SSPC 90.1) which culminated with the release of 90.1-2010.

The 30\% energy savings goal led to an increase in the level of activity and enhancement of Standard 90.1. For the first time, a percentage goal was set for developing the new edition of the Standard. Prior to the development of 90.1-2010, the previous three updates (Standard 90.1-2001, -2004, and -2007 editions) generated 34, 32 and 44 approved addenda, respectively. By the time 90.1-2010 was published in October 2010, 109 addenda to 90.1-2007 were approved and incorporated in the new edition.

PNNL was directed by DOE to provide both leadership and technical analysis support for developing 90.1-2010 to reach the $30 \%$ energy savings goal. To closely measure progress towards the goal, PNNL developed a new metric and process named the "Progress Indicator" (PI). The PI was a process to measure progress toward the $30 \%$ improvement goal relative to the baseline 90.1-2004. Using the PI, PNNL periodically reported energy and energy cost saving impacts for approved addenda to both DOE and the SSPC 90.1 during the three-year development cycle. PNNL conducted this analysis with inputs from many other contributors and sources of information. In particular, guidance and direction were provided by an advisory group under the auspices of the SSPC 90.1. The technical analysis process, results and changes to 90.1-2004 and 90.1-2007 that led to 90.1-2010, were presented in Achieving the 30\% Goal: Energy and Cost Savings Analysis of ASHRAE Standard 90.1-2010, referred to in this report as Energy and Cost Savings Analysis of ASHRAE Standard 90.1-2010 (Thornton et al. 2011).

The simulation utilized a suite of 16 prototype EnergyPlus building models. The prototype buildings were simulated in 17 cities which represent the climate zones and subzones referenced by the requirements in Standard 90.1. Climate zones are defined by temperature profile, with subzones within the climate zones defined by humidity. The United States includes 15 of these climate subzones. These prototype models and climate locations were described in detail in Energy and Cost Savings Analysis of ASHRAE Standard 90.1-2010 and briefly in Section 2 of this report.

The goal of 30\% savings for 90.1-2010 compared to 90.1-2004 was achieved. Simulations demonstrated a national average of 32.7\% site energy savings and 29.5\% energy cost savings, if plug and process load energy, which are nearly unregulated, are excluded in the percentage saving calculation and $25.6 \%$ and $23.2 \%$ respectively with all simulated energy included (Thornton et al. 2011).

A separate goal for energy savings for 90.1-2010 compared to 90.1-2007 was never established and the separate results for this comparison were not presented in Energy and Cost Savings Analysis of ASHRAE Standard 90.1-2010. However, these simulations were completed by PNNL during the same analysis and the results are $24.5 \%$ site energy savings and $23.4 \%$ energy cost savings, if plug and process load energy are excluded and $18.9 \%$ site energy savings and $18.1 \%$ energy cost savings with all modeled energy uses included. The energy cost savings for 90.1-2010 versus 90.1-2007 with all energy uses included are used for this cost-effectiveness analysis. 


\subsection{State Adoption of Energy Codes}

Standard 90.1 is not implemented or enforced by ASHRAE or DOE for individual buildings. States and local jurisdictions adopt and enforce building energy codes. For example, some states adopt the commercial provisions of the International Energy Conservation Code (IECC), which incorporates Standard 90.1 by reference. Some states choose to adopt Standard 90.1 directly as their code, while other states and local jurisdictions develop their own building energy code, or add local amendments (DOE 2012A).

For each new edition of Standard 90.1, DOE issues a determination whether the new edition will improve energy efficiency in commercial buildings relative to the previous edition of Standard 90.1. The determination is required by Section 304 of the Energy Conservation and Production Act (ECPA, Public Law 94-385), as modified by the Energy Policy Act of 1992. DOE is required to publish the determination within one year after the newest edition of Standard 90.1 is published. On October 19, 2011, the Federal Register published the determination that 90.1-2010 will improve energy efficiency relative to 90.1-2007.

Once an affirmative determination is made, states are required by EPAct 1992 to certify that their commercial building code meets or exceeds the requirements of the new standard within two years.

(B)(i) If the [DOE] Secretary makes an affirmative determination under subparagraph (A), each State shall, not later than 2 years after the date of the publication of such determination, certify that it has reviewed and updated the provisions of its commercial building code regarding energy efficiency in accordance with the revised standard for which such determination was made. Such certification shall include a demonstration that the provisions of such State's commercial building code regarding energy efficiency meet or exceed such revised standard (DOE 2012B from ECPA, Public Law 94-385, Section 304, as amended by Section 101 of EPAct 1992).

DOE is required to provide technical assistance and funding to states to help them review and update state energy codes, as well as to implement, enforce, and evaluate compliance with state codes. DOE also is required to permit certification extensions if the state demonstrates a good faith effort to comply with its requirement and has made significant progress toward compliance. The cost-effectiveness analysis covered in this report is considered part of DOE's technical assistance effort to encourage states to adopt the newest edition of Standard 90.1 or its equivalent. States are at various stages of incorporating the latest edition of Standard 90.1 or its equivalent into their building codes. Figure 1.1 shows the current applicable energy standard or code that most closely matches the state's regulation (DOE2012A). 


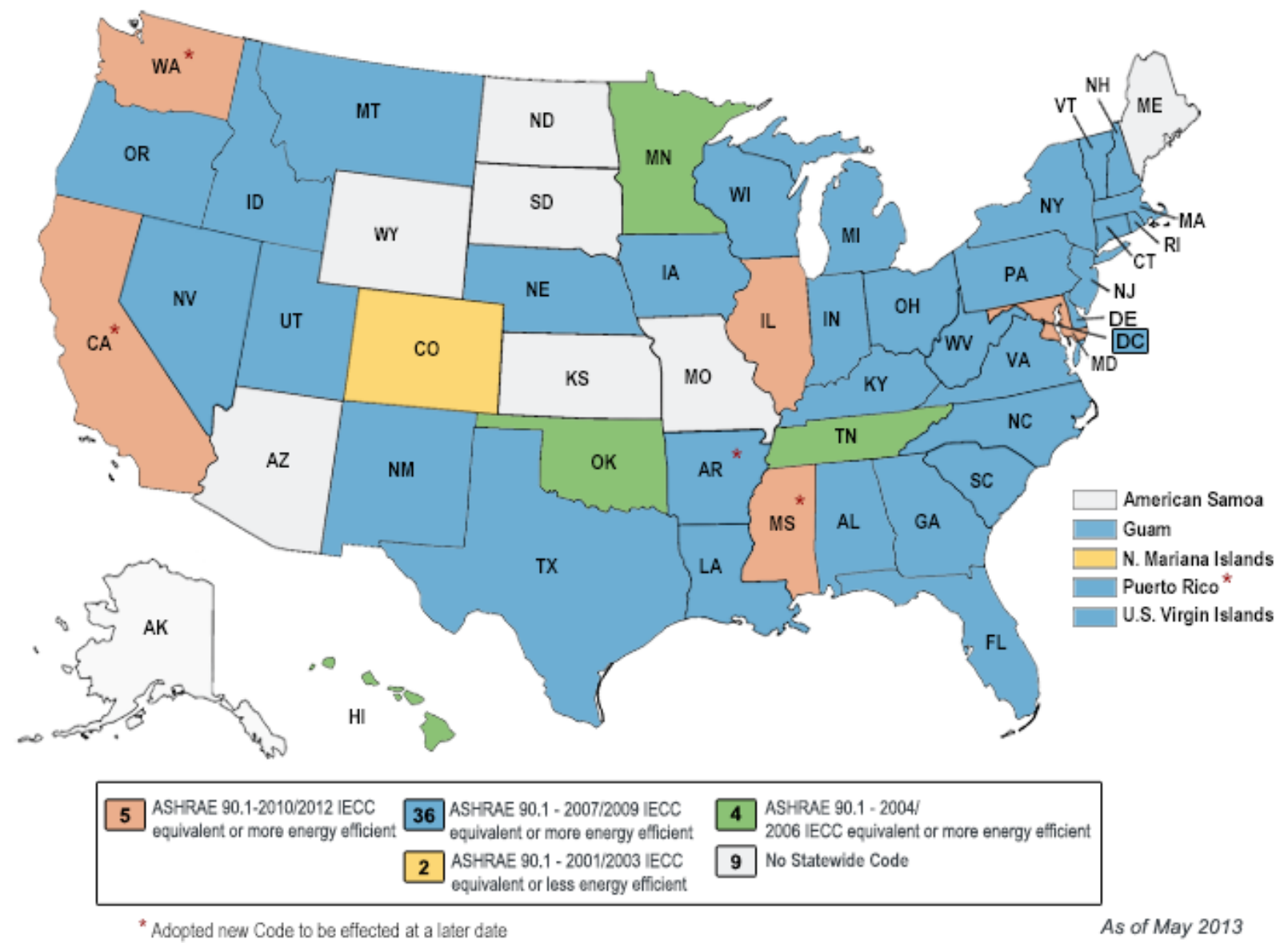

Figure 1.1. Current Commercial Building Energy Code Adoption Status

\subsection{Contents of the Report}

This report documents the approach and results for PNNL's analysis of the cost-effectiveness of 90.12010 compared to 90.1-2007. The cost-effectiveness analysis began with the energy savings analysis for development of 90.1-2010 which included energy model simulation using 16 prototype models in 17 climate locations. Six of the prototypes and five of the climate locations used for the savings analysis were selected to represent the building cost and energy and maintenance impacts of the changes in Standard 90.1 from 90.1-2007 to 90.1-2010. Chapter 2 provides an overview of the selected prototypes and climate locations utilized for this analysis.

The cost estimate for the cost-effectiveness analysis was started by describing each cost item sufficiently to provide the cost estimates. The cost items are developed based on addenda to 90.1-2007 incorporated into 90.1-2010 that were modeled for energy savings. Chapter 3 describes these addenda.

The cost estimate methodology and cost items are described in chapter 4, with a summary of the incremental costs is provided. An expanded summary of the incremental costs is also included in Appendix B of this report. The complete cost estimates are available in a spreadsheet Cost-effectiveness of ASHRAE Standard 90.1-2010-Cost Estimate (PNNL 2013). The cost-effectiveness analysis methodology and results are presented in Chapter 5. 
The report has three appendixes. Appendix A includes prototype building descriptions for the six prototypes considered, reprinted from Energy and Cost Savings Analysis of ASHRAE Standard 90.1-2010. Appendix B includes a summary of incremental cost estimate data. Appendix C includes the energy analysis results for 90.1-2010 compared to 90.1-2007. 


\subsection{Building Prototypes and Climate Locations}

PNNL provided technical support during the development of 90.1-2010 including building energy simulation to determine the energy savings between 90.1-2004 and 90.1-2010. PNNL developed 16 prototype building models which were simulated in 17 climate locations. This simulation process, referred to as the Progress Indicator (PI), resulted in periodic updates and a final assessment of the energy savings potential of changes in Standard 90.1 throughout the 90.1-2010 development cycle. These prototype models, their development, and the climate locations were described in detail in Energy and Cost Savings Analysis of ASHRAE Standard 90.1-2010. PNNL selected six of these prototype buildings simulated in five of the climate locations for the cost-effectiveness analysis to represent most of the energy and cost impacts of the changes in Standard 90.1. A subset of prototypes and climate locations was used to control the resources needed to complete the study.

\subsection{Selection of Prototype Buildings}

The six prototype models selected for the cost-effectiveness analysis are shown highlighted with all 16 prototypes in Table 2.1. These six prototypes were chosen for this analysis based on the following:

- They capture 38 of the 41 addenda to 90.1-2007 that were included in PNNL's simulation of energy savings for 90.1-2010. The remaining three addenda affect building systems that were not included in the prototypes.

- The prototypes include nearly all of the HVAC systems that were simulated in the 16 prototype models.

- The six prototypes chosen represent principal building activities that account for $81 \%$ of the new construction by floor area accounted for in the full suite of 16 prototypes.

Table 2.2 shows the six prototypes and their corresponding HVAC systems. 
Table 2.1. Prototype Buildings

\begin{tabular}{llc}
\hline \multicolumn{1}{c}{ Principal Building Activity } & \multicolumn{1}{c}{ Building Prototype } & Included in Current Analysis \\
\hline Office & Small Office & Yes \\
& Medium Office & No \\
& Large Office & Yes \\
Mercantile & Standalone Retail & Yes \\
& Strip Mall & No \\
Education & Primary School & Yes \\
& Secondary School & No \\
Healthcare & Outpatient Healthcare & No \\
& Hospital & No \\
Lodging & Small Hotel & Yes \\
& Large Hotel & No \\
Warehouse & Warehouse (non-refrigerated) & No \\
Food Service & Quick-service Restaurant & No \\
& Full-service Restaurant & No \\
Apartment & Mid-rise Apartment & Yes \\
& High-rise Apartment & No \\
\hline
\end{tabular}

Table 2.2. HVAC Systems in Selected Prototypes

\begin{tabular}{llll}
\hline \multicolumn{1}{c}{ Building Prototype } & \multicolumn{1}{c}{ Heating } & \multicolumn{1}{c}{ Cooling } & \multicolumn{1}{c}{ Primary System } \\
\hline Small Office & Heat Pump & Unitary direct expansion (DX) & Packaged constant air volume (CAV) \\
\hline Large Office & Boiler & Chiller, cooling tower & Variable air volume (VAV) with reheat \\
Stand-alone Retail & Gas furnace & Unitary DX & Packaged CAV \\
\hline Primary School & $\begin{array}{l}\text { Boiler/Gas } \\
\text { furnace }\end{array}$ & Unitary DX & Packaged VAV \\
Small Hotel & Electricity & DX & $\begin{array}{l}\text { Packaged terminal air conditioner } \\
\text { (PTAC) }\end{array}$ \\
\hline Mid-rise Apartment & Gas & DX & Split DX system \\
\hline
\end{tabular}

\subsection{Selection of Climate Locations}

As energy usage varies with climate, there are 8 climate zones used by ASHRAE for residential and commercial standards. These eight climate zones cover the entire United States, as shown in Figure 2.1 (Briggs et al. 2003). Climate zones are numbered from 1 to 8, from hottest to coldest categorized by cooling and heating degree days. The climate zones are further divided into climate subzones by moisture characteristics into moist, dry, and marine regions; for example, climate subzone 3A, a warm humid 
region, is part of the southern states. In total, there are 17 climate subzones. These climate zones and subzones may be mapped to locations outside the United States.

For the Standard 90.1 energy savings analysis, a specific climate location (city) is selected as a representative of each climate subzone. A set of 17 cities is used to represent the 17 climate conditions identified in Standard 90.1. Two of these cities are outside the United States, because the climate subzones they represent do not exist in the United States. Riyadh, Saudi Arabia, represents climate subzone 1B (very hot, dry) and Vancouver B.C., Canada, represents climate subzone 5C (cool, marine). The 17 cities representing the climate subzones are listed below with the five selected for the costeffectiveness analysis shown in italics. These five selected climate subzones cover most of the high population regions of the U.S and include 79\% of new construction by floor area (Thornton et al. 2011).

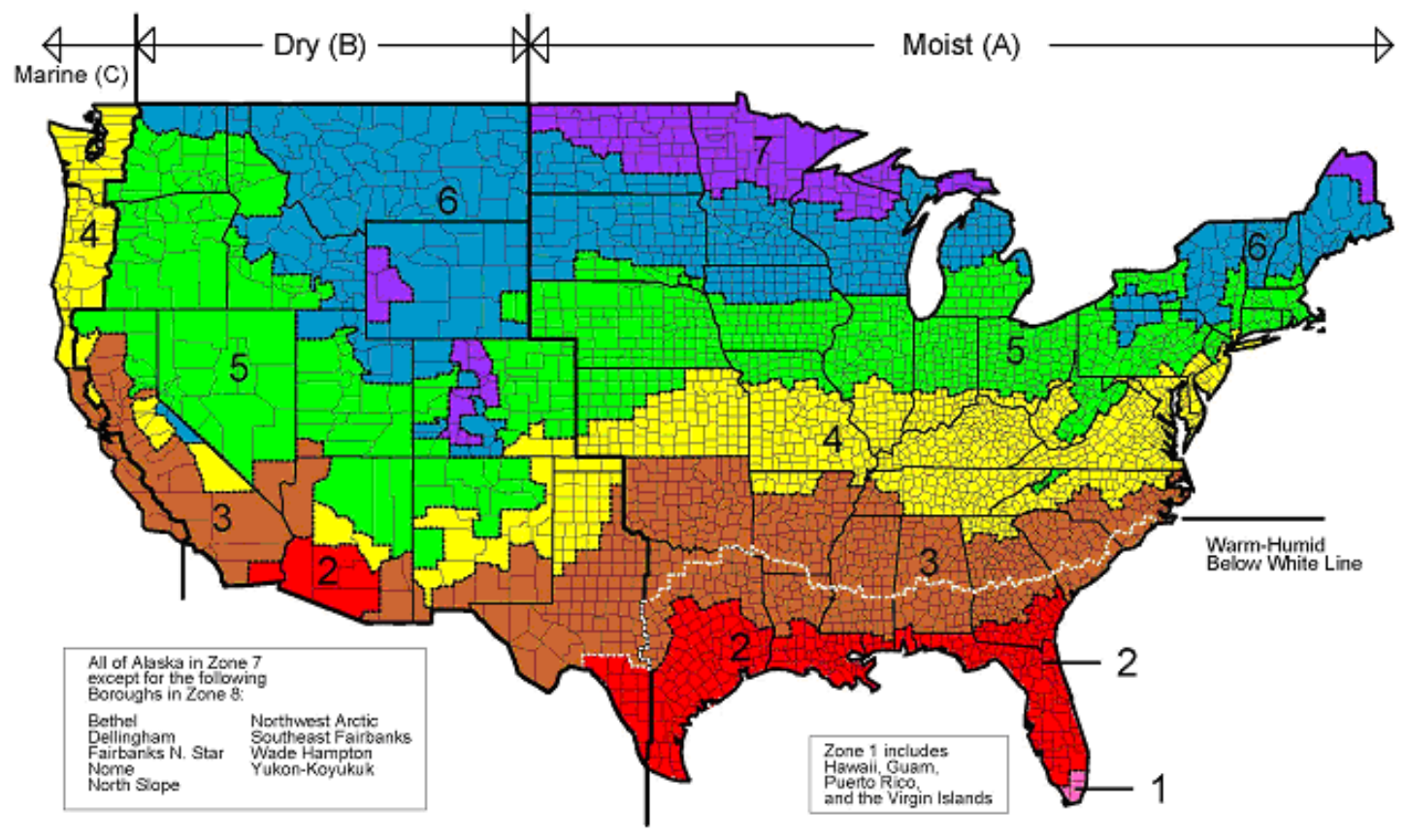

Figure 2.1. Climate Zone Map 
Table 2.3 Climate Locations by Climate Subzones

\begin{tabular}{lllc}
\hline $\begin{array}{c}\text { Climate } \\
\text { Zone }\end{array}$ & Climate Zone Type & \multicolumn{1}{c}{ Representative City } & $\begin{array}{c}\text { Included in Current } \\
\text { Analysis }\end{array}$ \\
\hline 1A & Very Hot, Humid & Miami, FL & No \\
\hline 1B & Very Hot, Dry & Riyadh, Saudi Arabia & No \\
2A & Hot, Humid & Houston, TX & Yes \\
\hline 2B & Hot, Dry & Phoenix, AR & No \\
3A & Warm, Humid & Memphis, TN & Yes \\
\hline 3B & Warm, Dry & El Paso, TX & Yes \\
\hline 3C & Warm, Marine & San Francisco, CA & No \\
\hline 4A & Mixed, Humid & Baltimore, MD & Yes \\
\hline 4B & Mixed, Dry & Albuquerque, NM & No \\
\hline 4C & Mixed, Marine & Salem, OR & No \\
\hline 5A & Cool, Humid & Chicago, IL & Yes \\
\hline 5B & Cool, Dry & Boise, ID & No \\
\hline 5C & Cool, Marine & Vancouver, B.C., Canada & No \\
\hline 6A & Cool, Humid & Burlington, VT & No \\
\hline 6B & Cold, Dry & Helena, MT & No \\
\hline 7 & Very Cold & Duluth, MN & No \\
\hline 8 & Subarctic & Fairbanks, AK & No \\
\hline
\end{tabular}

\subsection{Description of Selected Prototypes}

Table 2.3 provides a brief overview of the six selected prototypes. Energy and Cost Savings Analysis of ASHRAE Standard 90.1-2010 provides further information. Included in Appendix A are profiles of each of the selected prototypes reprinted from Energy and Cost Savings Analysis of ASHRAE Standard 90.1-2010. These six profiles and the similar profiles for the other ten prototypes were included with Energy and Cost Savings Analysis of ASHRAE Standard 90.1-2010Goal. The prototype Energy Plus models are available for download (DOE 2012c). 
Table 2.4. Overview of Six Selected Prototypes

\begin{tabular}{|c|c|c|c|c|c|c|c|c|c|c|c|c|}
\hline \multirow{2}{*}{$\begin{array}{l}\text { Building } \\
\text { Prototype }\end{array}$} & \multirow{2}{*}{$\begin{array}{l}\text { Floor } \\
\text { area } \\
\left(\mathrm{ft}^{2}\right)\end{array}$} & \multirow{2}{*}{$\begin{array}{c}\text { Number } \\
\text { of } \\
\text { Floors }\end{array}$} & \multirow{2}{*}{$\begin{array}{c}\text { Window } \\
\text { to Wall } \\
\text { Ratio } \\
\text { (WWR) }\end{array}$} & \multirow{2}{*}{$\begin{array}{l}\text { Floor- } \\
\text { to-Floor } \\
\text { Height } \\
\text { (ft) }\end{array}$} & \multirow[b]{2}{*}{ Roof } & \multirow{2}{*}{$\begin{array}{c}\text { Exterior } \\
\text { Wall }\end{array}$} & \multirow{2}{*}{$\begin{array}{c}\text { Occupancy } \\
\text { (people/ } \\
1000 \mathrm{ft}^{2} \text { ) }\end{array}$} & \multirow{2}{*}{$\begin{array}{c}\text { Plug } \\
\text { Loads } \\
\left(\mathrm{W} / \mathrm{ft}^{2}\right)\end{array}$} & \multicolumn{2}{|c|}{ Interior Lighting } & \multicolumn{2}{|c|}{ Exterior Lighting } \\
\hline & & & & & & & & & $\begin{array}{c}2007 \\
\left(\mathrm{~W} / \mathrm{ft}^{2}\right)\end{array}$ & $\begin{array}{c}2010 \\
\left(\mathrm{~W} / \mathrm{ft}^{2}\right)\end{array}$ & $\begin{array}{l}2007 \\
(\mathrm{~kW})\end{array}$ & $\begin{array}{l}2010 \\
(\mathrm{~kW})\end{array}$ \\
\hline $\begin{array}{l}\text { Small } \\
\text { Office }\end{array}$ & 5,500 & 1 & $15 \%$ & 10 & $\begin{array}{c}\text { Attic and } \\
\text { Other }\end{array}$ & $\begin{array}{l}\text { Wood } \\
\text { Framed }\end{array}$ & 5.6 & 0.63 & 1.00 & 0.92 & 1.54 & 0.93 \\
\hline $\begin{array}{l}\text { Large } \\
\text { Office }\end{array}$ & $\begin{array}{l}498,6 \\
40\end{array}$ & $12^{1}$ & $40 \%$ & 13 & $\begin{array}{c}\text { Insulation } \\
\text { above } \\
\text { deck }\end{array}$ & Mass & 5.0 & 0.73 & 1.00 & 0.93 & 60.2 & 53.7 \\
\hline $\begin{array}{l}\text { Standalone } \\
\text { Retail }\end{array}$ & $\begin{array}{c}24,69 \\
0\end{array}$ & 1 & $7 \%$ & 20 & $\begin{array}{c}\text { Insulation } \\
\text { above } \\
\text { deck }\end{array}$ & Mass & 15.0 & 0.50 & 1.55 & 1.54 & 4.33 & 2.80 \\
\hline $\begin{array}{l}\text { Primary } \\
\text { School }\end{array}$ & $\begin{array}{c}73,97 \\
0\end{array}$ & 1 & $35 \%$ & 13 & $\begin{array}{c}\text { Insulation } \\
\text { above } \\
\text { deck }\end{array}$ & $\begin{array}{c}\text { Steel } \\
\text { Framed }\end{array}$ & 20.0 & $1.00^{3}$ & 1.19 & 1.05 & 5.22 & 3.40 \\
\hline $\begin{array}{l}\text { Small } \\
\text { Hotel }\end{array}$ & $\begin{array}{c}43,21 \\
0\end{array}$ & 4 & $11 \%$ & $\begin{array}{c}9 \\
11^{2}\end{array}$ & $\begin{array}{c}\text { Insulation } \\
\text { above } \\
\text { deck }\end{array}$ & $\begin{array}{c}\text { Steel } \\
\text { Framed }\end{array}$ & 6.0 & $0.95^{3}$ & 0.97 & 0.96 & 12.6 & 11.0 \\
\hline $\begin{array}{l}\text { Mid-rise } \\
\text { Apartment }\end{array}$ & $\begin{array}{c}33,74 \\
0\end{array}$ & 4 & $15 \%$ & 10 & $\begin{array}{c}\text { Insulation } \\
\text { above } \\
\text { deck }\end{array}$ & $\begin{array}{c}\text { Steel } \\
\text { Framed }\end{array}$ & 2.3 & 0.56 & 0.40 & 0.39 & 4.42 & 2.39 \\
\hline
\end{tabular}

\footnotetext{
${ }^{1}$ These buildings also include a basement which is not included in the number of floors

${ }^{2}$ First floor only

${ }^{3}$ Excludes any kitchen and or laundry electrical equipment
} 


\subsection{Cost Estimate Items from 90.1-2007 Addenda}

The number of addenda to 90.1-2007 approved during the three-year Standard 90.1 development cycle was unprecedented compared with previous updates to Standard 90.1. 90.1-2010 incorporated 109 approved addenda to 90.1-2007. In contrast, the last three updates of Standard 90.1 to 2001, 2004 and 2007 editions generated 34, 32 and 44 approved addenda, respectively.

Of the 109 addenda included in 90.1-2010, 41 were considered to have quantifiable energy savings, and were modeled in the 90.1-2010 energy savings analysis. The other addenda do not have quantifiable savings, had no savings, or do not affect the sections of 90.1 that directly impact building energy usage. The addenda were described in more detail in Energy and Cost Savings Analysis of ASHRAE Standard 90.1-2010.

Of the 41 addenda with quantified savings, 38 were modeled in the six prototypes being used for the cost estimate. The remaining three addenda affect building systems that were not included in the prototypes. Most of the addenda that were included in the cost estimate affect elements of the building HVAC and lighting systems. There were no addenda to 90.1-2007 included in 90.1-2010 for Chapter 7 Service Water Heating. Figure 3.1 shows the breakdown of addenda captured in the cost estimate by chapter of the standard.

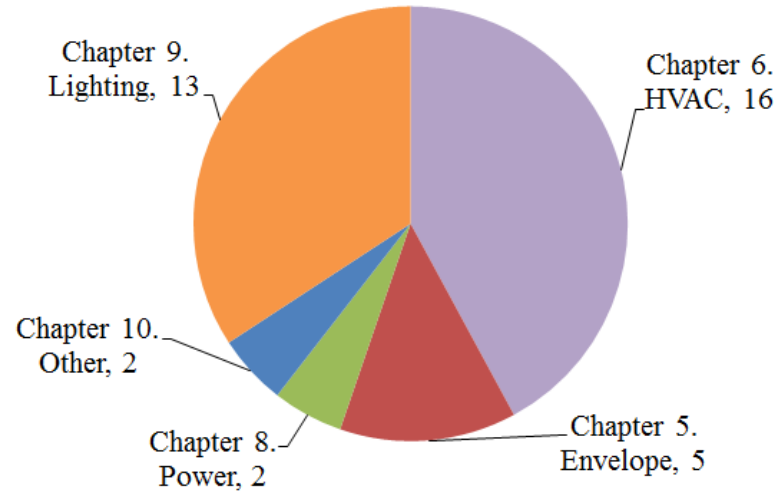

Figure 3.1. Quantity of Addenda Included in the Cost Estimate by Standard 90.1 Chapter

Table 3.1 provides a listing and a brief description of all he addenda included in the cost estimates, and the prototypes to which they apply. The changes due to these addenda are described in Chapter 4 of this report. Costs for HVAC were separated out for HVAC systems which deliver cooling and heating to the building spaces and for the central plant equipment which provides chilled and hot water to HVAC systems. Plant equipment is only included in the large office and primary school prototypes. Costs estimates include adjustments in HVAC system capacities due to the other changes in the models, particularly reduced heat gains from lighting power reductions.

Throughout this report, each addendum to Standard 90.1 is named according to a convention that begins with 90.1-07, followed by the letter identifier of the addendum (e.g., 90.1-07cb). 
Table 3.1. 90.1-2007 Addenda Cost Items

\begin{tabular}{|c|c|c|c|c|c|c|c|}
\hline $\begin{array}{l}90.1 \text { Addenda and Other } \\
\text { Cost Items }\end{array}$ & Description & 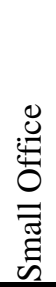 & 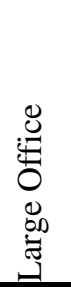 & 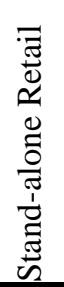 & 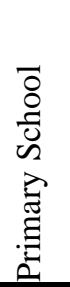 & 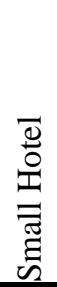 & 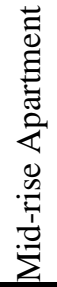 \\
\hline \multicolumn{8}{|c|}{ Standard 90.1 Chapter 6 Heating Ventilating and Air Conditioning } \\
\hline $\begin{array}{l}\text { HVAC } \\
\text { System Capacity } \\
\text { Changes }\end{array}$ & $\begin{array}{l}\text { Changes in system equipment and ductwork capacity due to } \\
\text { HVAC load differences.. }\end{array}$ & $\mathrm{X}$ & $\mathrm{X}$ & $\mathrm{X}$ & $\mathrm{X}$ & $\mathrm{X}$ & \\
\hline 90.1-07bw & PTAC and PTHP efficiency & & & & & $\mathrm{X}$ & \\
\hline 90.1-07n and ca & Single zone system fan speed control & & & $\mathrm{X}$ & $X$ & & \\
\hline $90.1-07 h$ & VAV dual minimum damper control & & $\mathrm{X}$ & & $\mathrm{X}$ & & \\
\hline 90.1-07bh & VAV supply air temperature reset & & $\mathrm{X}$ & & $\mathrm{X}$ & & \\
\hline $90.1-07 \mathrm{ck}$ & VAV system ventilation optimization & & $\mathrm{X}$ & & $\mathrm{X}$ & & \\
\hline $90.1-07 \mathrm{cb}$ & Automatic dampers & $\mathrm{X}$ & & $\mathrm{X}$ & $\mathrm{X}$ & & \\
\hline 90.1-07су & Economizers & $\mathrm{X}$ & $\mathrm{X}$ & $\mathrm{X}$ & $\mathrm{X}$ & $\mathrm{X}$ & \\
\hline 90.1-07e and dj & Energy recovery & & $\mathrm{X}$ & $\mathrm{X}$ & $\mathrm{X}$ & & \\
\hline $90.1-07 a x$ & Kitchen hood systems & & & & $\mathrm{X}$ & & \\
\hline $\begin{array}{l}\text { HVAC } \\
\text { Plant Capacity Changes }\end{array}$ & $\begin{array}{l}\text { Changes in plant equipment and piping capacity due to load } \\
\text { differences }\end{array}$ & & $\mathrm{X}$ & & $\mathrm{X}$ & & \\
\hline $90.1-07 \mathrm{~m}$ & Chiller efficiency & & $\mathrm{X}$ & & & & \\
\hline $90.1-07 u$ & Cooling tower efficiency & & $\mathrm{X}$ & & & & \\
\hline 90.1-07af and cc & $\begin{array}{l}\text { Chilled water and condenser water pipe sizing relative to } \\
\text { flow }\end{array}$ & & $\mathrm{X}$ & & & & \\
\hline 90.1-07ak & Pump speed and pressure differential control & & $\mathrm{X}$ & & & & \\
\hline \multirow[t]{2}{*}{ 90.1-07aj } & Motor efficiency & $\mathrm{X}$ & $\mathrm{X}$ & $\mathrm{X}$ & $\mathrm{X}$ & $\mathrm{X}$ & \\
\hline & Standard 90.1 Chapter 9 Lighting & & & & & & \\
\hline 90.1-07by & General interior lighting power density (LPD) & $\mathrm{X}$ & $\mathrm{X}$ & $\mathrm{X}$ & $\mathrm{X}$ & $\mathrm{X}$ & $\mathrm{X}$ \\
\hline 90.1-07de & Lobby LPD & $\mathrm{X}$ & $\mathrm{X}$ & $\mathrm{X}$ & $\mathrm{X}$ & $\mathrm{X}$ & \\
\hline $90.1-07 x$ & $\begin{array}{l}\text { Automatic lighting shutoff required, occupancy sensors } \\
\text { option selected for prototypes }\end{array}$ & $\mathrm{X}$ & $\mathrm{X}$ & $\mathrm{X}$ & $X$ & $\mathrm{X}$ & $\mathrm{X}$ \\
\hline 90.1-07аa & $\begin{array}{l}\text { Automatic lighting shutoff, type of occupancy sensor } \\
\text { control required to be manual on/off rather than automatic } \\
\text { on/off for some applications }\end{array}$ & $\mathrm{X}$ & $\mathrm{X}$ & $\mathrm{X}$ & $\mathrm{X}$ & $\mathrm{X}$ & $\mathrm{X}$ \\
\hline $90.1-07 \mathrm{cf}$ & Stairwell lighting control & & $\mathrm{X}$ & $\mathrm{X}$ & $\mathrm{X}$ & $\mathrm{X}$ & $\mathrm{X}$ \\
\hline 90.1-07aw & Hotel bathroom lighting control & & & & & $\mathrm{X}$ & \\
\hline 90.1-07d and ab & Daylighting control, toplit areas & & $\mathrm{X}$ & $\mathrm{X}$ & $\mathrm{X}$ & & \\
\hline 90.1-07ab and ct & Daylighting control, sidelit areas & $\mathrm{X}$ & $X$ & & $\mathrm{X}$ & $\mathrm{X}$ & \\
\hline $90.1-07 i$ & External lighting power & $\mathrm{X}$ & $\mathrm{X}$ & $\mathrm{X}$ & $\mathrm{X}$ & $\mathrm{X}$ & $\mathrm{X}$ \\
\hline 90.1-07cd & Exterior lighting control & $\mathrm{X}$ & $\mathrm{X}$ & $\mathrm{X}$ & $\mathrm{X}$ & & \\
\hline
\end{tabular}




\begin{tabular}{|c|c|c|c|c|c|c|c|}
\hline $\begin{array}{l}90.1 \text { Addenda and Other } \\
\text { Cost Items }\end{array}$ & Description & 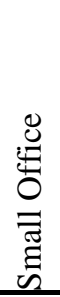 & 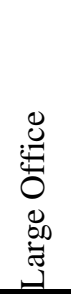 & 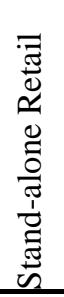 & 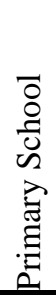 & 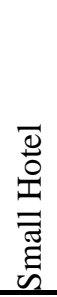 & 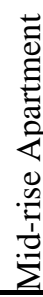 \\
\hline \multicolumn{8}{|c|}{ Standard 90.1 Chapter 5 Envelope } \\
\hline $90.1-07 f$ & Roof reflectance & $\mathrm{X}$ & $\mathrm{X}$ & $\mathrm{X}$ & $\mathrm{X}$ & $\mathrm{X}$ & $\mathrm{X}$ \\
\hline $90.1-07 q$ & Vestibules & $\mathrm{X}$ & & & & & \\
\hline 90.1-07am & Window and door air leakage & $\mathrm{X}$ & $\mathrm{X}$ & $\mathrm{X}$ & $\mathrm{X}$ & $\mathrm{X}$ & $\mathrm{X}$ \\
\hline 90.1-07bf & Air barrier, air leakage & $\mathrm{X}$ & $\mathrm{X}$ & $\mathrm{X}$ & $\mathrm{X}$ & $\mathrm{X}$ & $\mathrm{X}$ \\
\hline 90.1-07bn & Fenestration orientation & & & & & $\mathrm{X}$ & \\
\hline 90.1-07al and dd & Skylights required & & & & $\mathrm{X}$ & & \\
\hline \multicolumn{8}{|c|}{ Standard 90.1 Chapter 8 Power and Chapter 10 Other } \\
\hline $90.1-070$ & Transformer efficiency & & $\mathrm{X}$ & & $\mathrm{X}$ & & \\
\hline 90.1-07bs & Receptacle on/off control & $\mathrm{X}$ & $\mathrm{X}$ & $\mathrm{X}$ & $\mathrm{X}$ & $\mathrm{X}$ & $\mathrm{X}$ \\
\hline $90.1-07 \mathrm{df}$ & Elevator lighting and ventilation & & $\mathrm{X}$ & & & $\mathrm{X}$ & $\mathrm{X}$ \\
\hline
\end{tabular}




\subsection{Incremental Cost Estimates}

This Chapter describes the approach used for developing the incremental cost estimates, the description of the individual cost estimates, and a summary of the total incremental cost estimate results. The incremental cost estimates were developed for the purpose of evaluating the cost-effectiveness of the changes between 90.1-2007 and 90.1-2010. Costs for actual building projects should be developed separately and DOE and PNNL do not provide any support or responsibility for their use for any other purpose.

\subsection{Incremental Cost Estimate Approach}

The first step in developing the incremental cost estimates was to define the items to be estimated, such as specific pieces of equipment and their installation. Part of the cost item information was extracted from the prototype building energy model inputs and outputs, and from Energy and Cost Savings Analysis of ASHRAE Standard 90.1-2010. In some cases, the prototype models do not include sufficient design details to provide the basis for cost estimates and additional details were developed to support the cost estimating effort. These are described in Section 4.2 of this report along with the costs. A summary of the incremental costs is included in Appendix B of this report. The cost estimates are available in the spreadsheet Cost-effectiveness of ASHRAE Standard 90.1-2010-Cost Estimate (PNNL 2013). The second step in the cost estimate began by defining the types of costs to be collected. The cost estimates covered incremental costs for material, labor, construction equipment, commissioning, maintenance, and overhead and profit (OH\&P). These costs were estimated for both for initial construction as well as, for replacing equipment at the end of its useful life.

The third step was to produce the cost estimates. PNNL worked with a cost estimating consulting firm, a mechanical, electrical and plumbing (MEP) consulting engineering firm, and a daylighting consultant, as well as utilizing its own expertise to develop cost information. RS Means cost handbooks were used extensively and provide nearly all of the labor costs (RS Means 2012A, 2012B, 2012c. Members of the 90.1 SSPC mechanical, lighting, and envelope subcommittees also provided cost information. New and replacement cost estimates were intended to approximate what a general contractor typically submits to the developer or owner and includes subcontractor and contractor costs and markups. Maintenance costs were intended to reflect what a maintenance firm would charge. Once initial costs were developed, a technical review was conducted by members of the 90.1 lighting and mechanical subcommittees, and PNNL internal sources.

\subsubsection{Source of Cost Estimates}

Developing the costs required the expertise of professional cost estimators. Table 4.1 includes a description of all sources of cost estimates by category of costs (e.g. HVAC). HVAC cost items were developed primarily by two consulting firms. The cost estimating firm provided the cost for HVAC systems including packaged DX and chilled and hot water systems as well as central plant equipment. The engineering consulting firm provided most of the ductwork and piping costs, and most of the controls items. Costs were requested for several controls items such as supply air temperature reset from both sources for comparison. SSPC 90.1 members were also consulted for several items including cooling 
tower efficiency, and VAV system controls. RS Means cost data was used for estimating labor costs by both consultants (RS Means 2012A).

For lighting and some HVAC items, PNNL developed costs. Resources used included the chairman of the 90.1 LSC, online sources and an outside consultant for daylighting costs. In addition to these summary tables, specific sources such as the name of product suppliers are included in the cost estimate spreadsheet (PNNL 2013).

Table 4.1. Sources of Cost Estimates by Cost Category

\begin{tabular}{|c|c|}
\hline Cost Category & Source \\
\hline $\begin{array}{l}\text { HVAC } \\
\text { Motors included in this category }\end{array}$ & $\begin{array}{l}\text { Cost estimator used quotes from suppliers and manufacturers, online } \\
\text { sources, and their own experience. }\end{array}$ \\
\hline $\begin{array}{l}\text { HVAC } \\
\text { Ductwork, piping, selected controls } \\
\text { items }\end{array}$ & $\begin{array}{l}\text { MEP consulting engineers provided ductwork and plumbing costs based } \\
\text { on one-line diagrams they created, and the model outputs, including } \\
\text { system airflows, capacity and other factors, and provided detailed costs } \\
\text { by duct and piping components using RS Means } 2012 \text { Mechanical Cost } \\
\text { Data. The MEP consulting engineers also provided costs for several } \\
\text { control items. }\end{array}$ \\
\hline $\begin{array}{l}\text { HVAC } \\
\text { Selected items }\end{array}$ & $\begin{array}{l}\text { PNNL utilized staff expertise and experience supplemented with online } \\
\text { sources. }\end{array}$ \\
\hline $\begin{array}{l}\text { Lighting } \\
\text { Interior lighting power allowance } \\
\text { and occupancy sensors }\end{array}$ & $\begin{array}{l}\text { PNNL staff with oversight from chairman of } 90.1 \text { LSC. Product catalogs } \\
\text { were used for consistency with some other online sources where needed. }\end{array}$ \\
\hline $\begin{array}{l}\text { Lighting } \\
\text { Daylighting }\end{array}$ & PNNL staff and daylighting consulting firm. \\
\hline $\begin{array}{l}\text { Lighting } \\
\text { Exterior lighting }\end{array}$ & $\begin{array}{l}\text { PNNL staff lighting designer involved with multiple exterior lighting } \\
\text { initiatives particularly for parking lot lighting. }\end{array}$ \\
\hline Maintenance & $\begin{array}{l}\text { From the originator of the other costs from the affected items, or PNNL } \\
\text { staff expertise. }\end{array}$ \\
\hline Commissioning & Cost estimator, MEP consulting engineers, or PNNL staff expertise. \\
\hline Labor & $\begin{array}{l}\text { RS Means } 2012 \text { Mechanical, Electrical and Construction Cost Data and } \\
\text { Electrical Cost Data, the MEP consulting engineers for commissioning } \\
\text { rate. }\end{array}$ \\
\hline Replacement life & $\begin{array}{l}\text { Lighting equipment including lamps, and ballasts from product catalogs. } \\
\text { Mechanical from } 90.1 \text { Mechanical Subcommittee protocol for cost } \\
\text { analysis. }\end{array}$ \\
\hline
\end{tabular}

\subsubsection{Cost Parameters}

Several general parameters applied to all of the cost estimates. These items included new construction material and labor cost adjustments, a replacement labor hour adjustment, replacement material and labor cost adjustments, and a project cost adjustment. These parameters are described in Table 4.2.

Costs were not adjusted for climate locations. The climate location results were intended to represent an entire climate subzone even though climate data for a particular city is used for modeling purposes. Costs will vary significantly between a range of urban, suburban and rural areas within the five selected climate locations which cross multiple states. Costs can be adjusted for specific cities based on city cost index adjustments from RS Means or other sources. 
Table 4.2. Cost Estimate Adjustment Parameters

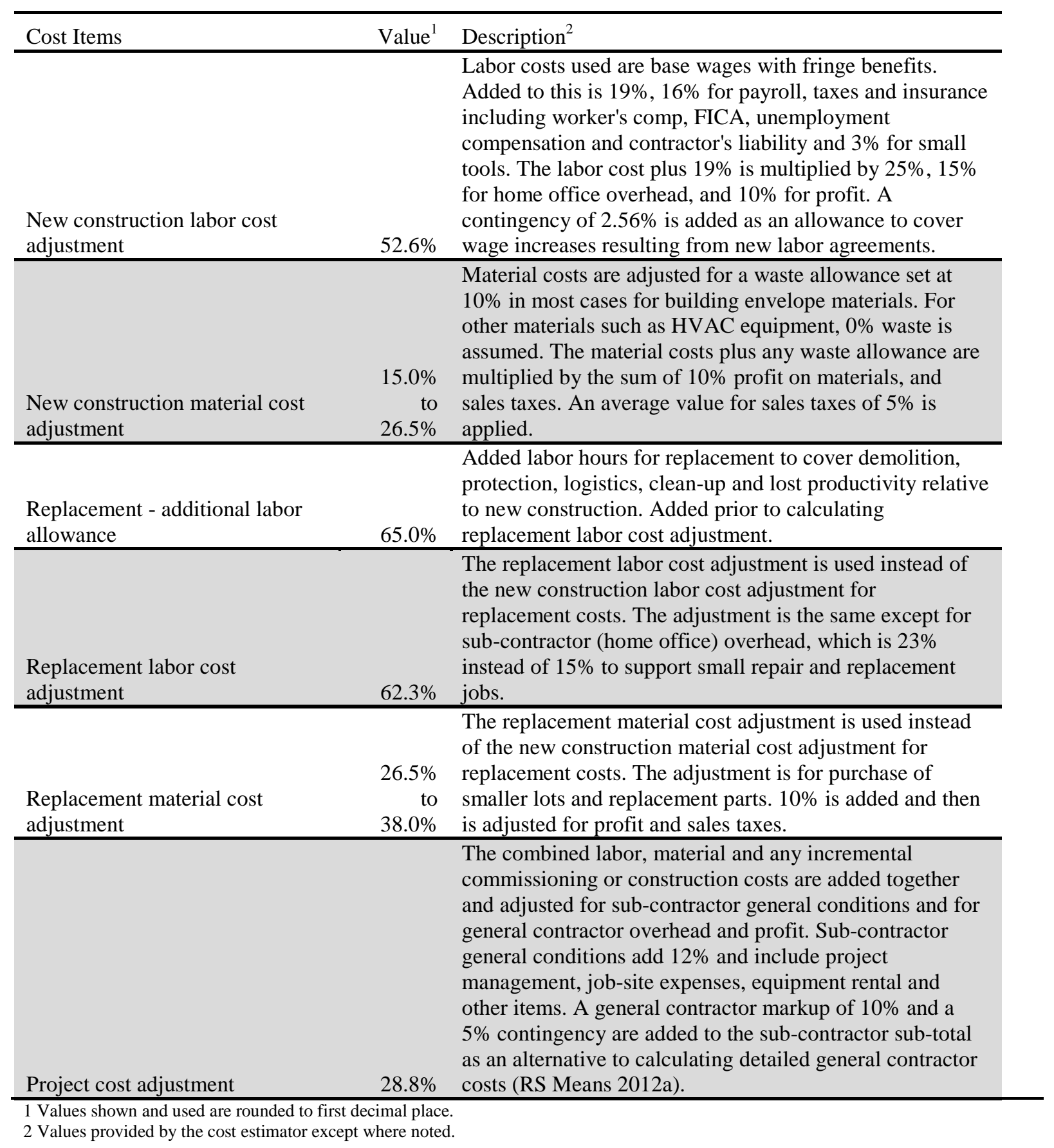

\subsubsection{Cost Estimate Spreadsheet Workbook}

The cost spreadsheet (PNNL 2013) is organized in the following sections, some with multiple worksheets, each highlighted with a different colored tab described in the introduction:

1) Introduction

2) HVAC cost estimates 
3) Lighting cost estimates
a. Interior lighting power density
b. Interior lighting occupancy related controls
c. Daylighting controls
d. Exterior lighting

4) Envelope Power and Other cost estimates

5) Cost Estimate Summaries

Within the three cost estimate sections, there are several types of cost worksheets. Component costs (labeled with "comp” in the worksheet name) are the individual cost items not assigned to the particular prototype, such as the cost for a $400 \mathrm{~W}$ metal halide floodlight lamp. Prototype costs (labeled with "proto" in the worksheet name) are the assignment of component costs to the applicable prototypes and climate locations. For HVAC costs, which may vary significantly by climate locations, there is one cost sheet for each prototype. The Interior Lighting LPD section includes an additional worksheet which assigns costs to lighting space types which are then assigned to the prototypes. Envelope Power and Other combines component and prototype costs in one sheet. Results totals for new construction, maintenance and replacement over 40 years are shown for each prototype and climate location in the prototype cost worksheets.

There are two Cost Estimate Summary sheets. The first summary worksheet has costs with replacements for 29 years, with the residual value of items with useful lives that do not fit evenly in 30 years or that have a longer than 30 year life year included in year 30 . The second summary worksheet extends the replacements for 39 years, and includes residual values in year 40 . Residual values are discussed in Section 5.1.1.

\subsection{Cost Estimate Descriptions}

Cost estimate items are tied to each specific 90.1-2007 addendum as identified in the descriptions of the cost items in this section and as listed in Table 3.1. The remaining portion of this section provides more detailed descriptions of the additional information developed to establish the basis for estimating costs, as well as information about the cost estimates themselves. These are organized by major sections for HVAC, lighting, and power, envelope and other equipment.

\subsubsection{Heating, Ventilating and Air Conditioning}

A substantial part of the HVAC system cost estimates were tied to changes in system and plant equipment capacity between the 90.1-2007 and 90.1-2010 for corresponding prototype and climate location models. Costs for capacity changes for HVAC system and plant equipment are described together in Section 4.2.1.1 of this report. 
The other cost estimates were tied to specific 90.1-2007 addenda. There were a cluster of addenda that were targeted at variable air volume (VAV) systems to address the energy usage of these systems related to ventilation effectiveness and reheat. Changes in requirements for outdoor air damper control and economizers had a broad impact on HVAC systems in most prototypes. Plant equipment addenda primarily affected the Large Office, with heating related impacts on the primary school which includes VAV systems with hot water reheat. There was a net decrease in HVAC costs in some cases due to the decrease in capacity, airflow, and water flow offsetting increased costs from addenda that added costs.

\subsubsection{HVAC System and Plant Equipment Capacity Changes}

Location in 90.1-2010: $\quad$ Not covered by a specific section in 90.1-2010

Addenda: $\quad$ None, but affected by all addenda that affect space HVAC loads such as lighting power density, 90.1-07by

Prototypes Affected: All

Costs were estimated to address changes in HVAC system and plant capacity between the 90.1-2007 and 90.1-2010 prototype models. The primary sources of capacity changes were from reductions in heating and cooling loads due to changes in lighting power and controls, energy recovery, infiltration, automatic outdoor damper control during morning warm-up, and roof reflectance.

The HVAC capacity changes are a substantial part of the HVAC cost differences. The costs are developed for a range of equipment sizes corresponding to the models. The HVAC capacity related equipment costs are the same for the same capacity equipment for 90.1-2007 and 90.1-2010 in the component cost worksheet. The costs differ in the prototype specific cost worksheets based on the capacity of the equipment extracted from the simulation models. Ductwork and piping cost results were calculated separately as a total cost for each combination of prototype and climate location, and values for 90.1-2007 and 90.1-2010 are different based on system airflow, or water flow.

In most cases, the cost estimator provided equipment costs from two manufacturers and the average was used. Equipment costs were compared with RS Means 2012 when possible and were usually similar to the costs provided by the cost estimator. An exception was the RS Means AHU equipment costs which were substantially higher than the cost estimator values. Review of the air handler unit costs by the cost estimator with the suppliers who provided these costs determined that the costs were accurate. Therefore the lower costs from the consultant and suppliers were used rather than the RS Means values for this one item.

The component costs were assigned to the prototypes based on the capacity (e.g. tons of cooling, outdoor airflow, or other measure appropriate to the equipment) of the equipment in the model. A range of equipment costs for different sizes of a type of equipment were collected.

The costs associated with changes to 90.1 Chapter 10 requirements for motor efficiency were also included with the HVAC load change costs because motor size varied with the fan and pump sizes. Piping and ductwork costs (and some controls costs) were developed by the MEP consulting engineers. This effort included developing schematic level single line representative layouts of the ductwork and piping for each prototype. Detailed costs for these at the level of duct and pipe size and length, and all fittings 
were developed based on the component by component costs from RS Means 2012. For some prototypes and climates, the differences in capacity were so close that there were very limited cost differences and separate costs were not developed. This is why some of these costs are identical to each other between climate locations for a given prototype.

For example, Figure 4.1 provides an exterior view of the Small Office prototype and an image of the air distribution layout provided by the MEP consulting engineers. Table 4.3 shows an example of the level of duct work detail developed. Costs for each air distribution element were estimated (primarily from RS Means 2012) and then summed up. For example, for the Baltimore climate location the 90.12007 material cost is $\$ 5,692$ and the $90.1-2010$ cost is $\$ 5,479$.
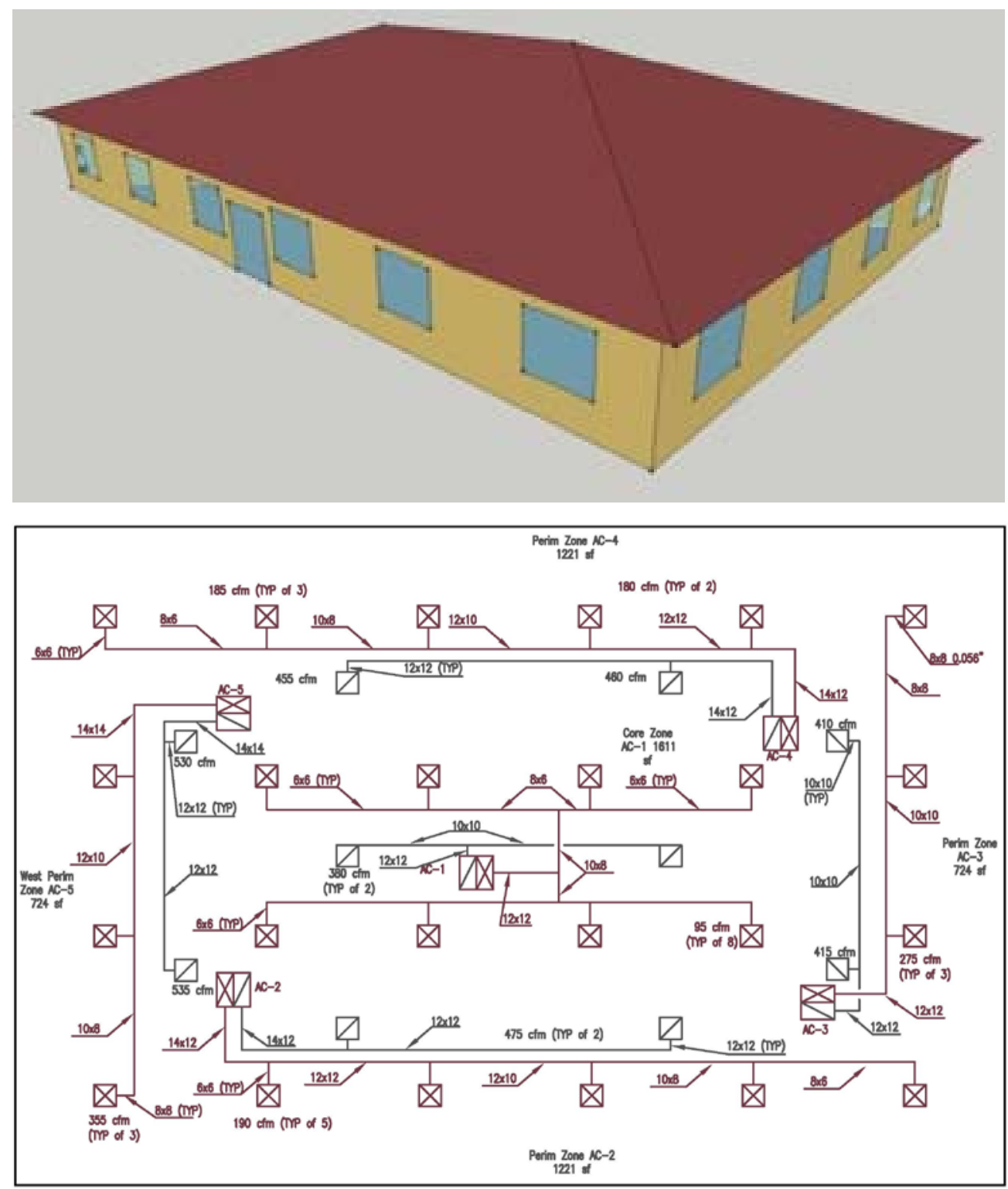

Figure 4.1. Small Office Air Distribution System 
Table 4.3. Small Office Duct Details for One HVAC System

\begin{tabular}{|c|c|c|c|c|c|c|c|c|}
\hline Description & Multiplier & $\begin{array}{l}\text { Depth } \\
\text { (in.) }\end{array}$ & $\begin{array}{l}\text { Width } \\
\text { (in.) }\end{array}$ & $\begin{array}{l}\text { Area } \\
\left(\mathrm{ft}^{2}\right)\end{array}$ & $\begin{array}{l}\text { Duct } \\
\text { Length } \\
\text { (ft.) }\end{array}$ & $\begin{array}{l}\text { Depth + } \\
\text { Width }\end{array}$ & $\begin{array}{c}\text { Duct } \\
\text { Weight } \\
\text { (lb.) }\end{array}$ & $\begin{array}{l}\text { Item } \\
\text { Qty. }\end{array}$ \\
\hline \multicolumn{9}{|l|}{ Supply Side } \\
\hline 12x12 Duct & 1 & 12 & 12 & 1.00 & 6 & 24 & 34.8 & \\
\hline SR5-14 Dovetail WYE & 1 & 12 & 10 & 0.83 & & 22 & & 32.9 \\
\hline ER4-2, Transition, Pyramidal & 1 & 10 & 8 & 0.56 & & 18 & & 17.3 \\
\hline 10x8 Duct & 2 & 10 & 8 & 0.56 & 4 & 18 & 34.7 & \\
\hline SR5-14 Dovetail WYE & 1 & 8 & 6 & 0.33 & & 14 & & 20.9 \\
\hline 8x6 Duct & 4 & 8 & 6 & 0.33 & 7 & 14 & 85.5 & \\
\hline SR5-13 Tee, 45 degrees (Qs) & 4 & 6 & 6 & 0.25 & & 12 & & 15.2 \\
\hline SR5-13 Tee, 45 degrees (Qb) & 1 & 6 & 6 & 0.25 & & 12 & & \\
\hline $\begin{array}{l}\text { 6x6 Duct } \\
\text { CR3-14 Elbow (1.5" Vane }\end{array}$ & 4 & 6 & 6 & 0.25 & 20 & 12 & 182.4 & \\
\hline Spc) & 4 & 6 & 6 & 0.25 & & 12 & & 4.0 \\
\hline 6x6 Duct & 8 & 6 & 6 & 0.25 & 2 & 12 & 36.5 & \\
\hline Damper $\Theta=0^{\circ}, 6 \times 6$ & 8 & & & & & & & 8.0 \\
\hline Diffuser, 6x6 & 8 & & & & & & & 8.0 \\
\hline \multicolumn{9}{|l|}{ Return Side } \\
\hline 12x12 Duct & 8 & 12 & 12 & 1.00 & 2 & 24 & 92.8 & \\
\hline SR5-14 Dovetail WYE & 1 & 12 & 10 & 0.83 & & 22 & & 32.9 \\
\hline ER4-2, Transition, Pyramidal & 2 & 10 & 10 & 0.69 & & 20 & & 38.7 \\
\hline $\begin{array}{l}\text { 10x10 Duct } \\
\text { CR3-14 Elbow (1.5" Vane }\end{array}$ & 2 & 10 & 10 & 0.69 & 15 & 20 & 145.2 & \\
\hline Spc) & 2 & 10 & 10 & 0.69 & & 20 & & 2.0 \\
\hline 10x10 Duct & 2 & 10 & 10 & 0.69 & 2 & 20 & 19.4 & \\
\hline Damper $\Theta=0^{\circ}, 10 \times 10$ & 2 & & & & & & & 2.0 \\
\hline \multirow[t]{2}{*}{ Grille, NC 30 10"x10" } & 2 & & & & & & & 2.0 \\
\hline & & & & & & $\begin{array}{r}\text { Duct } \\
\text { Weight }\end{array}$ & 631.26 & \\
\hline
\end{tabular}

\subsubsection{PTAC and PTHP Equipment Efficiency}

Location in 90.1-2010: $\quad$ Table 6.8.1D

Addendum: $\quad$ 90.1-07bw

Prototype Affected: Small Hotel only

90.1-2007 Table 6.8.1D requires minimum efficiency levels for packaged terminal air conditioners (PTACs) and packaged terminal heat pumps (PTHPs). In 2008, DOE issued a Final Rule, which amends the existing energy efficiency levels for PTACs and PTHPs (DOE 2008). This amended federal energy conservation rule applies for both standard size and nonstandard size PTACs and PTHPs. 90.1-2010 includes more stringent efficiency requirements in Table 6.8.1D which adopts the federal mandatory efficiency standard.

Only the Small Hotel is affected. All PTACs modeled have a capacity of 9,000 Btuh. The 90.1-2007 efficiency is 10.6 EER; the 90.1-2010 efficiency is 11.1 EER. PTACs are commodity items, so PNNL 
searched online for prices of this equipment. Finding units that matched these exact minimum efficiency values and any that were as low as the 90.1-2007 minimum efficiency requirement was difficult as such units are no longer readily available. In many cases there was little consistency in the price differences between different efficiency units. Costs from two different manufacturers were used from the same website (www.applianceconnection.com) resulting in a \$12 higher material cost for the 90.1-2010 case. The 90.1-2007 units had an efficiency of 10.5 EER, and the 90.1-2010 case was based on two units with corresponding EER 11.3 and 11.4.

\subsubsection{Single-Zone VAV}

Location in 90.1-2010: $\quad$ Section 6.4.3.10

Addenda: $\quad$ 90.1-07n and 90.1-07ca

Prototypes Affected: $\quad$ Standalone Retail and Primary School

90.1-2007 does not require HVAC systems serving a single zone to have fan speed control; a constant speed fan is allowed in a HVAC system that serves a single zone.

90.1-2010 Section 6.4.3.10 requires that VAV fan control (either a two-speed motor or a variable speed drive) be used for single zone units above certain size thresholds (single-zone VAV). These systems must comply with the constant volume fan power limitation in 90.1 Section 6.5.3. Depending on the cooling coil type, the size thresholds are as follows:

- for air-handling units with chilled-water cooling coils, if the supply fan motor power is 5 hp or larger, and

- for air-handling units with DX cooling coils, if the DX cooling capacity at ARI rated conditions is $110,000 \mathrm{Btu} / \mathrm{h}$ or greater.

For the cost estimate, achievement of the requirement was assumed to be through the addition of a VFD. With the declining costs of VFDs, use of two-speed motors is becoming less common. Costs for a range of VFD sizes were estimated. The affected systems in the prototypes are all packaged constant volume DX units, so the VFD sizes and costs were assigned based on total cooling capacity, to equipment with capacity above the 110,000 Btu/h threshold. Packaged DX cooling equipment in the size range impacted by this addendum typically include cooling capacity modulation, so no added cost was assumed for that control.

\subsubsection{VAV Dual Minimum Damper Position Control}

Location in 90.1-2010: $\quad$ Section 6.5.2.1 Exception 1.b.

Addendum: $\quad 90.1-07 \mathrm{~h}$

Prototypes Affected: $\quad$ Large Office and Primary School

90.1-2007 requires zone thermostatic controls that prevent simultaneous operation of heating and cooling systems to the same zone. Exceptions are available for VAV systems that reheat cooled air to 
prevent overcooling provided that airflow is minimized before reheat occurs. One exception, 1.A. limits the zone reheat airflow to $30 \%$ of the design peak airflow.

90.1-2010 introduces another alternative, exception 1.b. known as dual minimum damper position control. This exception requires that airflow not exceed 20\% during dead band operation when there is no cooling or heating, and up to $50 \%$ during peak heating demand. Modulation of the damper position between $20 \%$ and $50 \%$ is required during partial cooling and heating. Both of these exceptions include similar provisions that are based on outdoor air requirements, or energy usage, which are not considered relevant to the cost estimate.

Based on input from members of the 90.1 MSC, cost estimator, and the MEP consulting engineers, no added costs were estimated for this control option. The prototype VAV systems were assumed to have direct digital control (DDC) systems with control of the VAV terminal units in each zone in order to comply with other VAV control requirements in Standard 90.1-2007 and Standard 62.1. This control can readily achieve the dual minimum damper control by activating a control sequence that is normally available without addition of any sensors, actuators, or other equipment.

\subsubsection{VAV Supply Air Temperature Reset}

Location in 90.1-2010: $\quad$ Section 6.5.3.4

Addendum: $\quad$ 90.1-07bh

Prototypes Affected: $\quad$ Large Office and Primary School

90.1-2007 does not require multi-zone HVAC systems to include supply air temperature reset. Supply air system temperature would typically be maintained at a constant supply air temperature, commonly around $55^{\circ} \mathrm{F}$.

90.1-2010 requires multi-zone HVAC systems to reset supply air temperature based on changes in building loads or outdoor air temperature. This provision requires that systems be capable of resetting supply air temperature by at least $25 \%$ of the difference between full load supply air temperature and space temperature setpoint when cooling required is less than full load. This is typically a reset of $5^{\circ} \mathrm{F}$ from $55^{\circ} \mathrm{F}$ to $60^{\circ} \mathrm{F}$ based on a full load supply air temperature of $55^{\circ} \mathrm{F}$, and a space temperature of $75^{\circ} \mathrm{F}$. The provision also requires that zones which experience relatively constant loads, such as electronic equipment rooms and some interior zones be designed for the fully reset supply air temperature, potentially requiring an increase in air distribution equipment including ductwork, terminal units, and diffusers. Humid climate subzones 1A, 2A, and 3A are exempt from the requirements because humidity control issues can result from higher supply air temperatures.

There are two methods allowed by 90.1-2010 to control supply air temperature reset. The first method of implementing the control strategy is to reset the temperature in response to outdoor air temperatures based on an outdoor temperature reset schedule. The other method is based on providing cooling at the minimum airflow in the warmest zone at the highest supply air temperature possible. The outdoor reset temperature method is modeled for the 90.1 energy savings analysis (see Energy and Cost Savings Analysis of ASHRAE Standard 90.1-2010). 
The prototype VAV systems were assumed to include DDC systems including control of the VAV terminal units in each zone in order to comply with other VAV control requirements in Standard 90.12007 and Standard 62.1. This type of control can readily achieve the supply air temperature outdoor air reset control by activating a control sequence that is normally available without addition of any sensors, actuators, or other equipment.

The additional requirement applies to the VAV systems in the selected climate subzones 3B, 4A and $5 \mathrm{~A}$ for the large office buildings and the primary school. The MEP consulting engineers and the cost estimator concluded that this strategy could be implemented without adding equipment or installation costs. The MEP consulting engineers provided an added cost for commissioning based on 4 man-hours of programming and 4 man-hours of commissioning for each affected VAV system.

As discussed above, zones which experience relatively constant loads may need to be designed for increased airflow in order to meet load at the fully reset supply air temperature. When analyzing the costeffectiveness of this particular addendum, the 90.1 MSC used an estimate of \$0.19 per square foot of interior building area served by HVAC systems affected by the control requirement to account for increased air distribution equipment. This cost was added to a portion of the interior zones of the large office with relatively constant loads.

For the primary school, all of the spaces served by the VAV systems are exposed to exterior solar and outdoor air temperature loads through the roof and in most cases through the exterior walls and windows so the loads are not constant. It was assumed that ductwork is already designed for larger loads at peak conditions and is capable of handling interior loads from lighting, equipment and occupants in lower external load conditions when the supply air temperature is being reset.

\subsubsection{VAV System Ventilation Optimization Control}

Location in 90.1-2010: $\quad$ Section 6.5.3.3

Addendum: $\quad 90.1-07 \mathrm{ck}$

Prototypes Affected: $\quad$ Large Office and Primary School

90.1-2007 does not include requirements for reset of outside air volume to account for changing ventilation efficiency as VAV system airflow changes. 90.1 -2007 just references Standard 62.1-2004 as the reference standard for ventilation which governs multi-zone ventilation, and results in a fixed volume of outside air being provided whenever the system is operating (outdoor airflow will vary if demand controlled ventilation is required). Furthermore, the volume of air is generally greater than the sum of the minimum prescriptive outdoor air required at each zone under the multi-zone provisions in Standard 62.1.

90.1-2010 includes a new Section, Section 6.5.3.3, Multiple-zone VAV System Ventilation Optimization Control. This includes a requirement that multiple-zone VAV systems automatically reduce outdoor air intake flow in response to changes in system ventilation efficiency, as defined by Standard 62.1-2007. The requirement applies to systems with DDC control of individual terminal units. Essentially, this control requires continuously calculating outside air requirements based on zonal damper positions using the multi-zone system method in Standard 62.1 Appendix A. A detailed description of this control 
strategy and the multi-zone calculations is included in Energy and Cost Savings Analysis of ASHRAE Standard 90.1-2010.

VAV systems typically require DDC control of zone dampers and outdoor airflow sensors in the AHU or roof top unit (RTU) in order to meet other provisions of Standard 90.1.2007 and requirements under Standard 62.1. Added costs for ventilation optimization control were limited to programming and checkout/commissioning. Costs include 30 minutes programming for each perimeter zone, and 1 hour (2 people, 30 minutes each) for commissioning per perimeter zone. Costs were applied based on the number of perimeter zones for each affected prototype system. The specific values used were from the MEP consulting engineers with similar information provided by the cost estimator and the 90.1 MSC.

\subsubsection{Automatic Outdoor Air Dampers}

Location in 90.1-2010: $\quad$ Section 6.4.3.4.2

Addendum:

Prototypes Affected:
$90.1-07 c b$

Small Office, Standalone Retail and Primary School

90.1-2007 Sections 6.4.3.4.2 and 6.3.4.3.3 allow non-motorized rather than motorized dampers with automatic shut-off control for outdoor air intakes, ventilation inlets, and exhaust and relief systems for buildings under three stories in height above grade, and any height in climate zones 1, 2 and 3, and for systems with outdoor airflow under 300 CFM. Section 6.4.3.4.4 excludes non-motorized dampers in climate zones 1, 2, 6, 7 and 8. Systems that qualify for the simplified approach to compliance under 90.12007 Section 6.3 are not subject to the damper control requirements at all.

90.1-2010 combines the damper requirements into one Section 6.4.3.2, removes the building height and climate exceptions for outdoor air intakes separate from other damper applications, and adds compliance with the damper control requirements to Section 6.3. There are other elements to these requirements, but these preceding sentences covers those relevant to the cost estimate.

As a result of these changes, some outdoor air dampers in the 90.1-2007 prototype models that were non-motorized are required to be motorized in the 90.1-2010 models. For the cost estimate, the Standalone Retail, Primary School, Small Office and Mid-rise Apartment (common area HVAC systems) which are less than three stories change to motorized outdoor air intake dampers.

Cost estimates for non-motorized and motorized dampers for a range of outdoor airflows were provided by the cost estimator and applied to the prototypes in sizes according to the modeled outdoor airflows. Incremental annual maintenance costs for motorized compared to non-motorized dampers were estimated by PNNL from several sources including prior experience, RS Means Facilities, Maintenance and Repair Guidebook for selected labor hours (RS Means 2004) and an online product catalog (Nextag 2012). Maintenance costs include an annual check including verifying that motors are rotating smoothly and set screws are adjusted properly. Actuators need to be replaced approximately every three to five years. 


\subsubsection{Economizer}

Location in 90.1-2010: $\quad$ Section 6.5.1

Addendum: $\quad$ 90.1-07cy

Prototypes Affected: $\quad$ Large Office, Standalone Retail, Primary School, and Small Hotel

Standard 90.1-2007 requires most HVAC systems in most climate zones to include air-side or waterside economizers. 90.1-2010 includes many changes from 90.1-2007 that increase the prevalence of the economizer requirements. The primary changes that result in significant energy savings and increased equipment costs include increasing the number of climate subzones in which systems are required to have economizers and lowering the cooling capacity size limit above which an economizer is required..

- Economizer requirements were added for climate subzones 2A, 3A, and 4A, which were formerly exempt. Climate zones $1 \mathrm{~A}$ and $1 \mathrm{~B}$ remain exempt.

- The cooling capacity above which an economizer is required is reduced to $54,000 \mathrm{Btu} / \mathrm{h}$ for all climate subzones except $1 \mathrm{~A}$ and $1 \mathrm{~B}$. This change reduces the threshold down from 135,000 Btu/h for climate zones 2B, 5A, 6A, 7 and 8 and down from 65,000 Btu/h for climate zones 3B, 3C, 4B, $4 \mathrm{C}, 5 \mathrm{~B}, 5 \mathrm{C}$, and $6 \mathrm{~B}$.

Eliminating the exceptions for nonintegrated economizers also affected energy savings. However the change only requires modification to the equipment set-up and installation, and the professional cost estimator determined that this change does not add equipment costs.

Economizers were added to HVAC systems in the selected prototypes as follows:

- Small Office and Mid-rise Apartments - none, all systems are smaller than the old and new cooling capacity thresholds

- $\quad$ Large Office and Primary School - added to climate subzones 2A, 3A, and 4A.

- Standalone Retail and Small Hotel - added to climate subzones 2A, 3A, and 4A, and for selected systems in 3B and 5A with cooling capacity that falls above the new size threshold

Economizer cost estimates for a range of outdoor airflows were provided by the cost estimator and applied to the prototypes as modeled according to the requirements in the respective editions of Standard 90.1 .

Annual maintenance costs for the HVAC systems with added economizers were estimated by PNNL from several sources including staff experience, RS Means Facilities, Maintenance and Repair Guidebook for selected labor hours (RS Means 2004) and an online product source (Nextag 2012). Maintenance includes verification that the economizer opens, closes, and appears to function properly and replacement of actuators every three to five years.

\subsubsection{Exhaust Air Energy Recovery}

Location in 90.1-2010: $\quad$ Section 6.5.6 
Addenda:

90.1-07e and 90.1-07dj

Prototypes Affected: $\quad$ Large Office, Standalone Retail, and Primary School

90.1-2007 requires that exhaust air energy recovery ventilators (ERVs) be used if a fan system supply air capacity is 5,000 CFM or larger, and the design minimum outdoor air supply is $70 \%$ or more of the design supply air.

90.1-2010 greatly expands the application of energy recovery by establishing a range of values for systems, in some cases lowering the thresholds for design supply air capacity with lower ratios of outdoor air varying by climate subzone, as shown in Table 4.4 in this report.

Table 4.4. Energy Recovery Requirements by Climate Zone and Outdoor Air Fraction

\begin{tabular}{lcccccc}
\hline & \multicolumn{5}{c}{ Outdoor Air Fraction at Design Air Flow Rate } \\
\cline { 2 - 7 } \multicolumn{1}{c}{ Climate zone } & $30-40 \%$ & $40-50 \%$ & $50-60 \%$ & $60-70 \%$ & $70-80 \%$ & $\geq 80 \%$ \\
\cline { 2 - 7 } & $\mathrm{NR}^{1}$ & $\mathrm{NR}$ & $\mathrm{NR}$ & $\mathrm{NR}$ & $\geq 5,000$ & $\geq 5,000$ \\
\hline 3B, 3C, 4B, 4C, 5B & $\mathrm{NR}$ & $\mathrm{NR}$ & $\geq 26,000$ & $\geq 12,000$ & $\geq 5,000$ & $\geq 4,000$ \\
1B, 2B, 5C & $\geq 11,000$ & $\geq 5,500$ & $\geq 4,500$ & $\geq 3,500$ & $\geq 2,500$ & $\geq 1,500$ \\
6B & $\geq 5,500$ & $\geq 4,500$ & $\geq 3,500$ & $\geq 2,000$ & $\geq 1,000$ & $\geq 0$ \\
1A, 2A, 3A, 4A, 5A, 6A & $\geq 2,500$ & $\geq 1,000$ & $\geq 0$ & $\geq 0$ & $\geq 0$ & $\geq 0$ \\
7, 8 &
\end{tabular}

${ }^{1} \mathrm{NR}$ not required

Energy recovery ventilators were added to HVAC systems in the selected prototypes as follows:

- Small Office, Small Hotel, and Mid-rise Apartment - none, no systems meet the thresholds established in Table 4.4

- $\quad$ Large Office, Standalone Retail and Primary School - added to selected systems in climate subzones $2 \mathrm{~A}, 3 \mathrm{~A}$, and $4 \mathrm{~A}$ and $5 \mathrm{~A}$

The cost estimate was based on energy recovery wheel type systems with similar equipment added to AHU or RTU equipment. The added cost was estimated as \$3.75 per CFM of outside air (Witte and Henninger 2006).

Maintenance for an ERV is similar to that for a packaged DX unit and includes lubrication, checking dampers, adjusting belts, replacing filters, checking door seals and cleaning coils. PNNL estimated annual maintenance costs from two sources. RS Means Mechanical Cost Data 2012 provided a rough estimate for a set of routine packaged DX maintenance activities that total about 2.5 man-hours. Cleaning of the energy recovery media is also included with maintenance, and can take about 15 minutes with frequency from every six months to 10 years depending on conditions, so the estimate included 15 minutes each year (AirXchange 2012). 


\subsubsection{Kitchen Exhaust Hoods}

Location in 90.1-2010: $\quad$ Section 6.5.7

Addendum: $\quad 90.1-07 \mathrm{ax}$

Prototype Affected: $\quad$ Primary School

90.1-2007 has make-up air requirements for individual kitchen exhaust hoods with exhaust airflow greater than 5,000 CFM. The 90.1-2007 Primary School kitchen exhaust is modeled as 5,000 CFM based on input from ASHRAE Technical Committee TC5.10 members (Kitchen Ventilation) and is not affected by the requirements.

90.1-2010 includes multiple provisions that affect the design and exhaust volume and the costs of kitchen exhaust systems hoods.

- The exhaust maximum airflow values in 90.1-2010 Table 6.5.7.1.3 are 30\% below the values allowed in ASHRAE Standard 154-2003. For the energy savings analysis, it was assumed that many kitchen exhaust systems already meet these lower exhaust airflow requirements, and the modeled 90.1-2010 exhaust airflow was set 10\% below the value included for the 90.1-2007 case. The 90.1-2010 kitchen exhaust air volume was set as 4,500 CFM.

- Transfer air from surrounding spaces on the same floor as the kitchens are required to be used as the first source of exhaust makeup air. No costs are identified for this, and the assumption is that this air can be transferred through doorways and other openings between spaces. Differences in the makeup air volume for the case with the use of transfer air compared to $100 \%$ make-up air were accounted for under the general HVAC capacity costs (see Section 4.2.1.1 in this report).

The difference in costs specifically identified for this provision was for the two different sized exhaust fans. Equipment cost was obtained from an online restaurant equipment catalog (Restaurant Max Inc. 2013), and labor costs from RS Means Mechanical Cost Data 2012 for a similar exhaust fan.

\subsubsection{Chilled Water and Condenser Water Pipe Sizing}

Location in 90.1-2010: $\quad$ Section 6.5.4.5

Addenda: $\quad$ 90.1-07af and 90.1-07cc

Prototype Affected: $\quad$ Large Office

90.1-2007 does not include requirements for chilled and condenser water pipe sizing and pipe sizing in the cost estimate was based on standard design practice as recommended by the SSPC 90.1 Mechanical Subcommittee. Section 6.5.4.5 of 90.1-2010 adds Table 6.5.4.5 which sets minimum pipe sizes for a given flow resulting in large piping being required in the 2010 office prototype. Energy and Cost Savings Analysis of ASHRAE Standard 90.1-2010 includes a table which compares these flow requirements. 
Piping costs were estimated as part of the HVAC capacity change costs described in Section 4.2.1.1 in this report, and these costs included the differences in pipe sizing under 90.1-2010 compared to previous design practice.

\subsubsection{Hydronic Variable Flow Control}

Location in 90.1-2010: $\quad$ Section 6.5.4.1

Addendum: $\quad$ 90.1-07ak

Prototype Affected: $\quad$ Large Office

The cost increases from changes from 90.1-2007 to 90.1-2010 in Section 6.5.4.1 for hydronic system pumping were due primarily to two changes. The threshold for variable flow control for individual chilled water pumps was lowered from 50 motor horsepower (hp) to $5 \mathrm{hp}$. Variable flow pumping is required to be controlled through differential pressure setpoint reset.

The Large Office is the only prototype affected by the hydronic flow control requirement. The Large Office includes chilled water pumps with motor sizes between $5 \mathrm{hp}$ and $50 \mathrm{hp}$ that have added costs for VFDs, and differential pressure setpoint control in the 2010 prototypes.

Costs for VFDs for a range of sizes were estimated with the HVAC equipment capacity change costs described in Section 4.2.1.1 in this report, and were assigned to the appropriate pump costs for the Large Office. The Large Office prototype was assumed to include a DDC system for both editions of Standard 90.1, typical for buildings of this size, which includes control of pumping. Adding pump differential pressure setpoint reset control is estimated by the MEP consulting engineers to not include any additional equipment, only two man-hours of programming and implementation and two man-hours of commissioning.

\subsubsection{Open-Circuit Cooling Tower Performance}

Location in 90.1-2010: $\quad$ Section 6.4.1.1 and Table 6.8.1G

Addendum: $\quad 90.1-07 \mathrm{u}$

Prototype Affected: $\quad$ Large Office

90.1-2007 Section 6.5.5 requires cooling towers to meet the following performance criteria at standard rating conditions $\left(95^{\circ} \mathrm{F}\right.$ entering water, $85^{\circ} \mathrm{F}$ leaving water, and $75^{\circ} \mathrm{F}$ wb outdoor air).

- For propeller or axial fan cooling towers, the maximum flow rating of the tower divided by the fan nameplate rated motor power must be at least $38.2 \mathrm{gpm} / \mathrm{hp}$.

- For centrifugal fan cooling towers, the maximum flow rating of the tower divided by the fan nameplate rated motor power must be at least $20.0 \mathrm{gpm} / \mathrm{hp}$. 
90.1-2010 requires that centrifugal fan open-circuit cooling towers with rated capacity of 1,100 gpm or greater meet the more stringent performance requirement of axial fan open-circuit cooling towers (at least $38.2 \mathrm{gpm} / \mathrm{hp})$.

The Large Office prototype cooling towers meet the corresponding cooling tower efficiency requirements. However, based on information from the 90.1 MSC, the cost estimator, and cooling tower manufacturers, no cost was added for more efficient cooling towers for the 90.1-2010 case. Axial fan cooling towers require about half the fan power for a given cooling capacity, and cost about the same or less than an equivalent capacity centrifugal fan cooling tower. Due to lower fan power with no increase in cost, axial fan cooling towers will generally be applied to meet the 90.1-2010 requirements, rather than trying to find centrifugal fan cooling towers that can meet the higher efficiency requirement. Centrifugal cooling towers will continue to be used when needed for noise control and space limitations as allowed by exceptions in the 90.1-2010 requirements.

\subsubsection{Chiller Efficiency Improvements}

Location in 90.1-2010: $\quad$ Section 6.4.1.1 and Table 6.8.1C

Addendum: $\quad 90.1-07 m$

Prototype Affected: $\quad$ Large Office

The minimum efficiency requirements for air-cooled and water-cooled chillers are specified in 90.12007 Section 6.4.1.1 under Table 6.8.1C. Standard 90.1-2010 increases the efficiency required, and expands the options for meeting the minimum efficiency requirements into two paths for water-cooled chillers, path A which raises the minimum full and part load efficiency, and path B which raises minimum part load efficiency even further, and raises or in some cases reduces somewhat full load efficiency. The 90.1-2010 Large Office prototype chillers meet the requirements under path B. Path B chillers achieve their part load efficiency improvement by incorporating a variable frequency drive (VFD).

The cost estimator developed costs for the 90.1-2007 efficiency equipment under the HVAC general load capacity costs in Section 4.2.1.1 in this report. Incremental equipment cost for chillers that meet 90.1-2010 path B efficiency were found by subtracting the 90.1-2007 efficiency chiller cost from the higher 90.1-2010 efficiency chiller costs at the range of chiller capacities that cost estimates were provided for. Labor costs were assumed to be the same for same sized chillers of different efficiency. Table 4.5 in this report shows the minimum efficiency requirements for water-cooled centrifugal chillers. 
Table 4.5. 90.1-2007 and 90.1-2010 Chiller Efficiencies

\begin{tabular}{|c|c|c|c|c|}
\hline $\begin{array}{l}\text { Equipment } \\
\text { Type }\end{array}$ & Size Category & $\begin{array}{c}\text { 90.1-2007 Minimum } \\
\text { Efficiency }\end{array}$ & $\begin{array}{l}\text { 90.1-2010 Path A } \\
\text { Minimum Efficiency }\end{array}$ & $\begin{array}{l}\text { 90.1-2010 Path B } \\
\text { Minimum Efficiency }\end{array}$ \\
\hline \multirow[t]{4}{*}{$\begin{array}{l}\text { Water Cooled, } \\
\text { Centrifugal }\end{array}$} & $<150$ tons & $\begin{array}{l}0.703 \mathrm{~kW} / \mathrm{ton} \text { and } \\
0.669 \mathrm{IPLV}^{1}\end{array}$ & $\begin{array}{l}0.634 \mathrm{~kW} / \mathrm{ton} \text { and } \\
0.596 \mathrm{IPLV}\end{array}$ & $\begin{array}{l}0.639 \mathrm{~kW} / \mathrm{ton} \text { and } 0.450 \\
\text { IPLV }\end{array}$ \\
\hline & $\begin{array}{l}\geq 150 \text { tons and } \\
<300 \text { tons }\end{array}$ & $\begin{array}{l}0.634 \mathrm{~kW} / \mathrm{ton} \text { and } \\
0.596 \mathrm{IPLV}\end{array}$ & & \\
\hline & $\begin{array}{l}\geq 300 \text { tons and } \\
<600 \text { tons }\end{array}$ & $\begin{array}{l}0.576 \mathrm{~kW} / \mathrm{ton} \text { and } \\
0.549 \mathrm{IPLV}\end{array}$ & $\begin{array}{l}0.576 \mathrm{~kW} / \mathrm{ton} \text { and } \\
0.549 \mathrm{IPLV}\end{array}$ & $\begin{array}{l}0.600 \mathrm{~kW} / \mathrm{ton} \text { and } 0.400 \\
\text { IPLV }\end{array}$ \\
\hline & $\geq 600$ tons & & $\begin{array}{l}0.570 \mathrm{~kW} / \text { ton and } \\
0.539 \mathrm{IPLV}\end{array}$ & $\begin{array}{l}0.590 \mathrm{~kW} / \text { ton and } 0.400 \\
\text { IPLV }\end{array}$ \\
\hline
\end{tabular}

${ }^{1}$ IPLV - integrated part load value

\subsubsection{Lighting}

90.1-2010 incorporates major changes that reduce lighting energy usage. Basic lighting power density (LPD) requirements were changed for both interior and exterior lighting. For the first time, addenda introduce rules that require access to daylight and daylighting controls. Significant controls requirements were added or changed for both interior and exterior lighting.

\subsubsection{Addendum 90.1-07by and 90.1-07de: Interior LPD Allowance}

Location in 90.1-2010: $\quad$ Section 9.2.2.3 and Table 9.6.1

Addenda: $\quad$ 90.1-07by and 90.1-07de

Prototypes Affected: $\quad$ All six

90.1-2007, Chapter 9, includes requirements for maximum LPD in watts per square foot $\left(\mathrm{W} / \mathrm{ft}^{2}\right)$. Two prescriptive methods are allowed and tables of maximum LPD values are provided. The primary compliance path uses Table 9.5.1 which includes LPDs that are applied to an entire building area. An alternative path uses Table 9.6.1, which allows assignment of maximum LPDs to specific space types. 90.1-2010 includes a full update of both sets of LPD values. The maximum allowed LPD values decrease generally with some exceptions.

Tables 9.5.1 and 9.6.1 in 90.1-2007, and 90.1-2010 are not included in this report and can be viewed in those different editions of Standard 90.1.

Part of the basis for the interior lighting power cost development was a set of lighting building space models that were used by the 90.1 LSC to develop the maximum allowed LPD values.

The models incorporate interior lighting design elements including:

- Illuminating Engineering Society (IES) recommended light levels in footcandles (FC),

- $\quad$ Light source efficacy, lumens/watt $(\mathrm{lm} / \mathrm{W})$,

- Lamp, fixture, and room surface light loss factors, 
- Fixture coefficient of utilization (CU) related to expected room geometry.

In developing the LPD limits, 90.1 LSC design experts determined an appropriate application mix of fixture types and lighting sources and what portion of the recommended light level(s) is provided by each combination. The mix of lighting technology for each space type was defined for both 90.1-2007, and 90.1-2010. Finally, the combined lamp efficacy, loss factors, and CU values for the various fixtures and sources were used to calculate the wattage needed to provide the recommended level of lighting.

Each space type or building area type was assigned up to four lighting systems each of which provided an assigned percentage of the overall total illumination for that space. These percentages determined the quantity per square foot of each fixture and luminaire type and the respective lighting power in watts.

Material and labor costs were estimated for each fixture type and lamp type. These costs were applied to the lighting design information to calculate a cost $/ \mathrm{ft}^{2}$ for each space type or building area type. In cases where the LSC incorporated a significant shift in lighting design philosophy from 2007 to 2010 resulting in a change to lighting technology unrelated to a change in LPD, one of the designs was selected, and adjustments were made in the quantity of fixtures installed while maintaining similar fixture types. For example, enclosed offices had higher-priced direct/indirect fixtures in the 2007 design compared to direct linear fixtures in the 2010 design. To maintain cost equity, the 2010 design was used for both, with an adjustment in total fixtures included to match the LPD change.

Fixture (including ballast and lamp) costs were determined using Grainger's online catalog (Grainger 2012). Other online catalogs were used for fixture/lamp costs when Grainger did not carry the product (Amazon 2012; BuyLightFixtures 2012; Goodmart 2012). RS Means Electrical Cost Data 2012 was used for labor costs and for a few lighting equipment items not available in the other sources (RS Means 2012B). Besides cost, lamp life and complete connected luminaire wattage per fixture were recorded. Fixture cost per Watt $(\$ / W)$ was calculated by dividing the total cost by the fixture wattage.

The formula used to calculate the cost per fixture types is:

Cost per $\mathrm{ft}^{2}$ per fixture type $=($ total illumination, lumens $\times$ percentage of lumens provided by fixture type $\times$ fixture $\$ / W$ ) / efficacy of the lighting system in $\mathrm{lm} / \mathrm{W}$.

The total cost per space type, $\$ / \mathrm{ft}^{2}$ was determined by combining the costs per fixture per $\mathrm{ft}^{2}$ in proportion to the percentage of total illumination provided by each fixture described above. The cost per space type, $\$ / \mathrm{ft}^{2}$ was multiplied by the area of each space type represented in each prototype to determine the total interior lighting power cost for each prototype.

Replacement life for each lamp and ballast was determined by dividing the lamp or ballast life by the annual full load equivalent hours from the corresponding energy model schedule for the assigned space type (modeling schedules were described in Energy and Cost Savings Analysis of ASHRAE Standard 90.1-2010). Replacement costs were separated into the different replacement lives, for example, a space type may have included lamp replacement costs every three years and every five years for two different types of lamps. 


\subsubsection{Occupancy Sensor Control of Interior Lighting}

Location in 90.1-2010: $\quad$ Sections 9.4.1.2 Exception b. and 9.4.1.6 c. and g, and 9.4.4.

Addenda: $\quad$ 90.1-07x, aa, cf, and aw

Prototypes Affected: $\quad$ At least one space type in all six prototypes

Both 90.1-2007 and 90.1-2010 include requirements for automatic controls that turn off lights when spaces are unoccupied for a period of time after occupants leave the space. 90.1-2010 adds space types required to meet the requirements, and when occupancy sensors are used, these must be a newer type of sensor, manual on/auto off, which only turns off automatically and must be switched on, for some space types, rather than conventional automatic on/off control. For the cost estimate, the automatic controls were assumed to be occupancy sensors, the most common method used. 90.1-2010 Section 9.4.4 introduces functional testing requirements (part of the commissioning effort for lighting controls.

In 90.1-2010 automatic control requirements were added for:

- Lecture halls and non-shop or laboratory classrooms, and all other classrooms in preschool through 12th grade were added to classrooms

- Training rooms were added to conference and meeting rooms

- Storage and supply rooms between $50 \mathrm{ft}^{2}$ and $1,000 \mathrm{ft}^{2}$, copy and printing rooms, offices up to $250 \mathrm{ft}^{2}$, restrooms, and dressing, locker, and fitting rooms

- Interior stairwells

- Hotel guest room bathrooms

Manual on/auto off occupancy sensors are required when occupancy sensors are applied except in public corridors and stairwells, restrooms, primary building entrances, and areas where manual on control would endanger safety or security.

The cost estimate began by determining how many and what type of sensors are required in the affected space types. Because spaces in the models vary in size and there are many spaces, developing a specific design for each modeled space was not practical. Instead, representative spaces and occupancy control types (such as for small bathrooms) were developed. These spaces were based on the range of space sizes and space types in the models, and the typical space dimensions in the NC3 database developed by PNNL to characterize commercial construction (Thornton et al. 2011, Richman et al. 2008). For each representative space, types of sensor were determined. Each type of sensor was estimated to serve up to a defined area. were The quantity of sensors applied to the space types in the model was found by dividing the area of the space types by the area served per sensor. Table 4.6 shows the types of occupancy sensors considered.

Cost estimates for each type of occupancy sensor including equipment costs were found in the Grainger catalog online, and labor costs in the RS Means Electrical Cost Data (Grainger 2012, RS Means 2012B). 
Table 4.6. Occupancy Sensor Control Types

\begin{tabular}{ll}
\hline \multicolumn{1}{c}{ Control Type } & \multicolumn{1}{c}{ Sensor Equipment Type } \\
\hline Auto on/off & Wall mount infrared \\
Auto on/off & Wall mount ultrasonic \\
Auto on/off & Wall mount infrared and ultrasonic \\
Auto on/off & Ceiling mount infrared \\
Auto on/off & Ceiling mount ultrasonic \\
Auto on/off & Ceiling mount infrared and ultrasonic \\
\hline Auto on/off & Ceiling mount infrared and ultrasonic \\
Manual on/off & Wall mount infrared \\
Manual on/off & Wall mount infrared \\
Manual on/off & Wall mount ultrasonic \\
Manual on/off & Wall mount infrared and ultrasonic \\
Manual on/off & Ceiling mount infrared \\
Manual on/off & Ceiling mount infrared \\
\hline
\end{tabular}

These costs were applied to the prototypes according to the space type areas in the prototypes. For each space type, the area was divided by the appropriate representative controlled space from the occupancy sensor details. This resulted in the number of controlled spaces. Costs per controlled space types were multiplied by the number of controlled spaces. Costs were applied to both 90.1-2007 and 90.12010 prototypes for space types required to include automatic controls.

90.1-2010 requires functional testing to verify that occupancy sensors operate effectively and within the time limits required by 90.1-2010. Commissioning costs focused on 90.1-2010 required functional testing were estimated based on review of three documents. Energy Efficiency Factsheet (WSU 2005) estimates that building commissioning is between two to four percent of the construction cost of the system. Fimek states that lighting control start-up and commissioning is 6-7\% but it does not specify what the percentage is applied to (Fimek 2011). This is assumed to be 7\% of the cost of lighting controls including labor. Peterson provides a variety of estimates (Peterson and Haasl1994):

- $\quad$ Northeast utility uses $\$ 0.20-0.67 / \mathrm{ft}^{2}$

- Northwest utility uses $6 \%$ of total measure cost

- Commissioning agents use $1-4 \%$ of total measure cost or $\$ 0.01-0.10 / \mathrm{ft}^{2}$

Based on these documents, the range of commissioning costs for lighting controls is $1 \%$ to $7 \%$ of the total lighting controls costs including labor with an average of $4 \%$. Applying the $4 \%$ value to the lighting controls costs for the prototypes results in an added cost of $\$ 0.01 / \mathrm{ft}^{2}$. This falls within the range of potential costs identified for commissioning in the review and $4 \%$ of the total control costs were used for incremental commissioning cost of the controls.

\subsubsection{Daylighting Controls}

Location in 90.1-2010: $\quad$ Sections 9.4.1.4, 9.4.1.5 and 9.4.4

Addenda: $\quad$ 90.1-2007 d, ab, al, dd and ct

Prototypes Affected: $\quad$ All selected prototypes except Mid-rise Apartment 
90.1-2007 Chapter 9 Lighting does not require automatic dimming control of light fixtures in daylit areas. 90.1-2010 Sections 9.4.1.3 and 9.4.1.4 requires automatic dimming controls in response to daylight for toplit and sidelit areas. 90.1-2010 Section 9.4.4 introduces functional testing requirements (part of commissioning) for lighting controls. Related to the daylighting controls, 90.1-2010 adds requirements in Chapter 5 Building Envelope for minimum skylight fenestration area and minimum daylit area; additional skylight costs are included in Section 4.2.3 in this report with the other building envelope cost items.

Toplighting Controls: Addendum 90.1-07ab adds 9.4.1.5 which requires lamps for general lighting over the daylit area to be separately controlled by multi-level photocontrol devices when the total daylit area under skylights exceeds $900 \mathrm{ft}^{2}$.

Sidelighting Controls: Addendum 90.1-07ct adds 9.4.1.4 and requires lamps for general lighting to be separately controlled by automatic daylighting controls when the primary sidelit area in a space is 250 $\mathrm{ft}^{2}$ or larger.

For both types of daylit areas, the minimum control is two step controls, one between $50 \%$ and $70 \%$, and one at no greater than $35 \%$ of lighting design power and operation at full power.

Toplighting and sidelighting are applied as shown in Table 4.7.

Table 4.7. Application of Daylighting Controls by Prototype and Space

\begin{tabular}{|c|c|c|c|c|}
\hline $\begin{array}{l}\text { Prototype/Type of } \\
\text { Control }\end{array}$ & Spaces affected & $\begin{array}{l}\text { Daylit area } \\
\left(\mathrm{ft}^{2}\right)\end{array}$ & $\begin{array}{l}\text { Quantity of } \\
\text { fixtures }\end{array}$ & $\begin{array}{l}\text { Quantity of sensors and } \\
\text { controlled light banks }\end{array}$ \\
\hline \multicolumn{5}{|c|}{ Toplighting Controls } \\
\hline Standalone Retail & Core Retail & 8,614 & 238 & 1 \\
\hline Primary School & Multipurpose Room & 3,843 & 44 & 1 \\
\hline \multicolumn{5}{|c|}{ Sidelighting Controls } \\
\hline Small Office & $\begin{array}{l}\text { Perimeter open and enclosed offices } \\
\text { and conference rooms }\end{array}$ & 1,220 & 28 & 4 \\
\hline Large Office & $\begin{array}{l}\text { Perimeter open and enclosed offices } \\
\text { and conference rooms }\end{array}$ & 65,220 & 1,500 & 150 \\
\hline Primary School & $\begin{array}{l}\text { Multiple classrooms, lobby, offices } \\
\text { gym, cafeteria and library }\end{array}$ & 15,411 & 171 & 40 \\
\hline Small Hotel & Front Lounge & 423 & 4 & 1 \\
\hline
\end{tabular}

Costs for material, labor and commissioning were developed by PNNL from cost data produced by a daylighting consultant. The daylighting consultant provided cost data to PNNL in support of PNNL's work to evaluate further changes to daylighting for 90.1-2013. The costs used for this cost estimate were for a two-step switchable wired photo-sensor control system. Other options are wireless systems, and dimmable rather than step control. Dimmable systems are not required in order to meet the minimum step control required in 90.1-2010, although dimming is often applied to improve the visual comfort of occupants.

In the Small Office and Large Office one photo sensor was assumed per perimeter zone to represent the open office areas and one photosensor was provided in each perimeter private office space and 
conference room. For the other prototypes, each affected space was assumed to have one photosensor and one bank of lights.

One power pack is required per controlled bank of lights. The number of banks of lights was assumed to be one per daylit zone. The two toplit areas in the Standalone Retail and the Primary School prototypes are open spaces which are each one daylit zone.

Costs are also incurred for connecting control wiring to each fixture. Five minutes installation per fixture was estimated. The number of fixtures in the daylit areas was determined. The starting point for these calculations was the fixtures per $\mathrm{ft}^{2}$ values developed for the 90.1 analysis as described in Section 5.2.2.1 in this report. The sidelit and toplit daylit areas were multiplied by the quantity of fixtures per $\mathrm{ft}^{2}$ as determined for the interior lighting power allowance cost calculations.

Replacement and commissioning costs focused on the 90.1-2010. Required functional testing costs were estimated based on information provided by the daylighting consultant.

- Replacement costs involve only the cost of photosensor and power pack; the lighting was assumed to stay in place;

- For new construction ten minutes of commissioning were estimated for each fixture. The control wiring was not replaced during the study period of the 90.1 cost-effectiveness study.

- Functional testing, including calibration of photo sensors was assumed to be a small cost that is included with two hours of installation per photo sensor.

\subsubsection{Exterior Lighting Power and Controls}

Location in 90.1-2010: $\quad$ Sections 9.4.3 and 9.4.1.7

Addenda: $\quad$ 90.1-07i and 90.1-07cd

Prototypes Affected: $\quad$ All six selected prototypes

90.1-2007 Section 9.4.3 and Table 9.4.5 require exterior lighting power to fall below a maximum power allowance which is the sum of various allowances by space area, length or quantity plus $5 \%$ additional power. 90.1-2007 Section 9.4.1.3 requires controls to turn lights off when sufficient daylight is present or when the lighting is not required during nighttime hours.

90.1-2010 provides similar exterior lighting requirements in Section 9.4.3 and renumbered Table 9.4.3B. However, the allowances are defined for five exterior lighting zones related to the level of development of the surrounding areas of the building. The power allowance values vary in some cases between the zone types. 90.1-2010 requires the same type of lighting controls as 90.1-2007 but also adds additional lighting control requirements. Exterior facade and landscape lighting are shall be automatically turned off between business closing or midnight, whichever is later, until 6:00 am or business opening, whichever is earlier. Exterior lighting not specified as façade or landscape lighting, including advertising signage, is to be automatically reduced to $30 \%$ of its peak power between midnight or within 1 hour of 
business closing, whichever is later, and until 6:00 am or business opening, whichever is earlier, or during any period activity is not detected for a time longer than 15 minutes.

The exterior lighting power allowances were calculated for each prototype for 90.1-2007 and 90.12010. For 90.1-2010, each prototype was identified with one or two of the new exterior lighting zones. Those with two lighting zones were weighted 50\% for each zone type. Most of the exterior lighting power for the prototype buildings is used for parking, entrances, and façades. The area and quantities of these was defined to calculate the lighting power allowances.

Comprehensive lighting models used to develop the exterior lighting power allowances were not available for 90.1-2010 in a form compatible with defining the specific prototype exterior lighting for the cost estimate. Instead, a PNNL lighting expert utilized the lighting power allowance and the parking area, quantity of entrances and façade areas to develop sufficient equipment and installation detail for the cost estimate. The quantity of equipment was adjusted assuming standard lighting equipment provided to just meet the maximum power allowance values from the two editions of Standard 90.1.

Costs for fixtures, lamps, ballasts and occupancy sensors were developed by PNNL from the current Grainger catalog and other online sources. Costs for parking lighting poles and electrical conduit in poured concrete were extracted from the RS Means Electrical Cost Data (RS Means 2012B).

Replacement costs were estimated for lamps and ballasts and replacement lives were calculated from useful life of the products divided by the exterior lighting hours of operation extracted from the prototype model output reports. Costs for individual components were determined and total costs per prototype were calculated by multiplying the quantity of the components. Fractional quantities were used because the prototypes were considered representative of a class of buildings, and because the energy savings were based on the exact lighting power allowance, not a whole quantity of lighting equipment.

\section{Parking}

For each prototype, an LPD is provided by Standard 90.1 (both editions) for parking lots in W/ft ${ }^{2}$. The allowed LPD value was multiplied by the area of the site parking to determine the total allowed power for that application at the site. A typical fixture type was selected for the parking lot, with an appropriate type of lamp and ballast. The input power to the ballast was used to calculate the number of fixtures that could be installed within the allowed power values.

The average initial illuminance of the lighting system was calculated by taking the initial lumens of the lamp, multiplying by the fixture efficiency (the amount of light that actually leaves the fixture compared to that generated by the lamp) divided by the area of the parking. This was done to verify the reasonableness of the schematic design, although this is constrained to meet the maximum power allowance.

A mounting height was selected for the fixtures. The mounting height affects the spacing of the fixtures. Because the cost of the pole is usually more expensive than the fixture, the goal in lighting design is to limit the number of poles on a site.

90.1-2010 includes a requirement to turn off 30\% of parking lot lights during non-business hours, or as an alternative, any time after 15 minutes of inactivity as described above. . For this analysis, the 30\% reduction during non-business hours was assumed to be the compliance path. 
Final costs were determined to circuit (provide power) the fixtures. 90.1-2007 designs assumed that all fixtures turn on and off at the same time. 90.1-2010 designs assumed a lighting curfew and therefore have two circuits so that some lights can be extinguished at the designated times. Sample layouts were created to approximate the amount of conduit needed in the parking lot. RS Means Electrical Cost Data 2012 costs for conduit in slab were used.

\section{Entrances}

The number of doors and the lighting power allowances were developed for the prototypes in were described in Energy and Cost Savings Analysis of ASHRAE Standard 90.1-2010 and as described above.

Door lighting cannot be generalized the same way that parking lot lighting can be. The metrics are different (W/linear foot (lf) and $\mathrm{W} / \mathrm{ft}^{2}$, respectively). The height of the door also plays a role. Wide doors (e.g. $12 \mathrm{ft}$ ) have a higher header than regular doors (3 ft). Higher door headers require higher illuminance light sources. As lumen output increases (e.g., going from CFL to metal halide) the cost of both the fixture and the lamp increases.

Compact fluorescent lamps (CFLs) were selected as the light source over the doors. It was assumed that the fixtures over the doors were wallpacks/over door lights (a standard fixture for lighting over doors). It was assumed one fixture per door and two lamps per fixture. The total power of the light fixture was calculated and then compared to the code allowed power.

The light source for the roll-up doors was assumed to be a metal halide (probe-start for 90.1-2007 and pulse-start for 90.1-2010). These are common lamps used in lighting loading areas.

All fixtures were assumed to be mounted in roughly the same location in the 90.1-2007 and 90.12010 models and to be controlled with an astronomical time clock. Therefore, there is no difference in wiring for door lighting between the 90.1-2007 and 90.1-2010 designs in terms of wiring labor.

Astronomical time clocks typically allow manual settings as well and were assumed to be adequate to meet the 90.1-2010 added controls requirements.

\section{Façades}

Façade lighting can be used to light an architectural feature, signage, or other elements. The light source, type of light fixture, and controls are going to be affected by the elements being lighted. The costs were developed based on a generic façade area and maximum allowed lighting power as determined for the prototypes as described above. Costs were determined similarly with the same cost information sources used with the other exterior lighting.

\subsubsection{Building Envelope, Power and Other Equipment}

This section combines the cost items from the Standard 90.1 envelope, power and other equipment chapters.

Most building envelope requirements in Standard 90.1 Chapter 5 did not change between 90.1-2007 and 90.1-2010. Addenda to 90.1-2007 include adjustments to a limited set of envelope performance 
values for metal buildings (not included in the six selected prototypes) as well as provisions that impact infiltration, roof solar heat gain, and window area by wall orientation.

90.1-2007 Chapter 8, "Power," applies to all building power distribution systems. Two addenda were added that expand the coverage of power in 90.1-2010 beyond the limited mandatory design voltage drop requirements for feeder and branch circuits which were the only requirements in earlier editions of Standard 90.1. These addenda extend the regulation of power equipment and controls to address stepdown voltage transformers in buildings and to begin the regulation of receptacle loads by adding automatic controls for receptacles. Regulation of plug loads will likely grow in future editions of Standard 90.1 .

Standard 90.1, Chapter 10, "Other Equipment," regulates equipment not covered in other parts of Standard 90.1. The only "Other" equipment covered in 90.1-2007 is electric motors subject to the Energy Policy Act of 1992. Addendum 90.1-07aj expands the scope of motors covered by Standard 90.1 and increases the minimum motor efficiency values consistent with federal law and rulemaking. Addendum 90.1-07df sets requirements on elevator lights and ventilation fans. This section of this report discusses the modeling strategies for addenda 90.1-07aj and 90.1-07df. Addendum 90.1-07cv adds energy efficiency requirements for service water heating booster pumps, however, service water heating booster pumps were not specifically modeled in any of the prototypes, and no savings were quantified for addendum $90.1 \mathrm{cv}$.

\subsubsection{Addendum 90.1-07f: Cool Roofs}

Location in 90.1-2010: $\quad$ Section 5.5.3.1.1

Addenda: $\quad 90.1-07 f$

Prototypes Affected: $\quad$ All selected prototypes except small office.

90.1-2007 does not specify minimum reflectance or emittance requirements for roofs. 90.1-2010 introduces Section 5.5.3.1.1 with minimum requirements for solar reflectance and thermal emittance for certain types of roofs in climate zones 1 through 3 . The provision requires a minimum three-year-aged solar reflectance of 0.55 and a minimum three-year-aged thermal emittance of 0.75 for roofs in climate zones 1 through 3.

Average incremental material costs were estimated for a typical ethylene propylene diene monomer (EPDM) and thermoplastic polyolefin (TPO) that does not meet the 90.1-2010 requirements compared to the same corresponding materials that do meet the requirements. Labor was assumed to be the same for both 90.1-2007 and 90.1-2010 cases. The TPO membrane with the higher reflectance requirements added no cost. The EPDM requires a special finish to meet the requirements which added $\$ 0.15 / \mathrm{ft}^{2}$. The source for these incremental costs is DOE Building Technologies Guidelines for Selecting Cool Roofs (DOE 2010).

Costs were applied for selected climate subzones 2A, 3A, and 3B for all selected prototypes except the small office. The small office includes a roof over a ventilated attic and is exempt from the requirement. 


\subsubsection{Vestibules}

Location in 90.1-2010: $\quad$ Section 5.4.3.4

Addendum: $\quad 90.1-07 q$

Prototypes Affected: $\quad$ Small Office, climate subzone 4A only

90.1-2007 includes requirements for building entrances to include vestibules. Multiple exceptions under 5.4.3.4 are provided including exception e. for buildings located in climate zone 3 or 4, less than four stories above grade, and under 10,000 $\mathrm{ft}^{2}$. Standard 90.1-2010 modifies the exception so that climate zone 4 is no longer excluded.

90.1-2007 and 90.1-2010 do not define the dimensions of the outer entry and the inner entry of the vestibule. They do require that the minimum distance from the front entrance to the inner entrance be seven feet. The outer entry for both the 90.1-2007 and 90.1-2010 models was assumed to be two swinging glazed doors each $3 \mathrm{ft}$ by $7 \mathrm{ft}$, with surrounding glazing resulting in a total entry $9 \mathrm{ft}$ high by $12 \mathrm{ft}$ wide. The inner entry of the vestibule was assumed to have the same dimensions. The side walls of the vestibule were assumed to be the same in both the 90.1-2007 and 90.1-2010. The minimum size vestibule was assumed to be accommodated by reducing the dimensions of a lobby assumed to be included in the 90.12007 case without reducing usable floor space.

The outer entry was assumed to be the same for both the 90.1-2007 and 90.1-2010 cases. The vestibule was assumed to be unheated in climate subzone 4A. Under 90.1-2010, with an unheated vestibule the inner entry of the vestibule only needs to meet the glazing performance requirements for a semi-heated space, a u-factor of $1.2 \mathrm{Btu} / \mathrm{h} \cdot \mathrm{ft}^{2}$ for climate subzone $4 \mathrm{~A}$, which can be met by single glazing in a metal frame without thermal break. The framing system in both cases was assumed to be storefront.

The incremental cost estimate included the cost of aluminum-framed store-front entrance with 6' X 7' entry. Costs were based on RS Means Building Construction Cost Data 2012 (RS Means 2012c).

\subsubsection{Air Barrier}

Location in 90.1-2010: $\quad$ Section 5.4.3.1

Addendum:

90.107bf

Prototypes Affected: $\quad$ All six selected prototypes

90.1- 2007, Section 5.4.3.1, requires building envelope sealing at all joints and gaps around windows, doors, junctions between wall, roofs, and floors, around penetrations and any other openings to have continuous air barrier design, installation, materials, and assemblies. 90.1-2007 Section 5.4.3.2 of 90.12007 requires that air leakage of fenestrations and doors shall be determined according to National Fenestration Rating Council (NFRC) 400 (NFRC 2004) and shall not exceed $1.0 \mathrm{CFM} / \mathrm{ft}^{2}$ for glazed swinging and revolving doors, and $0.4 \mathrm{ft}^{2}$ for all other fenestration and doors.

90.1-2010 increases the stringency of these requirements. 90.1-2010 Section 5.4.3.1 requires the building envelope to be designed and constructed with a continuous air barrier. The definition added to 
90.1-2010 for a continuous air barrier is "the combination of interconnected materials, assemblies, and sealed joints and components of the building envelope that minimize air leakage into or out of the building envelope." No specific leakage rate or testing is required. There are some additional air barrier design requirements, and a section on materials such as plywood that are required to meet a maximum air leakage rate under a pressure differential of 0.3 in. w.g. consistent with currently available materials. Members of the 90.1 Envelope Subcommittee supported the interpretation that a continuous membrane air sealing system is not required and that the requirement primarily increases quality assurance and quality control (QA/QC) of the building air sealing.

The additional activity required to increase QA/QC relative to that needed to meet 90.1-2007 is not defined by Standard 90.1-2010. However, it is clear that compliance with this provision requires improved design and construction details. This can best be assured by review and oversight of those processes. As an approximation, the cost of this activity was estimated as a portion of the cost of building envelope commissioning. Since the 90.1-2010 requirement does not require testing the infiltration level, blower door and other testing costs that are often part of building envelope commissioning are excluded. This estimate does not mean that building envelope commissioning is required; it is a proxy for estimating the additional QA/QC effort.

Two commissioning firms shared views about the cost and scope of envelope commissioning which includes involvement throughout design such as development of owner requirements, and design reviews, and throughout construction including review of submittals, and frequent site inspections during the core air barrier installation period. Both commissioning firms emphasized that air sealing is only a portion of building envelope commissioning, and that moisture control is an equal or larger focus of the effort. The air sealing and water and moisture control are integrated and any separation is approximate.

One commissioning firm provided a total building envelope commissioning cost of $\$ 0.25 \mathrm{ft}^{2}$ to $\$ 0.45 / \mathrm{ft}^{2}$ of building floor area (without physical testing) for a range of building sizes with about $25 \%$ of that focused on air sealing, with the rest focused primarily on water and moisture control (Draper et al. 2012). The other commissioning agent emphasized that the costs do not vary substantially with building size and provided an estimate on the order of $\$ 60,000$ for mid-range size and moderate complexity buildings and an estimate that about $50 \%$ of that is associated with air sealing (Aldous 2012). Costs per square foot are higher for smaller buildings as there are fixed costs to provide the basic level of service including reporting, meetings, and site visits. Costs are higher for more complex buildings such as laboratories and hospitals with tighter requirements for pressurization and air changes.

A base cost of $\$ 10,000$ plus $\$ 0.40 / \mathrm{ft}^{2}$ for envelope commissioning was defined as the starting point to determine the added envelope sealing QA/QC costs. This was adjusted to approximate the proportion of envelope commissioning associated with air sealing, and the incremental quality assurance to meet 90.12010 rather than 90.1-2007 which is a fraction of the cost of envelope commissioning. A cost of $\$ 1,000$ plus $\$ 0.04 / \mathrm{ft}^{2}$ was estimated. The costs were included under labor, not commissioning, since the envelope commissioning was simply used as an approximation in the estimate, and the QA/QC effort was assumed to be part of the construction effort, not a separate effort.

\subsubsection{Air Leakage for Fenestration and Doors}

Location in 90.1-2010: $\quad$ Section 5.4.3.2 
Addendum: $\quad$ 90.1-07am

Prototypes Affected: $\quad$ All six selected prototypes

90.1-2007 Section 5.4.3.2 requires that air leakage of fenestrations and doors shall be determined according to National Fenestration Rating Council (NFRC) 400 (NFRC 2004) and shall not exceeded 1.0 $\mathrm{CFM} / \mathrm{ft}^{2}$ for glazed swinging and revolving doors, and $0.4 \mathrm{ft}^{2}$ for all other fenestration and doors, with an exception for site-built windows which have no leakage requirements.

90.1-2010 increases the stringency of these requirements. Air leakage requirements for doors and windows in 90.1-2010 vary by type of window. Listed here are the leakage values for types with cost estimates in this analysis. See 90.1-2010 Section 5.4.3.2 for testing methods.

- Curtain wall and storefront: $0.06 \mathrm{CFM} / \mathrm{ft}^{2}$

- Skylights: $0.3 \mathrm{CFM} / \mathrm{ft}^{2}$ or $0.5 \mathrm{CFM} / \mathrm{ft}^{2}$ depending on testing method with $0.3 \mathrm{CFM} / \mathrm{ft}^{2}$ assumed to provide a reduction in leakage from the $0.4 \mathrm{CFM} / \mathrm{ft}^{2}$ required in $90.1-2007$

- All other products: $0.2 \mathrm{CFM} / \mathrm{ft}^{2}$ or $0.3 \mathrm{CFM} / \mathrm{ft}^{2}$ depending on testing method

For all of the prototypes, door area is a small fraction of window area, and the door area is treated as part of the window area for simplicity.

90.1 Envelope Subcommittee members indicated that the air leakage requirements in 2010 reflect common practice that has been in place for many years before 90.1-2007 for most products. In practice, building projects in states adopting the newer Standard 90.1 will not see an increase in project costs for this provision. However, the modeled energy savings reflects this change being incorporated in Standard 90.1, therefore a cost estimate was developed. Determining the cost difference was difficult with no window products available applicable to the prototype models that do not meet the current air leakage requirements.

A curtain wall window manufacturer and supplier's technical expert said that air leakage has been tightened over time for two reasons unrelated to specific air leakage standards, 1) reduced u-factors in energy codes have required reduced air leakage as u-factor testing is affected by leakage rates, 2)

moisture infiltration and concerns about mold and associated liability (Best 2012). The changes have been achieved primarily in design, not manufacturing. The technical expert estimated that this engineering effort translates into an average of around $\$ 0.05 / \mathrm{ft}^{2}$ to $\$ 0.10 / \mathrm{ft}^{2}$ of window area. This cost is related to the volume of project sales, which is considerably higher for manufactured windows than for curtain wall systems, and the change in leakage rates for manufactured windows is smaller since curtain wall systems are exempt in 90.1-2007. This cost is estimated for all of the windows as an incremental material cost of $\$ 0.05 / \mathrm{ft}^{2}$ of window area.

\subsubsection{Daylighting and Skylights}

Location in 90.1-2010: $\quad$ Section 5.4.3.2

Addenda: $\quad$ 90.1-07al and 90.1-2007dd

Prototypes Affected: $\quad$ Standalone Retail 
90.1-2007, Chapter 9, “Lighting,” and Chapter 5, “Building Envelope,” do not specify requirements for minimum skylight fenestration area or minimum daylight area. 90.1-2010 Sections 5.5.4.2.3 introduces a requirement for minimum toplighting daylit area which has the effect of requiring a certain area of skylights in some space types. The minimum daylit area required is half of the floor area that is subject to the requirement. The requirement applies to enclosed spaces 5,000 $\mathrm{ft}^{2}$ or larger, with ceiling heights greater than $15 \mathrm{ft}$ directly under a roof with a variety of specific space types. These provisions are related to the daylighting control requirements in 90.1-2010 Sections 9.4.1.3, and 9.4.1.4 as described in Section 4.2.2.3 in this report.

The Standalone Retail prototype is the only one of the selected prototype that is required to add skylights under this requirement. The Primary School multipurpose room is subject to this requirement, but the baseline includes full coverage of skylights already for the 90.1-2007 with no change for 90.12010.

The area of skylights required for the Standalone Retail prototype is $184 \mathrm{ft}^{2}$. The 90.1-2007 models already include $72 \mathrm{ft}^{2}$ of skylights. The development of this area is detailed in Energy and Cost Savings Analysis of ASHRAE Standard 90.1-2010. The 90.1-2010 required skylight u-factor is either 1.98 or 1.17 $\mathrm{Btu} / \mathrm{h} \cdot \mathrm{F}^{\circ}$ for the selected climate locations. Double glazed skylights with no thermal break in the frame meet the range of minimum u-factors. Single glazed and plastic dome skylights were not included although these are possible for climate subzone 2A only. The cost estimator determined that double glazed skylights with no thermal break are not available. Double glazed skylights with thermally broken frame and integral curb were used for the cost estimate with costs provided by the cost estimator.

\subsubsection{Addendum 90.1-07o: Transformers}

Location in 90.1-2010: $\quad$ Section 8.1.2

Addendum: $\quad 90.1-07$ o

Prototypes Affected: $\quad$ Large Office and Primary School

90.1-2007 does not include any requirements for low voltage dry-type transformers which are used in many commercial buildings to lower the primary voltage of the electrical service provided by the utility company from 277 volts (single phase) or 480 volts (three phase) to 120 volts (single phase) or 208 volts (three phase). 90.1-2010 introduces minimum efficiencies for this type of transformer as required under the Energy Policy Act of 2005 (EPAct) and described in Energy and Cost Savings Analysis of ASHRAE Standard 90.1-2010.

The quantity and size of the transformers for each prototype was developed for the cost estimate. The 90.1-2010 energy savings analysis calculated electricity savings based on the incremental efficiency of transformers with efficiency prior to implementation of the EPAct efficiency requirements applied to a calculated wattage of transformer connected loads. The total transformer load is described in Energy and Cost Savings Analysis of ASHRAE Standard 90.1-2010.

The specific size transformers needed for the cost estimate were not determined. The assumed transformer sizes are:

- Large Office two $112.5 \mathrm{kVa}$ and two $150 \mathrm{kVa}$ not assigned to any specific area 
- Primary School three $75 \mathrm{kVa}$, each serving one classroom wing, and one $150 \mathrm{kVa}$ for the rest of the building.

For the cost estimate, transformer costs for today's efficiency transformers (that meet EPAct 2005) for two manufacturers were collected by the cost estimator. The manufacturers provided costs for 3-phase aluminum wound transformers. The efficiency of older transformers was assumed to be consistent with the analysis presented in Energy and Cost Savings Analysis of ASHRAE Standard 90.1-2010. For reference, analysis for $75 \mathrm{kVA}$ transformer used a base 96.6\% efficiency versus $98.2 \%$ for 90.1-2010.

Based on information from the two transformer manufacturers, the cost estimate for the 90.1-2007 case was 5\% less for material costs compared to the 90.1-2010 efficiency transformers. Only material costs are shown, labor is the same for 90.1-2007 and 90.1-2010. Note that in reality, projects will not see an increase in transformer costs due to implementing 90.1-2010 as the code for a jurisdiction, as the price difference was absorbed years ago and the lower efficiency units are not available.

\subsubsection{Plug Receptacle Control}

Location in 90.1-2010: $\quad$ Section 8.4.2

Addendum: $\quad$ 90.1-07bs

Prototypes Affected: $\quad$ Small Office, Large Office, Standalone Retail and Primary School

90.1-2007 does not require controls for plug receptacle loads. 90.1-2010 Section 8.4.2 requires 50\% of 120 volt 15 and 20 amp receptacles including those in modular partitions in private and open offices, and computer classrooms to have automatic controls to turn off power to these receptacles when spaces served are unoccupied based on the operating schedule, occupancy sensors or interconnection with a security system. The cost estimate was based on occupancy sensor control.

All receptacle loads in the affected space types were included. The number of receptacles affected is based on $50 \%$ of the power serving the affected areas assuming $50 \%$ of the power is used by equipment connected to the controlled receptacles. The number of receptacles is determined by assuming 33 $\mathrm{W} /$ receptacle in all office areas, and $120 \mathrm{~W} /$ receptacle for the primary school computer classroom. Each control zone is assumed to include 16 receptacles, 8 controlled and 8 uncontrolled.

Costs for 90.1-2007 include wiring and installation of conventional receptacles without controls. Costs for 90.1-2010 include additional wiring for controlled receptacles to power pack controller, power pack controllers and occupancy sensors. Smaller zones already include occupancy sensor control for lighting; for these, a bare contact is provided instead of occupancy sensor.

\subsubsection{Motor Efficiency}

Location in 90.1-2010: $\quad$ Section 10.4.1

Addendum: $\quad 90.1-07 a j$

Prototypes Affected: $\quad$ Large Office, Standalone Retail, Primary School, Small Hotel 
90.1-2007 Section 10.4.1 provides minimum motor efficiency requirements. The requirements apply to motors covered in the Energy Policy Act of 1992 and include motors from 1 to 200 hp including motors typically used for HVAC equipment.

90.1-2010 Section 10.4.1 requires higher efficiency for these types of motors manufactured based on the requirements of the Energy Independence and Security Act of 2007. Other provisions do not affect this cost estimate.

The cost estimate was for the full range of regulated motor sizes from 1 to $100 \mathrm{hp}$. The 90.1-2010 costs were estimated from current motors. The cost estimator's discussion with a motor manufacturer's representative indicated that the impact on motor cost when the federal change went into effect was about a $5 \%$ increase. This was due to increase in materials, including copper, and to ramping up production of the premium efficiency motors they were already making. The cost estimate for the 90.1-2007 case reflects a 5\% discount from the current prices.

Motors with the older efficiency are not available and have not been for years as manufacturer's complied with the federal requirements. This provision will not increase projects costs as it is adapted into state and local codes, but the 90.1 energy savings analysis, focused on the changes incorporated into Standard 90.1, included energy savings for this change.

The cost estimate was included with the HVAC equipment costs rather than with the envelope, power and other costs because the motor costs were assigned to the prototype HVAC fans, pumps, and cooling towers according to their capacity by prototype and climate with the other prototype HVAC costs. The small office and the mid-rise apartment do not have any motors of 1 hp or larger.

\subsubsection{Elevator Lighting and Ventilation}

Location in 90.1-2010: $\quad$ Section 10.4.3

Addendum: $\quad 90.1-07 d f$

Prototypes Affected: $\quad$ Large Office, Standalone Retail, Primary School, Small Hotel

90.1-2007 does not regulate elevator lighting or exhaust. 90.1-2010 requires that elevator lighting have a minimum lighting system efficacy of $35 \mathrm{~lm} / \mathrm{W}$, and that ventilation fans without air conditioning are limited to a maximum of $0.33 \mathrm{~W} / \mathrm{CFM}$ and shall include a standby mode with lights and fans off when the elevator is stopped and unoccupied for 15 minutes. The ventilation power requirement was determined to not require a change as essentially all elevator fans currently reach this target.

The cost estimate required defining the 90.1-2007 and the 90.1-2010 elevator lighting systems. Energy and Cost Savings Analysis of ASHRAE Standard 90.1-2010 includes elevator lighting information for a $28 \mathrm{ft}^{2}$ elevator. This assumes that, prior to $90.1-2010,70 \%$ of elevator lighting power was provided by incandescent lighting systems with an efficacy of $10 \mathrm{~lm} / \mathrm{W}$, with $30 \%$ of power from more efficient lighting systems with efficacy of $35 \mathrm{~lm} / \mathrm{W}$. For the 90.1-2010 case, the higher efficacy lighting system above is used for all elevator lighting. This lighting results in a 90.1-2007 LPD weighted average of 3.14 $\mathrm{W} / \mathrm{ft}^{2}$, and a 90.1-2010 LPD of $1.14 \mathrm{~W} / \mathrm{ft}^{2}$. Elevators were included in the Large Office (qty. 12), Small 
Hotel (qty. 2), and Mid-rise Apartment (qty. 1), as described in Energy and Cost Savings Analysis of ASHRAE Standard 90.1-2010.

Actual lighting equipment had to be selected to estimate costs. A PNNL lighting expert developed possible design concepts which were used for pricing. The lighting power values assumed for the 90.1 savings analysis could not be matched exactly.

90.1-2007 only, low efficacy option:

- Fixture Recessed 45 W R20, 1 lamp/fixture, 4 fixtures required

- $\quad$ Lamp 45W Halogen R20

o 385 lumens, life 2,500 hours

- System performance

o System efficacy $8.5 \mathrm{~lm} / \mathrm{W}$

o $\quad$ LPD $6.32 \mathrm{~W} / \mathrm{ft}^{2}$

o Illumination , 41.3 FC (90\% fixture efficiency, coefficient of utilization (CU) 0.85)

90.1-2007 and 90.1-2010 high efficacy option:

- Fixture Recessed 7W R20 LED, 1 lamp/fixture

o 6 fixtures required

- $\quad$ Lamp 7W R20 45W Halogen R20

o 310 lumens

o Life 45,000 hours

- System performance

o System efficacy $44 \mathrm{~lm} / \mathrm{W}$

o $\quad$ LPD $1.47 \mathrm{~W} / \mathrm{ft}^{2}$

o Illumination , 50 FC (90\% fixture efficiency, CU 0.85)

To meet the target wattage mix of 30\% low efficacy wattage, and $70 \%$ higher efficacy wattage for the 90.1-2007 case, 35\% of the quantity of fixtures were low efficacy, and $65 \%$ were high efficacy. Total cost for the 90.1-2007 case was calculated as the weighted average of the cost of the two systems, weighted by the quantity percentages above.

Replacement lives for the lamps was determined by the lamp life divided by the operating hours. For the 90.1-2007 case, the elevator lighting was assumed to be uncontrolled and be on continuously (8,760 hours annually). For the 90.1-2010 case lights were off when the elevator is not in use after a brief interval consistent with the requirement resulting in 2,154 operating hours, the same as the elevator motor operating hours as described in Energy and Cost Savings Analysis of ASHRAE Standard 90.1-2010.

\subsection{Cost Estimate Results}

The cost estimates result in incremental costs for new construction and replacement material, labor, construction equipment plus overhead and profit, as well as maintenance and commissioning.

Appendix B includes incremental cost summaries for first cost, maintenance cost, replacement costs for year 1 to 29, and residual value of items with useful lives extending beyond the 30 year analysis 
period. Residual values are discussed in Section 5.1.l. in this report, and are used in the Life-Cycle Cost Analysis in Section 5.1.1.

The cost spreadsheet (PNNL 2013) includes a worksheet with details of the summaries in Appendix $\mathrm{B}$, and a similar worksheet extending the analysis period to 40 years. The cost in a given year in these tables is a negative value if there was a replacement cost in 90.1-2007 that was greater than the replacement cost in 90.1-2010. The useful lives of corresponding items such as lamps and ballasts may not be the same for the 90.1-2007 and 90.1-2010 cases, so replacement cost values can be positive or negative throughout the 30 year period.

Table 4.8 includes total incremental first costs for each prototype and climate combination in units of total cost and cost per $\mathrm{ft}^{2}$. Table 4.9 includes estimated total building costs per $\mathrm{ft}^{2}$ from $R S$ Means Building Construction Cost Data 2012 for each prototype, and a rough indicator of the \% increase due to the incremental costs, (assuming the RS Means costs represent buildings that meet 90.1-2007). As described in Section 4.1 these costs were not adjusted for climate location.

In some cases, there is an incremental reduction in first cost in moving to 90.1-2010. This is due to reductions in HVAC equipment capacity, as well as for the interior and exterior lighting costs in some cases.

The Mid-rise Apartment incremental costs were the same for all five climate locations . The HVAC systems fall outside of any of the new requirements, and are too small to show cost impacts from changes in system capacity. The other cost categories do not vary by climate location for the Mid-rise Apartment (and in nearly all the other prototypes).

Table 4.8. Incremental Costs

\begin{tabular}{ccccccc}
\hline \multirow{2}{*}{ Prototype } & Value & $2 \mathrm{~A}$ & $3 \mathrm{~A}$ & $3 \mathrm{~B}$ & $4 \mathrm{~A}$ & $5 \mathrm{~A}$ \\
& & Houston & Memphis & El Paso & Baltimore & Chicago \\
\hline \multirow{2}{*}{ Small Office } & First Cost & $\$ 10,624$ & $\$ 8,749$ & $\$ 9,923$ & $\$ 15,112$ & $\$ 8,622$ \\
& $\$ / \mathrm{ft}^{2}$ & $\$ 1.93$ & $\$ 1.59$ & $\$ 1.80$ & $\$ 2.75$ & $\$ 1.57$ \\
Large Office & First Cost $^{2}$ & $\$ 446,971$ & $\$ 517,591$ & $\$ 451,173$ & $\$ 491,567$ & $\$ 248,074$ \\
& $\$ / \mathrm{ft}^{2}$ & $\$ 0.90$ & $\$ 1.04$ & $\$ 0.90$ & $\$ 0.99$ & $\$ 0.50$ \\
Standalone Retail & First Cost & $\$ 52,140$ & $\$ 62,041$ & $\$ 38,255$ & $\$ 69,601$ & $\$ 49,333$ \\
& $\$ / \mathrm{ft}^{2}$ & $\$ 2.11$ & $\$ 2.51$ & $\$ 1.55$ & $\$ 2.82$ & $\$ 2.00$ \\
Primary School & First Cost & $\$ 134,160$ & $\$ 149,396$ & $\$ 15,611$ & $\$ 149,768$ & $\$ 106,113$ \\
& $\$ / \mathrm{ft}^{2}$ & $\$ 1.81$ & $\$ 2.02$ & $\$ 0.21$ & $\$ 2.02$ & $\$ 1.43$ \\
\hline \multirow{2}{*}{ Small Hotel } & First Cost & $\$ 4,922$ & $-\$ 5,113$ & $-\$ 681$ & $\$ 6,571$ & $-\$ 8,766$ \\
& $\$ / \mathrm{ft}^{2}$ & $\$ 0.11$ & $-\$ 0.12$ & $-\$ 0.02$ & $\$ 0.15$ & $-\$ 0.20$ \\
\hline \multirow{2}{*}{ Mid-rise Apartment } & First Cost & $\$ 20,858$ & $\$ 20,858$ & $\$ 20,858$ & $\$ 20,858$ & $\$ 20,858$ \\
& $\$ / \mathrm{ft}^{2}$ & $\$ 0.62$ & $\$ 0.62$ & $\$ 0.62$ & $\$ 0.62$ & $\$ 0.62$ \\
\hline
\end{tabular}


Table 4.9. Comparison of Total Building Cost and Incremental Cost (per $\mathrm{Ft}^{2}$ and percentage)

\begin{tabular}{|c|c|c|c|c|c|c|}
\hline \multirow{4}{*}{ Prototype } & \multirow{3}{*}{$\begin{array}{c}\text { Building } \\
\text { First } \\
\text { Cost }\end{array}$} & \multicolumn{5}{|c|}{ Incremental Cost for 90.1-2010 } \\
\hline & & $2 \mathrm{~A}$ & 3A & 3B & $4 \mathrm{~A}$ & $5 \mathrm{~A}$ \\
\hline & & Houston & Memphis & El Paso & Baltimore & Chicago \\
\hline & $\$ / \mathrm{ft}^{2}$ & $\$ / \mathrm{ft}^{2}$ & $\$ / \mathrm{ft}^{2}$ & $\$ / \mathrm{ft}^{2}$ & $\$ / \mathrm{ft}^{2}$ & $\$ / \mathrm{ft}^{2}$ \\
\hline \multirow{2}{*}{ Small Office } & \multirow{2}{*}{$\$ 125$} & $\$ 1.93$ & $\$ 1.59$ & $\$ 1.80$ & $\$ 2.75$ & $\$ 1.57$ \\
\hline & & $1.55 \%$ & $1.27 \%$ & $1.44 \%$ & $2.20 \%$ & $1.25 \%$ \\
\hline \multirow{2}{*}{ Large Office } & \multirow{2}{*}{$\$ 158$} & $\$ 0.90$ & $\$ 1.04$ & $\$ 0.90$ & $\$ 0.99$ & $\$ 0.50$ \\
\hline & & $0.57 \%$ & $0.66 \%$ & $0.57 \%$ & $0.62 \%$ & $0.31 \%$ \\
\hline \multirow{2}{*}{ Standalone Retail } & \multirow{2}{*}{$\$ 87$} & $\$ 2.11$ & $\$ 2.51$ & $\$ 1.55$ & $\$ 2.82$ & $\$ 2.00$ \\
\hline & & $2.43 \%$ & $2.89 \%$ & $1.78 \%$ & $3.24 \%$ & $2.30 \%$ \\
\hline \multirow{2}{*}{ Primary School } & \multirow{2}{*}{$\$ 132$} & $\$ 1.81$ & $\$ 2.02$ & $\$ 0.21$ & $\$ 2.02$ & $\$ 1.43$ \\
\hline & & $1.37 \%$ & $1.53 \%$ & $0.16 \%$ & $1.53 \%$ & $1.09 \%$ \\
\hline \multirow{2}{*}{ Small Hotel } & \multirow{2}{*}{$\$ 106$} & $\$ 0.11$ & $-\$ 0.12$ & $-\$ 0.02$ & $\$ 0.15$ & $-\$ 0.20$ \\
\hline & & $0.11 \%$ & $-0.11 \%$ & $-0.01 \%$ & $0.14 \%$ & $-0.19 \%$ \\
\hline \multirow{2}{*}{$\begin{array}{l}\text { Mid-rise } \\
\text { Apartment }\end{array}$} & \multirow{2}{*}{$\$ 111$} & $\$ 0.62$ & $\$ 0.62$ & $\$ 0.62$ & $\$ 0.62$ & $\$ 0.62$ \\
\hline & & $0.56 \%$ & $0.56 \%$ & $0.56 \%$ & $0.56 \%$ & $0.56 \%$ \\
\hline
\end{tabular}




\subsection{Cost-effectiveness Analysis}

The purpose of this analysis is to determine the cost-effectiveness of the changes in Standard 90.1 from 90.1-2007 to 90.1-2010. Cost-effectiveness was analyzed using the incremental cost information presented in Chapter 4 and the energy cost information presented in this Chapter. Three cost-effectiveness measures are presented:

- Net present value life-cycle cost

- $\quad$ The SSPC 90.1 scalar method

- $\quad$ Simple payback

Annual energy costs, a necessary part of the cost-effectiveness analysis, are presented in Section 5.2, and with additional detail in Appendix C. These methods demonstrate that 90.1-2010 is cost-effective within the parameters of this analysis as shown in Section 5.3.

\subsection{Cost-effectiveness Analysis Methodology}

This report presents a cost-effectiveness assessment using a life-cycle cost analysis (LCCA) and the SSPC 90.1 scalar method for the combined changes in Standard 90.1 -2007 to 2010 for each of the 30 combinations of prototype and climate evaluated. The commonly used metric of simple payback is also included.

\subsubsection{Life-Cycle Cost Analysis}

The LCCA perspective compared the present value of incremental costs, maintenance and energy savings for each prototype building and climate location. The degree of borrowing and the impact of taxes vary considerably for different building projects, creating many possible cost scenarios. These varying costs were not included in the LCCA (but were included with the 90.1 scalar method in section 5.1.3).

The LCCA approach is based on the LCC method used by the Federal Energy Management Program (FEMP), a method required for federal projects and used by other organizations in both the public and private sectors (NIST 1995). The LCCA method consists of identifying costs (and revenues, if any) and the year in which they occur, and determining their value in present dollars (known as the net present value). This method uses fundamental engineering economics relationships about the time value of money (money today is normally worth more than money tomorrow, which is why we pay interest on a loan, and earn interest on savings). Future costs were discounted to the present based on a discount rate. The discount rate may reflect what interest rate can be earned on other conventional investments with similar risk, or in some cases, on the interest rate at which money can be borrowed for projects with the same level of risk. 
The following calculation method can be used to account for the present value of costs or revenues:

$$
\begin{aligned}
& \text { Present Value = Future Value } /(1+\mathrm{i})^{\mathrm{n}} \\
& \text { "i" is the discount rate (or interest rate in some analyses) } \\
& \text { " } \mathrm{n} \text { " is the number of years in the future the cost occurs }
\end{aligned}
$$

The present value of any cost that occurs at the beginning of year one of an analysis period is equal to that initial cost. For this analysis, initial construction costs were assumed to occur at the beginning of year one, and all subsequent costs occur at the end of the future year identified.

LCCA is used to compare different spending or investment alternatives to decide the most economical choice. Often a base case is defined against which other alternatives are compared. For this analysis, 90.1-2007 is the base case, and 90.1-2010 is the alternative. As incremental costs were used, the net present value of 90.1-2007 is zero, and the net present value of 90.1-2010 is the net present value of all of the incremental costs. If the net present value of the incremental costs is less than zero, then 90.12010 is cost-effective.

The LCCA depends on the number of years into the future that costs and revenues are considered, known as the study period. The FEMP method uses 25 years; this analysis uses 30 years. This is the same study period used for the cost-effectiveness analysis of the residential energy code, conducted by DOE and PNNL (DOE 2012d). The 30 year study period was used for this analysis for consistency with the residential code cost-effectiveness analysis, and is also widely used for life-cycle cost analysis in government and industry. The study period is also a balance between capturing the impact of future replacement costs, inflation, and energy escalation; with the increasing uncertainty of these costs the further into the future they are considered.

Several factors go into choosing the length of the study period and the residual value of equipment beyond the period of analysis is accounted for. Sometimes the useful life of equipment or materials extends beyond the study period. In this case, the longest useful life defined is 40 years for all envelope cost items, such as reflective roof membranes, as recommended by the 90.1 SSPC Envelope Subcommittee. Forty years is longer than the typical 25 or 30 year study period for life-cycle cost analysis. A residual value of the unused life of a cost item is calculated at the last year of the study period for components with longer lives than the study period, or for items whose replacement life does not fit neatly into the study period, (e.g. a chiller with a 23 year useful life). The residual value is not a salvage value, but rather a measure of the available additional years of service not yet used. The FEMP LCCA method includes a simplified approach for determining the residual value. The residual value is the proportion of the initial cost equal to the remaining years of service divided by the initial cost. For example, the residual value of the roof membrane in year 30 is (40-30)/40 or 25\% of the initial cost. The present value of the residual values applied in year 30 is included in the total present value.

The LCCA requires assumptions about what the value of money today relative to money in the future, and about how values of the cost items will change over time, such as the cost of energy and HVAC equipment. These values are determined by the analyst depending on the purpose of the analysis. In the case of the FEMP LCC method, the National Institute of Standards and Technology (NIST) periodically publishes an update of economic factors. The values published in September 2011 (NIST 2011) were used in this analysis. 
The DOE nominal discount rate is based on long-term Treasury bond rates averaged over the 12 months prior to publication of the NIST report. The nominal rate is converted to a real rate to correspond with the constant-dollar analysis approach for this analysis. The method for calculating the real discount rate from the nominal discount rate uses the projected rate of general inflation published in the most recent Report of the President's Economic Advisors, Analytical Perspectives (referenced in the NIST 2011 report without citation). The procedure would result in a discount rate for 2011 lower than the $3.0 \%$ floor prescribed in 10 CFR 436. Thus the $3.0 \%$ floor is used as the real discount rate for FEMP analyses in 2011. The implied long-term average rate of inflation was calculated as $0.9 \%$ (NIST 2011). Table 5.1 summarizes the analysis assumptions used.

Table 5.1. Life Cycle Cost Analysis Parameters

\begin{tabular}{|c|c|c|}
\hline \multirow[t]{2}{*}{ Economic Parameter } & \multicolumn{2}{|r|}{$\begin{array}{l}\text { Commercial State Cost-Effectiveness } \\
\text { Scenario } 1 \text { without Loans or Taxes }\end{array}$} \\
\hline & Value & Source \\
\hline Nominal Discount Rate ${ }^{1}$ & $3.9 \%$ & $\begin{array}{l}\text { Energy Price Indices and Discount Factors for Life-Cycle } \\
\text { Cost Analysis - 2011, NIST annual update - (2011, Rushing } \\
\text { et al.). }\end{array}$ \\
\hline Real Discount Rate ${ }^{2}$ & $3.0 \%$ & Calculated from nominal discount rate and inflation. \\
\hline Inflation $^{3}$ & $0.9 \%$ & $\begin{array}{l}\text { Energy Price Indices and Discount Factors for Life-Cycle } \\
\text { Cost Analysis - 2011, NIST annual update (2011, Rushing } \\
\text { et al.) }\end{array}$ \\
\hline Electricity and Gas Price & $\begin{array}{l}\text { \$0.0939/kWh, } \\
\text { \$1.22/therm }\end{array}$ & SSPC-90.1 \\
\hline \multirow[b]{2}{*}{ Energy Price Escalation } & $\begin{array}{l}\text { Uniform present } \\
\text { value factors }\end{array}$ & $\begin{array}{l}\text { Energy Price Indices and Discount Factors for Life-Cycle } \\
\text { Cost Analysis - 2011, NIST annual update - (2011, Rushing } \\
\text { et al.). }\end{array}$ \\
\hline & Electricity 18.88 & $\begin{array}{l}\text { The NIST uniform present value factors are multiplied by } \\
\text { the first year annual energy cost to determine the present } \\
\text { value of } 30 \text { years of energy costs and are based on a series } \\
\text { of different annual escalation rates for } 30 \text { years. }\end{array}$ \\
\hline \multicolumn{3}{|c|}{$\begin{array}{l}{ }^{1} \text { Nominal discount rate is like a quoted interest rate and takes into account expectations about the impact of } \\
\text { inflation on future values. Higher nominal rates imply higher expectations of inflation. } \\
{ }^{2} \text { Real discount rate excludes inflation so that future amounts can be defined in today's dollars in the calculations. } \\
\text { This is not a quoted interest rate. If inflation is zero, real and nominal discount rates are the same. Inflation is } \\
\text { captured in the process of using constant dollar costs and the modified discount rate. } \\
{ }^{3} \text { General inflation is the background level of price increases for all costs other than energy. This is applied to } \\
\text { replacement and maintenance costs through the real discount rate. }\end{array}$} \\
\hline
\end{tabular}

\subsubsection{Simple Payback}

Simple payback is a more basic and commonly used measure of cost-effectiveness, and is based on the number of years required for the sum of the annual return on an investment to equal the original investment. In the case, simple payback it is the total incremental first cost (described in Section 4) divided by the difference of the annual energy cost savings and the incremental annual maintenance cost. 
This method does not take into account any costs or savings after the year in which payback is reached, does not consider the time value of money, and does not take into account any replacement costs even those prior to the year simple payback is reached. The method also does not have a defined threshold for determining whether an alternative's payback is cost-effective. Decision makers generally set their own threshold for a maximum allowed payback. The simple payback perspective is reported for information purposes only in this analysis, not a basis for concluding that 90.1-2010 is cost-effective.

\subsubsection{SSPC 90.1 Scalar Method}

The SSPC 90.1 does not consider cost-effectiveness when evaluating the entire set of changes for an update to the whole Standard 90.1. However, cost-effectiveness is often considered when evaluating a specific addendum to Standard 90.1. The scalar method was developed by SSPC90.1 to evaluate the costeffectiveness of proposed changes (McBride 1995). The scalar method is an alternative life-cycle cost approach for individual energy efficiency changes with a defined useful life, taking into account first costs, annual energy cost savings, annual maintenance, taxes, inflation, fuel escalation, and financing impacts. The scalar method allows a discounted payback threshold (scalar ratio limit) to be calculated based on the measure life. As this method is designed to be used with a single measure with one value for useful life, it does not account for replacement costs. A measure is considered cost-effective if the simple payback (scalar ratio) is less than the scalar limit.

Table 5.2 shows the economic parameters used for 90.1-2010 analysis by the SSPC 90.1 for the scalar method within this report

Table 5.2. Scalar Method Economic Parameters and Scalar Ratio Limit

\begin{tabular}{lcc}
\hline Input Economic Variables - Linked & Heating & Cooling \\
\hline Economic Life - Years & 40 & 40 \\
Down Payment - \$ & 0.00 & 0.00 \\
Fuel Escalation Rate - \% & 3.7 & 3.7 \\
Discount Rate - \% & 7.0 & 7.0 \\
Loan Interest Rate - \% & 7.0 & 7.0 \\
Federal Tax Rate - \% & 34.0 & 34.0 \\
State Tax Rate - \% & 5.0 & 5.0 \\
Heating - Natural Gas Price, \$/therm & 1.22 & \\
Cooling - Electricity Price \$/kWh & & 0.1032 \\
\hline Scalar Ratio Limit & $\mathbf{2 0 . 2}$ & $\mathbf{2 0 . 2}$ \\
\hline
\end{tabular}

PNNL extended the scalar method to allow for the evaluation of multiple measures with different useful lives. This extended method takes into account the replacement of different components in the total package of 90.1-2010 changes, allowing the net present value of the replacement costs to be calculated over 40 years. The SSPC 90.1 Envelope Subcommittee uses a 40 year replacement life for envelope components and all other cost component useful lives in the cost estimate are less than that. For example, an item with a 20 year life would be replaced once during the study period. The residual value of any items with useful lives that do not fit evenly within the 40 year period is calculated using the method described in Section 5.1.1. Using this approach, the simple payback is calculated as the sum of the first costs and present value of the replacement costs, divided by the difference of the energy cost savings and incremental maintenance cost. The result is compared to the scalar ratio limit for the 40 year period, 20.2, 
as shown in Table 5.2. The packages of changes for each combination of prototype and climate location were considered cost-effective if the corresponding simple payback (scalar ratio) is less than the scalar ratio limit. The parameters shown in Table 5.2 were based on consensus of SSPC 90.1.

\subsection{Energy Costs}

Annual energy costs are a necessary part of the cost-effectiveness analysis. Annual energy costs were lower for all of the selected 90.1-2010 models compared to the corresponding 90.1-2007 models. Table 5.3 shows the annual energy cost savings, (total and cost $/ \mathrm{ft}^{2}$ ). Appendix $\mathrm{C}$ includes additional details of these costs.

Energy rates used to calculate the energy costs from the modeled energy usage were \$1.22/therm and $\$ 0.0939 / \mathrm{kWh}$. These rates were used for 90.1-2010 energy analysis, and derive from the US DOE Energy Information Administration (EIA 2006), as reported in Energy and Cost Savings Analysis of ASHRAE Standard 90.1-2010 the 30\% Goal. These were the values approved by the SSPC 90.1 for costeffectiveness for the evaluation of individual addenda during the development of 90.1-2010.

\subsection{Cost-effectiveness Analysis Results}

Table 5.4 shows the results of the cost-effectiveness analysis from all three methods, LCCA, simple payback, and scalar method. This analysis demonstrates that 90.1-2010 is cost-effective for all prototypes in each climate location relative to 90.1-2007 under the LCCA and SSPC 90.1 scalar method. As described previously, simple payback is a simpler and less robust method than the other two, is provided for information purposes only and is not truly a measure of cost-effectiveness. DOE's assessment of cost effectiveness is based on LCCA.

Table 5.3. Annual Energy Cost Savings, 90.1-2010 Compared to 90.1-2007

\begin{tabular}{|c|c|c|c|c|c|c|}
\hline \multirow[b]{2}{*}{ Prototype } & & \multicolumn{5}{|c|}{ Climate Location } \\
\hline & & $\begin{array}{c}2 \mathrm{~A} \\
\text { Houston }\end{array}$ & $\begin{array}{c}\text { 3A } \\
\text { Memphis }\end{array}$ & 3B El Paso & $\begin{array}{c}\text { 4A } \\
\text { Baltimore }\end{array}$ & $\begin{array}{c}5 \mathrm{~A} \\
\text { Chicago }\end{array}$ \\
\hline \multirow[t]{2}{*}{ Small Office } & Savings & $\$ 914$ & $\$ 919$ & $\$ 929$ & $\$ 973$ & $\$ 993$ \\
\hline & Savings $/ \mathrm{ft}^{2}$ & $\$ 0.17$ & $\$ 0.17$ & $\$ 0.17$ & $\$ 0.18$ & $\$ 0.18$ \\
\hline \multirow[t]{2}{*}{ Large Office } & Savings & $\$ 140,209$ & $\$ 129,662$ & $\$ 99,546$ & $\$ 124,939$ & $\$ 110,379$ \\
\hline & Savings/ft ${ }^{2}$ & $\$ 0.28$ & $\$ 0.26$ & $\$ 0.20$ & $\$ 0.25$ & $\$ 0.22$ \\
\hline \multirow[t]{2}{*}{ Standalone Retail } & Savings & $\$ 9,674$ & $\$ 9,605$ & $\$ 7,193$ & $\$ 8,671$ & $\$ 9,176$ \\
\hline & Savings $/ \mathrm{ft}^{2}$ & $\$ 0.39$ & $\$ 0.39$ & $\$ 0.29$ & $\$ 0.35$ & $\$ 0.37$ \\
\hline \multirow[t]{2}{*}{ Primary School } & Savings & $\$ 24,431$ & $\$ 24,754$ & $\$ 20,485$ & $\$ 24,580$ & $\$ 24,810$ \\
\hline & Savings/ft ${ }^{2}$ & $\$ 0.33$ & $\$ 0.33$ & $\$ 0.28$ & $\$ 0.33$ & $\$ 0.34$ \\
\hline \multirow[t]{2}{*}{ Small Hotel } & Savings & $\$ 6,075$ & $\$ 5,773$ & $\$ 5,514$ & $\$ 5,209$ & $\$ 5,320$ \\
\hline & Savings $/ \mathrm{ft}^{2}$ & $\$ 0.14$ & $\$ 0.13$ & $\$ 0.13$ & $\$ 0.12$ & $\$ 0.12$ \\
\hline \multirow[t]{2}{*}{ Mid-rise Apartment } & Savings & $\$ 1,608$ & $\$ 1,845$ & $\$ 1,498$ & $\$ 2,069$ & $\$ 2,593$ \\
\hline & Savings/ $\mathrm{ft}^{2}$ & $\$ 0.05$ & $\$ 0.05$ & $\$ 0.04$ & $\$ 0.06$ & $\$ 0.08$ \\
\hline
\end{tabular}


Table 5.4. Cost-effectiveness Analysis Results

\begin{tabular}{|c|c|c|c|c|c|c|}
\hline \multirow{2}{*}{ Prototype } & & \multicolumn{5}{|c|}{ Climate Zone } \\
\hline & & 2A Houston & 3A Memphis & 3B El Paso & 4A Baltimore & 5A Chicago \\
\hline \multicolumn{7}{|c|}{ Life Cycle Cost Net Savings } \\
\hline \multirow[t]{2}{*}{ Small Office } & Total & $\$ 9,500$ & $\$ 12,700$ & $\$ 10,400$ & $\$ 6,100$ & $\$ 14,300$ \\
\hline & $\$ / \mathrm{ft}^{2}$ & $\$ 1.73$ & $\$ 2.31$ & $\$ 1.89$ & $\$ 1.11$ & $\$ 2.60$ \\
\hline \multirow[t]{2}{*}{ Large Office } & Total & $\$ 1,810,000$ & $\$ 1,560,000$ & $\$ 990,000$ & $\$ 1,500,000$ & $\$ 1,730,000$ \\
\hline & $\$ / \mathrm{ft}^{2}$ & $\$ 3.63$ & $\$ 3.13$ & $\$ 1.99$ & $\$ 3.01$ & $\$ 3.47$ \\
\hline \multirow[t]{2}{*}{ Standalone Retail } & Total & $\$ 110,000$ & $\$ 95,600$ & $\$ 99,200$ & $\$ 74,000$ & $\$ 121,000$ \\
\hline & $\$ / \mathrm{ft}^{2}$ & $\$ 4.46$ & $\$ 3.87$ & $\$ 4.02$ & $\$ 3.00$ & $\$ 4.90$ \\
\hline \multirow[t]{2}{*}{ Primary School } & Total & $\$ 205,000$ & $\$ 195,000$ & $\$ 354,000$ & $\$ 197,000$ & $\$ 307,000$ \\
\hline & $\$ / \mathrm{ft}^{2}$ & $\$ 2.77$ & $\$ 2.64$ & $\$ 4.79$ & $\$ 2.66$ & $\$ 4.15$ \\
\hline \multirow[t]{2}{*}{ Small Hotel } & Total & $\$ 304,450$ & $\$ 328,000$ & $\$ 316,000$ & $\$ 284,700$ & $\$ 325,000$ \\
\hline & $\$ / \mathrm{ft}^{2}$ & $\$ 7.05$ & $\$ 7.59$ & $\$ 7.31$ & $\$ 6.59$ & $\$ 7.52$ \\
\hline \multirow[t]{2}{*}{ Mid-rise Apartment } & Total & $\$ 20,400$ & $\$ 25,500$ & $\$ 18,300$ & $\$ 30,800$ & $\$ 41,800$ \\
\hline & $\$ / \mathrm{ft}^{2}$ & $\$ 0.60$ & $\$ 0.76$ & $\$ 0.54$ & $\$ 0.91$ & $\$ 1.24$ \\
\hline \multicolumn{7}{|c|}{ Simple Payback (years) } \\
\hline Small Office & & 11.6 & 9.5 & 10.7 & 15.5 & 8.7 \\
\hline Large Office & & 3.3 & 4.1 & 4.7 & 4.1 & 2.2 \\
\hline Standalone Retail & & 5.8 & 7.0 & 5.4 & 8.8 & 5.7 \\
\hline Primary School & & 6.1 & 6.7 & 0.8 & 6.7 & 4.5 \\
\hline Small Hotel & & 0.9 & immediate & immediate & 1.4 & immediate \\
\hline Mid-rise Apartment & & 13.0 & 11.3 & 13.9 & 10.1 & 8.0 \\
\hline \multicolumn{7}{|c|}{ Scalar Ratio (Limit 20.2) ${ }^{1}$} \\
\hline Small Office & & 9.7 & 6.5 & 8.7 & 14.1 & 5.9 \\
\hline Large Office & & 4.8 & 5.8 & 7.2 & 5.9 & 3.1 \\
\hline Standalone Retail & & 6.6 & 8.2 & 5.2 & 10.1 & 6.0 \\
\hline Primary School & & 8.9 & 9.6 & 0.7 & 9.8 & 6.4 \\
\hline Small Hotel & & -23.4 & -24.8 & -24.8 & -27.3 & -27.9 \\
\hline Mid-rise Apartment & & 9.0 & 7.8 & 9.6 & 7.0 & 5.6 \\
\hline
\end{tabular}

\footnotetext{
${ }^{1}$ Scalar ratio limit for an analysis period of 40 years.
} 


\subsection{References}

AirXchange. 2012. Energy Recovery Ventilation FAQs. AirXchange. Accessed April 25, 2013 at http://www.airxchange.com/faqs.htm

ANSI/ASHRAE/IESNA. 2007. ANSI/ASHRAE/IESNA 90.1-2007, Energy Standard for Buildings Except Low-Rise Residential Buildings. American Society of Heating, Refrigerating and Air-Conditioning Engineers, Atlanta, Georgia.

ANSI/ASHRAE/IES. 2010. ANSI/ASHRAE/IES 90.1-2010, Energy Standard for Buildings Except LowRise Residential Buildings. American Society of Heating, Refrigerating and Air-Conditioning Engineers, Atlanta, Georgia.

Aldous, F. 2012. “Envelope Commissioning at WJE.” Interview with B. Thornton, PNNL on October 15, 2012.

Amazon.com. 2012. Amazon On-Line Catalog. Accessed April 25, 2013 at http://www.amazon.com/

Best, K. 2012. “Window Air Leakage.” Interview with B. Thornton, PNNL on October 10, 2012.

Briggs, R.L., R.G. Lucas, and Z.T. Taylor. 2003. "Climate Classification for Building Energy Codes and Standards: Part 1—Development Process.” ASHRAE Transactions, (1):4610-4611.

BuyLightFixtures.Com 2012. BuyLightFixtures.com On-Line Catalog. Accessed April 25, 2013 at http://www.buylightfixtures.com/

CBECS. 2003. Commercial Buildings Energy Consumption Survey 2003. Energy Information Administration, U.S. Department of Energy, Washington, D.C. Accessed April 25, 2013 at http://www.eia.doe.gov/emeu/cbecs/contents.html

Draper, D., K. Dehganian, and F. Aldous. 2012. “Envelope Commissioning at Epsten Group.” Interview with B. Thornton, PNNL on October 15, 2012.

Deru, M., K. Field, D. Studer, K. Benne, B. Griffith, P. Torcellini, B. Liu, M. Halverson, D. Winiarski, MI Rosenberg, M. Yazdazian, J. Huang, D. Crawley. 2011. U.S. Department of Energy Commercial Reference Building Models of the National Building Stock. NREL/TP-5500-46861, National Renewable Energy Laboratory, Golden, Colorado.

DOE. 2008. "Energy Conservation Program for Commercial and Industrial Equipment:

Packaged Terminal Air Conditioner and Packaged Terminal Heat Pump

Energy Conservation Standards; Final Rule”. 10 CFR Part 431. Federal Register Vol. 73, No. 195

Tuesday, October 7, 2008. Rules and Regulations pg. 58772

DOE. 2010. “Guidelines for Selecting Cool Roofs”, V1.2. U.S. Department of Energy, Washington, D.C. Accessed April 25, 2013 at http://www1.eere.energy.gov/femp/pdfs/coolroofguide.pdf

DOE. 2012A. “Building Energy Codes Program, Status of State Energy Code Adoption”. U.S.

Department of Energy, Washington, D.C. Accessed May 30, 2013 at

http://www.energycodes.gov/adoption/states 
DOE. 2012B. “Building Energy Codes Program: Determinations”. U.S. Department of Energy, Washington, D.C. April 25, 2013 at http://www.energycodes.gov/regulations/determinations

DOE. 2012c. “Commercial Prototype Building Models”. U.S. Department of Energy, Washington D.C. Accessed April 25, 2013 at http://www.energycodes.gov/development/commercial/90.1 models

DOE. 2012d. "Building Energy Codes Program, Residential IECC Cost-effectiveness Analysis and Results”. U.S. Department of Energy, Washington, D.C. Accessed April 25, 2013 at http://www.energycodes.gov/development/residential/iecc_analysis

Fimek, L. 2011. "Don’t Question Commissioning When It comes to Lighting Controls." Accessed April 25, 2013 at http://www.controleng.com/single-article/dont-question-commissioning-when-it-comes-tolighting-controls/049f2095d0.html

GoodMart. 2012. GoodMart On-Line Catalog. Accessed April 25, 2013. http://www.goodmart.com/

Grainger. 2012. Grainger On-line catalog. Accessed April 25, 2013 at.

http://www.grainger.com/Grainger/wwg/start.shtml

Jarnagin, R.E., and G.K. Bandyopadhyay. 2010. Weighting Factors for the Commercial Building Prototypes Used in the Development of ANSI/ASHRAE/IESNA 90.1-2010. PNNL-19116, Pacific Northwest National Laboratory, Richland, Washington.

NFRC. 2004. NFRC 400-2004 Procedure for Determining Fenestration Product Air Leakage. National Fenestration Ratting Council, Silver Springs, Maryland.

Nextag. 2012. Nextag On-Line Catalog. Accessed April 25, 2013 at http://www.nextag.com/replacementdamper-motor/products-html

NIST. 1995 Life-Cycle Costing Manual for the Federal Energy Management Program, NIST Handbook 135, U.S. Department of Commerce, Technology Administration and NIST.

Peterson, JC, and T Haasl. 1994. A Commissioning Cost-Effectiveness Case Study. Accessed April 25, 2013 at http://cgec.ucdavis.edu/ACEEE/1994-96/1994/VOL05/201.PDF.

PNNL. 2013. Cost-effectiveness of ASHRAE Standard 90.1-2010-Cost Estimate.xls at http://www.energycodes.gov/sites/default/files/documents/Cost-

effectiveness_of_ASHRAE_Standard_90-1-2010-Cost_Estimate.zip

Restaurant Max Inc. 2013. Online Institutional Sales of Commercial Restaurant Equipment, Supplies, and Furniture. Accessed April 25, 2013 at http://www.restaurant-services.com/hoods.htm

Richman, E.E., E. Rauch, J. Knappek, J. Phillips, K. Petty, and P. Lopez-Rangel. 2008. National Commercial Construction Characteristics and Compliance with Building Energy Codes: 1999-2007. 2008 ACEEE Summer Study on Energy Efficiency in Buildings. ACEEE Publications, Washington D.C.

RS Means. 2012A. RS Means Mechanical Cost Data, 35th Ed. Construction Publishers \& Consultants. Norwell, MA. 
RS Means. 2012B. RS Means Electrical Cost Data, 35th Ed. Construction Publishers \& Consultants. Norwell, MA.

RS Means. 2012c. RS Means Construction Cost Data, 70th Ed. Construction Publishers \& Consultants. Norwell, MA.

RS Means. 2004. RS Means Facilities, Maintenance and Repair Cost Data. Construction Publishers \& Consultants. Norwell, MA.

SMACNA. 2005. HVAC Duct Construction Standards: Metal and Flexible, $3^{\text {rd }}$. Ed. SMACNA. Chantilly, Virginia.

Thornton, BA, MI Rosenberg, EE Richman, W Wang, Y Xie, J Zhang, H Cho, VV Mendon, RA Athalye (2011). Achieving the 30\% Goal: Energy and Cost Savings Analysis of ASHRAE Standard 90.1-2010.

PNNL-20405. Pacific Northwest National Laboratory, Richland, Washington.

WSU 2005. Washington State University Extension Energy Program.. Energy Efficiency Factsheet. SUEEEP98_018, revised October 2005. Accessed April, 25, 2013 at http://www.energy.wsu.edu/Documents/BuildingCommissioning.pdf

Witte, M.J. and R.H. Henninger. 2006. "Evaluating the ability of Unitary Equipment to maintain adequate space humidity levels, Phase II” ASHRAE 1254-RP. Gard Analytics, Park Ridge, Illinois 


\section{Appendix A}

\section{Energy Modeling Prototype Building Descriptions}

This appendix is reprinted from Energy and Cost Savings Analysis of ASHRAE Standard 90.1-2010. References to report section or appendices can be found in that document. 


\section{A.1 Small Office Modeling Description}

\begin{tabular}{|c|c|c|c|c|}
\hline Item & \multicolumn{3}{|c|}{ Descriptions } & Data Source \\
\hline \multicolumn{5}{|l|}{ Program } \\
\hline \begin{tabular}{l|l} 
Vintage \\
\end{tabular} & \multicolumn{3}{|c|}{ NEW CONSTRUCTION } & \\
\hline $\begin{array}{l}\text { Location } \\
\text { (Representing } 8 \text { Climate Zones) }\end{array}$ & $\begin{array}{l}\text { Zone 1A: Miami (very hot, humid) } \\
\text { Zone 1B: Riyadh, Saudi Arabia } \\
\text { (very hot, dry) } \\
\text { Zone 2A: Houston (hot, humid) } \\
\text { Zone 2B: Phoenix (hot, dry) } \\
\text { Zone 3A: Memphis (warm, humid) } \\
\text { Zone 3B: El Paso (warm, dry) } \\
\text { Zone 3C: San Francisco (warm, } \\
\text { marine) }\end{array}$ & $\begin{array}{l}\text { Zone 4A: Baltimore (mild, humid) } \\
\text { Zone 4B: Albuquerque (mild, dry) } \\
\text { Zone 4C: Salem (mild, marine) } \\
\text { Zone 5A: Chicago (cold, humid) } \\
\text { Zone 5B: Boise (cold, dry) } \\
\text { Zone 5C: Vancouver, BC (cold, } \\
\text { marine) }\end{array}$ & $\begin{array}{l}\text { Zone 6A: Burlington (cold, } \\
\text { humid) } \\
\text { Zone 6B: Helena (cold, dry) } \\
\text { Zone 7: Duluth (very cold) } \\
\text { Zone 8: Fairbanks (subarctic) }\end{array}$ & $\begin{array}{l}\text { Selection of } \\
\text { representative climates } \\
\text { based on Briggs' paper. } \\
\text { See Reference. }\end{array}$ \\
\hline Available fuel types & \multicolumn{3}{|c|}{ gas, electricity } & \\
\hline $\begin{array}{l}\text { Building Type (Principal Building } \\
\text { Function) }\end{array}$ & \multicolumn{3}{|c|}{ OFFICE } & \\
\hline \begin{tabular}{l|l} 
& Building Prototype \\
\end{tabular} & \multicolumn{3}{|c|}{ Small Office } & \\
\hline \multicolumn{5}{|l|}{ Form } \\
\hline \begin{tabular}{l|l} 
& Total Floor Area (sq. feet) \\
\end{tabular} & \multicolumn{3}{|c|}{$5500(90.8 \mathrm{ft} \times 60.5 \mathrm{ft})$} & \\
\hline \multicolumn{4}{|l|}{ Building shape } & \\
\hline Aspect Ratio & \multicolumn{3}{|c|}{1.5} & \\
\hline Number of Floors & \multicolumn{3}{|c|}{1} & \\
\hline
\end{tabular}




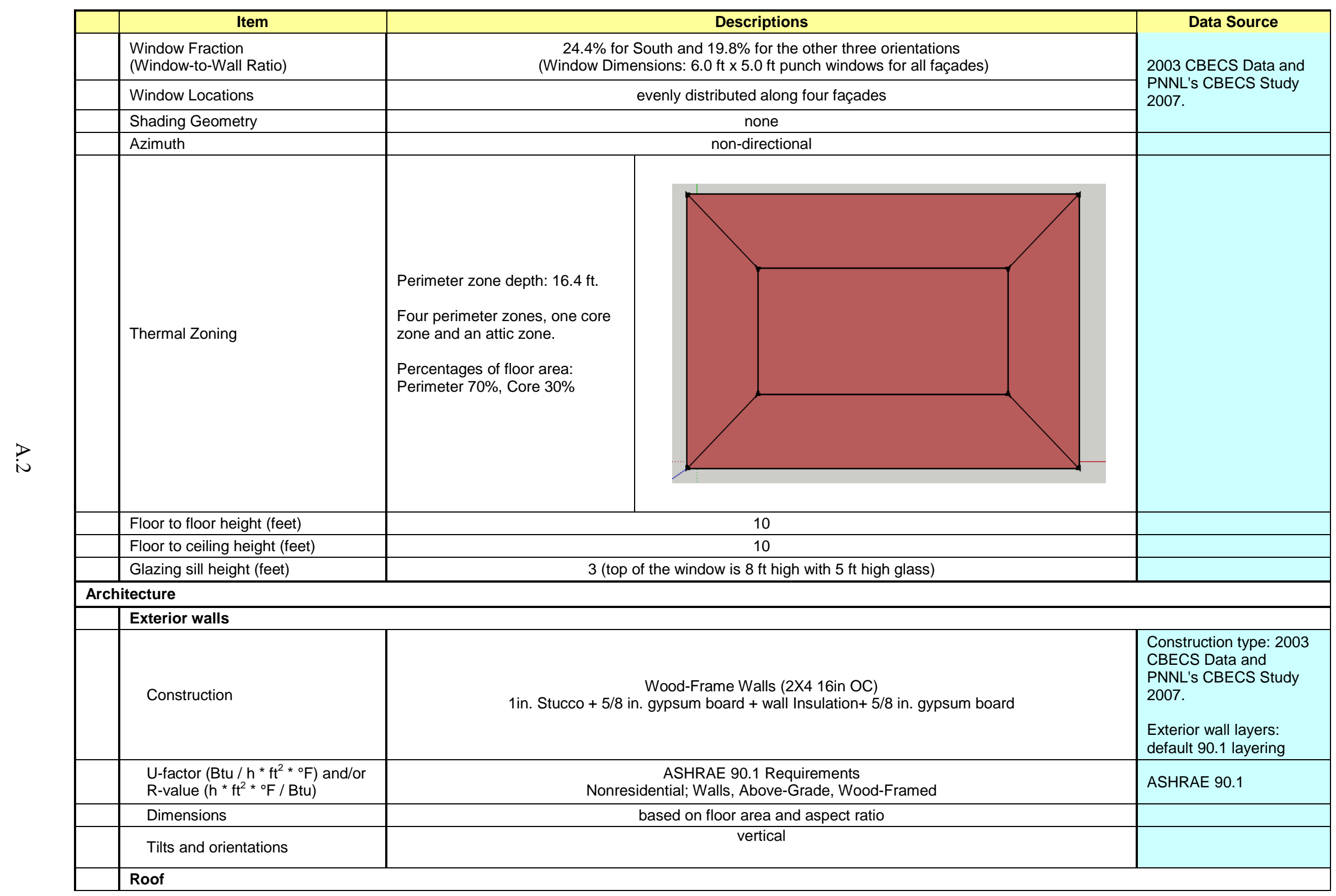




\begin{tabular}{|c|c|c|}
\hline Item & Descriptions & Data Source \\
\hline Construction & $\begin{array}{l}\text { Attic Roof with Wood Joist: } \\
\text { Roof insulation }+5 / 8 \text { in. gypsum board }\end{array}$ & $\begin{array}{l}\text { Construction type: } 2003 \\
\text { CBECS Data and } \\
\text { PNNL's CBECS Study } \\
2007 . \\
\text { Roof layers: default } 90.1 \\
\text { layering }\end{array}$ \\
\hline $\begin{array}{l}\text { U-factor }\left(\mathrm{Btu} / \mathrm{h} * \mathrm{ft}^{2} *{ }^{\circ} \mathrm{F}\right) \text { and/or } \\
\text { R-value }\left(\mathrm{h} * \mathrm{ft}^{2} *{ }^{\circ} \mathrm{F} / \mathrm{Btu}\right)\end{array}$ & $\begin{array}{l}\text { ASHRAE } 90.1 \text { Requirements } \\
\text { Nonresidential; Roofs, Attic }\end{array}$ & ASHRAE 90.1 \\
\hline Dimensions & based on floor area and aspect ratio & \\
\hline Tilts and orientations & Hipped roof: $10.76 \mathrm{ft}$ attic ridge height, $2 \mathrm{ft}$ overhang-soffit & \\
\hline Window & & \\
\hline Dimensions & punch window, each $5 \mathrm{ft}$ high by $6 \mathrm{ft}$ wide & \\
\hline Glass-Type and frame & Hypothetical window with the exact U-factor and SHGC shown below & \\
\hline U-factor (Btu $\left./ \mathrm{h} * \mathrm{ft}^{2}{ }^{2}{ }^{\circ} \mathrm{F}\right)$ & $\begin{array}{c}\text { ASHRAE 90.1 Requirements } \\
\text { Nonresidential: Vertical Glazing, 20-30\%, U fixed }\end{array}$ & ASHRAE 90.1 \\
\hline $\begin{array}{l}\text { SHGC (all) } \\
\text { Visible transmittance }\end{array}$ & $\begin{array}{l}\text { Nonresidential; Vertical Glazıng, 20-30\%, U_fixed } \\
\text { Hypothetical window with the exact U-factor and SHGC shown above }\end{array}$ & \\
\hline Operable area & 0 & $\begin{array}{l}\text { Ducker Fenestration } \\
\text { Market Data provided by } \\
\text { the } 90.1 \text { envelope } \\
\text { subcommittee }\end{array}$ \\
\hline Skylight & & \\
\hline Dimensions & Not Modeled & \\
\hline Glass-Type and frame & \multirow{4}{*}{ NA } & \\
\hline $\mathrm{U}$-factor $\left(\mathrm{Btu} / \mathrm{h} * \mathrm{ft}^{2}{ }^{\circ} \mathrm{F}\right)$ & & \\
\hline SHGC (all) & & \\
\hline Visible transmittance & & \\
\hline \multicolumn{3}{|l|}{ Foundation } \\
\hline Foundation Type & Slab-on-grade floors (unheated) & \\
\hline Construction & 8" concrete slab poured directly on to the earth & \\
\hline $\begin{array}{l}\text { Thermal properties for ground } \\
\text { level floor: } \\
\text { U-factor }\left(\mathrm{Btu} / \mathrm{h} * \mathrm{ft}^{2} *{ }^{\circ} \mathrm{F}\right) \\
\text { and/or } \\
\mathrm{R} \text {-value }\left(\mathrm{h} * \mathrm{ft}^{2}{ }^{\circ}{ }^{\circ} \mathrm{F} / \mathrm{Btu}\right)\end{array}$ & $\begin{array}{l}\text { ASHRAE 90.1 Requirements } \\
\text { Nonresidential; Slab-on-Grade Floors, unheated }\end{array}$ & ASHRAE 90.1 \\
\hline $\begin{array}{l}\text { Thermal properties for } \\
\text { basement walls }\end{array}$ & NA & \\
\hline Dimensions & based on floor area and aspect ratio & \\
\hline \multicolumn{3}{|l|}{ Interior Partitions } \\
\hline Construction & $2 \times 4$ uninsulated stud wall & \\
\hline Dimensions & based on floor plan and floor-to-floor height & \\
\hline
\end{tabular}




\begin{tabular}{|c|c|c|}
\hline Item & Descriptions & Data Source \\
\hline Internal Mass & 6 inches standard wood $\left(16.6 \mathrm{lb} / \mathrm{tt}^{2}\right)$ & \\
\hline \multicolumn{3}{|l|}{ Air Barrier System } \\
\hline Infiltration & $\begin{array}{l}\text { Peak: } 0.2016 \text { CFM/sf of above grade exterior wall surface area (when fans turn off) } \\
\text { Off Peak: } 25 \% \text { of peak infiltration rate (when fans turn on) }\end{array}$ & $\begin{array}{l}\text { Reference: } \\
\text { PNNL-18898: Infiltration } \\
\text { Modeling Guidelines for } \\
\text { Commercial Building } \\
\text { Energy Analysis. }\end{array}$ \\
\hline \multicolumn{3}{|l|}{ HVAC } \\
\hline \begin{tabular}{l|l} 
System Type \\
\end{tabular} & & \\
\hline Heating type & Air-source heat pump with gas furnace as back up & \multirow{3}{*}{$\begin{array}{l}2003 \text { CBECS Data, } \\
\text { PNNL's CBECS Study } \\
\text { 2006, and } 90.1 \\
\text { Mechanical } \\
\text { Subcommittee input. }\end{array}$} \\
\hline Cooling type & Air-source heat pump & \\
\hline Distribution and terminal units & Single zone, constant air volume air distribution, one unit per occupied thermal zone & \\
\hline \multicolumn{3}{|l|}{ HVAC Sizing } \\
\hline Air Conditioning & autosized to design day & \\
\hline Heating & autosized to design day & \\
\hline \multicolumn{3}{|l|}{ HVAC Efficiency } \\
\hline Air Conditioning & $\begin{array}{l}\text { Various by climate location and design cooling capacity } \\
\text { ASHRAE } 90.1 \text { Requirements } \\
\text { Minimum equipment efficiency for Packaged Heat Pumps }\end{array}$ & ASHRAE 90.1 \\
\hline Heating & $\begin{array}{l}\text { Various by climate location and design heating capacity } \\
\text { ASHRAE 90.1 Requirements } \\
\text { Minimum equipment efficiency for Packaged Heat Pumps and Warm Air Furnaces }\end{array}$ & ASHRAE 90.1 \\
\hline \multicolumn{3}{|l|}{ HVAC Control } \\
\hline Thermostat Setpoint & $75^{\circ} \mathrm{F}$ Cooling $/ 70^{\circ} \mathrm{F}$ Heating & \\
\hline Thermostat Setback & $85^{\circ} \mathrm{F}$ Cooling $/ 60^{\circ} \mathrm{F}$ Heating & \\
\hline Supply air temperature & Maximum 104F, Minimum 55F & \\
\hline $\begin{array}{l}\text { Chilled water } \\
\text { supply temperatures }\end{array}$ & NA & \\
\hline Hot water supply temperatures & NA & \\
\hline Economizers & $\begin{array}{l}\text { Various by climate location and cooling capacity } \\
\text { Control type: differential dry bulb }\end{array}$ & ASHRAE 90.1 \\
\hline Ventilation & ASHRAE Ventilation Standard 62.1 & $\begin{array}{l}\text { ASHRAE Ventilation } \\
\text { Standard } 62.1\end{array}$ \\
\hline Demand Control Ventilation & ASHRAE 90.1 Requirements & ASHRAE 90.1 \\
\hline
\end{tabular}




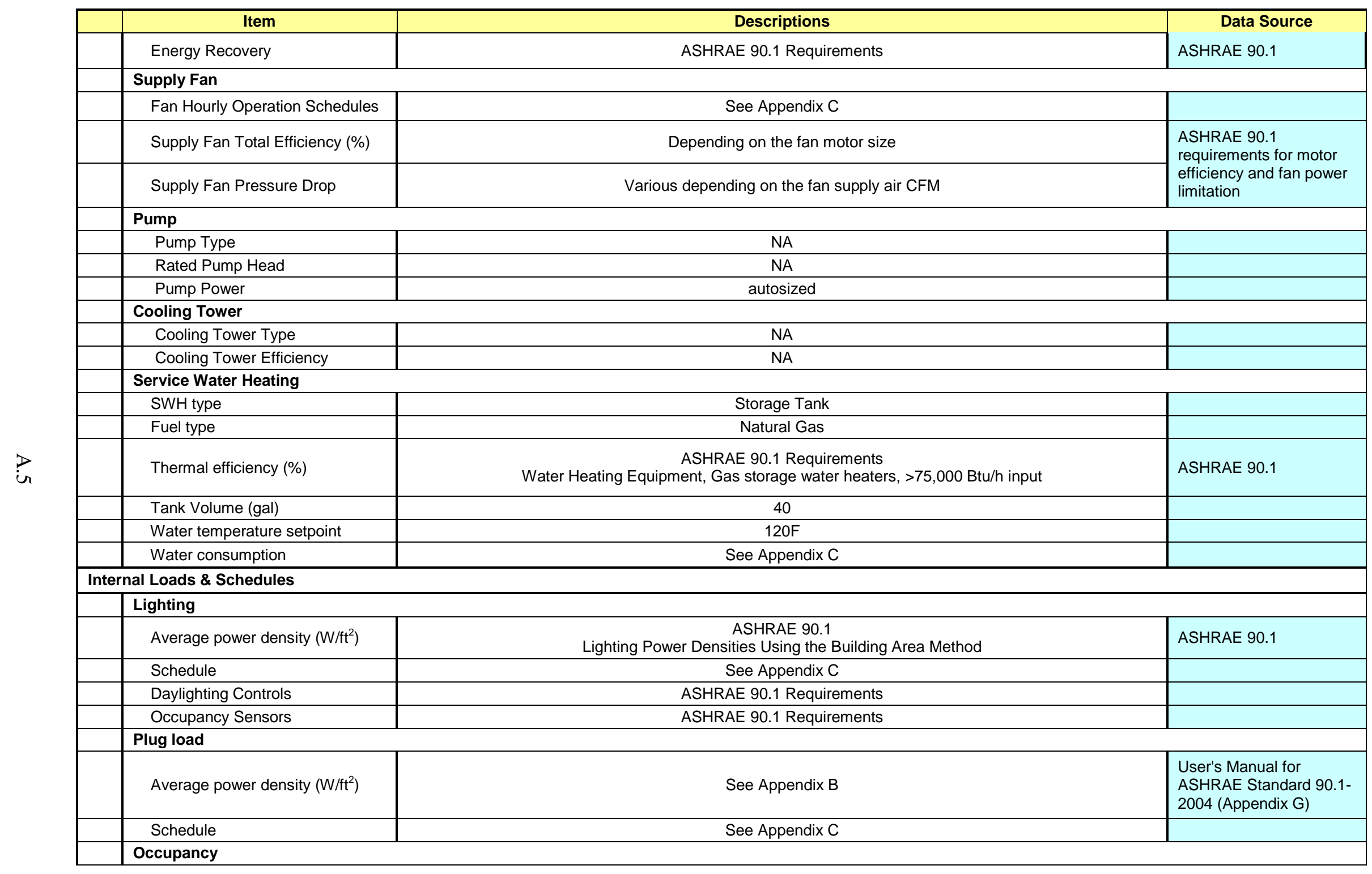




\begin{tabular}{|c|c|c|}
\hline Item & Descriptions & Data Source \\
\hline Average people & See Appendix B & $\begin{array}{l}\text { User's Manual for } \\
\text { ASHRAE Standard 90.1- } \\
2004 \text { (Appendix G) }\end{array}$ \\
\hline Schedule & See Appendix C & \\
\hline \multicolumn{3}{|l|}{ Misc. } \\
\hline \multicolumn{3}{|l|}{ Elevator } \\
\hline Peak Power & NA & \\
\hline Schedule & NA & \\
\hline \multicolumn{3}{|l|}{ Exterior Lighting } \\
\hline Peak Power (W) & 1,634 & \multirow{2}{*}{ ASHRAE 90.1} \\
\hline Schedule & See Appendix C & \\
\hline
\end{tabular}

References

Briggs, R.S., R.G. Lucas, and Z.T. Taylor. 2003. Climate Classification for Building Energy Codes and Standards:

Part 2-Zone Definitions, Maps, and Comparisons. ASHRAE Transactions 109(2).

PNNL's CBECS Study. 2007. Analysis of Building Envelope Construction in 2003 CBECS Buildings. Dave Winiarski, Mark Halverson, and Wei Jiang. Pacific Northwest National Laboratory. March 2007.

PNNL's CBECS Study. 2006. Review of Pre- and Post-1980 Buildings in CBECS - HVAC Equipment. Dave Winiarski, Wei Jiang and Mark Halverson. Pacific Northwest National Laboratory. December 2006.

Gowri K, DW Winiarski, and RE Jarnagin. 2009. Infiltration modeling guidelines for commercial building energy analysis. PNNL-18898, Pacific Northwest National Laboratory, Richland, WA. http://www.pnl.gov/main/publications/external/technical_reports/PNNL-18898.pdf 


\section{A.2 Large Office Modeling Description}

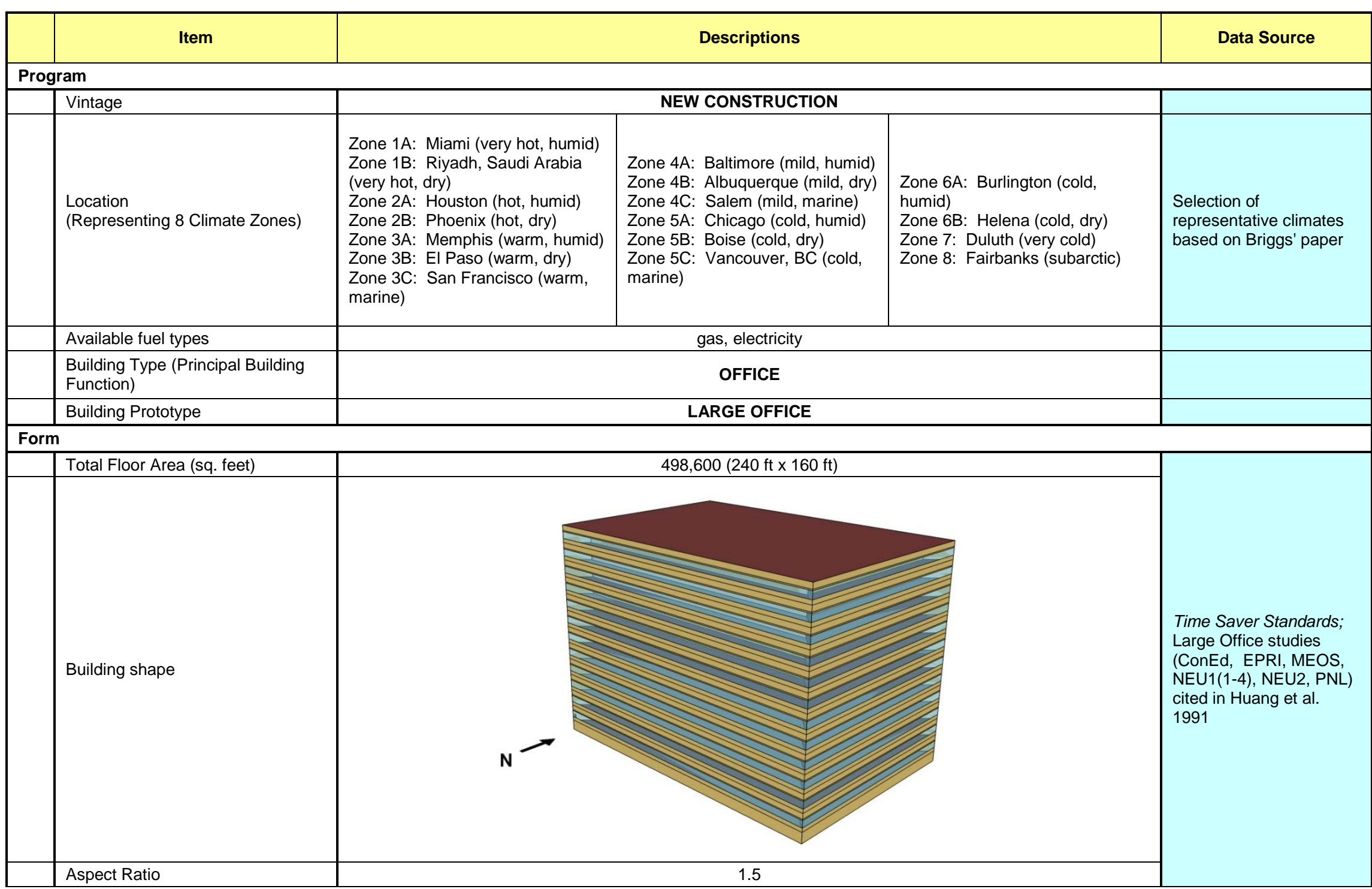




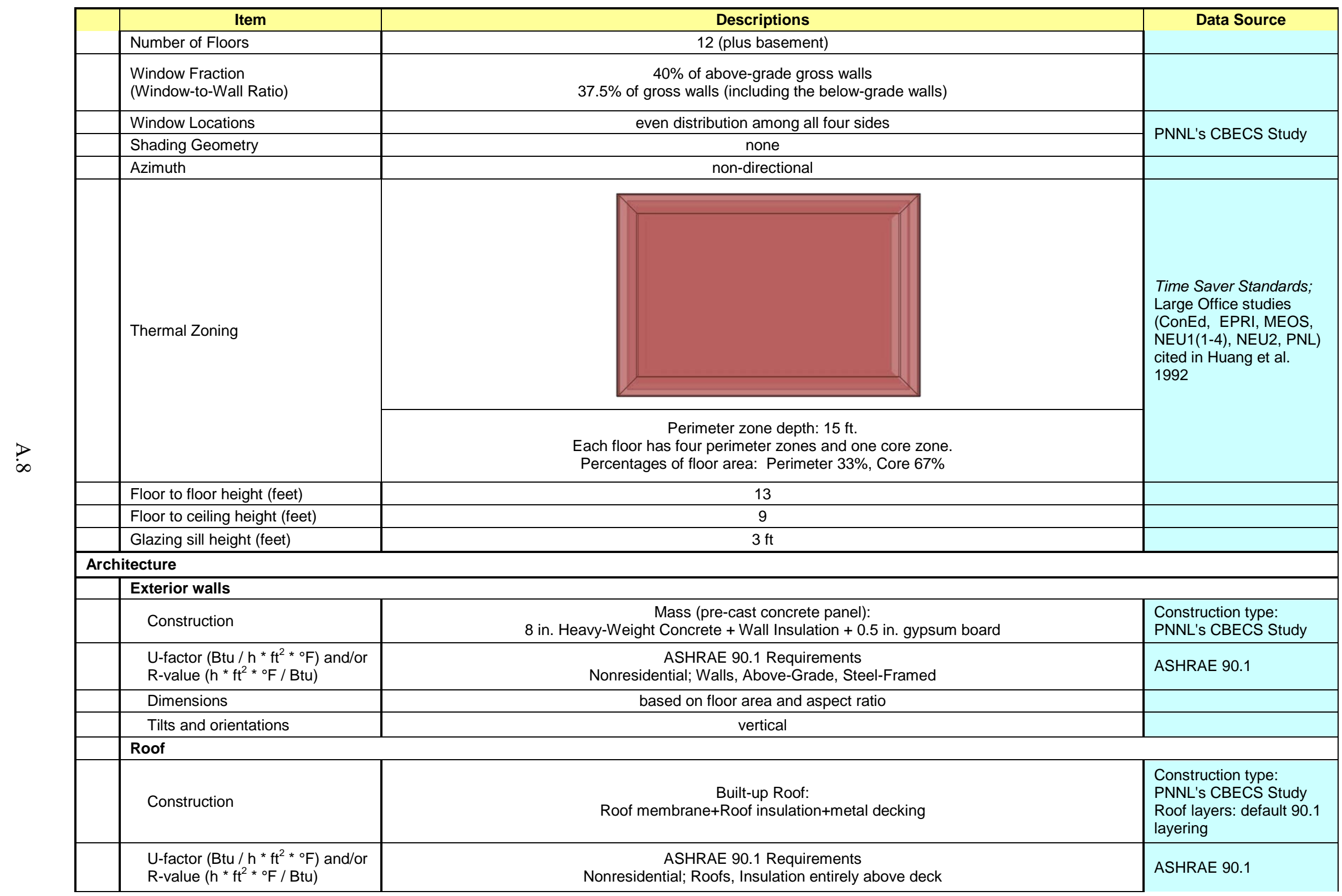




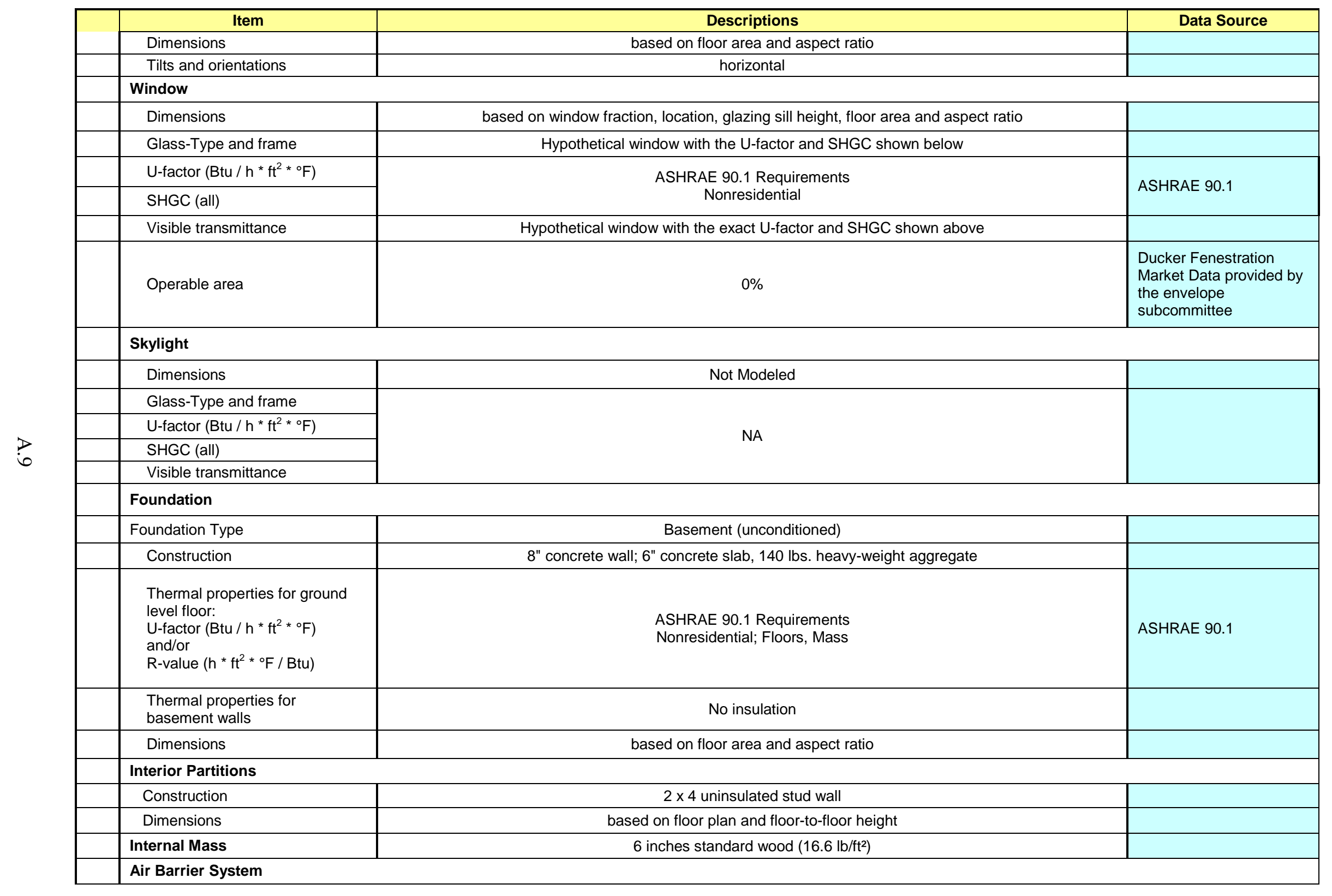




\begin{tabular}{|c|c|c|}
\hline Item & Descriptions & \multirow{2}{*}{$\begin{array}{c}\text { Data Source } \\
\text { PNNL's Infiltration Study }\end{array}$} \\
\hline Infiltration & $\begin{array}{l}\text { Peak: } 0.2016 \text { CFM/sf of above grade exterior wall surface area (when fans turn off) } \\
\text { Off Peak: } 25 \% \text { of peak infiltration rate (when fans turn on) }\end{array}$ & \\
\hline & & \\
\hline System Type & & \\
\hline Heating type & Gas boiler & \multirow{3}{*}{ PNNL's CBECS Study } \\
\hline Cooling type & Two water-cooled centrifugal chillers & \\
\hline Distribution and terminal units & $\begin{array}{l}\text { VAV terminal box with damper and hot-water reheating coil } \\
\text { Zone control type: minimum supply air at } 30 \% \text { of the zone design peak supply air. }\end{array}$ & \\
\hline \multicolumn{3}{|l|}{ HVAC Sizing } \\
\hline Air Conditioning & autosized to design day & \\
\hline Heating & autosized to design day & \\
\hline \multicolumn{3}{|l|}{ HVAC Efficiency } \\
\hline Air Conditioning & Varies by climate locations based on cooling capacity & ASHRAE 90.1 \\
\hline Heating & Varies by climate locations based on heating capacity & ASHRAE 90.1 \\
\hline \multicolumn{3}{|l|}{ HVAC Control } \\
\hline Thermostat Setpoint & $75^{\circ} \mathrm{F}$ Cooling $/ 70^{\circ} \mathrm{F}$ Heating & \multirow{2}{*}{$\begin{array}{l}\text { 90.1 Simulation Working } \\
\text { Group }\end{array}$} \\
\hline Thermostat Setback & $85^{\circ} \mathrm{F}$ Cooling $/ 60^{\circ} \mathrm{F}$ Heating & \\
\hline Supply air temperature & Maximum 110F, Minimum 52F & \\
\hline $\begin{array}{l}\text { Chilled water supply } \\
\text { temperatures }\end{array}$ & $44 \mathrm{~F}$ & \\
\hline Hot water supply temperatures & $180 \mathrm{~F}$ & \\
\hline Economizers & $\begin{array}{l}\text { Air-side economizer only in all the zones except: } \\
\qquad 1 \mathrm{~A}, 1 \mathrm{~B}, 2 \mathrm{~A}, 3 \mathrm{~A} \text {, and } 4 \mathrm{~A} \text {. }\end{array}$ & ASHRAE 90.1 \\
\hline Ventilation & ASHRAE Ventilation Standard 62.1 & $\begin{array}{l}\text { ASHRAE Ventilation } \\
\text { Standard } 62.1\end{array}$ \\
\hline Demand Control Ventilation & No & ASHRAE 90.1 \\
\hline Energy Recovery & No & ASHRAE 90.1 \\
\hline \multicolumn{3}{|l|}{ Supply Fan } \\
\hline Fan schedules & See Appendix C & \\
\hline Supply Fan Total Efficiency (\%) & $60 \%$ to $62 \%$ depending on the fan motor size & \multirow{2}{*}{ ASHRAE 90.1} \\
\hline Supply Fan Pressure Drop & Various depending on the fan supply air CFM & \\
\hline \multicolumn{3}{|l|}{ Pump } \\
\hline Pump Type & $\begin{array}{l}\text { CHW and HW: variable speed; } \\
\text { CW: constant speed }\end{array}$ & \\
\hline Rated Pump Head & $\begin{array}{l}\text { CHW: } 56 \mathrm{ft} \\
\mathrm{HW} \text { and CW: } 60 \mathrm{ft}\end{array}$ & ASHRAE 90.1 \\
\hline
\end{tabular}




\begin{tabular}{|c|c|c|}
\hline Item & Descriptions & Data Source \\
\hline Pump Power & autosized & \\
\hline Cooling Tower & & \\
\hline Cooling Tower Type & open cooling tower with two-speed fans & ASHRAE 90.1 \\
\hline Cooling Tower Power & autosized & \\
\hline Service Water Heating & & \\
\hline SWH type & Storage Tank & \\
\hline Fuel type & Natural Gas & \\
\hline Thermal efficiency (\%) & $80 \%$ & \\
\hline Tank Volume (gal) & 260 & \\
\hline Water temperature setpoint & $180 \mathrm{~F}$ & \\
\hline Water consumption & See Appendix C & \\
\hline Internal Loads \& Schedules & & \\
\hline Lighting & & \\
\hline Average power density $\left(\mathrm{W} / \mathrm{ft}^{2}\right)$ & $\begin{array}{l}\text { ASHRAE } 90.1 \\
\text { Lighting Power Densities Using the Building-Area Method }\end{array}$ & ASHRAE 90.1 \\
\hline Schedule & See Appendix C & \\
\hline Daylighting Controls & No & \\
\hline Occupancy Sensors & No & \\
\hline Plug load & & \\
\hline Average power density $\left(\mathrm{W} / \mathrm{ft}^{2}\right)$ & See Appendix B & ASHRAE 90.1 \\
\hline Schedule & See Appendix C & \\
\hline Occupancy & & \\
\hline Average people & See Appendix B & $\begin{array}{l}\text { ASHRAE Ventilation } \\
\text { Standard } 62.1\end{array}$ \\
\hline Schedule & See Appendix C & \\
\hline Misc. & & \\
\hline Elevator & & \\
\hline Quantity & 12 & \\
\hline Motor type & traction & $\begin{array}{l}\text { DOE Commercial } \\
\text { Reference Building TSD }\end{array}$ \\
\hline Peak Motor Power (W/elevator) & 20370 & $\begin{array}{l}\text { (Deru et al. 2011) and } \\
\text { models (V1.3_5.0). }\end{array}$ \\
\hline Heat Gain to Building & Exterior & \\
\hline $\begin{array}{l}\text { Peak Fan/lights Power } \\
\text { (W/elevator) }\end{array}$ & 161.9 & $\begin{array}{l}\text { 90.1 Mechanical } \\
\text { Subcommittee, Elevator } \\
\text { Working Group }\end{array}$ \\
\hline
\end{tabular}




\begin{tabular}{|c|c|c|}
\hline Item & Descriptions & Data Source \\
\hline Motor and fan/lights Schedules & See Appendix C & $\begin{array}{l}\text { DOE Commercial } \\
\text { Reference Building TSD } \\
\text { (Deru et al. 2011) and } \\
\text { models (V1.3_5.0) and } \\
\text { Appendix DF 2007 }\end{array}$ \\
\hline \multicolumn{3}{|l|}{ Exterior Lighting } \\
\hline Peak Power (W) & 60,216 & $\begin{array}{l}\text { ASHRAE 90.1-2004; } \\
\text { PNNL study; } \\
\text { 90.1 Lighting } \\
\text { Subcommittee inputs }\end{array}$ \\
\hline Schedule & Astronomical Clock & ASHRAE 90.1-2004 \\
\hline
\end{tabular}

References

Briggs, R.S., R.G. Lucas, and Z.T. Taylor. 2003. Climate Classification for Building Energy Codes and Standards:

Part 2-Zone Definitions, Maps, and Comparisons. ASHRAE Transactions 109(2).

McGraw-Hill Companies, Inc. (2001). Time-Saver Standards for Building Types. New York, NY.

LBNL (1991). Huang, Joe, Akbari, H., Rainer, L. and Ritschard, R. 481 Prototypical Commercial Buildings for 20 Urban Market Areas, prepared for the Gas Research Institute, Chicago IL, also LBL-29798, Berkeley CA.

PNNL's CBECS Study. 2007. Analysis of Building Envelope Construction in 2003 CBECS Buildings. Dave Winiarski, Mark Halverson, and Wei Jiang. Pacific Northwest National Laboratory. March 2007.

PNNL's CBECS Study. 2006. Review of Pre- and Post-1980 Buildings in CBECS - HVAC Equipment. Dave Winiarski, Wei Jiang and Mark Halverson. Pacific Northwest National Laboratory. December 2006. 


\section{A.3 Stand-alone Retail Modeling Description}

\begin{tabular}{|c|c|c|c|c|}
\hline Item & \multicolumn{3}{|c|}{ Descriptions } & Data Source \\
\hline \multicolumn{5}{|l|}{ Program } \\
\hline \begin{tabular}{l|l} 
Vintage \\
\end{tabular} & & NEW CONSTRUCTION & & \\
\hline $\begin{array}{l}\text { Location } \\
\text { (Representing } 8 \text { Climate Zones) }\end{array}$ & $\begin{array}{l}\text { Zone 1A: Miami (very hot, humid) } \\
\text { Zone 1B: Riyadh, Saudi Arabia } \\
\text { (very hot, dry) } \\
\text { Zone 2A: Houston (hot, humid) } \\
\text { Zone 2B: Phoenix (hot, dry) } \\
\text { Zone 3A: Memphis (warm, } \\
\text { humid) } \\
\text { Zone 3B: El Paso (warm, dry) } \\
\text { Zone 3C: San Francisco (warm, } \\
\text { marine) }\end{array}$ & $\begin{array}{l}\text { Zone 4A: Baltimore (mild, } \\
\text { humid) } \\
\text { Zone 4B: Albuquerque (mild, } \\
\text { dry) } \\
\text { Zone 4C: Salem (mild, marine) } \\
\text { Zone 5A: Chicago (cold, humid) } \\
\text { Zone 5B: Boise (cold, dry) } \\
\text { Zone 5C: Vancouver, BC (cold, } \\
\text { marine) }\end{array}$ & $\begin{array}{l}\text { Zone 6A: Burlington (cold, } \\
\text { humid) } \\
\text { Zone 6B: Helena (cold, dry) } \\
\text { Zone 7: Duluth (very cold) } \\
\text { Zone 8: Fairbanks (subarctic) }\end{array}$ & $\begin{array}{l}\text { Selection of } \\
\text { representative climates } \\
\text { based on Briggs' paper. } \\
\text { See Reference. }\end{array}$ \\
\hline Available fuel types & \multicolumn{3}{|c|}{ gas, electricity } & \\
\hline $\begin{array}{l}\text { Building Type (Principal Building } \\
\text { Function) }\end{array}$ & \multicolumn{3}{|c|}{ RETAIL } & \\
\hline Building Prototype & \multicolumn{3}{|c|}{ Standalone Retail } & \\
\hline \multicolumn{5}{|l|}{ Form } \\
\hline \begin{tabular}{l|l} 
& Total Floor Area (sq. feet)
\end{tabular} & & $24695(178 \mathrm{ft} \times 139 \mathrm{ft})$ & & \\
\hline \multicolumn{5}{|l|}{ Building shape } \\
\hline Aspect Ratio & \multicolumn{3}{|c|}{1.28} & \\
\hline
\end{tabular}




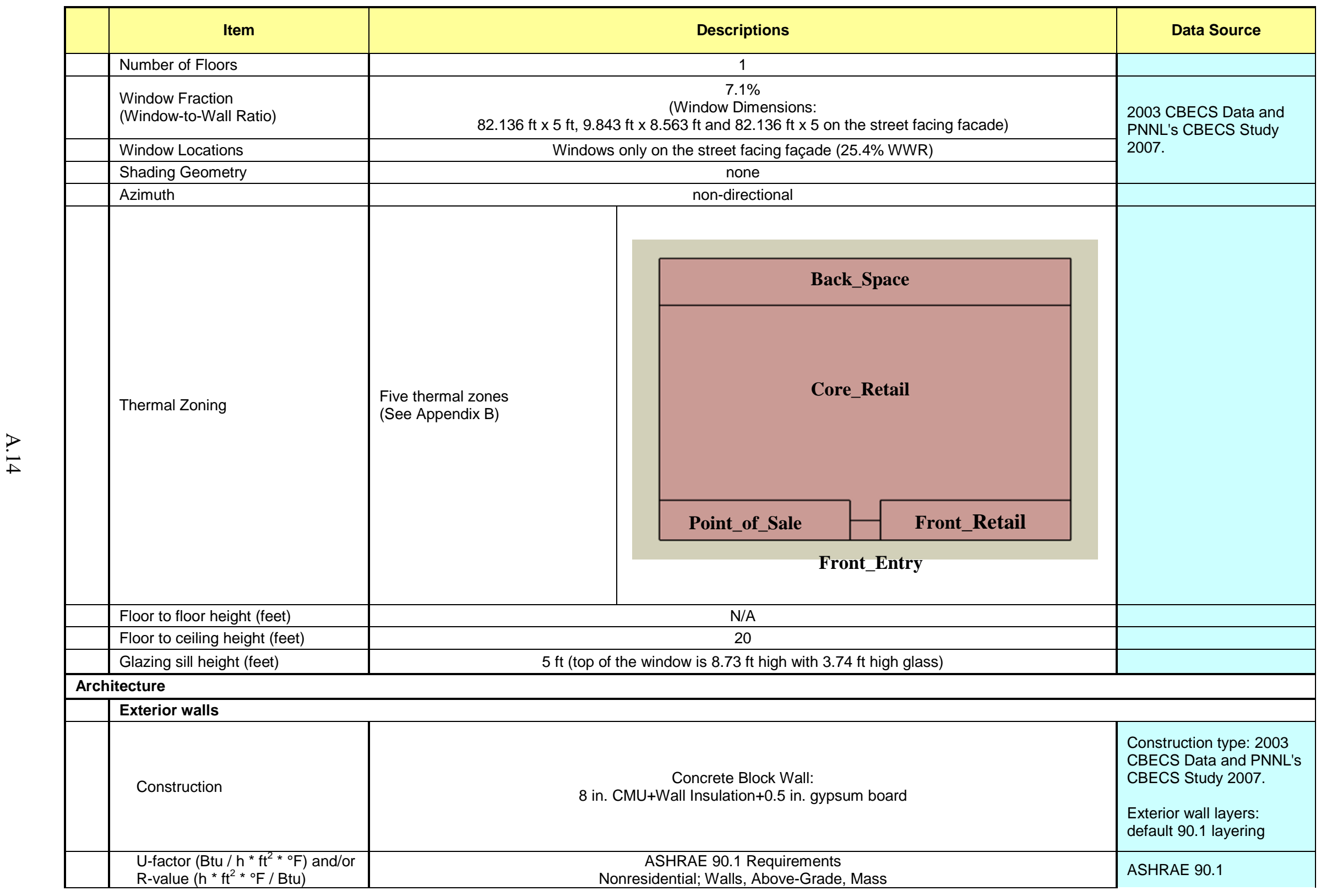




\begin{tabular}{|c|c|c|}
\hline Item & Descriptions & Data Source \\
\hline Dimensions & based on floor area and aspect ratio & \\
\hline Tilts and orientations & Vertical & \\
\hline \multicolumn{3}{|l|}{ Roof } \\
\hline Construction & $\begin{array}{l}\text { Built-up Roof: } \\
\text { Roof membrane+Roof insulation+metal decking }\end{array}$ & $\begin{array}{l}\text { Construction type: } 2003 \\
\text { CBECS Data and PNNL's } \\
\text { CBECS Study } 2007 . \\
\text { Roof layers: default } 90.1 \\
\text { layering }\end{array}$ \\
\hline $\begin{array}{l}\text { U-factor }\left(\mathrm{Btu} / \mathrm{h} * \mathrm{ft}^{2} *{ }^{\circ} \mathrm{F}\right) \text { and } / \text { or } \\
\text { R-value }\left(\mathrm{h} * \mathrm{ft}^{2} *{ }^{\circ} \mathrm{F} / \mathrm{Btu}\right)\end{array}$ & $\begin{array}{c}\text { ASHRAE 90.1 Requirements } \\
\text { Nonresidential; Roofs, Insulation entirely above deck }\end{array}$ & ASHRAE 90.1 \\
\hline Dimensions & based on floor area and aspect ratio & \\
\hline Tilts and orientations & horizontal & \\
\hline \multicolumn{3}{|l|}{ Window } \\
\hline Dimensions & based on window fraction, location, glazing sill height, floor area and aspect ratio & \\
\hline Glass-Type and frame & Hypothetical window with the exact U-factor and SHGC shown below & \\
\hline $\begin{array}{l}\left.\text { U-factor (Btu } / \mathrm{h} * \mathrm{ft}^{2} *{ }^{\circ} \mathrm{F}\right) \\
\text { SHGC (all) }\end{array}$ & $\begin{array}{c}\text { ASHRAE 90.1 Requirements } \\
\text { Nonresidential; Vertical Glazing, 20.1-30.0\% }\end{array}$ & ASHRAE 90.1 \\
\hline Visible transmittance & Hypothetical window with the exact U-factor and SHGC shown above & $\begin{array}{l}\text { Ducker Fenestration } \\
\text { Market Data provided by } \\
\text { the } 90.1 \text { envelope } \\
\text { subcommittee }\end{array}$ \\
\hline Operable area & $2 \%$ & $\begin{array}{l}\text { Ducker Fenestration } \\
\text { Market Data provided by } \\
\text { the envelope } \\
\text { subcommittee }\end{array}$ \\
\hline \multicolumn{3}{|l|}{ Skylight } \\
\hline Dimensions & $\begin{array}{c}\text { Core Retail, } \\
\text { Rectangular skylight } \\
4 \mathrm{ft} \times 4 \mathrm{ft}=16 \mathrm{ft}^{2} \text { per skylight } \\
\text { Number of skylights and total skylight area vary according to ASHRAE 90.1 Requirements }\end{array}$ & ASHRAE 90.1 \\
\hline Glass-Type and frame & Hypothetical glass and frame meeting ASHRAE 90.1 Requirements below & \\
\hline U-factor $\left(\mathrm{Btu} / \mathrm{h} * \mathrm{ft}^{2} *{ }^{\circ} \mathrm{F}\right)$ & \multirow{3}{*}{$\begin{array}{l}\text { ASHRAE 90.1 Requirements } \\
\text { Nonresidential; Skylight with Curb, Glass }\end{array}$} & \multirow{3}{*}{ ASHRAE 90.1} \\
\hline SHGC (all) & & \\
\hline Visible transmittance & & \\
\hline \multicolumn{3}{|l|}{ Foundation } \\
\hline Foundation Type & Slab-on-grade floors (unheated) & \\
\hline Construction & 6" concrete slab poured directly on to the earth with carpet & \\
\hline
\end{tabular}




\begin{tabular}{|c|c|c|}
\hline Item & Descriptions & Data Source \\
\hline $\begin{array}{l}\text { Thermal properties for ground } \\
\text { level floor: } \\
\text { U-factor }\left(\mathrm{Btu} / \mathrm{h} * \mathrm{ft}^{2} *{ }^{\circ} \mathrm{F}\right) \\
\text { and/or } \\
\text { R-value }\left(\mathrm{h} * \mathrm{ft}^{2} *{ }^{\circ} \mathrm{F} / \mathrm{Btu}\right)\end{array}$ & $\begin{array}{l}\text { ASHRAE } 90.1 \text { Requirements } \\
\text { Nonresidential; Slab-on-Grade Floors, unheated }\end{array}$ & ASHRAE 90.1 \\
\hline $\begin{array}{l}\text { Thermal properties for } \\
\text { basement walls }\end{array}$ & NA & \\
\hline Dimensions & based on floor area and aspect ratio & \\
\hline \multicolumn{3}{|l|}{ Interior Partitions } \\
\hline Construction & 0.5 in gypsum board +0.5 in gypsum board & \\
\hline Dimensions & based on floor plan and floor-to-floor height & \\
\hline Internal Mass & 6 inches standard wood $\left(16.6 \mathrm{lb} / \mathrm{ft}^{2}\right)$ & \\
\hline \multicolumn{3}{|l|}{ Air Barrier System } \\
\hline Infiltration & $\begin{array}{l}\text { Peak: } 0.2016 \text { CFM/sf of above grade exterior wall surface area (when fans turn off) } \\
\text { Off Peak: } 25 \% \text { of peak infiltration rate (when fans turn on) }\end{array}$ & $\begin{array}{l}\text { Reference: } \\
\text { PNNL-18898: Infiltration } \\
\text { Modeling Guidelines for } \\
\text { Commercial Building } \\
\text { Energy Analysis. }\end{array}$ \\
\hline \multicolumn{3}{|l|}{ HVAC } \\
\hline \begin{tabular}{l|l} 
& System Type \\
\end{tabular} & & \\
\hline Heating type & $\begin{array}{l}\text { Gas furnace inside the packaged air conditioning unit for back_space, core_retail, point_of_sale, and } \\
\text { front_retail. Standalone gas furnace for front_entry. }\end{array}$ & \multirow{3}{*}{$\begin{array}{l}2003 \text { CBECS Data, } \\
\text { PNNL's CBECS Study } \\
2006 \text {, and } 90.1 \\
\text { Mechanical } \\
\text { Subcommittee input. }\end{array}$} \\
\hline Cooling type & $\begin{array}{l}\text { Packaged air conditioning unit for back_space, core_retail, point_of_sale, and front_retail; } \\
\text { No cooling for front_entry. }\end{array}$ & \\
\hline Distribution and terminal units & $\begin{array}{l}\text { Constant air volume air distribution } \\
\text { 4 single-zone roof top units serving four thermal zones } \\
\text { ( back_space, core_retail, point_of_sale, and front_retail) }\end{array}$ & \\
\hline \multicolumn{3}{|l|}{ HVAC Sizing } \\
\hline Air Conditioning & autosized to design day & \\
\hline Heating & autosized to design day & \\
\hline \multicolumn{3}{|l|}{ HVAC Efficiency } \\
\hline Air Conditioning & $\begin{array}{c}\text { Various by climate location and design cooling capacity } \\
\text { ASHRAE } 90.1 \text { Requirements } \\
\text { Minimum equipment efficiency for Air Conditioners and Condensing Units }\end{array}$ & ASHRAE 90.1 \\
\hline Heating & $\begin{array}{l}\text { Various by climate location and design heating capacity } \\
\text { ASHRAE } 90.1 \text { Requirements } \\
\text { Minimum equipment efficiency for Warm Air Furnaces }\end{array}$ & ASHRAE 90.1 \\
\hline \multicolumn{3}{|l|}{ HVAC Control } \\
\hline Thermostat Setpoint & $75^{\circ} \mathrm{F}$ Cooling $/ 70^{\circ} \mathrm{F}$ Heating & \\
\hline Thermostat Setback & $85^{\circ} \mathrm{F}$ Cooling $/ 60^{\circ} \mathrm{F}$ Heating & \\
\hline
\end{tabular}




\begin{tabular}{|c|c|c|}
\hline Item & Descriptions & Data Source \\
\hline Supply air temperature & Maximum $104^{\circ} \mathrm{F}$, Minimum $55^{\circ} \mathrm{F}$ & \\
\hline $\begin{array}{l}\text { Chilled water supply } \\
\text { temperatures }\end{array}$ & NA & \\
\hline Hot water supply temperatures & NA & \\
\hline Economizers & $\begin{array}{c}\text { Various by climate location and cooling capacity } \\
\text { Control type: differential dry bulb }\end{array}$ & ASHRAE 90.1 \\
\hline Ventilation & ASHRAE Ventilation Standard 62.1 & $\begin{array}{l}\text { ASHRAE Ventilation } \\
\text { Standard } 62.1\end{array}$ \\
\hline Demand Control Ventilation & ASHRAE 90.1 Requirements & ASHRAE 90.1 \\
\hline Energy Recovery & ASHRAE 90.1 Requirements & ASHRAE 90.1 \\
\hline \multicolumn{3}{|l|}{ Supply Fan } \\
\hline Fan schedules & See Appendix C & \\
\hline $\begin{array}{l}\text { Supply Fan Mechanical } \\
\text { Efficiency (\%) }\end{array}$ & Various depending on the fan motor size & \multirow{2}{*}{$\begin{array}{l}\text { ASHRAE } 90.1 \\
\text { requirements for motor } \\
\text { efficiency and fan power } \\
\text { limitation }\end{array}$} \\
\hline Supply Fan Pressure Drop & Various depending on the fan supply air CFM & \\
\hline \multicolumn{3}{|l|}{ Pump } \\
\hline Pump Type & Service hot water & \\
\hline Rated Pump Heat & No & \\
\hline Pump Power & $100 \%$ eff. motor. Negligible power consumption & \\
\hline \multicolumn{3}{|l|}{ Cooling Tower } \\
\hline Cooling Tower Type & NA & \\
\hline Cooling Tower Efficiency & NA & \\
\hline \multicolumn{3}{|l|}{ Service Water Heating } \\
\hline SWH type & Storage Tank & \\
\hline Fuel type & Natural Gas & \\
\hline Thermal efficiency (\%) & $\begin{array}{l}\text { ASHRAE 90.1 Requirements } \\
\text { Water Heating Equipment, Gas storage water heaters, }>75,000 \mathrm{Btu} / \mathrm{h} \text { input }\end{array}$ & ASHRAE 90.1 \\
\hline Tank Volume (gal) & 40 & \\
\hline Water temperature setpoint & $120^{\circ} \mathrm{F}$ & \\
\hline Water consumption & $\begin{array}{l}\text { BLDG_SWH_SCH } \\
\text { See Appendix C }\end{array}$ & \\
\hline \multicolumn{3}{|l|}{ Internal Loads \& Schedules } \\
\hline \multicolumn{3}{|l|}{ Lighting } \\
\hline Average power density $\left(\mathrm{W} / \mathrm{ft}^{2}\right)$ & $\begin{array}{l}\text { ASHRAE } 90.1 \\
\text { Lighting Power Densities Using the Building Area Method }\end{array}$ & \\
\hline Schedule & See Appendix C & \\
\hline Daylighting Controls & ASHRAE 90.1 Requirements & \\
\hline
\end{tabular}




\begin{tabular}{|c|c|c|}
\hline Item & Descriptions & Data Source \\
\hline Occupancy Sensors & ASHRAE 90.1 Requirements & \\
\hline \multicolumn{3}{|l|}{ Plug load } \\
\hline Average power density $\left(\mathrm{W} / \mathrm{ft}^{2}\right)$ & See Appendix B & $\begin{array}{l}\text { User's Manual for } \\
\text { ASHRAE Standard 90.1- } \\
2004 \text { (Appendix G) }\end{array}$ \\
\hline Schedule & See Appendix C & \\
\hline \multicolumn{3}{|l|}{ Occupancy } \\
\hline Average people & See Appendix B & \\
\hline Schedule & See Appendix C & \\
\hline \multicolumn{3}{|l|}{ Misc. } \\
\hline \multicolumn{3}{|l|}{ Elevator } \\
\hline Peak Power & NA & \\
\hline Schedule & NA & \\
\hline \multicolumn{3}{|l|}{ Exterior Lighting } \\
\hline Peak Power & 7,322 watts & \multirow{2}{*}{ ASHRAE 90.1} \\
\hline Schedule & See Appendix C & \\
\hline
\end{tabular}

\section{References}

Briggs, R.S., R.G. Lucas, and Z.T. Taylor. 2003. Climate Classification for Building Energy Codes and Standards:

Part 2-Zone Definitions, Maps, and Comparisons. ASHRAE Transactions 109(2).

PNNL's CBECS Study. 2007. Analysis of Building Envelope Construction in 2003 CBECS Buildings. Dave Winiarski, Mark Halverson, and Wei Jiang. Pacific Northwest National Laboratory. March 2007.

PNNL's CBECS Study. 2006. Review of Pre- and Post-1980 Buildings in CBECS - HVAC Equipment. Dave Winiarski, Wei Jiang and Mark Halverson. Pacific Northwest National Laboratory. December 2006.

Gowri K, DW Winiarski, and RE Jarnagin. 2009. Infiltration modeling guidelines for commercial building energy analysis. PNNL-18898, Pacific Northwest National Laboratory, Richland, WA. http://www.pnl.gov/main/publications/external/technical_reports/PNNL-18898.pdf 


\section{A.4 Primary School Modeling Description}

\begin{tabular}{|c|c|c|c|c|}
\hline Item & \multicolumn{3}{|c|}{ Descriptions } & Data Source \\
\hline \multicolumn{5}{|l|}{ Program } \\
\hline \begin{tabular}{|l|l|} 
Vintage \\
\end{tabular} & \multicolumn{3}{|c|}{ NEW CONSTRUCTION } & \\
\hline $\begin{array}{l}\text { Location } \\
\text { (Representing } 8 \text { Climate Zones) }\end{array}$ & $\begin{array}{l}\text { Zone 1A: Miami (very hot, humid) } \\
\text { Zone 1B: Riyadh, Saudi Arabia } \\
\text { (very hot, dry) } \\
\text { Zone 2A: Houston (hot, humid) } \\
\text { Zone 2B: Phoenix (hot, dry) } \\
\text { Zone 3A: Memphis (warm, humid) } \\
\text { Zone 3B: El Paso (warm, dry) } \\
\text { Zone 3C: San Francisco (warm, } \\
\text { marine) }\end{array}$ & $\begin{array}{l}\text { Zone 4A: Baltimore (mild, humid) } \\
\text { Zone 4B: Albuquerque (mild, dry) } \\
\text { Zone 4C: Salem (mild, marine) } \\
\text { Zone 5A: Chicago (cold, humid) } \\
\text { Zone 5B: Boise (cold, dry) } \\
\text { Zone 5C: Vancouver, BC (cold, } \\
\text { marine) }\end{array}$ & $\begin{array}{l}\text { Zone 6A: Burlington (cold, humid) } \\
\text { Zone 6B: Helena (cold, dry) } \\
\text { Zone 7: Duluth (very cold) } \\
\text { Zone 8: Fairbanks (subarctic) }\end{array}$ & $\begin{array}{l}\text { Selection of representative } \\
\text { climates based on Briggs' } \\
\text { paper }\end{array}$ \\
\hline Available fuel types & & gas, electricity & & \\
\hline $\begin{array}{l}\text { Building Type (Principal Building } \\
\text { Function) }\end{array}$ & & EDUCATION & & \\
\hline Building Prototype & & Primary School & & \\
\hline \multicolumn{5}{|l|}{ Form } \\
\hline Total Floor Area (sq. feet) & & $\begin{array}{c}73,960 \\
(340 \mathrm{ft} \times 270 \mathrm{ft})\end{array}$ & & \\
\hline \multicolumn{5}{|l|}{ Building shape } \\
\hline Aspect Ratio & & 1.3 & & \\
\hline Number of Floors & & 1 & & \\
\hline
\end{tabular}




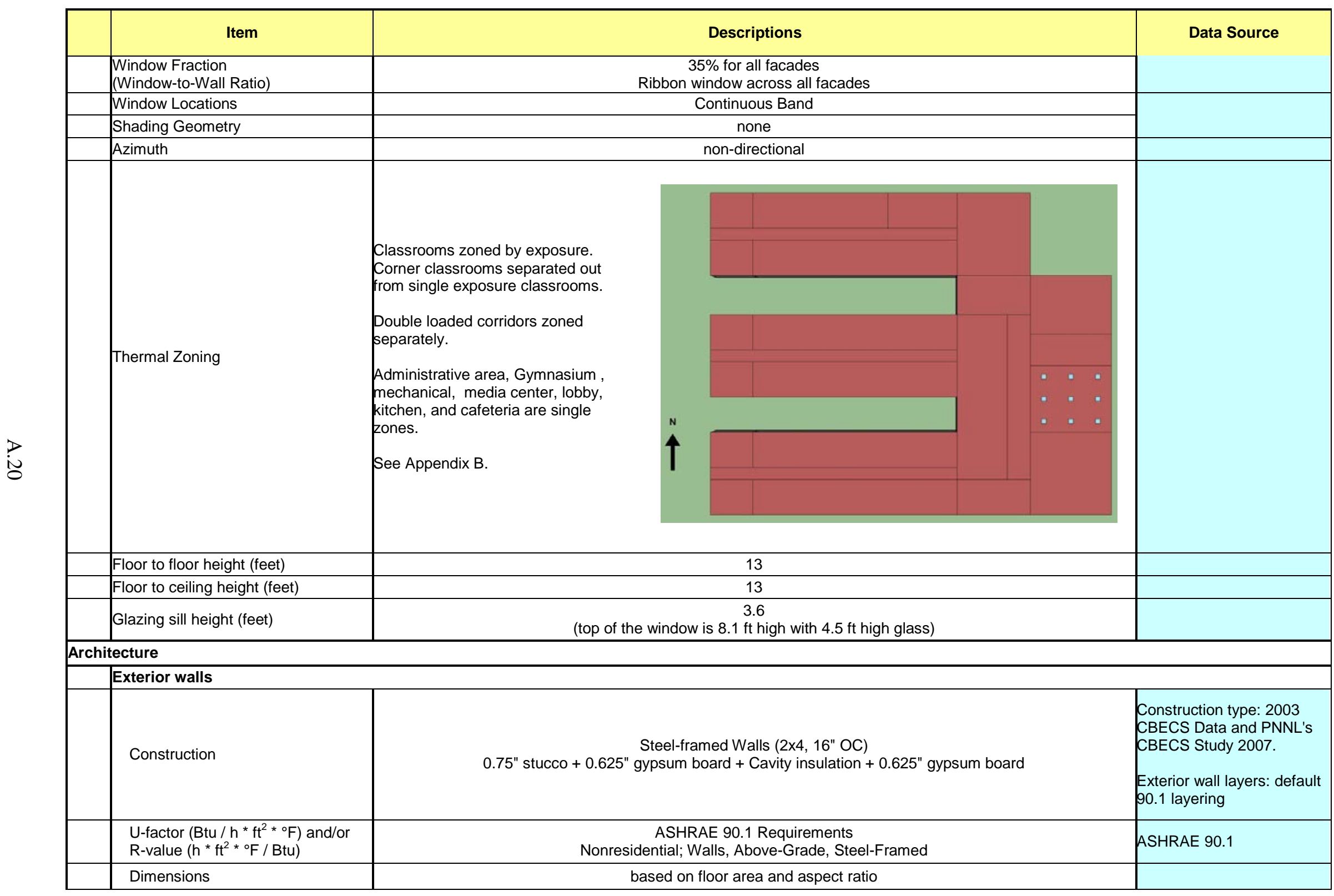




\begin{tabular}{|c|c|c|}
\hline Item & Descriptions & Data Source \\
\hline Tilts and orientations & vertical & \\
\hline \multicolumn{3}{|l|}{ Roof } \\
\hline Construction & $\begin{aligned} & \text { Built-up Roof } \\
\text { Roof membrane } & \text { Roof insulation + Metal decking }\end{aligned}$ & $\begin{array}{l}\text { Construction type: } 2003 \\
\text { CBECS Data and PNNL's } \\
\text { CBECS Study } 2007 . \\
\text { Roof layers: default } 90.1 \\
\text { layering }\end{array}$ \\
\hline $\begin{array}{l}\text { U-factor }\left(\mathrm{Btu} / \mathrm{h} * \mathrm{ft}^{2} *{ }^{\circ} \mathrm{F}\right) \text { and/or } \\
\mathrm{R} \text {-value }\left(\mathrm{h} * \mathrm{ft}^{2} *{ }^{\circ} \mathrm{F} / \mathrm{Btu}\right)\end{array}$ & $\begin{array}{l}\text { ASHRAE 90.1 Requirements } \\
\text { Nonresidential; Roofs, Insulation entirely above deck }\end{array}$ & ASHRAE 90.1 \\
\hline Area (ft2) & 73,960 & \\
\hline Tilts and orientations & horizontal & \\
\hline \multicolumn{3}{|l|}{ Window } \\
\hline Dimensions & based on window fraction, location, glazing sill height, floor area and aspect ratio & \\
\hline Glass-Type and frame & Hypothetical window with no frame and meeting ASHRAE 90.1 Requirements & \\
\hline $\begin{array}{l}\left.\text { U-factor (Btu } / \mathrm{h} * \mathrm{ft}^{2}{ }^{\circ} \mathrm{F}\right) \\
\text { SHGC (all) }\end{array}$ & $\begin{array}{c}\text { ASHRAE 90.1 Requirements } \\
\text { Nonresidential; Vertical Glazing, 30.1-40\% }\end{array}$ & ASHRAE 90.1 \\
\hline $\begin{array}{l}\text { SHGC (all) } \\
\text { Visible transmittance }\end{array}$ & Hypothetical window with no frame and meeting ASHRAE 90.1 Requirements & \\
\hline Operable area & ( & $\begin{array}{l}\text { PNNL 's Glazing Market } \\
\text { Data for ASHRAE } \\
\text { spreadsheet }\end{array}$ \\
\hline \multicolumn{3}{|l|}{ Skylight } \\
\hline Dimensions & $\begin{array}{c}\text { Gymnasium/Multipurpose Room } \\
(4 \mathrm{ft} \times 4 \mathrm{ft}) \times 9 \text { skylights }=144 \mathrm{ft}^{2} \text { total Skylight Area } \\
3.75 \% \text { of gym roof area }\end{array}$ & AEDG K-12 Guide \\
\hline Glass-Type and frame & Hypothetical glass and frame meeting ASHRAE 90.1 Requirements below & \\
\hline U-factor $\left(\mathrm{Btu} / \mathrm{h} * \mathrm{ft}^{2} *{ }^{\circ} \mathrm{F}\right)$ & \multirow{3}{*}{$\begin{array}{l}\text { ASHRAE 90.1 Requirements } \\
\text { Nonresidential; Skylight with curb, Glass, 2.1-5\% }\end{array}$} & \multirow{3}{*}{ ASHRAE 90.1} \\
\hline SHGC & & \\
\hline Visible transmittance & & \\
\hline \multicolumn{3}{|l|}{ Foundation } \\
\hline Foundation Type & Slab-on-grade floors (unheated) & \\
\hline Construction & 6" concrete slab poured directly on to the earth + carpet & \\
\hline $\begin{array}{l}\text { Thermal properties for ground } \\
\text { level floor: } \\
\text { F-factor }\left(\mathrm{Btu} / \mathrm{h} * \mathrm{ft}^{2} *{ }^{\circ} \mathrm{F}\right) \\
\text { and/or } \\
\mathrm{R} \text {-value }\left(\mathrm{h} * \mathrm{ft}^{2} *{ }^{\circ} \mathrm{F} / \mathrm{Btu}\right) \\
\end{array}$ & $\begin{array}{l}\text { ASHRAE 90.1 Requirements } \\
\text { Nonresidential; Slab-on-Grade Floors, unheated }\end{array}$ & ASHRAE 90.1 \\
\hline $\begin{array}{l}\text { Thermal properties for } \\
\text { basement walls: }\end{array}$ & NA & \\
\hline Dimensions & based on floor area and aspect ratio & \\
\hline
\end{tabular}




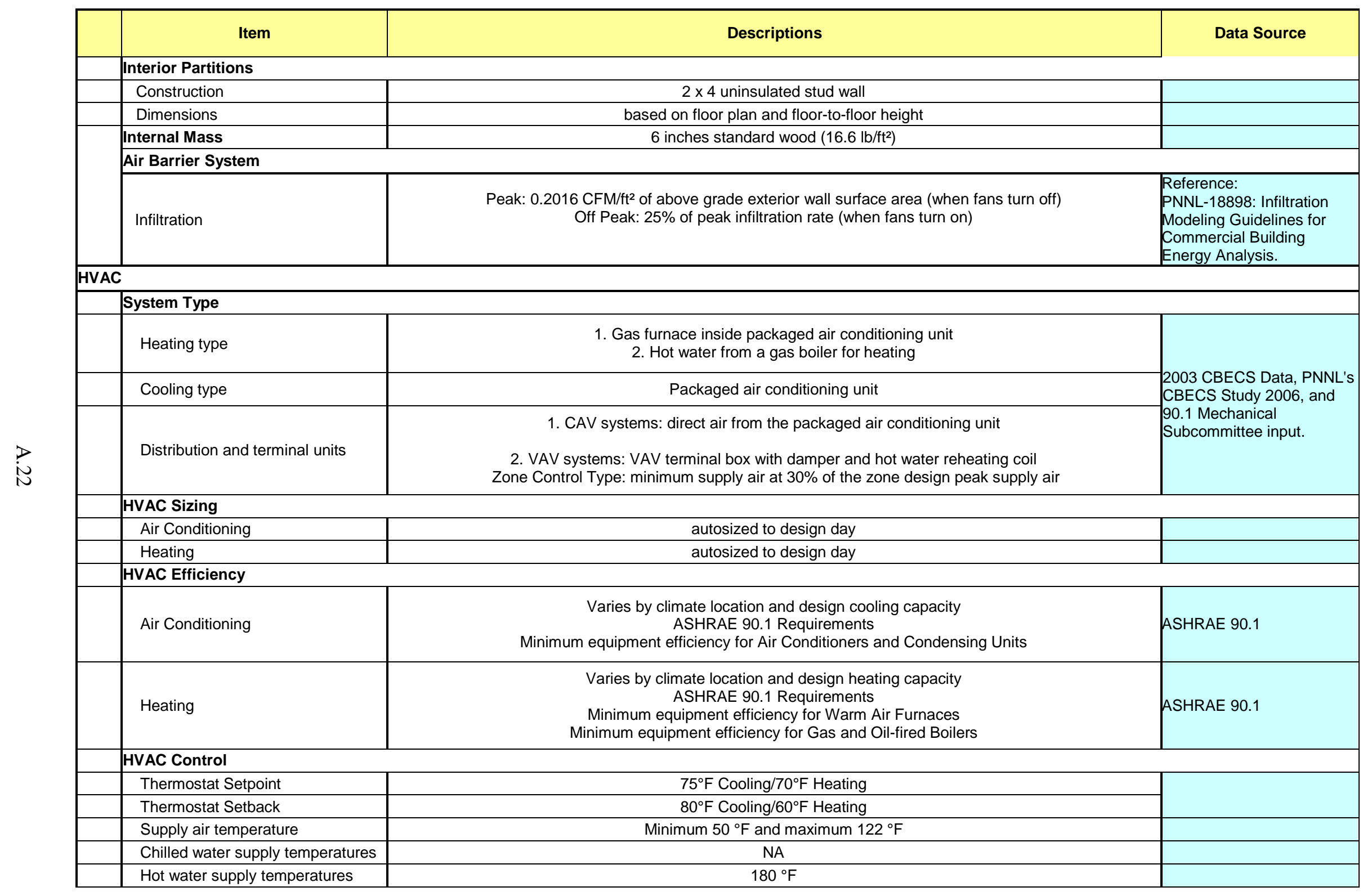




\begin{tabular}{|c|c|c|}
\hline Item & Descriptions & Data Source \\
\hline Economizers & $\begin{array}{l}\text { Varies by climate location and cooling capacity } \\
\text { Control type: differential dry bulb }\end{array}$ & ASHRAE 90.1 \\
\hline Outdoor Air Ventilation & ASHRAE Ventilation Standard 62.1 & $\begin{array}{l}\text { ASHRAE Ventilation } \\
\text { Standard } 62.1\end{array}$ \\
\hline Demand Control Ventilation & ASHRAE 90.1 Requirements & ASHRAE 90.1 \\
\hline Energy Recovery & ASHRAE 90.1 Requirements & ASHRAE 90.1 \\
\hline \multicolumn{3}{|l|}{ Supply Fan } \\
\hline Fan schedules & See Appendix C & \\
\hline Supply Fan Mechanical Efficiency & Varies depending on the fan motor size and type of fan & \multirow{2}{*}{$\begin{array}{l}\text { ASHRAE } 90.1 \text { requirements } \\
\text { for motor efficiency and fan } \\
\text { power limitation }\end{array}$} \\
\hline Supply Fan Pressure Drop & Various depending on the fan supply air CFM & \\
\hline \multicolumn{3}{|l|}{ Pump } \\
\hline Pump Type & Variable speed & \\
\hline Rated Pump Head & $60 \mathrm{ft}$ & \\
\hline Pump Power & autosized & \\
\hline \multicolumn{3}{|l|}{ Cooling Tower } \\
\hline Cooling Tower Type & NA & \\
\hline Cooling Tower Power & NA & \\
\hline \multicolumn{3}{|l|}{ Service Water Heating } \\
\hline SWH type & Storage Tank & \\
\hline Fuel type & Natural Gas & \\
\hline Thermal efficiency (\%) & $\begin{array}{l}\text { ASHRAE } 90.1 \text { Requirements } \\
\text { Water Heating Equipment, Gas storage water heaters, }>75,000 \text { Btu/h input }\end{array}$ & ASHRAE 90.1 \\
\hline Tank Volume (gal) & 264 & \\
\hline Water temperature setpoint & $120 \mathrm{~F}$ & \\
\hline Water consumption (peak gpm) & See Appendix C & \\
\hline \multicolumn{3}{|l|}{ Internal Loads \& Schedules } \\
\hline \multicolumn{3}{|l|}{ Lighting } \\
\hline Lighting power density $\left(\mathrm{W} / \mathrm{ft}^{2}\right)$ & $\begin{array}{c}\text { ASHRAE 90.1 } \\
\begin{array}{c}\text { Lighting Power Densities Using the Space-By-Space Method } \\
\text { See Appendix B }\end{array}\end{array}$ & ASHRAE 90.1 \\
\hline Schedule & See Appendix C & \\
\hline Daylighting Controls & ASHRAE 90.1 Requirements & \\
\hline Occupancy Sensors & ASHRAE 90.1 Requirements & \\
\hline \multicolumn{3}{|l|}{ Plug load } \\
\hline Average power density $\left(\mathrm{W} / \mathrm{ft}^{2}\right)$ & See Appendix B & $\begin{array}{l}\text { User's Manual for ASHRAE } \\
\text { Standard 90.1-2004 } \\
\text { (Appendix G) }\end{array}$ \\
\hline Schedule & See Appendix C & \\
\hline
\end{tabular}




\begin{tabular}{|c|c|c|c|}
\hline & Item & Descriptions & Data Source \\
\hline & \multicolumn{3}{|l|}{ Occupancy } \\
\hline & Average people & See Appendix B & \\
\hline & Schedule & See Appendix C & \\
\hline \multicolumn{4}{|l|}{ Misc. } \\
\hline \multicolumn{4}{|c|}{ Elevator } \\
\hline & Peak Power & NA & \\
\hline & Schedule & NA & \\
\hline \multicolumn{4}{|c|}{ Exterior Lighting } \\
\hline & Peak Power (W) & $\begin{array}{c}\text { ASHRAE 90.1 } \\
\text { Lighting Power Densities For Building Exteriors }\end{array}$ & ASHRAE 90.1 \\
\hline & Schedule & See Appendix C & \\
\hline
\end{tabular}

References

Briggs, R.S., R.G. Lucas, and Z.T. Taylor. 2003. Climate Classification for Building Energy Codes and Standards:

Part 2-Zone Definitions, Maps, and Comparisons. ASHRAE Transactions 109(2).

PNNL's CBECS Study. 2007. Analysis of Building Envelope Construction in 2003 CBECS Buildings. Dave Winiarski, Mark Halverson, and Wei Jiang. Pacific Northwest National Laboratory. March 2007.

PNNL'S CBECS Study. 2006. Review of Pre- and Post-1980 Buildings in CBECS - HVAC Equipment. Dave Winiarski, Wei Jiang and Mark Halverson. Pacific Northwest National Laboratory. December 2006.

"Study of the U.S. Market For Windows, Doors, and Skylights", American Architectural Manufacturers Association, Window \& Door Manufacturers

Association, 2006 


\section{A.5 Small Hotel Modeling Description}

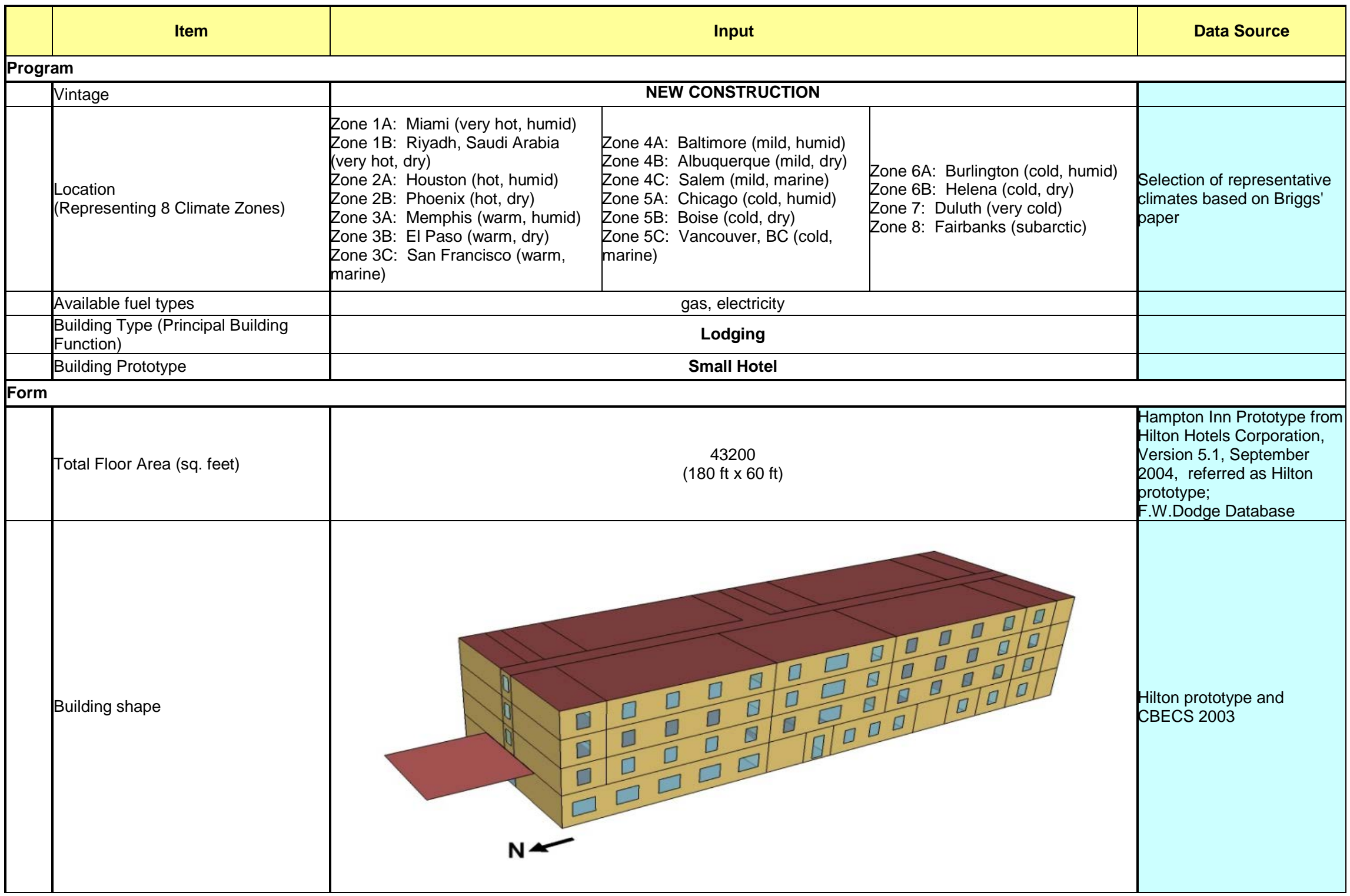




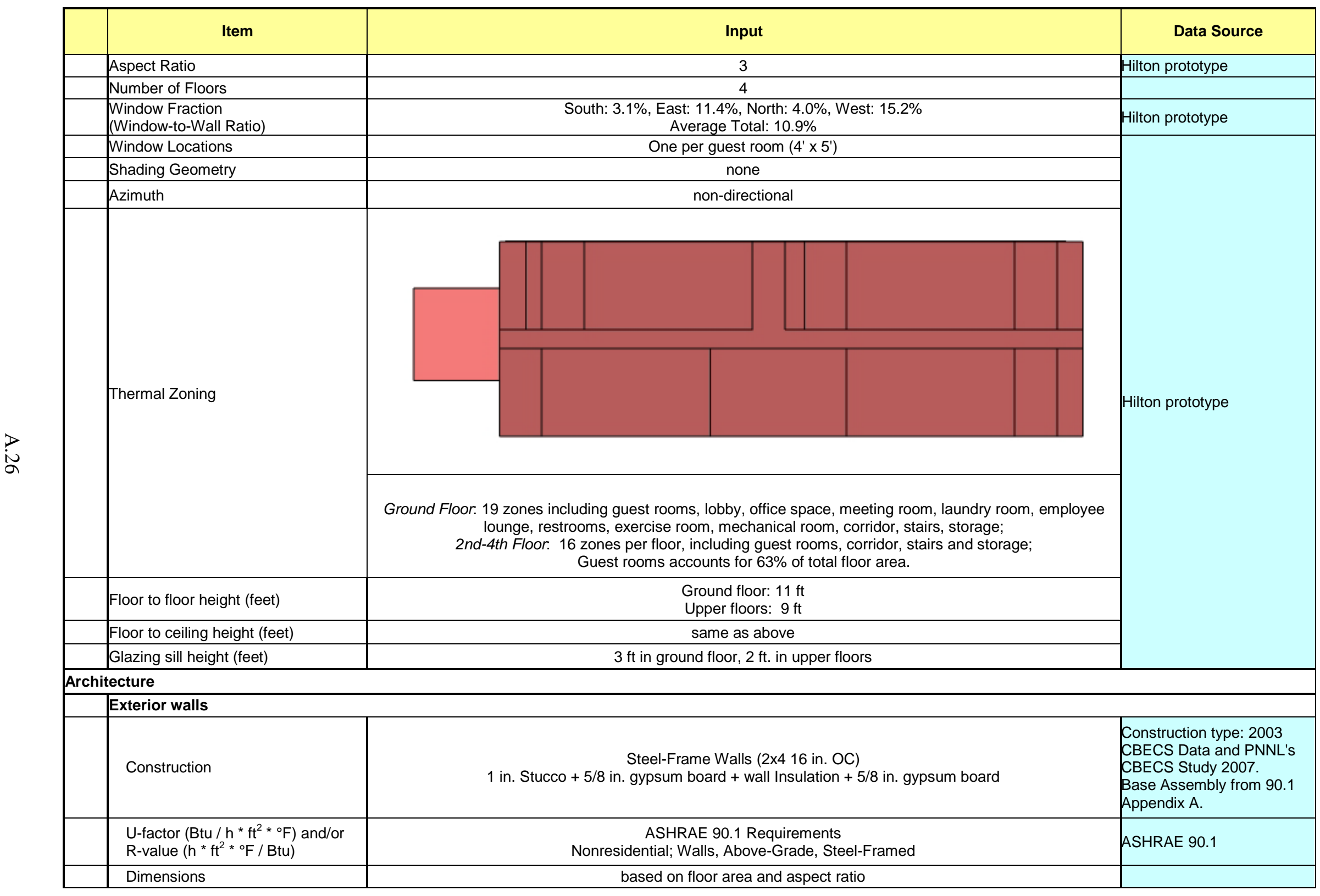




\begin{tabular}{|c|c|c|}
\hline Item & Input & Data Source \\
\hline Tilts and orientations & vertical & \\
\hline \multicolumn{3}{|l|}{ Roof } \\
\hline Construction & $\begin{array}{l}\text { Built-up Roof: } \\
\text { Roof membrane + Roof insulation + metal decking }\end{array}$ & $\begin{array}{l}\text { AEDG Highway Lodging } \\
\text { Committee } \\
\text { Recommendation }\end{array}$ \\
\hline $\begin{array}{l}\text { U-factor }\left(\mathrm{Btu} / \mathrm{h} * \mathrm{ft}^{2} *{ }^{\circ} \mathrm{F}\right) \text { and/or } \\
\text { R-value }\left(\mathrm{h} * \mathrm{ft}^{2} *{ }^{\circ} \mathrm{F} / \mathrm{Btu}\right)\end{array}$ & $\begin{array}{c}\text { ASHRAE 90.1 Requirements } \\
\text { Nonresidential; Roofs, Insulation entirely above deck }\end{array}$ & ASHRAE 90.1 \\
\hline Dimensions & based on floor area and aspect ratio & \\
\hline Tilts and orientations & horizontal & \\
\hline \multicolumn{3}{|l|}{ Window } \\
\hline Dimensions & based on window fraction, location, glazing sill height, floor area and aspect ratio & \\
\hline Glass-Type and frame & Hypothetical window with the exact U-factor and SHGC shown below & \\
\hline U-factor $\left(\mathrm{Btu} / \mathrm{h} * \mathrm{ft}^{2}{ }^{\circ} \mathrm{F}\right)$ & ASHRAE 90.1 Requirements & ASHRAE 901 \\
\hline SHGC (all) & Nonresidential for ground floor and residential for upper floors; Vertical Glazing, 10.1\%-20.0\% & 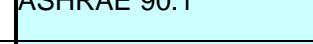 \\
\hline Visible transmittance & Hypothetical window with the exact U-factor and SHGC shown above & \\
\hline Operable area & $0.00 \%$ & \\
\hline \multicolumn{3}{|l|}{ Skylight } \\
\hline Dimensions & Not Modeled & \\
\hline Glass-Type and frame & \multirow{4}{*}{ NA } & \\
\hline U-factor $\left(\mathrm{Btu} / \mathrm{h} * \mathrm{ft}^{2} *{ }^{\circ} \mathrm{F}\right)$ & & \\
\hline SHGC (all) & & \\
\hline Visible transmittance & & \\
\hline \multicolumn{3}{|l|}{ Foundation } \\
\hline Foundation Type & Slab-on-grade floors (unheated) & \\
\hline Construction & 6" concrete slab poured directly on to the earth & \\
\hline $\begin{array}{l}\text { Thermal properties for slab-on- } \\
\text { grade floor } \\
\text { F-factor }\left(\mathrm{Btu} / \mathrm{h} * \mathrm{ft} 2 *{ }^{\circ} \mathrm{F}\right) \\
\text { and/or } \\
\mathrm{R} \text {-value }\left(\mathrm{h} * \mathrm{ft} 2 *{ }^{\circ} \mathrm{F} / \mathrm{Btu}\right)\end{array}$ & ASHRAE 90.1 Requirements & ASHRAE 90.1 \\
\hline $\begin{array}{l}\text { Thermal properties for } \\
\text { basement walls }\end{array}$ & NA & \\
\hline Dimensions & based on floor area and aspect ratio & \\
\hline \multicolumn{3}{|l|}{ Interior Partitions } \\
\hline Construction & $2 \times 4$ uninsulated stud wall & \\
\hline Dimensions & based on floor plan and floor-to-floor height & \\
\hline Internal Mass & 6 inches standard wood $\left(16.6 \mathrm{lb} / \mathrm{ft}^{2}\right)$ & \\
\hline \multicolumn{3}{|l|}{ Air Barrier System } \\
\hline
\end{tabular}




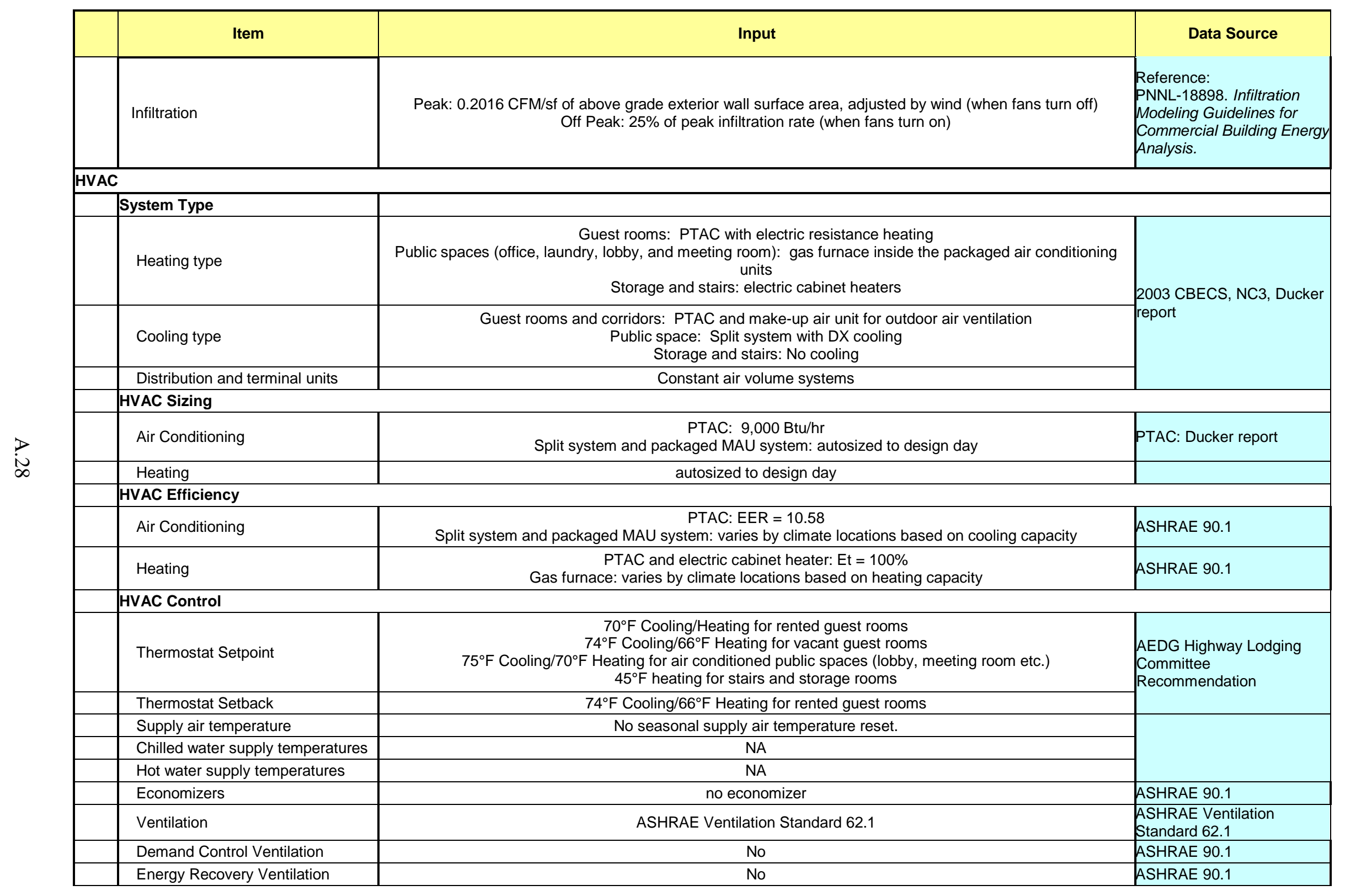




\begin{tabular}{|c|c|c|}
\hline Item & Input & Data Source \\
\hline \multicolumn{3}{|l|}{ Supply Fan } \\
\hline Fan schedules & See Appendix C & \\
\hline $\begin{array}{l}\text { Supply Fan Mechanical } \\
\text { Efficiency (\%) }\end{array}$ & Varies by fan motor size & $\begin{array}{l}\text { AEDG-SR Technical } \\
\text { Support Document (Liu } \\
\text { 2006) }\end{array}$ \\
\hline Supply Fan Pressure Drop & $\begin{array}{c}\text { PTAC: } 1.33 \text { in. w.c. } \\
\text { Cabinet Heater: } 0.2 \text { in w.c. } \\
\text { Split DX units and MAU: } 90.1 \text { fan power limitation (depends on design flow rate) }\end{array}$ & $\begin{array}{l}\text { PTAC Manufacture's } \\
\text { Catalogs } \\
\text { Split System: Wassmer and } \\
\text { Brandemuehl, 2006, }\end{array}$ \\
\hline \multicolumn{3}{|l|}{ Pump } \\
\hline Pump Type & Constant speed (recirculating pump for DHW) & \multirow{3}{*}{$\begin{array}{l}\text { AEDG Highway Lodging } \\
\text { Committee } \\
\text { Recommendation }\end{array}$} \\
\hline Rated Pump Head & $20 \mathrm{ft}$ & \\
\hline Pump Power & autosized & \\
\hline \multicolumn{3}{|l|}{ Cooling Tower } \\
\hline Cooling Tower Type & NA & \\
\hline Cooling Tower Power & NA & \\
\hline \multicolumn{3}{|l|}{ Service Water Heating } \\
\hline SWH type & Two Storage Tanks: one for laundry and the other for guest rooms & \\
\hline Fuel type & Natural Gas & \\
\hline Thermal efficiency (\%) & $80 \%$ & $\begin{array}{l}\text { ASHRAE 90.1-2004, Table } \\
\text { 7.8, Gas storage water } \\
\text { heaters, >=75,000 Btu/h }\end{array}$ \\
\hline Tank Volume (gal) & 200 gal for guest rooms and 100 gal for laundry & $\begin{array}{l}\text { ASHRAE Handbook } \\
\text { Application 2007, Ch. } 49 \\
\text { Calculation is documented } \\
\text { at PNNL's TSD for 30\% } \\
\text { aEDG Highway Lodging } \\
\text { (Jiang et al 2008) }\end{array}$ \\
\hline Water temperature setpoint & $120 \mathrm{~F}$ for guest rooms and $140 \mathrm{~F}$ for laundry & \\
\hline Water consumption & See Appendix C & $\begin{array}{l}\text { Guest room: ASHRAE } \\
\text { Handbook of Applications } \\
\text { 2007, Chapter } 49 \text {, Table } 7 \\
\text { Laundry: AEDG Highway } \\
\text { Lodging Committee } \\
\text { Recommendation }\end{array}$ \\
\hline \multicolumn{3}{|l|}{ Internal Loads \& Schedules } \\
\hline \multicolumn{3}{|l|}{\begin{tabular}{l|l} 
Lighting \\
\end{tabular}} \\
\hline Average power density $\left(\mathrm{W} / \mathrm{ft}^{2}\right)$ & $\begin{array}{c}\text { ASHRAE } 90.1 \\
\text { Lighting Power Densities Using the Building Space-by-Space Method }\end{array}$ & ASHRAE 90.1 \\
\hline Schedule & See Appendix C & \\
\hline Daylighting Controls & No & \\
\hline Occupancy Sensors & No & \\
\hline
\end{tabular}




\begin{tabular}{|c|c|c|}
\hline Item & Input & Data Source \\
\hline \multicolumn{3}{|l|}{ Plug load } \\
\hline Average power density $\left(\mathrm{W} / \mathrm{ft}^{2}\right)$ & See Appendix B & $\begin{array}{l}\text { AEDG Highway Lodging } \\
\text { Committee } \\
\text { Recommendation }\end{array}$ \\
\hline Schedule & See Appendix C & \\
\hline \multicolumn{3}{|l|}{ Occupancy } \\
\hline Average people & See Appendix B & $\begin{array}{l}\text { Guest Room: AEDG } \\
\text { Highway Lodging } \\
\text { Committee } \\
\text { Recommendation } \\
\text { All other spaces: ASHRAE } \\
\text { 62.1-1999 }\end{array}$ \\
\hline Schedule & See Appendix C & \\
\hline \multicolumn{3}{|l|}{ Misc. } \\
\hline \begin{tabular}{|l|l|} 
Elevator \\
\end{tabular} & & \\
\hline Quantity & 2 & \multirow{4}{*}{$\begin{array}{l}\text { DOE Commercial Reference } \\
\text { Building TSD (Deru et al. } \\
\text { 2011) and models } \\
\text { (V1.3_5.0). }\end{array}$} \\
\hline Motor type & hydraulic & \\
\hline Peak Motor Power (W/elevator) & 16055 & \\
\hline Heat Gain to Building & Interior & \\
\hline $\begin{array}{l}\text { Peak Fan/lights Power } \\
\text { (W/elevator) }\end{array}$ & 161.9 & $\begin{array}{l}\text { 90.1 Mechanical } \\
\text { Subcommittee, Elevator } \\
\text { Working Group }\end{array}$ \\
\hline Exterior Lighting & See Appendix C & $\begin{array}{l}\text { DOE Commercial Reference } \\
\text { Building TSD (Deru et al. } \\
\text { 2011) and models } \\
\text { (V1.3_5.0) and Appendix DF } \\
2007\end{array}$ \\
\hline Peak Power, kW & 13.03 & \multirow{2}{*}{$\begin{array}{l}\text { Derived based on ASHRAE } \\
\text { 90.1-2004 and inputs from } \\
\text { 90.1 Lighting Subcommittee }\end{array}$} \\
\hline Schedule & Astronomical Clock & \\
\hline
\end{tabular}

\section{References}

Briggs, R.S., R.G. Lucas, and Z.T. Taylor. 2003. Climate Classification for Building Energy Codes and Standards:

Part 2-Zone Definitions, Maps, and Comparisons. ASHRAE Transactions 109(2).

McGraw-Hill Companies, Inc. (2001). Time-Saver Standards for Building Types. New York, NY.

LBNL (1991). Huang, Joe, Akbari, H., Rainer, L. and Ritschard, R. 481 Prototypical Commercial Buildings for 20 Urban Market Areas, prepared for the Gas Research Institute, Chicago IL, also LBL-29798, Berkeley CA.

PNNL's CBECS Study. 2007. Analysis of Building Envelope Construction in 2003 CBECS Buildings. Dave Winiarski, Mark Halverson, and Wei Jiang. Pacific Northwest National Laboratory. March 2007. 


\section{References (continued)}

PNNL's CBECS Study. 2006. Review of Pre- and Post-1980 Buildings in CBECS - HVAC Equipment. Dave Winiarski, Wei Jiang and Mark Halverson. Pacific Northwest National Laboratory. December 2006.

Ducker International Standard. 2001. 2000 U.S. Market For Residential and Specialty Air Conditioning: PTAC.

Sachs, H., 2005. Opportunities for Elevator Energy Efficiency Improvements, ACEEE.

Wassmer and Brandemuehl, 2006, Effect of Data Availability on Modeling of Residential Air Conditioners and Heat Pumps for Energy Calculations 


\section{A.6 Mid-Rise Apartment Modeling Description}

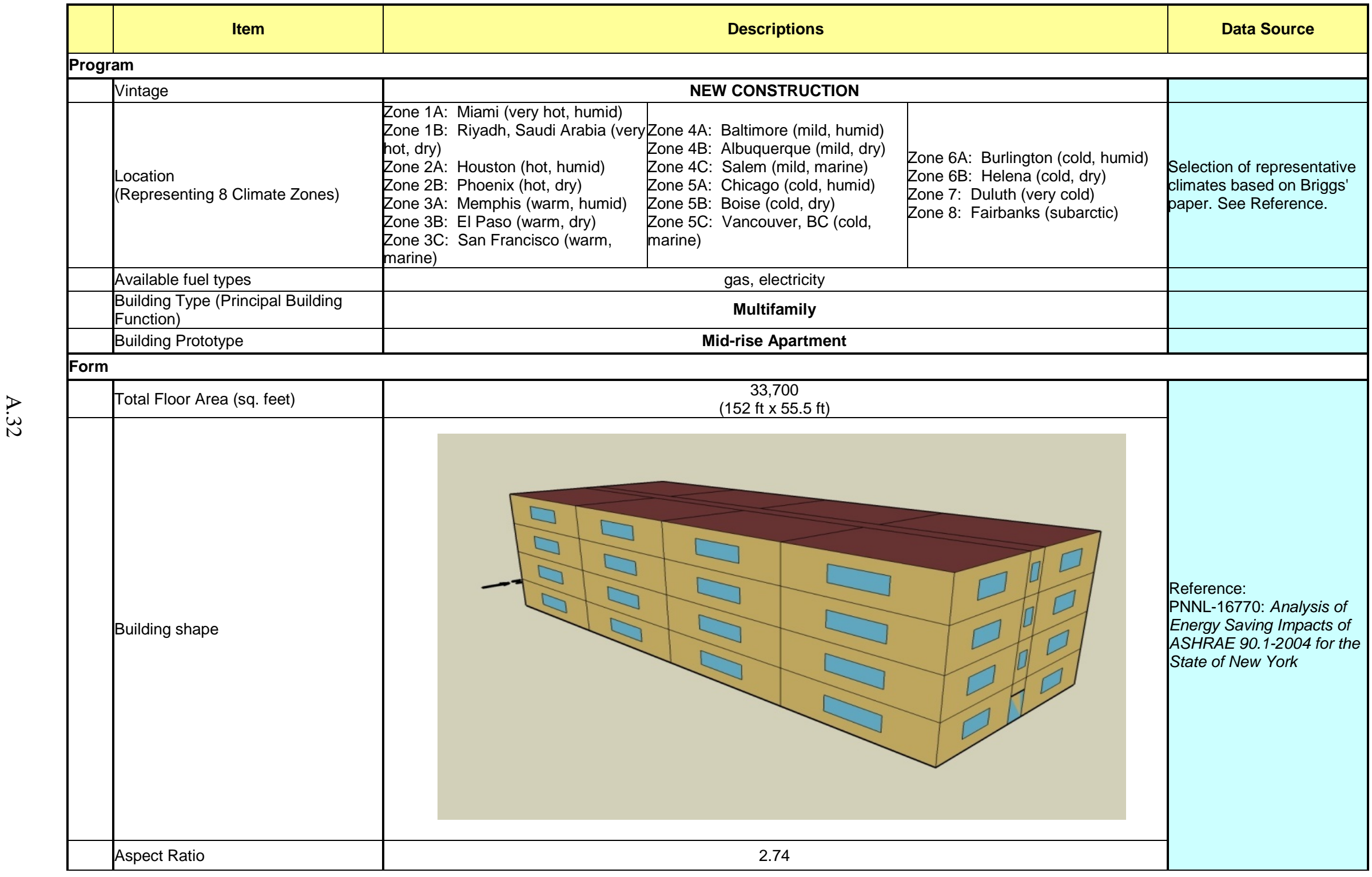




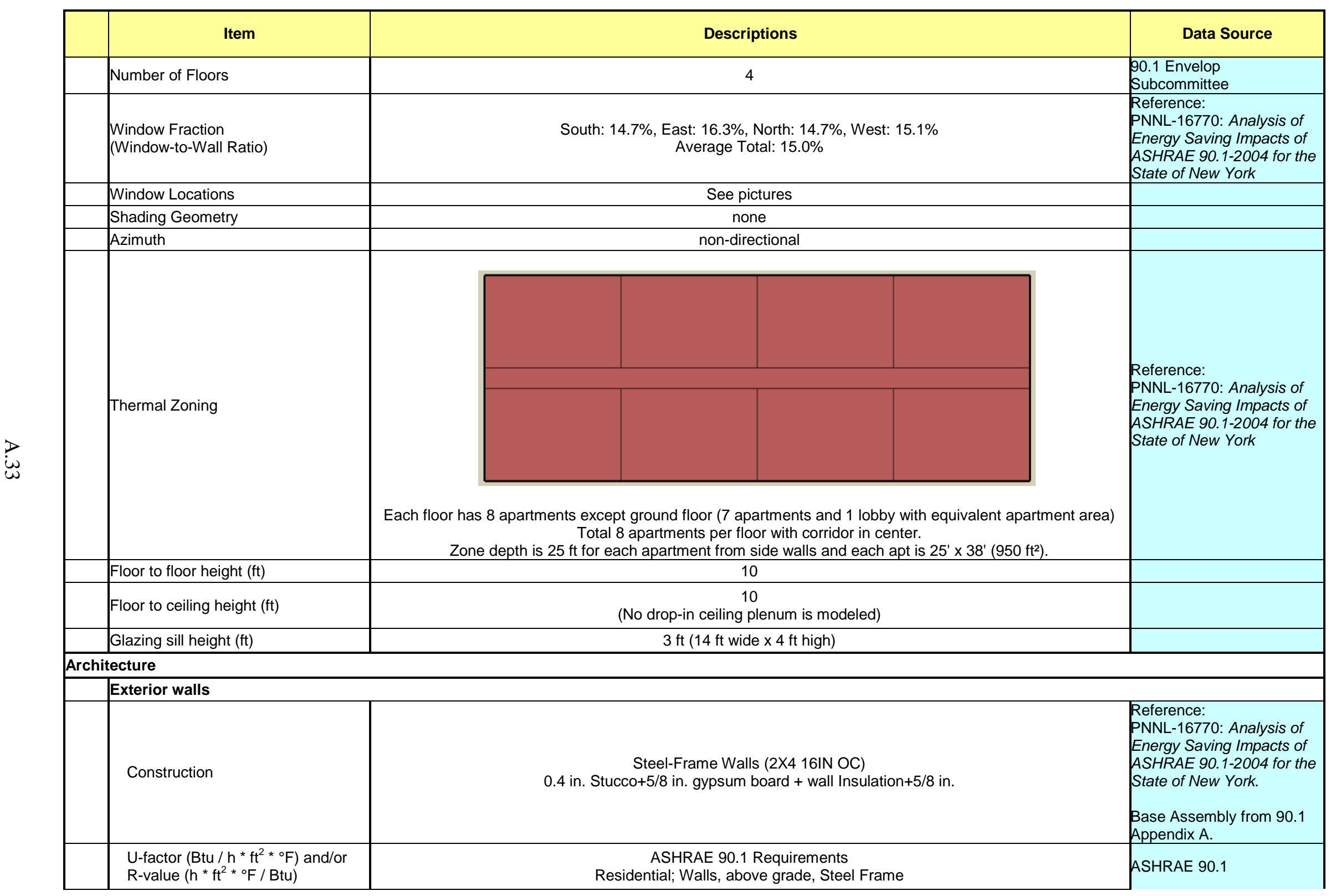




\begin{tabular}{|c|c|c|}
\hline Item & Descriptions & Data Source \\
\hline Dimensions & based on floor area and aspect ratio & \\
\hline Tilts and orientations & vertical & \\
\hline \multicolumn{3}{|l|}{ Roof } \\
\hline Construction & $\begin{array}{l}\text { Built-up Roof: } \\
\text { Roof membrane+Roof insulation+metal decking }\end{array}$ & $\begin{array}{l}\text { Reference: } \\
\text { PNNL-16770: Analysis of } \\
\text { Energy Saving Impacts of } \\
\text { ASHRAE 90.1-2004 for the } \\
\text { State of New York } \\
\text { Base Assembly from } 90.1 \\
\text { Appendix A. }\end{array}$ \\
\hline $\begin{array}{l}\text { U-factor }\left(\mathrm{Btu} / \mathrm{h} * \mathrm{ft}^{2} *{ }^{\circ} \mathrm{F}\right) \text { and/or } \\
\text { R-value }\left(\mathrm{h} * \mathrm{ft}^{2} *{ }^{\circ} \mathrm{F} / \mathrm{Btu}\right)\end{array}$ & $\begin{array}{l}\text { ASHRAE 90.1 Requirements } \\
\text { Residential; Roofs, Insulation entirely above deck }\end{array}$ & ASHRAE 90.1 \\
\hline Dimensions & based on floor area and aspect ratio & \\
\hline Tilts and orientations & horizontal & \\
\hline \multicolumn{3}{|l|}{ Window } \\
\hline Dimensions & based on window fraction, location, glazing sill height, floor area and aspect ratio & \\
\hline Glass-Type and frame & Hypothetical window with the exact U-factor and SHGC shown below & \\
\hline U-factor $\left(\mathrm{Btu} / \mathrm{h} * \mathrm{ft}^{2}{ }^{\circ} \mathrm{F}\right)$ & ASHRAE 90.1 Requirements & 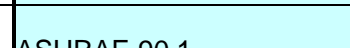 \\
\hline SHGC (all) & Residential; Vertical Glazing, 10.1-20\% & ASHRAE 90.1 \\
\hline Visible transmittance & Hypothetical window with the exact U-factor and SHGC shown above & \\
\hline Operable area & $100 \%$ & \\
\hline \multicolumn{3}{|l|}{ Skylight } \\
\hline Dimensions & Not Modeled & \\
\hline Glass-Type and frame & \multirow{4}{*}{ NA } & \\
\hline U-factor $\left(\mathrm{Btu} / \mathrm{h} * \mathrm{ft}^{2}{ }^{\circ} \mathrm{F}\right)$ & & \\
\hline SHGC (all) & & \\
\hline Visible transmittance & & \\
\hline \multicolumn{3}{|l|}{ Foundation } \\
\hline Foundation Type & Slab-on-grade floors (unheated) & \\
\hline Construction & $8 "$ concrete slab poured directly on to the earth & \\
\hline $\begin{array}{l}\text { Slab-on-grade floor insulation level } \\
\text { (F-factor) }\end{array}$ & ASHRAE 90.1 Requirements & ASHRAE 90.1 \\
\hline Dimensions & based on floor area and aspect ratio & \\
\hline \multicolumn{3}{|l|}{ Interior Partitions } \\
\hline Construction & $2 \times 4$ uninsulated stud wall & \\
\hline
\end{tabular}




\begin{tabular}{|c|c|c|}
\hline Item & Descriptions & Data Source \\
\hline Dimensions & based on floor plan and floor-to-floor height & \\
\hline Internal Mass & $8 \mathrm{lbs} / \mathrm{ft} 2$ of floor area & $\begin{array}{l}\text { Reference: } \\
\text { Building America Research } \\
\text { Benchmark }\end{array}$ \\
\hline \multicolumn{3}{|l|}{ Air Barrier System } \\
\hline Infiltration $(\mathrm{ACH})$ & $0.2016 \mathrm{CFM} / \mathrm{ft}^{2}$ of gross exterior wall area at all times (at $10 \mathrm{mph}$ wind speed) & $\begin{array}{l}\text { Reference: } \\
\text { PNNL-18898. Infiltration } \\
\text { Modeling Guidelines for } \\
\text { Commercial Building } \\
\text { Energy Analysis. }\end{array}$ \\
\hline \multicolumn{3}{|l|}{ HVAC } \\
\hline \begin{tabular}{|l|l|} 
System Type \\
\end{tabular} & & \\
\hline Heating type & Gas Furnace & \multirow{3}{*}{$\begin{array}{l}90.1 \text { Mechanical } \\
\text { Subcommittee }\end{array}$} \\
\hline Cooling type & Split system DX (1 per apt) & \\
\hline Distribution and terminal units & Constant volume & \\
\hline \multicolumn{3}{|l|}{ HVAC Sizing } \\
\hline Air Conditioning & autosized to design day & \\
\hline Heating & autosized to design day & \\
\hline \multicolumn{3}{|l|}{ HVAC Efficiency } \\
\hline Air Conditioning & $\begin{array}{l}\text { ASHRAE } 90.1 \text { Requirements } \\
\text { Minimum Equipment Efficiency for Air Conditioners and Condensing Units }\end{array}$ & ASHRAE 90.1 \\
\hline Heating & $\begin{array}{c}\text { ASHRAE 90.1 Requirements } \\
\text { Minimum Equipment Efficiency for Warm Air Furnaces }\end{array}$ & ASHRAE 90.1 \\
\hline \multicolumn{3}{|l|}{ HVAC Control } \\
\hline Thermostat Setpoint & $75^{\circ} \mathrm{F}$ Cooling $/ 70^{\circ} \mathrm{F}$ Heating & \\
\hline Thermostat Setback & No setback for apartments & \\
\hline Supply air temperature & Maximum 110F, Minimum 52F & \\
\hline Economizers & ASHRAE 90.1 Requirements & ASHRAE 90.1 \\
\hline Ventilation & ASHRAE Ventilation Standard 62.1 & $\begin{array}{l}\text { ASHRAE Ventilation } \\
\text { Standard } 62.1\end{array}$ \\
\hline Demand Control Ventilation & ASHRAE 90.1 Requirements & ASHRAE 90.1 \\
\hline Energy Recovery & ASHRAE 90.1 Requirements & ASHRAE 90.1 \\
\hline \multicolumn{3}{|l|}{ Supply Fan } \\
\hline Fan schedules & See Appendix C & \\
\hline Supply Fan Total Efficiency (\%) & Depending on the fan motor size & \multirow{2}{*}{$\begin{array}{l}\text { ASHRAE } 90.1 \text { requirements } \\
\text { for motor efficiency and fan } \\
\text { power limitation }\end{array}$} \\
\hline Supply Fan Pressure Drop & Depending on the fan supply air CFM & \\
\hline \multicolumn{3}{|l|}{ Service Water Heating } \\
\hline SWH type & Individual Residential Water Heater with Storage Tank & \\
\hline
\end{tabular}




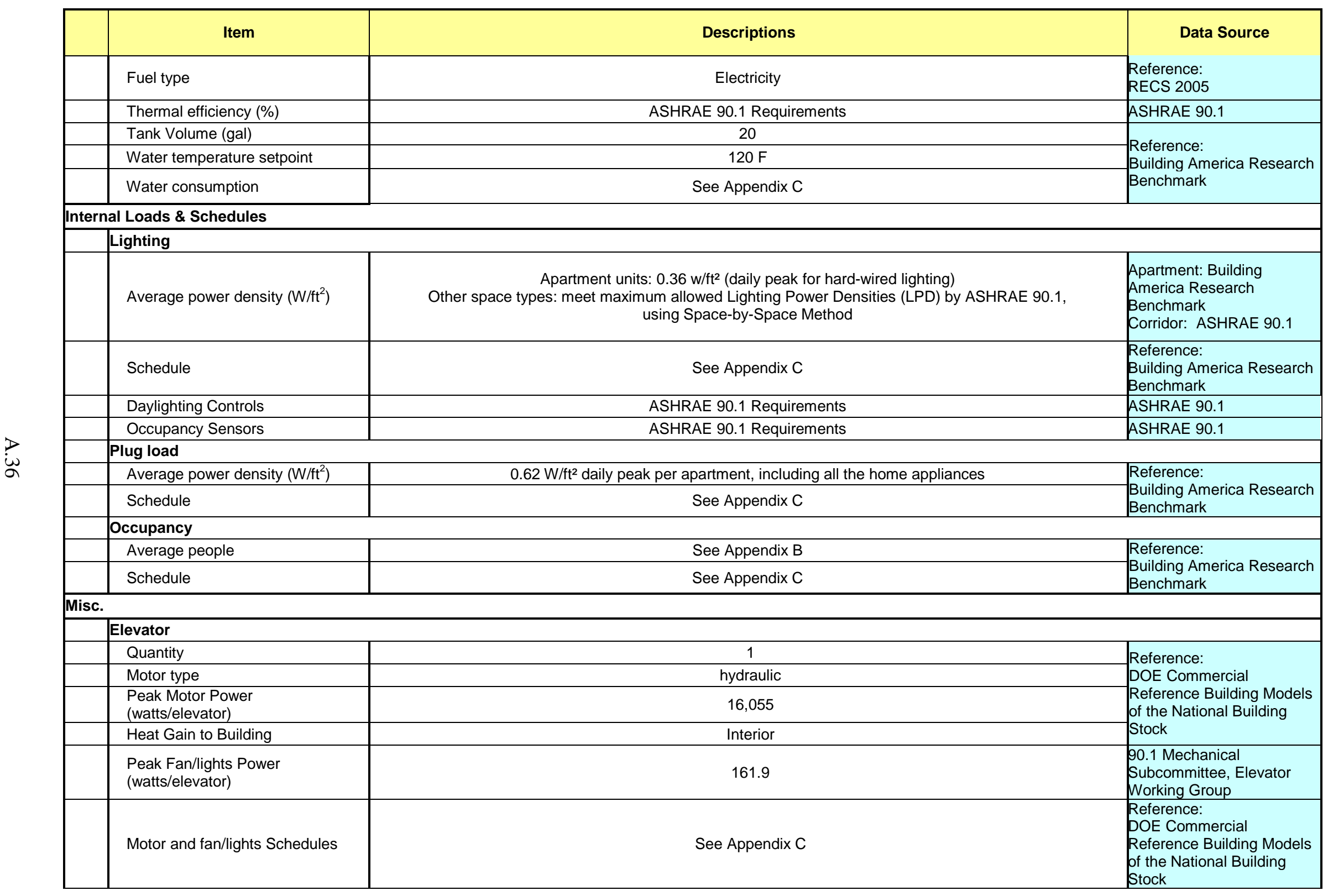




\begin{tabular}{|l|l|l|l|}
\multicolumn{1}{|c|}{ Item } & \multicolumn{2}{c|}{ Descriptions } \\
\hline & \multicolumn{1}{|c|}{ Data Source } \\
\hline & Exterior Lighting & & \\
\hline & Peak Power $(\mathrm{W})$ & 4,642 & SSHRAE 90.1 \\
\hline
\end{tabular}

References

Briggs, R.S., R.G. Lucas, and Z.T. Taylor. 2003. Climate Classification for Building Energy Codes and Standards: Part 2-Zone Definitions, Maps, and Comparisons. ASHRAE Transactions 109(2).

Gowri K, MA Halverson, and EE Richman. 2007. Analysis of Energy Saving Impacts of ASHRAE 90.1-2004 for New York. PNNL-16770, Pacific Northwest National Laboratory, Richland, WA. http://www.pnl.gov/main/publications/external/technical reports/PNNL-16770.pdf

Gowri K, DW Winiarski, and RE Jarnagin. 2009. Infiltration modeling guidelines for commercial building energy analysis. PNNL-18898, Pacific Northwest National Laboratory, Richland, WA. http://www.pnl.gov/main/publications/external/technical_reports/PNNL-18898.pdf

Building America Research Benchmark. http://www1.eere.energy.gov/buildings/building_america/index.html

DOE Commercial Reference Building Models of the National Building Stock: http://www.nrel.gov/docs/fy11osti/46861.pdf

RECS 2005 EIA's Residential Energy Consumption Survey. http://www.eia.doe.gov/emeu/recs/ 
Appendix B

Incremental Cost Estimate Summary 


\section{B.1 Small Office Cost Summary}

\begin{tabular}{|c|c|c|c|c|c|c|c|c|c|c|}
\hline \multirow[t]{2}{*}{ Small Office } & \multicolumn{5}{|c|}{ HVAC } & \multicolumn{5}{|c|}{ Lighting } \\
\hline & $\begin{array}{c}2 \mathrm{~A} \\
\text { Houston }\end{array}$ & $\begin{array}{c}3 \mathrm{~A} \\
\text { Memphis }\end{array}$ & $\begin{array}{c}\text { 3B } \\
\text { El Paso }\end{array}$ & $\begin{array}{c}4 \mathrm{~A} \\
\text { Baltimore }\end{array}$ & $\begin{array}{c}5 \mathrm{~A} \\
\text { Chicago }\end{array}$ & $\begin{array}{c}2 \mathrm{~A} \\
\text { Houston }\end{array}$ & $\begin{array}{c}\text { 3A } \\
\text { Memphis }\end{array}$ & $\begin{array}{c}\text { 3B } \\
\text { El Paso }\end{array}$ & $\begin{array}{c}\text { 4A } \\
\text { Baltimore }\end{array}$ & $\begin{array}{c}5 \mathrm{~A} \\
\text { Chicago }\end{array}$ \\
\hline New Construction & $-\$ 1,717$ & $-\$ 3,592$ & $-\$ 2,418$ & $-\$ 2,039$ & $-\$ 3,719$ & $\$ 10,054$ & $\$ 10,054$ & $\$ 10,054$ & $\$ 10,054$ & $\$ 10,054$ \\
\hline Maintenance & $\$ 0$ & $\$ 0$ & $\$ 0$ & $\$ 0$ & $\$ 0$ & $\$ 0$ & $\$ 0$ & $\$ 0$ & $\$ 0$ & $\$ 0$ \\
\hline \multicolumn{11}{|l|}{ Replacement (Year) } \\
\hline 1 & $\$ 0$ & $\$ 0$ & $\$ 0$ & $\$ 0$ & $\$ 0$ & $\$ 47$ & $\$ 47$ & $\$ 47$ & $\$ 47$ & $\$ 47$ \\
\hline 2 & $\$ 0$ & $\$ 0$ & $\$ 0$ & $\$ 0$ & $\$ 0$ & $-\$ 637$ & $-\$ 637$ & $-\$ 637$ & $-\$ 637$ & $-\$ 637$ \\
\hline 3 & $\$ 0$ & $\$ 0$ & $\$ 0$ & $\$ 0$ & $\$ 0$ & $\$ 44$ & $\$ 44$ & $\$ 44$ & $\$ 44$ & $\$ 44$ \\
\hline 4 & $\$ 0$ & $\$ 0$ & $\$ 0$ & $\$ 0$ & $\$ 0$ & $-\$ 502$ & $-\$ 502$ & $-\$ 502$ & $-\$ 502$ & $-\$ 502$ \\
\hline 5 & $\$ 0$ & $\$ 0$ & $\$ 0$ & $\$ 0$ & $\$ 0$ & $\$ 392$ & $\$ 392$ & $\$ 392$ & $\$ 392$ & $\$ 392$ \\
\hline 6 & $\$ 0$ & $\$ 0$ & $\$ 0$ & $\$ 0$ & $\$ 0$ & $-\$ 640$ & $-\$ 640$ & $-\$ 640$ & $-\$ 640$ & $-\$ 640$ \\
\hline 7 & $\$ 0$ & $\$ 0$ & $\$ 0$ & $\$ 0$ & $\$ 0$ & $\$ 47$ & $\$ 47$ & $\$ 47$ & $\$ 47$ & $\$ 47$ \\
\hline 8 & $\$ 0$ & $\$ 0$ & $\$ 0$ & $\$ 0$ & $\$ 0$ & $-\$ 502$ & $-\$ 502$ & $-\$ 502$ & $-\$ 502$ & $-\$ 502$ \\
\hline 9 & $\$ 0$ & $\$ 0$ & $\$ 0$ & $\$ 0$ & $\$ 0$ & $-\$ 39$ & $-\$ 39$ & $-\$ 39$ & $-\$ 39$ & $-\$ 39$ \\
\hline 10 & $\$ 0$ & $\$ 0$ & $\$ 0$ & $\$ 0$ & $\$ 0$ & $-\$ 384$ & $-\$ 384$ & $-\$ 384$ & $-\$ 384$ & $-\$ 384$ \\
\hline 11 & $\$ 0$ & $\$ 0$ & $\$ 0$ & $\$ 0$ & $\$ 0$ & $-\$ 2,253$ & $-\$ 2,253$ & $-\$ 2,253$ & $-\$ 2,253$ & $-\$ 2,253$ \\
\hline 12 & $\$ 0$ & $\$ 0$ & $\$ 0$ & $\$ 0$ & $\$ 0$ & $-\$ 506$ & $-\$ 506$ & $-\$ 506$ & $-\$ 506$ & $-\$ 506$ \\
\hline 13 & $\$ 0$ & $\$ 0$ & $\$ 0$ & $\$ 0$ & $\$ 0$ & $\$ 47$ & $\$ 47$ & $\$ 47$ & $\$ 47$ & $\$ 47$ \\
\hline 14 & $\$ 0$ & $\$ 0$ & $\$ 0$ & $\$ 0$ & $\$ 0$ & $-\$ 1,538$ & $-\$ 1,538$ & $-\$ 1,538$ & $-\$ 1,538$ & $-\$ 1,538$ \\
\hline 15 & $-\$ 2,103$ & $-\$ 4,017$ & $-\$ 2,103$ & $-\$ 957$ & $-\$ 4,017$ & $\$ 8,025$ & $\$ 8,025$ & $\$ 8,025$ & $\$ 8,025$ & $\$ 8,025$ \\
\hline 16 & $\$ 0$ & $\$ 0$ & $\$ 0$ & $\$ 0$ & $\$ 0$ & $-\$ 502$ & $-\$ 502$ & $-\$ 502$ & $-\$ 502$ & $-\$ 502$ \\
\hline 17 & $\$ 0$ & $\$ 0$ & $\$ 0$ & $\$ 0$ & $\$ 0$ & $\$ 47$ & $\$ 47$ & $\$ 47$ & $\$ 47$ & $\$ 47$ \\
\hline 18 & $\$ 0$ & $\$ 0$ & $\$ 0$ & $\$ 0$ & $\$ 0$ & $\$ 1,185$ & $\$ 1,185$ & $\$ 1,185$ & $\$ 1,185$ & $\$ 1,185$ \\
\hline 19 & $\$ 0$ & $\$ 0$ & $\$ 0$ & $\$ 0$ & $\$ 0$ & $\$ 47$ & $\$ 47$ & $\$ 47$ & $\$ 47$ & $\$ 47$ \\
\hline 20 & $\$ 0$ & $\$ 0$ & $\$ 0$ & $\$ 0$ & $\$ 0$ & $-\$ 249$ & $-\$ 249$ & $-\$ 249$ & $-\$ 249$ & $-\$ 249$ \\
\hline 21 & $\$ 0$ & $\$ 0$ & $\$ 0$ & $\$ 0$ & $\$ 0$ & $\$ 44$ & $\$ 44$ & $\$ 44$ & $\$ 44$ & $\$ 44$ \\
\hline 22 & $\$ 0$ & $\$ 0$ & $\$ 0$ & $\$ 0$ & $\$ 0$ & $-\$ 2,937$ & $-\$ 2,937$ & $-\$ 2,937$ & $-\$ 2,937$ & $-\$ 2,937$ \\
\hline 23 & $\$ 0$ & $\$ 0$ & $\$ 0$ & $\$ 0$ & $\$ 0$ & $\$ 214$ & $\$ 214$ & $\$ 214$ & $\$ 214$ & $\$ 214$ \\
\hline 24 & $\$ 0$ & $\$ 0$ & $\$ 0$ & $\$ 0$ & $\$ 0$ & $-\$ 506$ & $-\$ 506$ & $-\$ 506$ & $-\$ 506$ & $-\$ 506$ \\
\hline 25 & $\$ 0$ & $\$ 0$ & $\$ 0$ & $\$ 0$ & $\$ 0$ & $\$ 392$ & $\$ 392$ & $\$ 392$ & $\$ 392$ & $\$ 392$ \\
\hline 26 & $\$ 0$ & $\$ 0$ & $\$ 0$ & $\$ 0$ & $\$ 0$ & $-\$ 637$ & $-\$ 637$ & $-\$ 637$ & $-\$ 637$ & $-\$ 637$ \\
\hline 27 & $\$ 0$ & $\$ 0$ & $\$ 0$ & $\$ 0$ & $\$ 0$ & $-\$ 39$ & $-\$ 39$ & $-\$ 39$ & $-\$ 39$ & $-\$ 39$ \\
\hline 28 & $\$ 0$ & $\$ 0$ & $\$ 0$ & $\$ 0$ & $\$ 0$ & $-\$ 1,404$ & $-\$ 1,404$ & $-\$ 1,404$ & $-\$ 1,404$ & $-\$ 1,404$ \\
\hline 29 & $\$ 0$ & $\$ 0$ & $\$ 0$ & $\$ 0$ & $\$ 0$ & $\$ 47$ & $\$ 47$ & $\$ 47$ & $\$ 47$ & $\$ 47$ \\
\hline 30 & $\$ 0$ & $\$ 0$ & $\$ 0$ & $\$ 0$ & $\$ 0$ & $\$ 636$ & $\$ 636$ & $\$ 636$ & $\$ 636$ & $\$ 636$ \\
\hline
\end{tabular}


Small Office

Envelope, Power and Other

Total

\begin{tabular}{|c|c|c|c|c|c|c|c|c|c|c|}
\hline & & & & & & & & & & \\
\hline & $\begin{array}{c}2 \mathrm{~A} \\
\text { Houston }\end{array}$ & $\begin{array}{c}\text { 3A } \\
\text { Memphis }\end{array}$ & $\begin{array}{c}\text { 3B } \\
\text { El Paso }\end{array}$ & $\begin{array}{c}\text { 4A } \\
\text { Baltimore }\end{array}$ & $\begin{array}{c}5 \mathrm{~A} \\
\text { Chicago }\end{array}$ & $\begin{array}{c}2 \mathrm{~A} \\
\text { Houston }\end{array}$ & $\begin{array}{c}\text { 3A } \\
\text { Memphis }\end{array}$ & $\begin{array}{c}3 \mathrm{~B} \\
\text { El Paso }\end{array}$ & $\begin{array}{c}\text { 4A } \\
\text { Baltimore }\end{array}$ & $\begin{array}{c}5 \mathrm{~A} \\
\text { Chicago }\end{array}$ \\
\hline New Construction & $\$ 2,287$ & $\$ 2,287$ & $\$ 2,287$ & $\$ 7,096$ & $\$ 2,287$ & $\$ 10,624.3$ & $\$ 8,749$ & $\$ 9,923$ & $\$ 15,112$ & $\$ 8,622$ \\
\hline Maintenance & $\$ 0$ & $\$ 0$ & $\$ 0$ & $\$ 0$ & $\$ 0$ & $\$ 0$ & $\$ 0$ & $\$ 0$ & $\$ 0$ & $\$ 0$ \\
\hline Replacement (Year) & & & & & & $\$ 0$ & $\$ 0$ & $\$ 0$ & $\$ 0$ & $\$ 0$ \\
\hline 1 & $\$ 0$ & $\$ 0$ & $\$ 0$ & $\$ 0$ & $\$ 0$ & $\$ 47$ & $\$ 47$ & $\$ 47$ & $\$ 47$ & $\$ 47$ \\
\hline 2 & $\$ 0$ & $\$ 0$ & $\$ 0$ & $\$ 0$ & $\$ 0$ & $-\$ 637$ & $-\$ 637$ & $-\$ 637$ & $-\$ 637$ & $-\$ 637$ \\
\hline 3 & $\$ 0$ & $\$ 0$ & $\$ 0$ & $\$ 0$ & $\$ 0$ & $\$ 44$ & $\$ 44$ & $\$ 44$ & $\$ 44$ & $\$ 44$ \\
\hline 4 & $\$ 0$ & $\$ 0$ & $\$ 0$ & $\$ 0$ & $\$ 0$ & $-\$ 502$ & $-\$ 502$ & $-\$ 502$ & $-\$ 502$ & $-\$ 502$ \\
\hline 5 & $\$ 0$ & $\$ 0$ & $\$ 0$ & $\$ 0$ & $\$ 0$ & $\$ 392$ & $\$ 392$ & $\$ 392$ & $\$ 392$ & $\$ 392$ \\
\hline 6 & $\$ 0$ & $\$ 0$ & $\$ 0$ & $\$ 0$ & $\$ 0$ & $-\$ 640$ & $-\$ 640$ & $-\$ 640$ & $-\$ 640$ & $-\$ 640$ \\
\hline 7 & $\$ 0$ & $\$ 0$ & $\$ 0$ & $\$ 0$ & $\$ 0$ & $\$ 47$ & $\$ 47$ & $\$ 47$ & $\$ 47$ & $\$ 47$ \\
\hline 8 & $\$ 0$ & $\$ 0$ & $\$ 0$ & $\$ 0$ & $\$ 0$ & $-\$ 502$ & $-\$ 502$ & $-\$ 502$ & $-\$ 502$ & $-\$ 502$ \\
\hline 9 & $\$ 0$ & $\$ 0$ & $\$ 0$ & $\$ 0$ & $\$ 0$ & $-\$ 39$ & $-\$ 39$ & $-\$ 39$ & $-\$ 39$ & $-\$ 39$ \\
\hline 10 & $\$ 0$ & $\$ 0$ & $\$ 0$ & $\$ 0$ & $\$ 0$ & $-\$ 384$ & $-\$ 384$ & $-\$ 384$ & $-\$ 384$ & $-\$ 384$ \\
\hline 11 & $\$ 0$ & $\$ 0$ & $\$ 0$ & $\$ 0$ & $\$ 0$ & $-\$ 2,253$ & $-\$ 2,253$ & $-\$ 2,253$ & $-\$ 2,253$ & $-\$ 2,253$ \\
\hline 12 & $\$ 0$ & $\$ 0$ & $\$ 0$ & $\$ 0$ & $\$ 0$ & $-\$ 506$ & $-\$ 506$ & $-\$ 506$ & $-\$ 506$ & $-\$ 506$ \\
\hline 13 & $\$ 0$ & $\$ 0$ & $\$ 0$ & $\$ 0$ & $\$ 0$ & $\$ 47$ & $\$ 47$ & $\$ 47$ & $\$ 47$ & $\$ 47$ \\
\hline 14 & $\$ 0$ & $\$ 0$ & $\$ 0$ & $\$ 0$ & $\$ 0$ & $-\$ 1,538$ & $-\$ 1,538$ & $-\$ 1,538$ & $-\$ 1,538$ & $-\$ 1,538$ \\
\hline 15 & $\$ 0$ & $\$ 0$ & $\$ 0$ & $\$ 0$ & $\$ 0$ & $\$ 5,921$ & $\$ 4,008$ & $\$ 5,921$ & $\$ 7,068$ & $\$ 4,008$ \\
\hline 16 & $\$ 0$ & $\$ 0$ & $\$ 0$ & $\$ 0$ & $\$ 0$ & $-\$ 502$ & $-\$ 502$ & $-\$ 502$ & $-\$ 502$ & $-\$ 502$ \\
\hline 17 & $\$ 0$ & $\$ 0$ & $\$ 0$ & $\$ 0$ & $\$ 0$ & $\$ 47$ & $\$ 47$ & $\$ 47$ & $\$ 47$ & $\$ 47$ \\
\hline 18 & $\$ 0$ & $\$ 0$ & $\$ 0$ & $\$ 0$ & $\$ 0$ & $\$ 1,185$ & $\$ 1,185$ & $\$ 1,185$ & $\$ 1,185$ & $\$ 1,185$ \\
\hline 19 & $\$ 0$ & $\$ 0$ & $\$ 0$ & $\$ 0$ & $\$ 0$ & $\$ 47$ & $\$ 47$ & $\$ 47$ & $\$ 47$ & $\$ 47$ \\
\hline 20 & $-\$ 101$ & $-\$ 101$ & $-\$ 101$ & $-\$ 101$ & $-\$ 101$ & $-\$ 350$ & $-\$ 350$ & $-\$ 350$ & $-\$ 350$ & $-\$ 350$ \\
\hline 21 & $\$ 0$ & $\$ 0$ & $\$ 0$ & $\$ 0$ & $\$ 0$ & $\$ 44$ & $\$ 44$ & $\$ 44$ & $\$ 44$ & $\$ 44$ \\
\hline 22 & $\$ 0$ & $\$ 0$ & $\$ 0$ & $\$ 0$ & $\$ 0$ & $-\$ 2,937$ & $-\$ 2,937$ & $-\$ 2,937$ & $-\$ 2,937$ & $-\$ 2,937$ \\
\hline 23 & $\$ 0$ & $\$ 0$ & $\$ 0$ & $\$ 0$ & $\$ 0$ & $\$ 214$ & $\$ 214$ & $\$ 214$ & $\$ 214$ & $\$ 214$ \\
\hline 24 & $\$ 0$ & $\$ 0$ & $\$ 0$ & $\$ 0$ & $\$ 0$ & $-\$ 506$ & $-\$ 506$ & $-\$ 506$ & $-\$ 506$ & $-\$ 506$ \\
\hline 25 & $\$ 0$ & $\$ 0$ & $\$ 0$ & $\$ 0$ & $\$ 0$ & $\$ 392$ & $\$ 392$ & $\$ 392$ & $\$ 392$ & $\$ 392$ \\
\hline 26 & $\$ 0$ & $\$ 0$ & $\$ 0$ & $\$ 0$ & $\$ 0$ & $-\$ 637$ & $-\$ 637$ & $-\$ 637$ & $-\$ 637$ & $-\$ 637$ \\
\hline 27 & $\$ 0$ & $\$ 0$ & $\$ 0$ & $\$ 0$ & $\$ 0$ & $-\$ 39$ & $-\$ 39$ & $-\$ 39$ & $-\$ 39$ & $-\$ 39$ \\
\hline 28 & $\$ 0$ & $\$ 0$ & $\$ 0$ & $\$ 0$ & $\$ 0$ & $-\$ 1,404$ & $-\$ 1,404$ & $-\$ 1,404$ & $-\$ 1,404$ & $-\$ 1,404$ \\
\hline 29 & $\$ 0$ & $\$ 0$ & $\$ 0$ & $\$ 0$ & $\$ 0$ & $\$ 47$ & $\$ 47$ & $\$ 47$ & $\$ 47$ & $\$ 47$ \\
\hline 30 & $\$ 47$ & $\$ 47$ & $\$ 47$ & $-\$ 1,467$ & $\$ 47$ & $\$ 683$ & $\$ 683$ & $\$ 683$ & $-\$ 831$ & $\$ 683$ \\
\hline
\end{tabular}




\section{B.2 Large Office Cost Summary}

\begin{tabular}{|c|c|c|c|c|c|c|c|c|c|c|}
\hline \multirow[t]{2}{*}{ Large Office } & \multicolumn{5}{|c|}{ HVAC } & \multicolumn{5}{|c|}{ Lighting } \\
\hline & $\begin{array}{c}2 \mathrm{~A} \\
\text { Houston }\end{array}$ & $\begin{array}{c}\text { 3A } \\
\text { Memphis }\end{array}$ & $\begin{array}{c}\text { 3B } \\
\text { El Paso }\end{array}$ & $\begin{array}{c}\text { 4A } \\
\text { Baltimore }\end{array}$ & $\begin{array}{c}5 \mathrm{~A} \\
\text { Chicago }\end{array}$ & $\begin{array}{c}2 \mathrm{~A} \\
\text { Houston }\end{array}$ & $\begin{array}{c}\text { 3A } \\
\text { Memphis }\end{array}$ & $\begin{array}{c}\text { 3B } \\
\text { El Paso }\end{array}$ & $\begin{array}{c}\text { 4A } \\
\text { Baltimore }\end{array}$ & $\begin{array}{c}5 \mathrm{~A} \\
\text { Chicago }\end{array}$ \\
\hline New Construction & $\$ 89,868$ & $\$ 160,488$ & $\$ 94,070$ & $\$ 134,464$ & $-\$ 109,029$ & $\$ 131,785$ & $\$ 131,785$ & $\$ 131,785$ & $\$ 131,785$ & $\$ 131,785$ \\
\hline Maintenance & $\$ 3,751$ & $\$ 3,649$ & $\$ 3,754$ & $\$ 3,628$ & $\$ 74$ & $\$ 0$ & $\$ 0$ & $\$ 0$ & $\$ 0$ & $\$ 0$ \\
\hline \multicolumn{11}{|l|}{ Replacement (Year) } \\
\hline 1 & $\$ 0$ & $\$ 0$ & $\$ 0$ & $\$ 0$ & $\$ 0$ & $\$ 1,031$ & $\$ 1,031$ & $\$ 1,031$ & $\$ 1,031$ & $\$ 1,031$ \\
\hline 2 & $\$ 0$ & $\$ 0$ & $\$ 0$ & $\$ 0$ & $\$ 0$ & $\$ 85,449$ & $\$ 85,449$ & $\$ 85,449$ & $\$ 85,449$ & $\$ 85,449$ \\
\hline 3 & $\$ 0$ & $\$ 0$ & $\$ 0$ & $\$ 0$ & $\$ 0$ & $-\$ 76,551$ & $-\$ 76,551$ & $-\$ 76,551$ & $-\$ 76,551$ & $-\$ 76,551$ \\
\hline 4 & $\$ 0$ & $\$ 0$ & $\$ 0$ & $\$ 0$ & $\$ 0$ & $\$ 44,247$ & $\$ 44,247$ & $\$ 44,247$ & $\$ 44,247$ & $\$ 44,247$ \\
\hline 5 & $\$ 0$ & $\$ 0$ & $\$ 0$ & $\$ 0$ & $\$ 0$ & $\$ 16,078$ & $\$ 16,078$ & $\$ 16,078$ & $\$ 16,078$ & $\$ 16,078$ \\
\hline 6 & $\$ 0$ & $\$ 0$ & $\$ 0$ & $\$ 0$ & $\$ 0$ & $\$ 7,868$ & $\$ 7,868$ & $\$ 7,868$ & $\$ 7,868$ & $\$ 7,868$ \\
\hline 7 & $\$ 0$ & $\$ 0$ & $\$ 0$ & $\$ 0$ & $\$ 0$ & $-\$ 14,089$ & $-\$ 14,089$ & $-\$ 14,089$ & $-\$ 14,089$ & $-\$ 14,089$ \\
\hline 8 & $\$ 0$ & $\$ 0$ & $\$ 0$ & $\$ 0$ & $\$ 0$ & $\$ 44,247$ & $\$ 44,247$ & $\$ 44,247$ & $\$ 44,247$ & $\$ 44,247$ \\
\hline 9 & $\$ 0$ & $\$ 0$ & $\$ 0$ & $\$ 0$ & $\$ 0$ & $-\$ 75,066$ & $-\$ 75,066$ & $-\$ 75,066$ & $-\$ 75,066$ & $-\$ 75,066$ \\
\hline 10 & $\$ 0$ & $\$ 0$ & $\$ 0$ & $\$ 0$ & $\$ 0$ & $\$ 528,129$ & $\$ 528,129$ & $\$ 528,129$ & $\$ 528,129$ & $\$ 528,129$ \\
\hline 11 & $\$ 0$ & $\$ 0$ & $\$ 0$ & $\$ 0$ & $\$ 0$ & $-\$ 37,845$ & $-\$ 37,845$ & $-\$ 37,845$ & $-\$ 37,845$ & $-\$ 37,845$ \\
\hline 12 & $\$ 0$ & $\$ 0$ & $\$ 0$ & $\$ 0$ & $\$ 0$ & $-\$ 483,725$ & $-\$ 483,725$ & $-\$ 483,725$ & $-\$ 483,725$ & $-\$ 483,725$ \\
\hline 13 & $\$ 0$ & $\$ 0$ & $\$ 0$ & $\$ 0$ & $\$ 0$ & $\$ 1,031$ & $\$ 1,031$ & $\$ 1,031$ & $\$ 1,031$ & $\$ 1,031$ \\
\hline 14 & $\$ 0$ & $\$ 0$ & $\$ 0$ & $\$ 0$ & $\$ 0$ & $-\$ 144,869$ & $-\$ 144,869$ & $-\$ 144,869$ & $-\$ 144,869$ & $-\$ 144,869$ \\
\hline 15 & $\$ 247,599$ & $\$ 229,662$ & $\$ 299,472$ & $\$ 228,213$ & $-\$ 45,961$ & $\$ 196,865$ & $\$ 196,865$ & $\$ 196,865$ & $\$ 196,865$ & $\$ 196,865$ \\
\hline 16 & $\$ 0$ & $\$ 0$ & $\$ 0$ & $\$ 0$ & $\$ 0$ & $\$ 44,247$ & $\$ 44,247$ & $\$ 44,247$ & $\$ 44,247$ & $\$ 44,247$ \\
\hline 17 & $\$ 0$ & $\$ 0$ & $\$ 0$ & $\$ 0$ & $\$ 0$ & $\$ 1,031$ & $\$ 1,031$ & $\$ 1,031$ & $\$ 1,031$ & $\$ 1,031$ \\
\hline 18 & $-\$ 12,810$ & $-\$ 15,098$ & $-\$ 27,199$ & $-\$ 12,810$ & $-\$ 15,320$ & $\$ 34,731$ & $\$ 34,731$ & $\$ 34,731$ & $\$ 34,731$ & $\$ 34,731$ \\
\hline 19 & $\$ 0$ & $\$ 0$ & $\$ 0$ & $\$ 0$ & $\$ 0$ & $\$ 1,031$ & $\$ 1,031$ & $\$ 1,031$ & $\$ 1,031$ & $\$ 1,031$ \\
\hline 20 & $-\$ 6,116$ & $-\$ 6,575$ & $\$ 7,888$ & $\$ 15,120$ & $\$ 16,038$ & $\$ 486,926$ & $\$ 486,926$ & $\$ 486,926$ & $\$ 486,926$ & $\$ 486,926$ \\
\hline 21 & $\$ 0$ & $\$ 0$ & $\$ 0$ & $\$ 0$ & $\$ 0$ & $-\$ 91,671$ & $-\$ 91,671$ & $-\$ 91,671$ & $-\$ 91,671$ & $-\$ 91,671$ \\
\hline 22 & $\$ 0$ & $\$ 0$ & $\$ 0$ & $\$ 0$ & $\$ 0$ & $\$ 46,573$ & $\$ 46,573$ & $\$ 46,573$ & $\$ 46,573$ & $\$ 46,573$ \\
\hline 23 & $-\$ 13,395$ & $-\$ 14,143$ & $\$ 20,138$ & $-\$ 13,986$ & $-\$ 14,276$ & $\$ 4,583$ & $\$ 4,583$ & $\$ 4,583$ & $\$ 4,583$ & $\$ 4,583$ \\
\hline 24 & $\$ 0$ & $\$ 0$ & $\$ 0$ & $\$ 0$ & $\$ 0$ & $-\$ 483,725$ & $-\$ 483,725$ & $-\$ 483,725$ & $-\$ 483,725$ & $-\$ 483,725$ \\
\hline 25 & $\$ 0$ & $\$ 0$ & $\$ 0$ & $\$ 0$ & $\$ 0$ & $\$ 16,078$ & $\$ 16,078$ & $\$ 16,078$ & $\$ 16,078$ & $\$ 16,078$ \\
\hline 26 & $\$ 0$ & $\$ 0$ & $\$ 0$ & $\$ 0$ & $\$ 0$ & $\$ 85,449$ & $\$ 85,449$ & $\$ 85,449$ & $\$ 85,449$ & $\$ 85,449$ \\
\hline 27 & $\$ 0$ & $\$ 0$ & $\$ 0$ & $\$ 0$ & $\$ 0$ & $-\$ 75,066$ & $-\$ 75,066$ & $-\$ 75,066$ & $-\$ 75,066$ & $-\$ 75,066$ \\
\hline 28 & $\$ 0$ & $\$ 0$ & $\$ 0$ & $\$ 0$ & $\$ 0$ & $-\$ 186,071$ & $-\$ 186,071$ & $-\$ 186,071$ & $-\$ 186,071$ & $-\$ 186,071$ \\
\hline 29 & $\$ 0$ & $\$ 0$ & $\$ 0$ & $\$ 0$ & $\$ 0$ & $\$ 1,031$ & $\$ 1,031$ & $\$ 1,031$ & $\$ 1,031$ & $\$ 1,031$ \\
\hline 30 & $\$ 22,495$ & $\$ 24,299$ & $\$ 3,355$ & $\$ 12,452$ & $\$ 13,034$ & $\$ 439,733$ & $\$ 439,733$ & $\$ 439,733$ & $\$ 439,733$ & $\$ 439,733$ \\
\hline
\end{tabular}


Envelope, Power and Other

Total

\begin{tabular}{|c|c|c|c|c|c|c|c|c|c|c|}
\hline & \multicolumn{5}{|c|}{ Eirverope, rower dalu Unter } & \\
\hline & $\begin{array}{c}2 \mathrm{~A} \\
\text { Houston }\end{array}$ & $\begin{array}{c}\text { 3A } \\
\text { Memphis }\end{array}$ & $\begin{array}{c}\text { 3B } \\
\text { El Paso } \\
\end{array}$ & $\begin{array}{c}4 \mathrm{~A} \\
\text { Baltimore } \\
\end{array}$ & $\begin{array}{c}5 \mathrm{~A} \\
\text { Chicago } \\
\end{array}$ & $\begin{array}{c}2 \mathrm{~A} \\
\text { Houston }\end{array}$ & $\begin{array}{c}\text { 3A } \\
\text { Memphis }\end{array}$ & $\begin{array}{c}3 \mathrm{~B} \\
\text { El Paso } \\
\end{array}$ & $\begin{array}{c}4 \mathrm{~A} \\
\text { Baltimore }\end{array}$ & $\begin{array}{c}5 \mathrm{~A} \\
\text { Chicago } \\
\end{array}$ \\
\hline New Construction & $\$ 225,318$ & $\$ 225,318$ & $\$ 225,318$ & $\$ 225,318$ & $\$ 225,318$ & $\$ 446,971$ & $\$ 517,591$ & $\$ 451,173$ & $\$ 491,567$ & $\$ 248,074$ \\
\hline Maintenance & $\$ 0$ & $\$ 0$ & $\$ 0$ & $\$ 0$ & $\$ 0$ & $\$ 3,751$ & $\$ 3,649$ & $\$ 3,754$ & $\$ 3,628$ & $\$ 74$ \\
\hline Replacement (Year) & & & & & & $\$ 0$ & $\$ 0$ & $\$ 0$ & $\$ 0$ & $\$ 0$ \\
\hline 1 & $-\$ 3,942$ & $-\$ 3,942$ & $-\$ 3,942$ & $-\$ 3,942$ & $-\$ 3,942$ & $-\$ 2,911$ & $-\$ 2,911$ & $-\$ 2,911$ & $-\$ 2,911$ & $-\$ 2,911$ \\
\hline 2 & $-\$ 3,942$ & $-\$ 3,942$ & $-\$ 3,942$ & $-\$ 3,942$ & $-\$ 3,942$ & $\$ 81,507$ & $\$ 81,507$ & $\$ 81,507$ & $\$ 81,507$ & $\$ 81,507$ \\
\hline 3 & $-\$ 3,942$ & $-\$ 3,942$ & $-\$ 3,942$ & $-\$ 3,942$ & $-\$ 3,942$ & $-\$ 80,492$ & $-\$ 80,492$ & $-\$ 80,492$ & $-\$ 80,492$ & $-\$ 80,492$ \\
\hline 4 & $-\$ 3,942$ & $-\$ 3,942$ & $-\$ 3,942$ & $-\$ 3,942$ & $-\$ 3,942$ & $\$ 40,305$ & $\$ 40,305$ & $\$ 40,305$ & $\$ 40,305$ & $\$ 40,305$ \\
\hline 5 & $-\$ 5,278$ & $-\$ 5,278$ & $-\$ 5,278$ & $-\$ 5,278$ & $-\$ 5,278$ & $\$ 10,800$ & $\$ 10,800$ & $\$ 10,800$ & $\$ 10,800$ & $\$ 10,800$ \\
\hline 6 & $-\$ 3,942$ & $-\$ 3,942$ & $-\$ 3,942$ & $-\$ 3,942$ & $-\$ 3,942$ & $\$ 3,926$ & $\$ 3,926$ & $\$ 3,926$ & $\$ 3,926$ & $\$ 3,926$ \\
\hline 7 & $-\$ 3,942$ & $-\$ 3,942$ & $-\$ 3,942$ & $-\$ 3,942$ & $-\$ 3,942$ & $-\$ 18,031$ & $-\$ 18,031$ & $-\$ 18,031$ & $-\$ 18,031$ & $-\$ 18,031$ \\
\hline 8 & $-\$ 3,942$ & $-\$ 3,942$ & $-\$ 3,942$ & $-\$ 3,942$ & $-\$ 3,942$ & $\$ 40,305$ & $\$ 40,305$ & $\$ 40,305$ & $\$ 40,305$ & $\$ 40,305$ \\
\hline 9 & $-\$ 3,942$ & $-\$ 3,942$ & $-\$ 3,942$ & $-\$ 3,942$ & $-\$ 3,942$ & $-\$ 79,008$ & $-\$ 79,008$ & $-\$ 79,008$ & $-\$ 79,008$ & $-\$ 79,008$ \\
\hline 10 & $-\$ 5,278$ & $-\$ 5,278$ & $-\$ 5,278$ & $-\$ 5,278$ & $-\$ 5,278$ & $\$ 522,851$ & $\$ 522,851$ & $\$ 522,851$ & $\$ 522,851$ & $\$ 522,851$ \\
\hline 11 & $-\$ 3,942$ & $-\$ 3,942$ & $-\$ 3,942$ & $-\$ 3,942$ & $-\$ 3,942$ & $-\$ 41,786$ & $-\$ 41,786$ & $-\$ 41,786$ & $-\$ 41,786$ & $-\$ 41,786$ \\
\hline 12 & $-\$ 3,942$ & $-\$ 3,942$ & $-\$ 3,942$ & $-\$ 3,942$ & $-\$ 3,942$ & $-\$ 487,667$ & $-\$ 487,667$ & $-\$ 487,667$ & $-\$ 487,667$ & $-\$ 487,667$ \\
\hline 13 & $-\$ 3,942$ & $-\$ 3,942$ & $-\$ 3,942$ & $-\$ 3,942$ & $-\$ 3,942$ & $-\$ 2,911$ & $-\$ 2,911$ & $-\$ 2,911$ & $-\$ 2,911$ & $-\$ 2,911$ \\
\hline 14 & $-\$ 3,942$ & $-\$ 3,942$ & $-\$ 3,942$ & $-\$ 3,942$ & $-\$ 3,942$ & $-\$ 148,810$ & $-\$ 148,810$ & $-\$ 148,810$ & $-\$ 148,810$ & $-\$ 148,810$ \\
\hline 15 & $-\$ 5,278$ & $-\$ 5,278$ & $-\$ 5,278$ & $-\$ 5,278$ & $-\$ 5,278$ & $\$ 439,187$ & $\$ 421,249$ & $\$ 491,060$ & $\$ 419,801$ & $\$ 145,626$ \\
\hline 16 & $-\$ 3,942$ & $-\$ 3,942$ & $-\$ 3,942$ & $-\$ 3,942$ & $-\$ 3,942$ & $\$ 40,305$ & $\$ 40,305$ & $\$ 40,305$ & $\$ 40,305$ & $\$ 40,305$ \\
\hline 17 & $-\$ 3,942$ & $-\$ 3,942$ & $-\$ 3,942$ & $-\$ 3,942$ & $-\$ 3,942$ & $-\$ 2,911$ & $-\$ 2,911$ & $-\$ 2,911$ & $-\$ 2,911$ & $-\$ 2,911$ \\
\hline 18 & $-\$ 3,942$ & $-\$ 3,942$ & $-\$ 3,942$ & $-\$ 3,942$ & $-\$ 3,942$ & $\$ 17,980$ & $\$ 15,692$ & $\$ 3,590$ & $\$ 17,980$ & $\$ 15,469$ \\
\hline 19 & $-\$ 3,942$ & $-\$ 3,942$ & $-\$ 3,942$ & $-\$ 3,942$ & $-\$ 3,942$ & $-\$ 2,911$ & $-\$ 2,911$ & $-\$ 2,911$ & $-\$ 2,911$ & $-\$ 2,911$ \\
\hline 20 & $-\$ 22,712$ & $-\$ 22,712$ & $-\$ 22,712$ & $-\$ 22,712$ & $-\$ 22,712$ & $\$ 458,099$ & $\$ 457,640$ & $\$ 472,103$ & $\$ 479,335$ & $\$ 480,253$ \\
\hline 21 & $\$ 513$ & $\$ 513$ & $\$ 513$ & $\$ 513$ & $\$ 513$ & $-\$ 91,158$ & $-\$ 91,158$ & $-\$ 91,158$ & $-\$ 91,158$ & $-\$ 91,158$ \\
\hline 22 & $-\$ 3,942$ & $-\$ 3,942$ & $-\$ 3,942$ & $-\$ 3,942$ & $-\$ 3,942$ & $\$ 42,632$ & $\$ 42,632$ & $\$ 42,632$ & $\$ 42,632$ & $\$ 42,632$ \\
\hline 23 & $-\$ 3,942$ & $-\$ 3,942$ & $-\$ 3,942$ & $-\$ 3,942$ & $-\$ 3,942$ & $-\$ 12,753$ & $-\$ 13,501$ & $\$ 20,779$ & $-\$ 13,345$ & $-\$ 13,635$ \\
\hline 24 & $-\$ 3,942$ & $-\$ 3,942$ & $-\$ 3,942$ & $-\$ 3,942$ & $-\$ 3,942$ & $-\$ 487,667$ & $-\$ 487,667$ & $-\$ 487,667$ & $-\$ 487,667$ & $-\$ 487,667$ \\
\hline 25 & $-\$ 5,278$ & $-\$ 5,278$ & $-\$ 5,278$ & $-\$ 5,278$ & $-\$ 5,278$ & $\$ 10,800$ & $\$ 10,800$ & $\$ 10,800$ & $\$ 10,800$ & $\$ 10,800$ \\
\hline 26 & $-\$ 3,942$ & $-\$ 3,942$ & $-\$ 3,942$ & $-\$ 3,942$ & $-\$ 3,942$ & $\$ 81,507$ & $\$ 81,507$ & $\$ 81,507$ & $\$ 81,507$ & $\$ 81,507$ \\
\hline 27 & $-\$ 3,942$ & $-\$ 3,942$ & $-\$ 3,942$ & $-\$ 3,942$ & $-\$ 3,942$ & $-\$ 79,008$ & $-\$ 79,008$ & $-\$ 79,008$ & $-\$ 79,008$ & $-\$ 79,008$ \\
\hline 28 & $-\$ 3,942$ & $-\$ 3,942$ & $-\$ 3,942$ & $-\$ 3,942$ & $-\$ 3,942$ & $-\$ 190,012$ & $-\$ 190,012$ & $-\$ 190,012$ & $-\$ 190,012$ & $-\$ 190,012$ \\
\hline 29 & $-\$ 3,942$ & $-\$ 3,942$ & $-\$ 3,942$ & $-\$ 3,942$ & $-\$ 3,942$ & $-\$ 2,911$ & $-\$ 2,911$ & $-\$ 2,911$ & $-\$ 2,911$ & $-\$ 2,911$ \\
\hline 30 & $\$ 3,004$ & $\$ 3,004$ & $\$ 3,004$ & $\$ 3,004$ & $\$ 3,004$ & $\$ 465,232$ & $\$ 467,037$ & $\$ 446,092$ & $\$ 455,189$ & $\$ 455,772$ \\
\hline
\end{tabular}




\section{B.3 Standalone Retail Cost Summary}

\begin{tabular}{|c|c|c|c|c|c|c|c|c|c|c|}
\hline \multirow[t]{2}{*}{ Standalone Retail } & \multicolumn{5}{|c|}{ HVAC } & \multicolumn{5}{|c|}{ Lighting } \\
\hline & $\begin{array}{c}2 \mathrm{~A} \\
\text { Houston } \\
\end{array}$ & $\begin{array}{c}\text { 3A } \\
\text { Memphis } \\
\end{array}$ & $\begin{array}{c}\text { 3B } \\
\text { El Paso } \\
\end{array}$ & $\begin{array}{c}4 \mathrm{~A} \\
\text { Baltimore } \\
\end{array}$ & $\begin{array}{c}5 \mathrm{~A} \\
\text { Chicago } \\
\end{array}$ & $\begin{array}{c}2 \mathrm{~A} \\
\text { Houston } \\
\end{array}$ & $\begin{array}{c}\text { 3A } \\
\text { Memphis } \\
\end{array}$ & $\begin{array}{c}\text { 3B } \\
\text { El Paso } \\
\end{array}$ & $\begin{array}{c}4 \mathrm{~A} \\
\text { Baltimore } \\
\end{array}$ & $\begin{array}{c}5 \mathrm{~A} \\
\text { Chicago } \\
\end{array}$ \\
\hline New Construction & $\$ 18,389$ & $\$ 28,289$ & $\$ 4,504$ & $\$ 35,850$ & $\$ 15,582$ & $\$ 7,732$ & $\$ 7,732$ & $\$ 7,732$ & $\$ 7,732$ & $\$ 7,732$ \\
\hline Maintenance & $\$ 742$ & $\$ 767$ & $\$ 154$ & $\$ 758$ & $\$ 465$ & $\$ 0$ & $\$ 0$ & $\$ 0$ & $\$ 0$ & $\$ 0$ \\
\hline \multicolumn{11}{|l|}{ Replacement (Year) } \\
\hline 1 & $\$ 0$ & $\$ 0$ & $\$ 0$ & $\$ 0$ & $\$ 0$ & $\$ 0$ & $\$ 0$ & $\$ 0$ & $\$ 0$ & $\$ 0$ \\
\hline 2 & $\$ 0$ & $\$ 0$ & $\$ 0$ & $\$ 0$ & $\$ 0$ & $\$ 0$ & $\$ 0$ & $\$ 0$ & $\$ 0$ & $\$ 0$ \\
\hline 3 & $\$ 0$ & $\$ 0$ & $\$ 0$ & $\$ 0$ & $\$ 0$ & $-\$ 325$ & $-\$ 325$ & $-\$ 325$ & $-\$ 325$ & $-\$ 325$ \\
\hline 4 & $\$ 0$ & $\$ 0$ & $\$ 0$ & $\$ 0$ & $\$ 0$ & $-\$ 1,007$ & $-\$ 1,007$ & $-\$ 1,007$ & $-\$ 1,007$ & $-\$ 1,007$ \\
\hline 5 & $\$ 0$ & $\$ 0$ & $\$ 0$ & $\$ 0$ & $\$ 0$ & $-\$ 941$ & $-\$ 941$ & $-\$ 941$ & $-\$ 941$ & $-\$ 941$ \\
\hline 6 & $\$ 0$ & $\$ 0$ & $\$ 0$ & $\$ 0$ & $\$ 0$ & $-\$ 358$ & $-\$ 358$ & $-\$ 358$ & $-\$ 358$ & $-\$ 358$ \\
\hline 7 & $\$ 0$ & $\$ 0$ & $\$ 0$ & $\$ 0$ & $\$ 0$ & $\$ 551$ & $\$ 551$ & $\$ 551$ & $\$ 551$ & $\$ 551$ \\
\hline 8 & $\$ 0$ & $\$ 0$ & $\$ 0$ & $\$ 0$ & $\$ 0$ & $-\$ 1,007$ & $-\$ 1,007$ & $-\$ 1,007$ & $-\$ 1,007$ & $-\$ 1,007$ \\
\hline 9 & $\$ 0$ & $\$ 0$ & $\$ 0$ & $\$ 0$ & $\$ 0$ & $-\$ 408$ & $-\$ 408$ & $-\$ 408$ & $-\$ 408$ & $-\$ 408$ \\
\hline 10 & $\$ 0$ & $\$ 0$ & $\$ 0$ & $\$ 0$ & $\$ 0$ & $-\$ 1,770$ & $-\$ 1,770$ & $-\$ 1,770$ & $-\$ 1,770$ & $-\$ 1,770$ \\
\hline 11 & $\$ 0$ & $\$ 0$ & $\$ 0$ & $\$ 0$ & $\$ 0$ & $-\$ 3,868$ & $-\$ 3,868$ & $-\$ 3,868$ & $-\$ 3,868$ & $-\$ 3,868$ \\
\hline 12 & $\$ 0$ & $\$ 0$ & $\$ 0$ & $\$ 0$ & $\$ 0$ & $-\$ 1,366$ & $-\$ 1,366$ & $-\$ 1,366$ & $-\$ 1,366$ & $-\$ 1,366$ \\
\hline 13 & $\$ 0$ & $\$ 0$ & $\$ 0$ & $\$ 0$ & $\$ 0$ & $\$ 0$ & $\$ 0$ & $\$ 0$ & $\$ 0$ & $\$ 0$ \\
\hline 14 & $\$ 0$ & $\$ 0$ & $\$ 0$ & $\$ 0$ & $\$ 0$ & $-\$ 4,385$ & $-\$ 4,385$ & $-\$ 4,385$ & $-\$ 4,385$ & $-\$ 4,385$ \\
\hline 15 & $\$ 27,827$ & $\$ 32,158$ & $\$ 7,872$ & $\$ 29,964$ & $\$ 15,401$ & $\$ 2,291$ & $\$ 2,291$ & $\$ 2,291$ & $\$ 2,291$ & $\$ 2,291$ \\
\hline 16 & $\$ 0$ & $\$ 0$ & $\$ 0$ & $\$ 0$ & $\$ 0$ & $-\$ 1,007$ & $-\$ 1,007$ & $-\$ 1,007$ & $-\$ 1,007$ & $-\$ 1,007$ \\
\hline 17 & $\$ 0$ & $\$ 0$ & $\$ 0$ & $\$ 0$ & $\$ 0$ & $\$ 0$ & $\$ 0$ & $\$ 0$ & $\$ 0$ & $\$ 0$ \\
\hline 18 & $-\$ 1,182$ & $\$ 271$ & $\$ 478$ & $\$ 551$ & $\$ 515$ & $\$ 2,593$ & $\$ 2,593$ & $\$ 2,593$ & $\$ 2,593$ & $\$ 2,593$ \\
\hline 19 & $\$ 0$ & $\$ 0$ & $\$ 0$ & $\$ 0$ & $\$ 0$ & $\$ 0$ & $\$ 0$ & $\$ 0$ & $\$ 0$ & $\$ 0$ \\
\hline 20 & $\$ 1,406$ & $\$ 1,406$ & $\$ 829$ & $\$ 1,406$ & $\$ 1,208$ & $-\$ 2,778$ & $-\$ 2,778$ & $-\$ 2,778$ & $-\$ 2,778$ & $-\$ 2,778$ \\
\hline 21 & $\$ 0$ & $\$ 0$ & $\$ 0$ & $\$ 0$ & $\$ 0$ & $\$ 226$ & $\$ 226$ & $\$ 226$ & $\$ 226$ & $\$ 226$ \\
\hline 22 & $\$ 0$ & $\$ 0$ & $\$ 0$ & $\$ 0$ & $\$ 0$ & $-\$ 3,868$ & $-\$ 3,868$ & $-\$ 3,868$ & $-\$ 3,868$ & $-\$ 3,868$ \\
\hline 23 & $\$ 0$ & $\$ 0$ & $\$ 0$ & $\$ 0$ & $\$ 0$ & $\$ 364$ & $\$ 364$ & $\$ 364$ & $\$ 364$ & $\$ 364$ \\
\hline 24 & $\$ 0$ & $\$ 0$ & $\$ 0$ & $\$ 0$ & $\$ 0$ & $-\$ 1,366$ & $-\$ 1,366$ & $-\$ 1,366$ & $-\$ 1,366$ & $-\$ 1,366$ \\
\hline 25 & $\$ 0$ & $\$ 0$ & $\$ 0$ & $\$ 0$ & $\$ 0$ & $-\$ 941$ & $-\$ 941$ & $-\$ 941$ & $-\$ 941$ & $-\$ 941$ \\
\hline 26 & $\$ 0$ & $\$ 0$ & $\$ 0$ & $\$ 0$ & $\$ 0$ & $\$ 0$ & $\$ 0$ & $\$ 0$ & $\$ 0$ & $\$ 0$ \\
\hline 27 & $\$ 0$ & $\$ 0$ & $\$ 0$ & $\$ 0$ & $\$ 0$ & $-\$ 408$ & $-\$ 408$ & $-\$ 408$ & $-\$ 408$ & $-\$ 408$ \\
\hline 28 & $\$ 0$ & $\$ 0$ & $\$ 0$ & $\$ 0$ & $\$ 0$ & $-\$ 5,393$ & $-\$ 5,393$ & $-\$ 5,393$ & $-\$ 5,393$ & $-\$ 5,393$ \\
\hline 29 & $\$ 0$ & $\$ 0$ & $\$ 0$ & $\$ 0$ & $\$ 0$ & $\$ 0$ & $\$ 0$ & $\$ 0$ & $\$ 0$ & $\$ 0$ \\
\hline 30 & $-\$ 309$ & $-\$ 793$ & $-\$ 574$ & $-\$ 886$ & $-\$ 776$ & $\$ 4,187$ & $\$ 4,187$ & $\$ 4,187$ & $\$ 4,187$ & $\$ 4,187$ \\
\hline
\end{tabular}




\begin{tabular}{|c|c|c|c|c|c|c|c|c|c|c|}
\hline \multirow[t]{2}{*}{ Standalone Retail } & \multicolumn{5}{|c|}{ Envelope, Power and Other } & \multicolumn{5}{|c|}{ Total } \\
\hline & $\begin{array}{c}2 \mathrm{~A} \\
\text { Houston } \\
\end{array}$ & $\begin{array}{c}\text { 3A } \\
\text { Memphis } \\
\end{array}$ & $\begin{array}{c}\text { 3B } \\
\text { El Paso } \\
\end{array}$ & $\begin{array}{c}4 \mathrm{~A} \\
\text { Baltimore } \\
\end{array}$ & $\begin{array}{c}5 \mathrm{~A} \\
\text { Chicago } \\
\end{array}$ & $\begin{array}{c}2 \mathrm{~A} \\
\text { Houston } \\
\end{array}$ & $\begin{array}{c}\text { 3A } \\
\text { Memphis } \\
\end{array}$ & $\begin{array}{c}3 \mathrm{~B} \\
\text { El Paso } \\
\end{array}$ & $\begin{array}{c}4 \mathrm{~A} \\
\text { Baltimore } \\
\end{array}$ & $\begin{array}{c}5 \mathrm{~A} \\
\text { Chicago } \\
\end{array}$ \\
\hline New Construction & $\$ 26,019$ & $\$ 26,019$ & $\$ 26,019$ & $\$ 26,019$ & $\$ 26,019$ & $\$ 52,140$ & $\$ 62,041$ & $\$ 38,255$ & $\$ 69,601$ & $\$ 49,333$ \\
\hline Maintenance & $\$ 0$ & $\$ 0$ & $\$ 0$ & $\$ 0$ & $\$ 0$ & $\$ 742$ & $\$ 767$ & $\$ 154$ & $\$ 758$ & $\$ 465$ \\
\hline Replacement (Year) & & & & & & $\$ 0$ & $\$ 0$ & $\$ 0$ & $\$ 0$ & $\$ 0$ \\
\hline 1 & $\$ 0$ & $\$ 0$ & $\$ 0$ & $\$ 0$ & $\$ 0$ & $\$ 0$ & $\$ 0$ & $\$ 0$ & $\$ 0$ & $\$ 0$ \\
\hline 2 & $\$ 0$ & $\$ 0$ & $\$ 0$ & $\$ 0$ & $\$ 0$ & $\$ 0$ & $\$ 0$ & $\$ 0$ & $\$ 0$ & $\$ 0$ \\
\hline 3 & $\$ 0$ & $\$ 0$ & $\$ 0$ & $\$ 0$ & $\$ 0$ & $-\$ 325$ & $-\$ 325$ & $-\$ 325$ & $-\$ 325$ & $-\$ 325$ \\
\hline 4 & $\$ 0$ & $\$ 0$ & $\$ 0$ & $\$ 0$ & $\$ 0$ & $-\$ 1,007$ & $-\$ 1,007$ & $-\$ 1,007$ & $-\$ 1,007$ & $-\$ 1,007$ \\
\hline 5 & $\$ 0$ & $\$ 0$ & $\$ 0$ & $\$ 0$ & $\$ 0$ & $-\$ 941$ & $-\$ 941$ & $-\$ 941$ & $-\$ 941$ & $-\$ 941$ \\
\hline 6 & $\$ 0$ & $\$ 0$ & $\$ 0$ & $\$ 0$ & $\$ 0$ & $-\$ 358$ & $-\$ 358$ & $-\$ 358$ & $-\$ 358$ & $-\$ 358$ \\
\hline 7 & $\$ 0$ & $\$ 0$ & $\$ 0$ & $\$ 0$ & $\$ 0$ & $\$ 551$ & $\$ 551$ & $\$ 551$ & $\$ 551$ & $\$ 551$ \\
\hline 8 & $\$ 0$ & $\$ 0$ & $\$ 0$ & $\$ 0$ & $\$ 0$ & $-\$ 1,007$ & $-\$ 1,007$ & $-\$ 1,007$ & $-\$ 1,007$ & $-\$ 1,007$ \\
\hline 9 & $\$ 0$ & $\$ 0$ & $\$ 0$ & $\$ 0$ & $\$ 0$ & $-\$ 408$ & $-\$ 408$ & $-\$ 408$ & $-\$ 408$ & $-\$ 408$ \\
\hline 10 & $\$ 0$ & $\$ 0$ & $\$ 0$ & $\$ 0$ & $\$ 0$ & $-\$ 1,770$ & $-\$ 1,770$ & $-\$ 1,770$ & $-\$ 1,770$ & $-\$ 1,770$ \\
\hline 11 & $\$ 0$ & $\$ 0$ & $\$ 0$ & $\$ 0$ & $\$ 0$ & $-\$ 3,868$ & $-\$ 3,868$ & $-\$ 3,868$ & $-\$ 3,868$ & $-\$ 3,868$ \\
\hline 12 & $\$ 0$ & $\$ 0$ & $\$ 0$ & $\$ 0$ & $\$ 0$ & $-\$ 1,366$ & $-\$ 1,366$ & $-\$ 1,366$ & $-\$ 1,366$ & $-\$ 1,366$ \\
\hline 13 & $\$ 0$ & $\$ 0$ & $\$ 0$ & $\$ 0$ & $\$ 0$ & $\$ 0$ & $\$ 0$ & $\$ 0$ & $\$ 0$ & $\$ 0$ \\
\hline 14 & $\$ 0$ & $\$ 0$ & $\$ 0$ & $\$ 0$ & $\$ 0$ & $-\$ 4,385$ & $-\$ 4,385$ & $-\$ 4,385$ & $-\$ 4,385$ & $-\$ 4,385$ \\
\hline 15 & $\$ 0$ & $\$ 0$ & $\$ 0$ & $\$ 0$ & $\$ 0$ & $\$ 30,118$ & $\$ 34,449$ & $\$ 10,163$ & $\$ 32,255$ & $\$ 17,691$ \\
\hline 16 & $\$ 0$ & $\$ 0$ & $\$ 0$ & $\$ 0$ & $\$ 0$ & $-\$ 1,007$ & $-\$ 1,007$ & $-\$ 1,007$ & $-\$ 1,007$ & $-\$ 1,007$ \\
\hline 17 & $\$ 0$ & $\$ 0$ & $\$ 0$ & $\$ 0$ & $\$ 0$ & $\$ 0$ & $\$ 0$ & $\$ 0$ & $\$ 0$ & $\$ 0$ \\
\hline 18 & $\$ 0$ & $\$ 0$ & $\$ 0$ & $\$ 0$ & $\$ 0$ & $\$ 1,410$ & $\$ 2,863$ & $\$ 3,070$ & $\$ 3,143$ & $\$ 3,108$ \\
\hline 19 & $\$ 0$ & $\$ 0$ & $\$ 0$ & $\$ 0$ & $\$ 0$ & $\$ 0$ & $\$ 0$ & $\$ 0$ & $\$ 0$ & $\$ 0$ \\
\hline 20 & $-\$ 34$ & $-\$ 34$ & $-\$ 34$ & $-\$ 34$ & $-\$ 34$ & $-\$ 1,406$ & $-\$ 1,406$ & $-\$ 1,982$ & $-\$ 1,406$ & $-\$ 1,603$ \\
\hline 21 & $\$ 0$ & $\$ 0$ & $\$ 0$ & $\$ 0$ & $\$ 0$ & $\$ 226$ & $\$ 226$ & $\$ 226$ & $\$ 226$ & $\$ 226$ \\
\hline 22 & $\$ 0$ & $\$ 0$ & $\$ 0$ & $\$ 0$ & $\$ 0$ & $-\$ 3,868$ & $-\$ 3,868$ & $-\$ 3,868$ & $-\$ 3,868$ & $-\$ 3,868$ \\
\hline 23 & $\$ 0$ & $\$ 0$ & $\$ 0$ & $\$ 0$ & $\$ 0$ & $\$ 364$ & $\$ 364$ & $\$ 364$ & $\$ 364$ & $\$ 364$ \\
\hline 24 & $\$ 0$ & $\$ 0$ & $\$ 0$ & $\$ 0$ & $\$ 0$ & $-\$ 1,366$ & $-\$ 1,366$ & $-\$ 1,366$ & $-\$ 1,366$ & $-\$ 1,366$ \\
\hline 25 & $\$ 25,891$ & $\$ 25,891$ & $\$ 25,891$ & $\$ 25,891$ & $\$ 25,891$ & $\$ 24,950$ & $\$ 24,950$ & $\$ 24,950$ & $\$ 24,950$ & $\$ 24,950$ \\
\hline 26 & $\$ 0$ & $\$ 0$ & $\$ 0$ & $\$ 0$ & $\$ 0$ & $\$ 0$ & $\$ 0$ & $\$ 0$ & $\$ 0$ & $\$ 0$ \\
\hline 27 & $\$ 0$ & $\$ 0$ & $\$ 0$ & $\$ 0$ & $\$ 0$ & $-\$ 408$ & $-\$ 408$ & $-\$ 408$ & $-\$ 408$ & $-\$ 408$ \\
\hline 28 & $\$ 0$ & $\$ 0$ & $\$ 0$ & $\$ 0$ & $\$ 0$ & $-\$ 5,393$ & $-\$ 5,393$ & $-\$ 5,393$ & $-\$ 5,393$ & $-\$ 5,393$ \\
\hline 29 & $\$ 0$ & $\$ 0$ & $\$ 0$ & $\$ 0$ & $\$ 0$ & $\$ 0$ & $\$ 0$ & $\$ 0$ & $\$ 0$ & $\$ 0$ \\
\hline 30 & $-\$ 22,221$ & $-\$ 22,221$ & $-\$ 22,221$ & $-\$ 22,221$ & $-\$ 22,221$ & $-\$ 18,343$ & $-\$ 18,827$ & $-\$ 18,608$ & $-\$ 18,920$ & $-\$ 18,810$ \\
\hline
\end{tabular}




\section{B.4 Primary School Cost Summary}

\begin{tabular}{|c|c|c|c|c|c|c|c|c|c|c|}
\hline \multirow[t]{2}{*}{ Primary School } & \multicolumn{5}{|c|}{ HVAC } & \multicolumn{5}{|c|}{ Lighting } \\
\hline & $\begin{array}{c}2 \mathrm{~A} \\
\text { Houston }\end{array}$ & $\begin{array}{c}\text { 3A } \\
\text { Memphis }\end{array}$ & $\begin{array}{c}3 \mathrm{~B} \\
\text { El Paso } \\
\end{array}$ & $\begin{array}{c}4 \mathrm{~A} \\
\text { Baltimore }\end{array}$ & $\begin{array}{c}5 \mathrm{~A} \\
\text { Chicago } \\
\end{array}$ & $\begin{array}{c}2 \mathrm{~A} \\
\text { Houston }\end{array}$ & $\begin{array}{c}\text { 3A } \\
\text { Memphis }\end{array}$ & $\begin{array}{c}3 \mathrm{~B} \\
\text { El Paso } \\
\end{array}$ & $\begin{array}{c}4 \mathrm{~A} \\
\text { Baltimore }\end{array}$ & $\begin{array}{c}5 \mathrm{~A} \\
\text { Chicago } \\
\end{array}$ \\
\hline New Construction & $\$ 116,255$ & $\$ 131,491$ & $-\$ 2,294$ & $\$ 131,863$ & $\$ 88,208$ & $-\$ 19,759$ & $-\$ 19,759$ & $-\$ 19,759$ & $-\$ 19,759$ & $-\$ 19,759$ \\
\hline Maintenance & $\$ 2,325$ & $\$ 2,326$ & $\$ 1,322$ & $\$ 2,325$ & $\$ 975$ & $\$ 0$ & $\$ 0$ & $\$ 0$ & $\$ 0$ & $\$ 0$ \\
\hline Replacement (Year) & & & & & & & & & & \\
\hline 1 & $\$ 0$ & $\$ 0$ & $\$ 0$ & $\$ 0$ & $\$ 0$ & $\$ 0$ & $\$ 0$ & $\$ 0$ & $\$ 0$ & $\$ 0$ \\
\hline 2 & $\$ 0$ & $\$ 0$ & $\$ 0$ & $\$ 0$ & $\$ 0$ & $\$ 566$ & $\$ 566$ & $\$ 566$ & $\$ 566$ & $\$ 566$ \\
\hline 3 & $\$ 0$ & $\$ 0$ & $\$ 0$ & $\$ 0$ & $\$ 0$ & $-\$ 6,620$ & $-\$ 6,620$ & $-\$ 6,620$ & $-\$ 6,620$ & $-\$ 6,620$ \\
\hline 4 & $\$ 0$ & $\$ 0$ & $\$ 0$ & $\$ 0$ & $\$ 0$ & $\$ 3,408$ & $\$ 3,408$ & $\$ 3,408$ & $\$ 3,408$ & $\$ 3,408$ \\
\hline 5 & $\$ 0$ & $\$ 0$ & $\$ 0$ & $\$ 0$ & $\$ 0$ & $-\$ 1,396$ & $-\$ 1,396$ & $-\$ 1,396$ & $-\$ 1,396$ & $-\$ 1,396$ \\
\hline 6 & $\$ 0$ & $\$ 0$ & $\$ 0$ & $\$ 0$ & $\$ 0$ & $-\$ 6,054$ & $-\$ 6,054$ & $-\$ 6,054$ & $-\$ 6,054$ & $-\$ 6,054$ \\
\hline 7 & $\$ 0$ & $\$ 0$ & $\$ 0$ & $\$ 0$ & $\$ 0$ & $\$ 0$ & $\$ 0$ & $\$ 0$ & $\$ 0$ & $\$ 0$ \\
\hline 8 & $\$ 0$ & $\$ 0$ & $\$ 0$ & $\$ 0$ & $\$ 0$ & $\$ 3,408$ & $\$ 3,408$ & $\$ 3,408$ & $\$ 3,408$ & $\$ 3,408$ \\
\hline 9 & $\$ 0$ & $\$ 0$ & $\$ 0$ & $\$ 0$ & $\$ 0$ & $-\$ 9,074$ & $-\$ 9,074$ & $-\$ 9,074$ & $-\$ 9,074$ & $-\$ 9,074$ \\
\hline 10 & $\$ 0$ & $\$ 0$ & $\$ 0$ & $\$ 0$ & $\$ 0$ & $-\$ 8,027$ & $-\$ 8,027$ & $-\$ 8,027$ & $-\$ 8,027$ & $-\$ 8,027$ \\
\hline 11 & $\$ 0$ & $\$ 0$ & $\$ 0$ & $\$ 0$ & $\$ 0$ & $-\$ 2,914$ & $-\$ 2,914$ & $-\$ 2,914$ & $-\$ 2,914$ & $-\$ 2,914$ \\
\hline 12 & $\$ 0$ & $\$ 0$ & $\$ 0$ & $\$ 0$ & $\$ 0$ & $-\$ 3,212$ & $-\$ 3,212$ & $-\$ 3,212$ & $-\$ 3,212$ & $-\$ 3,212$ \\
\hline 13 & $\$ 0$ & $\$ 0$ & $\$ 0$ & $\$ 0$ & $\$ 0$ & $\$ 0$ & $\$ 0$ & $\$ 0$ & $\$ 0$ & $\$ 0$ \\
\hline 14 & $\$ 0$ & $\$ 0$ & $\$ 0$ & $\$ 0$ & $\$ 0$ & $-\$ 25,340$ & $-\$ 25,340$ & $-\$ 25,340$ & $-\$ 25,340$ & $-\$ 25,340$ \\
\hline 15 & $\$ 152,380$ & $\$ 159,356$ & $\$ 14,872$ & $\$ 164,786$ & $\$ 118,108$ & $\$ 62,133$ & $\$ 62,133$ & $\$ 62,133$ & $\$ 62,133$ & $\$ 62,133$ \\
\hline 16 & $\$ 0$ & $\$ 0$ & $\$ 0$ & $\$ 0$ & $\$ 0$ & $\$ 3,408$ & $\$ 3,408$ & $\$ 3,408$ & $\$ 3,408$ & $\$ 3,408$ \\
\hline 17 & $\$ 0$ & $\$ 0$ & $\$ 0$ & $\$ 0$ & $\$ 0$ & $\$ 0$ & $\$ 0$ & $\$ 0$ & $\$ 0$ & $\$ 0$ \\
\hline 18 & $-\$ 1,369$ & $-\$ 178$ & $-\$ 824$ & $\$ 16$ & $\$ 330$ & $-\$ 6,322$ & $-\$ 6,322$ & $-\$ 6,322$ & $-\$ 6,322$ & $-\$ 6,322$ \\
\hline 19 & $\$ 0$ & $\$ 0$ & $\$ 0$ & $\$ 0$ & $\$ 0$ & $\$ 0$ & $\$ 0$ & $\$ 0$ & $\$ 0$ & $\$ 0$ \\
\hline 20 & $\$ 2,982$ & $\$ 3,199$ & $\$ 2,926$ & $\$ 3,071$ & $-\$ 98$ & $-\$ 5,186$ & $-\$ 5,186$ & $-\$ 5,186$ & $-\$ 5,186$ & $-\$ 5,186$ \\
\hline 21 & $\$ 0$ & $\$ 0$ & $\$ 0$ & $\$ 0$ & $\$ 0$ & $-\$ 6,620$ & $-\$ 6,620$ & $-\$ 6,620$ & $-\$ 6,620$ & $-\$ 6,620$ \\
\hline 22 & $\$ 0$ & $\$ 0$ & $\$ 0$ & $\$ 0$ & $\$ 0$ & $-\$ 2,348$ & $-\$ 2,348$ & $-\$ 2,348$ & $-\$ 2,348$ & $-\$ 2,348$ \\
\hline 23 & $\$ 0$ & $\$ 0$ & $\$ 0$ & $\$ 0$ & $\$ 0$ & $\$ 0$ & $\$ 0$ & $\$ 0$ & $\$ 0$ & $\$ 0$ \\
\hline 24 & $\$ 0$ & $\$ 0$ & $\$ 0$ & $\$ 0$ & $\$ 0$ & $-\$ 3,212$ & $-\$ 3,212$ & $-\$ 3,212$ & $-\$ 3,212$ & $-\$ 3,212$ \\
\hline 25 & $-\$ 539$ & $-\$ 539$ & $-\$ 539$ & $-\$ 539$ & $-\$ 539$ & $-\$ 1,396$ & $-\$ 1,396$ & $-\$ 1,396$ & $-\$ 1,396$ & $-\$ 1,396$ \\
\hline 26 & $\$ 0$ & $\$ 0$ & $\$ 0$ & $\$ 0$ & $\$ 0$ & $\$ 566$ & $\$ 566$ & $\$ 566$ & $\$ 566$ & $\$ 566$ \\
\hline 27 & $\$ 0$ & $\$ 0$ & $\$ 0$ & $\$ 0$ & $\$ 0$ & $-\$ 9,074$ & $-\$ 9,074$ & $-\$ 9,074$ & $-\$ 9,074$ & $-\$ 9,074$ \\
\hline 28 & $\$ 0$ & $\$ 0$ & $\$ 0$ & $\$ 0$ & $\$ 0$ & $-\$ 22,499$ & $-\$ 22,499$ & $-\$ 22,499$ & $-\$ 22,499$ & $-\$ 22,499$ \\
\hline 29 & $\$ 0$ & $\$ 0$ & $\$ 0$ & $\$ 0$ & $\$ 0$ & $\$ 0$ & $\$ 0$ & $\$ 0$ & $\$ 0$ & $\$ 0$ \\
\hline 30 & $\$ 127$ & $-\$ 1,248$ & $\$ 218$ & $-\$ 552$ & $\$ 760$ & $\$ 22,486$ & $\$ 22,486$ & $\$ 22,486$ & $\$ 22,486$ & $\$ 22,486$ \\
\hline
\end{tabular}




\begin{tabular}{|c|c|c|c|c|c|c|c|c|c|c|}
\hline \multirow[t]{2}{*}{ Primary School } & \multicolumn{5}{|c|}{ Envelope, Power and Other } & \multicolumn{5}{|c|}{ Total } \\
\hline & $\begin{array}{c}2 \mathrm{~A} \\
\text { Houston } \\
\end{array}$ & $\begin{array}{c}\text { 3A } \\
\text { Memphis } \\
\end{array}$ & $\begin{array}{c}\text { 3B } \\
\text { El Paso } \\
\end{array}$ & $\begin{array}{c}4 \mathrm{~A} \\
\text { Baltimore } \\
\end{array}$ & $\begin{array}{c}5 \mathrm{~A} \\
\text { Chicago } \\
\end{array}$ & $\begin{array}{c}2 \mathrm{~A} \\
\text { Houston } \\
\end{array}$ & $\begin{array}{c}\text { 3A } \\
\text { Memphis } \\
\end{array}$ & $\begin{array}{c}\text { 3B } \\
\text { El Paso } \\
\end{array}$ & $\begin{array}{c}4 \mathrm{~A} \\
\text { Baltimore } \\
\end{array}$ & $\begin{array}{c}5 \mathrm{~A} \\
\text { Chicago } \\
\end{array}$ \\
\hline New Construction & $\$ 37,664$ & $\$ 37,664$ & $\$ 37,664$ & $\$ 37,664$ & $\$ 37,664$ & $\$ 134,160$ & $\$ 149,396$ & $\$ 15,611$ & $\$ 149,768$ & $\$ 106,113$ \\
\hline Maintenance & $\$ 0$ & $\$ 0$ & $\$ 0$ & $\$ 0$ & $\$ 0$ & $\$ 2,325$ & $\$ 2,326$ & $\$ 1,322$ & $\$ 2,325$ & $\$ 975$ \\
\hline Replacement (Year) & & & & & & $\$ 0$ & $\$ 0$ & $\$ 0$ & $\$ 0$ & $\$ 0$ \\
\hline 1 & $\$ 0$ & $\$ 0$ & $\$ 0$ & $\$ 0$ & $\$ 0$ & $\$ 0$ & $\$ 0$ & $\$ 0$ & $\$ 0$ & $\$ 0$ \\
\hline 2 & $\$ 0$ & $\$ 0$ & $\$ 0$ & $\$ 0$ & $\$ 0$ & $\$ 566$ & $\$ 566$ & $\$ 566$ & $\$ 566$ & $\$ 566$ \\
\hline 3 & $\$ 0$ & $\$ 0$ & $\$ 0$ & $\$ 0$ & $\$ 0$ & $-\$ 6,620$ & $-\$ 6,620$ & $-\$ 6,620$ & $-\$ 6,620$ & $-\$ 6,620$ \\
\hline 4 & $\$ 0$ & $\$ 0$ & $\$ 0$ & $\$ 0$ & $\$ 0$ & $\$ 3,408$ & $\$ 3,408$ & $\$ 3,408$ & $\$ 3,408$ & $\$ 3,408$ \\
\hline 5 & $\$ 0$ & $\$ 0$ & $\$ 0$ & $\$ 0$ & $\$ 0$ & $-\$ 1,396$ & $-\$ 1,396$ & $-\$ 1,396$ & $-\$ 1,396$ & $-\$ 1,396$ \\
\hline 6 & $\$ 0$ & $\$ 0$ & $\$ 0$ & $\$ 0$ & $\$ 0$ & $-\$ 6,054$ & $-\$ 6,054$ & $-\$ 6,054$ & $-\$ 6,054$ & $-\$ 6,054$ \\
\hline 7 & $\$ 0$ & $\$ 0$ & $\$ 0$ & $\$ 0$ & $\$ 0$ & $\$ 0$ & $\$ 0$ & $\$ 0$ & $\$ 0$ & $\$ 0$ \\
\hline 8 & $\$ 0$ & $\$ 0$ & $\$ 0$ & $\$ 0$ & $\$ 0$ & $\$ 3,408$ & $\$ 3,408$ & $\$ 3,408$ & $\$ 3,408$ & $\$ 3,408$ \\
\hline 9 & $\$ 0$ & $\$ 0$ & $\$ 0$ & $\$ 0$ & $\$ 0$ & $-\$ 9,074$ & $-\$ 9,074$ & $-\$ 9,074$ & $-\$ 9,074$ & $-\$ 9,074$ \\
\hline 10 & $\$ 0$ & $\$ 0$ & $\$ 0$ & $\$ 0$ & $\$ 0$ & $-\$ 8,027$ & $-\$ 8,027$ & $-\$ 8,027$ & $-\$ 8,027$ & $-\$ 8,027$ \\
\hline 11 & $\$ 0$ & $\$ 0$ & $\$ 0$ & $\$ 0$ & $\$ 0$ & $-\$ 2,914$ & $-\$ 2,914$ & $-\$ 2,914$ & $-\$ 2,914$ & $-\$ 2,914$ \\
\hline 12 & $\$ 0$ & $\$ 0$ & $\$ 0$ & $\$ 0$ & $\$ 0$ & $-\$ 3,212$ & $-\$ 3,212$ & $-\$ 3,212$ & $-\$ 3,212$ & $-\$ 3,212$ \\
\hline 13 & $\$ 0$ & $\$ 0$ & $\$ 0$ & $\$ 0$ & $\$ 0$ & $\$ 0$ & $\$ 0$ & $\$ 0$ & $\$ 0$ & $\$ 0$ \\
\hline 14 & $\$ 0$ & $\$ 0$ & $\$ 0$ & $\$ 0$ & $\$ 0$ & $-\$ 25,340$ & $-\$ 25,340$ & $-\$ 25,340$ & $-\$ 25,340$ & $-\$ 25,340$ \\
\hline 15 & $\$ 0$ & $\$ 0$ & $\$ 0$ & $\$ 0$ & $\$ 0$ & $\$ 214,513$ & $\$ 221,489$ & $\$ 77,005$ & $\$ 226,919$ & $\$ 180,241$ \\
\hline 16 & $\$ 0$ & $\$ 0$ & $\$ 0$ & $\$ 0$ & $\$ 0$ & $\$ 3,408$ & $\$ 3,408$ & $\$ 3,408$ & $\$ 3,408$ & $\$ 3,408$ \\
\hline 17 & $\$ 0$ & $\$ 0$ & $\$ 0$ & $\$ 0$ & $\$ 0$ & $\$ 0$ & $\$ 0$ & $\$ 0$ & $\$ 0$ & $\$ 0$ \\
\hline 18 & $\$ 0$ & $\$ 0$ & $\$ 0$ & $\$ 0$ & $\$ 0$ & $-\$ 7,691$ & $-\$ 6,499$ & $-\$ 7,146$ & $-\$ 6,305$ & $-\$ 5,992$ \\
\hline 19 & $\$ 0$ & $\$ 0$ & $\$ 0$ & $\$ 0$ & $\$ 0$ & $\$ 0$ & $\$ 0$ & $\$ 0$ & $\$ 0$ & $\$ 0$ \\
\hline 20 & $-\$ 1,509$ & $-\$ 1,509$ & $-\$ 1,509$ & $-\$ 1,509$ & $-\$ 1,509$ & $-\$ 3,713$ & $-\$ 3,496$ & $-\$ 3,768$ & $-\$ 3,624$ & $-\$ 6,793$ \\
\hline 21 & $\$ 0$ & $\$ 0$ & $\$ 0$ & $\$ 0$ & $\$ 0$ & $-\$ 6,620$ & $-\$ 6,620$ & $-\$ 6,620$ & $-\$ 6,620$ & $-\$ 6,620$ \\
\hline 22 & $\$ 0$ & $\$ 0$ & $\$ 0$ & $\$ 0$ & $\$ 0$ & $-\$ 2,348$ & $-\$ 2,348$ & $-\$ 2,348$ & $-\$ 2,348$ & $-\$ 2,348$ \\
\hline 23 & $\$ 0$ & $\$ 0$ & $\$ 0$ & $\$ 0$ & $\$ 0$ & $\$ 0$ & $\$ 0$ & $\$ 0$ & $\$ 0$ & $\$ 0$ \\
\hline 24 & $\$ 0$ & $\$ 0$ & $\$ 0$ & $\$ 0$ & $\$ 0$ & $-\$ 3,212$ & $-\$ 3,212$ & $-\$ 3,212$ & $-\$ 3,212$ & $-\$ 3,212$ \\
\hline 25 & $\$ 0$ & $\$ 0$ & $\$ 0$ & $\$ 0$ & $\$ 0$ & $-\$ 1,935$ & $-\$ 1,935$ & $-\$ 1,935$ & $-\$ 1,935$ & $-\$ 1,935$ \\
\hline 26 & $\$ 0$ & $\$ 0$ & $\$ 0$ & $\$ 0$ & $\$ 0$ & $\$ 566$ & $\$ 566$ & $\$ 566$ & $\$ 566$ & $\$ 566$ \\
\hline 27 & $\$ 0$ & $\$ 0$ & $\$ 0$ & $\$ 0$ & $\$ 0$ & $-\$ 9,074$ & $-\$ 9,074$ & $-\$ 9,074$ & $-\$ 9,074$ & $-\$ 9,074$ \\
\hline 28 & $\$ 0$ & $\$ 0$ & $\$ 0$ & $\$ 0$ & $\$ 0$ & $-\$ 22,499$ & $-\$ 22,499$ & $-\$ 22,499$ & $-\$ 22,499$ & $-\$ 22,499$ \\
\hline 29 & $\$ 0$ & $\$ 0$ & $\$ 0$ & $\$ 0$ & $\$ 0$ & $\$ 0$ & $\$ 0$ & $\$ 0$ & $\$ 0$ & $\$ 0$ \\
\hline 30 & $-\$ 3,955$ & $-\$ 3,955$ & $-\$ 3,955$ & $-\$ 3,955$ & $-\$ 3,955$ & $\$ 18,658$ & $\$ 17,283$ & $\$ 18,749$ & $\$ 17,979$ & $\$ 19,292$ \\
\hline
\end{tabular}




\section{B.5 Small Hotel Cost Summary}

\begin{tabular}{|c|c|c|c|c|c|c|c|c|c|c|}
\hline \multirow[t]{2}{*}{ Small Hotel } & \multicolumn{4}{|c|}{ HVAC } & \multicolumn{4}{|c|}{ Total } & \multirow[b]{2}{*}{$\begin{array}{c}\text { 4A } \\
\text { Baltimore }\end{array}$} & \multirow[b]{2}{*}{$\begin{array}{c}\text { 5A } \\
\text { Chicago }\end{array}$} \\
\hline & $\begin{array}{c}2 \mathrm{~A} \\
\text { Houston }\end{array}$ & $\begin{array}{c}\text { 3A } \\
\text { Memphis }\end{array}$ & $\begin{array}{c}\text { 3B } \\
\text { El Paso }\end{array}$ & $\begin{array}{c}\text { 4A } \\
\text { Baltimore }\end{array}$ & $\begin{array}{c}5 \mathrm{~A} \\
\text { Chicago }\end{array}$ & $\begin{array}{c}2 \mathrm{~A} \\
\text { Houston }\end{array}$ & $\begin{array}{c}\text { 3A } \\
\text { Memphis }\end{array}$ & $\begin{array}{c}\text { 3B } \\
\text { El Paso }\end{array}$ & & \\
\hline New Construction & $\$ 925$ & $-\$ 9,110$ & $-\$ 4,678$ & $\$ 2,574$ & $-\$ 12,763$ & $-\$ 11,597$ & $-\$ 11,597$ & $-\$ 11,597$ & $-\$ 11,597$ & $-\$ 11,597$ \\
\hline Maintenance & $\$ 607$ & $-\$ 10$ & $-\$ 8$ & $\$ 604$ & $-\$ 16$ & $\$ 0$ & $\$ 0$ & $\$ 0$ & $\$ 0$ & $\$ 0$ \\
\hline \multicolumn{11}{|l|}{ Replacement (Year) } \\
\hline 1 & $\$ 0$ & $\$ 0$ & $\$ 0$ & $\$ 0$ & $\$ 0$ & $-\$ 693$ & $-\$ 693$ & $-\$ 693$ & $-\$ 693$ & $-\$ 693$ \\
\hline 2 & $\$ 0$ & $\$ 0$ & $\$ 0$ & $\$ 0$ & $\$ 0$ & $-\$ 696$ & $-\$ 696$ & $-\$ 696$ & $-\$ 696$ & $-\$ 696$ \\
\hline 3 & $\$ 0$ & $\$ 0$ & $\$ 0$ & $\$ 0$ & $\$ 0$ & $-\$ 30,759$ & $-\$ 30,759$ & $-\$ 30,759$ & $-\$ 30,759$ & $-\$ 30,759$ \\
\hline 4 & $\$ 0$ & $\$ 0$ & $\$ 0$ & $\$ 0$ & $\$ 0$ & $-\$ 4,647$ & $-\$ 4,647$ & $-\$ 4,647$ & $-\$ 4,647$ & $-\$ 4,647$ \\
\hline 5 & $\$ 0$ & $\$ 0$ & $\$ 0$ & $\$ 0$ & $\$ 0$ & $-\$ 1,734$ & $-\$ 1,734$ & $-\$ 1,734$ & $-\$ 1,734$ & $-\$ 1,734$ \\
\hline 6 & $\$ 0$ & $\$ 0$ & $\$ 0$ & $\$ 0$ & $\$ 0$ & $-\$ 32,264$ & $-\$ 32,264$ & $-\$ 32,264$ & $-\$ 32,264$ & $-\$ 32,264$ \\
\hline 7 & $\$ 0$ & $\$ 0$ & $\$ 0$ & $\$ 0$ & $\$ 0$ & $-\$ 693$ & $-\$ 693$ & $-\$ 693$ & $-\$ 693$ & $-\$ 693$ \\
\hline 8 & $\$ 0$ & $\$ 0$ & $\$ 0$ & $\$ 0$ & $\$ 0$ & $-\$ 5,465$ & $-\$ 5,465$ & $-\$ 5,465$ & $-\$ 5,465$ & $-\$ 5,465$ \\
\hline 9 & $\$ 0$ & $\$ 0$ & $\$ 0$ & $\$ 0$ & $\$ 0$ & $-\$ 30,879$ & $-\$ 30,879$ & $-\$ 30,879$ & $-\$ 30,879$ & $-\$ 30,879$ \\
\hline 10 & $\$ 0$ & $\$ 0$ & $\$ 0$ & $\$ 0$ & $\$ 0$ & $\$ 7,986$ & $\$ 7,986$ & $\$ 7,986$ & $\$ 7,986$ & $\$ 7,986$ \\
\hline 11 & $\$ 0$ & $\$ 0$ & $\$ 0$ & $\$ 0$ & $\$ 0$ & $-\$ 7,790$ & $-\$ 7,790$ & $-\$ 7,790$ & $-\$ 7,790$ & $-\$ 7,790$ \\
\hline 12 & $\$ 0$ & $\$ 0$ & $\$ 0$ & $\$ 0$ & $\$ 0$ & $-\$ 36,215$ & $-\$ 36,215$ & $-\$ 36,215$ & $-\$ 36,215$ & $-\$ 36,215$ \\
\hline 13 & $\$ 0$ & $\$ 0$ & $\$ 0$ & $\$ 0$ & $\$ 0$ & $-\$ 693$ & $-\$ 693$ & $-\$ 693$ & $-\$ 693$ & $-\$ 693$ \\
\hline 14 & $\$ 0$ & $\$ 0$ & $\$ 0$ & $\$ 0$ & $\$ 0$ & $\$ 142$ & $\$ 142$ & $\$ 142$ & $\$ 142$ & $\$ 142$ \\
\hline 15 & $\$ 6,439$ & $-\$ 4,147$ & $-\$ 45$ & $\$ 8,330$ & $-\$ 7,317$ & $-\$ 10,884$ & $-\$ 10,884$ & $-\$ 10,884$ & $-\$ 10,884$ & $-\$ 10,884$ \\
\hline 16 & $\$ 0$ & $\$ 0$ & $\$ 0$ & $\$ 0$ & $\$ 0$ & $-\$ 5,465$ & $-\$ 5,465$ & $-\$ 5,465$ & $-\$ 5,465$ & $-\$ 5,465$ \\
\hline 17 & $\$ 0$ & $\$ 0$ & $\$ 0$ & $\$ 0$ & $\$ 0$ & $-\$ 2,632$ & $-\$ 2,632$ & $-\$ 2,632$ & $-\$ 2,632$ & $-\$ 2,632$ \\
\hline 18 & $-\$ 9$ & $-\$ 9$ & $-\$ 9$ & $-\$ 9$ & $-\$ 9$ & $-\$ 27,637$ & $-\$ 27,637$ & $-\$ 27,637$ & $-\$ 27,637$ & $-\$ 27,637$ \\
\hline 19 & $\$ 0$ & $\$ 0$ & $\$ 0$ & $\$ 0$ & $\$ 0$ & $-\$ 693$ & $-\$ 693$ & $-\$ 693$ & $-\$ 693$ & $-\$ 693$ \\
\hline 20 & $\$ 1,895$ & $\$ 0$ & $\$ 0$ & $\$ 1,895$ & $\$ 0$ & $\$ 4,036$ & $\$ 4,036$ & $\$ 4,036$ & $\$ 4,036$ & $\$ 4,036$ \\
\hline 21 & $\$ 0$ & $\$ 0$ & $\$ 0$ & $\$ 0$ & $\$ 0$ & $-\$ 30,759$ & $-\$ 30,759$ & $-\$ 30,759$ & $-\$ 30,759$ & $-\$ 30,759$ \\
\hline 22 & $\$ 0$ & $\$ 0$ & $\$ 0$ & $\$ 0$ & $\$ 0$ & $-\$ 7,793$ & $-\$ 7,793$ & $-\$ 7,793$ & $-\$ 7,793$ & $-\$ 7,793$ \\
\hline 23 & $\$ 0$ & $\$ 0$ & $\$ 0$ & $\$ 0$ & $\$ 0$ & $\$ 477$ & $\$ 477$ & $\$ 477$ & $\$ 477$ & $\$ 477$ \\
\hline 24 & $\$ 0$ & $\$ 0$ & $\$ 0$ & $\$ 0$ & $\$ 0$ & $-\$ 37,033$ & $-\$ 37,033$ & $-\$ 37,033$ & $-\$ 37,033$ & $-\$ 37,033$ \\
\hline 25 & $\$ 0$ & $\$ 0$ & $\$ 0$ & $\$ 0$ & $\$ 0$ & $-\$ 1,734$ & $-\$ 1,734$ & $-\$ 1,734$ & $-\$ 1,734$ & $-\$ 1,734$ \\
\hline 26 & $\$ 0$ & $\$ 0$ & $\$ 0$ & $\$ 0$ & $\$ 0$ & $-\$ 696$ & $-\$ 696$ & $-\$ 696$ & $-\$ 696$ & $-\$ 696$ \\
\hline 27 & $\$ 0$ & $\$ 0$ & $\$ 0$ & $\$ 0$ & $\$ 0$ & $-\$ 30,879$ & $-\$ 30,879$ & $-\$ 30,879$ & $-\$ 30,879$ & $-\$ 30,879$ \\
\hline 28 & $\$ 0$ & $\$ 0$ & $\$ 0$ & $\$ 0$ & $\$ 0$ & $-\$ 3,809$ & $-\$ 3,809$ & $-\$ 3,809$ & $-\$ 3,809$ & $-\$ 3,809$ \\
\hline 29 & $\$ 0$ & $\$ 0$ & $\$ 0$ & $\$ 0$ & $\$ 0$ & $-\$ 693$ & $-\$ 693$ & $-\$ 693$ & $-\$ 693$ & $-\$ 693$ \\
\hline 30 & $-\$ 944$ & $\$ 3$ & $\$ 3$ & $-\$ 944$ & $\$ 3$ & $\$ 1,538$ & $\$ 1,538$ & $\$ 1,538$ & $\$ 1,538$ & $\$ 1,538$ \\
\hline
\end{tabular}




\begin{tabular}{|c|c|c|c|c|c|c|c|c|c|c|}
\hline Small Hotel & Envelope, Powe & nd Other & & & & & Total & & & \\
\hline & $\begin{array}{c}2 \mathrm{~A} \\
\text { Houston }\end{array}$ & $\begin{array}{c}\text { 3A } \\
\text { Memphis }\end{array}$ & $\begin{array}{c}\text { 3B } \\
\text { El Paso }\end{array}$ & $\begin{array}{c}\text { 4A } \\
\text { Baltimore }\end{array}$ & $\begin{array}{c}5 \mathrm{~A} \\
\text { Chicago }\end{array}$ & $\begin{array}{c}2 \mathrm{~A} \\
\text { Houston }\end{array}$ & $\begin{array}{c}\text { 3A } \\
\text { Memphis }\end{array}$ & $\begin{array}{c}\text { 3B } \\
\text { El Paso }\end{array}$ & $\begin{array}{c}4 \mathrm{~A} \\
\text { Baltimore }\end{array}$ & $\begin{array}{c}5 \mathrm{~A} \\
\text { Chicago }\end{array}$ \\
\hline New Construction & $\$ 15,594$ & $\$ 15,594$ & $\$ 15,594$ & $\$ 15,594$ & $\$ 15,594$ & $\$ 4,922$ & $-\$ 5,113$ & $-\$ 681$ & $\$ 6,571$ & $-\$ 8,766$ \\
\hline Maintenance & $\$ 0$ & $\$ 0$ & $\$ 0$ & $\$ 0$ & $\$ 0$ & $\$ 607$ & $-\$ 10$ & $-\$ 8$ & $\$ 604$ & $-\$ 16$ \\
\hline Replacement (Year) & & & & & & $\$ 0$ & $\$ 0$ & $\$ 0$ & $\$ 0$ & $\$ 0$ \\
\hline 1 & $-\$ 657$ & $-\$ 657$ & $-\$ 657$ & $-\$ 657$ & $-\$ 657$ & $-\$ 1,350$ & $-\$ 1,350$ & $-\$ 1,350$ & $-\$ 1,350$ & $-\$ 1,350$ \\
\hline 2 & $-\$ 657$ & $-\$ 657$ & $-\$ 657$ & $-\$ 657$ & $-\$ 657$ & $-\$ 1,353$ & $-\$ 1,353$ & $-\$ 1,353$ & $-\$ 1,353$ & $-\$ 1,353$ \\
\hline 3 & $-\$ 657$ & $-\$ 657$ & $-\$ 657$ & $-\$ 657$ & $-\$ 657$ & $-\$ 31,416$ & $-\$ 31,416$ & $-\$ 31,416$ & $-\$ 31,416$ & $-\$ 31,416$ \\
\hline 4 & $-\$ 657$ & $-\$ 657$ & $-\$ 657$ & $-\$ 657$ & $-\$ 657$ & $-\$ 5,304$ & $-\$ 5,304$ & $-\$ 5,304$ & $-\$ 5,304$ & $-\$ 5,304$ \\
\hline 5 & $-\$ 880$ & $-\$ 880$ & $-\$ 880$ & $-\$ 880$ & $-\$ 880$ & $-\$ 2,614$ & $-\$ 2,614$ & $-\$ 2,614$ & $-\$ 2,614$ & $-\$ 2,614$ \\
\hline 6 & $-\$ 657$ & $-\$ 657$ & $-\$ 657$ & $-\$ 657$ & $-\$ 657$ & $-\$ 32,921$ & $-\$ 32,921$ & $-\$ 32,921$ & $-\$ 32,921$ & $-\$ 32,921$ \\
\hline 7 & $-\$ 657$ & $-\$ 657$ & $-\$ 657$ & $-\$ 657$ & $-\$ 657$ & $-\$ 1,350$ & $-\$ 1,350$ & $-\$ 1,350$ & $-\$ 1,350$ & $-\$ 1,350$ \\
\hline 8 & $-\$ 657$ & $-\$ 657$ & $-\$ 657$ & $-\$ 657$ & $-\$ 657$ & $-\$ 6,122$ & $-\$ 6,122$ & $-\$ 6,122$ & $-\$ 6,122$ & $-\$ 6,122$ \\
\hline 9 & $-\$ 657$ & $-\$ 657$ & $-\$ 657$ & $-\$ 657$ & $-\$ 657$ & $-\$ 31,536$ & $-\$ 31,536$ & $-\$ 31,536$ & $-\$ 31,536$ & $-\$ 31,536$ \\
\hline 10 & $-\$ 880$ & $-\$ 880$ & $-\$ 880$ & $-\$ 880$ & $-\$ 880$ & $\$ 7,107$ & $\$ 7,107$ & $\$ 7,107$ & $\$ 7,107$ & $\$ 7,107$ \\
\hline 11 & $-\$ 657$ & $-\$ 657$ & $-\$ 657$ & $-\$ 657$ & $-\$ 657$ & $-\$ 8,447$ & $-\$ 8,447$ & $-\$ 8,447$ & $-\$ 8,447$ & $-\$ 8,447$ \\
\hline 12 & $-\$ 657$ & $-\$ 657$ & $-\$ 657$ & $-\$ 657$ & $-\$ 657$ & $-\$ 36,872$ & $-\$ 36,872$ & $-\$ 36,872$ & $-\$ 36,872$ & $-\$ 36,872$ \\
\hline 13 & $-\$ 657$ & $-\$ 657$ & $-\$ 657$ & $-\$ 657$ & $-\$ 657$ & $-\$ 1,350$ & $-\$ 1,350$ & $-\$ 1,350$ & $-\$ 1,350$ & $-\$ 1,350$ \\
\hline 14 & $-\$ 657$ & $-\$ 657$ & $-\$ 657$ & $-\$ 657$ & $-\$ 657$ & $-\$ 515$ & $-\$ 515$ & $-\$ 515$ & $-\$ 515$ & $-\$ 515$ \\
\hline 15 & $-\$ 880$ & $-\$ 880$ & $-\$ 880$ & $-\$ 880$ & $-\$ 880$ & $-\$ 5,325$ & $-\$ 15,912$ & $-\$ 11,809$ & $-\$ 3,434$ & $-\$ 19,081$ \\
\hline 16 & $-\$ 657$ & $-\$ 657$ & $-\$ 657$ & $-\$ 657$ & $-\$ 657$ & $-\$ 6,122$ & $-\$ 6,122$ & $-\$ 6,122$ & $-\$ 6,122$ & $-\$ 6,122$ \\
\hline 17 & $-\$ 657$ & $-\$ 657$ & $-\$ 657$ & $-\$ 657$ & $-\$ 657$ & $-\$ 3,289$ & $-\$ 3,289$ & $-\$ 3,289$ & $-\$ 3,289$ & $-\$ 3,289$ \\
\hline 18 & $-\$ 657$ & $-\$ 657$ & $-\$ 657$ & $-\$ 657$ & $-\$ 657$ & $-\$ 28,304$ & $-\$ 28,304$ & $-\$ 28,304$ & $-\$ 28,304$ & $-\$ 28,304$ \\
\hline 19 & $-\$ 657$ & $-\$ 657$ & $-\$ 657$ & $-\$ 657$ & $-\$ 657$ & $-\$ 1,350$ & $-\$ 1,350$ & $-\$ 1,350$ & $-\$ 1,350$ & $-\$ 1,350$ \\
\hline 20 & $-\$ 1,014$ & $-\$ 1,014$ & $-\$ 1,014$ & $-\$ 1,014$ & $-\$ 1,014$ & $\$ 4,917$ & $\$ 3,022$ & $\$ 3,022$ & $\$ 4,917$ & $\$ 3,022$ \\
\hline 21 & $\$ 85$ & $\$ 85$ & $\$ 85$ & $\$ 85$ & $\$ 85$ & $-\$ 30,674$ & $-\$ 30,674$ & $-\$ 30,674$ & $-\$ 30,674$ & $-\$ 30,674$ \\
\hline 22 & $-\$ 657$ & $-\$ 657$ & $-\$ 657$ & $-\$ 657$ & $-\$ 657$ & $-\$ 8,450$ & $-\$ 8,450$ & $-\$ 8,450$ & $-\$ 8,450$ & $-\$ 8,450$ \\
\hline 23 & $-\$ 657$ & $-\$ 657$ & $-\$ 657$ & $-\$ 657$ & $-\$ 657$ & $-\$ 180$ & $-\$ 180$ & $-\$ 180$ & $-\$ 180$ & $-\$ 180$ \\
\hline 24 & $-\$ 657$ & $-\$ 657$ & $-\$ 657$ & $-\$ 657$ & $-\$ 657$ & $-\$ 37,690$ & $-\$ 37,690$ & $-\$ 37,690$ & $-\$ 37,690$ & $-\$ 37,690$ \\
\hline 25 & $-\$ 880$ & $-\$ 880$ & $-\$ 880$ & $-\$ 880$ & $-\$ 880$ & $-\$ 2,614$ & $-\$ 2,614$ & $-\$ 2,614$ & $-\$ 2,614$ & $-\$ 2,614$ \\
\hline 26 & $-\$ 657$ & $-\$ 657$ & $-\$ 657$ & $-\$ 657$ & $-\$ 657$ & $-\$ 1,353$ & $-\$ 1,353$ & $-\$ 1,353$ & $-\$ 1,353$ & $-\$ 1,353$ \\
\hline 27 & $-\$ 657$ & $-\$ 657$ & $-\$ 657$ & $-\$ 657$ & $-\$ 657$ & $-\$ 31,536$ & $-\$ 31,536$ & $-\$ 31,536$ & $-\$ 31,536$ & $-\$ 31,536$ \\
\hline 28 & $-\$ 657$ & $-\$ 657$ & $-\$ 657$ & $-\$ 657$ & $-\$ 657$ & $-\$ 4,466$ & $-\$ 4,466$ & $-\$ 4,466$ & $-\$ 4,466$ & $-\$ 4,466$ \\
\hline 29 & $-\$ 657$ & $-\$ 657$ & $-\$ 657$ & $-\$ 657$ & $-\$ 657$ & $-\$ 1,350$ & $-\$ 1,350$ & $-\$ 1,350$ & $-\$ 1,350$ & $-\$ 1,350$ \\
\hline 30 & $-\$ 3,091$ & $-\$ 3,091$ & $-\$ 3,091$ & $-\$ 3,091$ & $-\$ 3,091$ & $-\$ 2,498$ & $-\$ 1,551$ & $-\$ 1,551$ & $-\$ 2,498$ & $-\$ 1,551$ \\
\hline
\end{tabular}




\begin{tabular}{|c|c|c|c|c|c|c|c|c|c|c|}
\hline \multirow[t]{2}{*}{ Mid-rise Apartment } & \multicolumn{5}{|c|}{ HVAC } & \multicolumn{5}{|c|}{ Lighting } \\
\hline & $\begin{array}{c}2 \mathrm{~A} \\
\text { Houston }\end{array}$ & $\begin{array}{c}\text { 3A } \\
\text { Memphis }\end{array}$ & $\begin{array}{c}\text { 3B } \\
\text { El Paso } \\
\end{array}$ & $\begin{array}{c}4 \mathrm{~A} \\
\text { Baltimore }\end{array}$ & $\begin{array}{c}5 \mathrm{~A} \\
\text { Chicago }\end{array}$ & $\begin{array}{c}2 \mathrm{~A} \\
\text { Houston }\end{array}$ & $\begin{array}{c}\text { 3A } \\
\text { Memphis }\end{array}$ & $\begin{array}{c}\text { 3B } \\
\text { El Paso }\end{array}$ & $\begin{array}{c}4 \mathrm{~A} \\
\text { Baltimore }\end{array}$ & $\begin{array}{c}5 \mathrm{~A} \\
\text { Chicago } \\
\end{array}$ \\
\hline New Construction & $\$ 0$ & $\$ 0$ & $\$ 0$ & $\$ 0$ & $\$ 0$ & $\$ 9,430$ & $\$ 9,430$ & $\$ 9,430$ & $\$ 9,430$ & $\$ 9,430$ \\
\hline Maintenance & $\$ 0$ & $\$ 0$ & $\$ 0$ & $\$ 0$ & $\$ 0$ & $\$ 0$ & $\$ 0$ & $\$ 0$ & $\$ 0$ & $\$ 0$ \\
\hline Replacement (Year) & & & & & & & & & & \\
\hline 1 & $\$ 0$ & $\$ 0$ & $\$ 0$ & $\$ 0$ & $\$ 0$ & $-\$ 57$ & $-\$ 57$ & $-\$ 57$ & $-\$ 57$ & $-\$ 57$ \\
\hline 2 & $\$ 0$ & $\$ 0$ & $\$ 0$ & $\$ 0$ & $\$ 0$ & $-\$ 778$ & $-\$ 778$ & $-\$ 778$ & $-\$ 778$ & $-\$ 778$ \\
\hline 3 & $\$ 0$ & $\$ 0$ & $\$ 0$ & $\$ 0$ & $\$ 0$ & $-\$ 421$ & $-\$ 421$ & $-\$ 421$ & $-\$ 421$ & $-\$ 421$ \\
\hline 4 & $\$ 0$ & $\$ 0$ & $\$ 0$ & $\$ 0$ & $\$ 0$ & $-\$ 713$ & $-\$ 713$ & $-\$ 713$ & $-\$ 713$ & $-\$ 713$ \\
\hline 5 & $\$ 0$ & $\$ 0$ & $\$ 0$ & $\$ 0$ & $\$ 0$ & $\$ 1,461$ & $\$ 1,461$ & $\$ 1,461$ & $\$ 1,461$ & $\$ 1,461$ \\
\hline 6 & $\$ 0$ & $\$ 0$ & $\$ 0$ & $\$ 0$ & $\$ 0$ & $-\$ 1,142$ & $-\$ 1,142$ & $-\$ 1,142$ & $-\$ 1,142$ & $-\$ 1,142$ \\
\hline 7 & $\$ 0$ & $\$ 0$ & $\$ 0$ & $\$ 0$ & $\$ 0$ & $-\$ 57$ & $-\$ 57$ & $-\$ 57$ & $-\$ 57$ & $-\$ 57$ \\
\hline 8 & $\$ 0$ & $\$ 0$ & $\$ 0$ & $\$ 0$ & $\$ 0$ & $-\$ 713$ & $-\$ 713$ & $-\$ 713$ & $-\$ 713$ & $-\$ 713$ \\
\hline 9 & $\$ 0$ & $\$ 0$ & $\$ 0$ & $\$ 0$ & $\$ 0$ & $-\$ 421$ & $-\$ 421$ & $-\$ 421$ & $-\$ 421$ & $-\$ 421$ \\
\hline 10 & $\$ 0$ & $\$ 0$ & $\$ 0$ & $\$ 0$ & $\$ 0$ & $\$ 4,126$ & $\$ 4,126$ & $\$ 4,126$ & $\$ 4,126$ & $\$ 4,126$ \\
\hline 11 & $\$ 0$ & $\$ 0$ & $\$ 0$ & $\$ 0$ & $\$ 0$ & $-\$ 6,245$ & $-\$ 6,245$ & $-\$ 6,245$ & $-\$ 6,245$ & $-\$ 6,245$ \\
\hline 12 & $\$ 0$ & $\$ 0$ & $\$ 0$ & $\$ 0$ & $\$ 0$ & $-\$ 1,077$ & $-\$ 1,077$ & $-\$ 1,077$ & $-\$ 1,077$ & $-\$ 1,077$ \\
\hline 13 & $\$ 0$ & $\$ 0$ & $\$ 0$ & $\$ 0$ & $\$ 0$ & $-\$ 2,774$ & $-\$ 2,774$ & $-\$ 2,774$ & $-\$ 2,774$ & $-\$ 2,774$ \\
\hline 14 & $\$ 0$ & $\$ 0$ & $\$ 0$ & $\$ 0$ & $\$ 0$ & $\$ 1,607$ & $\$ 1,607$ & $\$ 1,607$ & $\$ 1,607$ & $\$ 1,607$ \\
\hline 15 & $\$ 0$ & $\$ 0$ & $\$ 0$ & $\$ 0$ & $\$ 0$ & $\$ 4,194$ & $\$ 4,194$ & $\$ 4,194$ & $\$ 4,194$ & $\$ 4,194$ \\
\hline 16 & $\$ 0$ & $\$ 0$ & $\$ 0$ & $\$ 0$ & $\$ 0$ & $-\$ 713$ & $-\$ 713$ & $-\$ 713$ & $-\$ 713$ & $-\$ 713$ \\
\hline 17 & $\$ 0$ & $\$ 0$ & $\$ 0$ & $\$ 0$ & $\$ 0$ & $-\$ 57$ & $-\$ 57$ & $-\$ 57$ & $-\$ 57$ & $-\$ 57$ \\
\hline 18 & $\$ 0$ & $\$ 0$ & $\$ 0$ & $\$ 0$ & $\$ 0$ & $\$ 5,091$ & $\$ 5,091$ & $\$ 5,091$ & $\$ 5,091$ & $\$ 5,091$ \\
\hline 19 & $\$ 0$ & $\$ 0$ & $\$ 0$ & $\$ 0$ & $\$ 0$ & $-\$ 57$ & $-\$ 57$ & $-\$ 57$ & $-\$ 57$ & $-\$ 57$ \\
\hline 20 & $\$ 0$ & $\$ 0$ & $\$ 0$ & $\$ 0$ & $\$ 0$ & $\$ 4,192$ & $\$ 4,192$ & $\$ 4,192$ & $\$ 4,192$ & $\$ 4,192$ \\
\hline 21 & $\$ 0$ & $\$ 0$ & $\$ 0$ & $\$ 0$ & $\$ 0$ & $-\$ 421$ & $-\$ 421$ & $-\$ 421$ & $-\$ 421$ & $-\$ 421$ \\
\hline 22 & $\$ 0$ & $\$ 0$ & $\$ 0$ & $\$ 0$ & $\$ 0$ & $-\$ 6,966$ & $-\$ 6,966$ & $-\$ 6,966$ & $-\$ 6,966$ & $-\$ 6,966$ \\
\hline 23 & $\$ 0$ & $\$ 0$ & $\$ 0$ & $\$ 0$ & $\$ 0$ & $-\$ 57$ & $-\$ 57$ & $-\$ 57$ & $-\$ 57$ & $-\$ 57$ \\
\hline 24 & $\$ 0$ & $\$ 0$ & $\$ 0$ & $\$ 0$ & $\$ 0$ & $-\$ 1,077$ & $-\$ 1,077$ & $-\$ 1,077$ & $-\$ 1,077$ & $-\$ 1,077$ \\
\hline 25 & $\$ 0$ & $\$ 0$ & $\$ 0$ & $\$ 0$ & $\$ 0$ & $\$ 1,461$ & $\$ 1,461$ & $\$ 1,461$ & $\$ 1,461$ & $\$ 1,461$ \\
\hline 26 & $\$ 0$ & $\$ 0$ & $\$ 0$ & $\$ 0$ & $\$ 0$ & $-\$ 3,496$ & $-\$ 3,496$ & $-\$ 3,496$ & $-\$ 3,496$ & $-\$ 3,496$ \\
\hline 27 & $\$ 0$ & $\$ 0$ & $\$ 0$ & $\$ 0$ & $\$ 0$ & $-\$ 421$ & $-\$ 421$ & $-\$ 421$ & $-\$ 421$ & $-\$ 421$ \\
\hline 28 & $\$ 0$ & $\$ 0$ & $\$ 0$ & $\$ 0$ & $\$ 0$ & $\$ 1,672$ & $\$ 1,672$ & $\$ 1,672$ & $\$ 1,672$ & $\$ 1,672$ \\
\hline 29 & $\$ 0$ & $\$ 0$ & $\$ 0$ & $\$ 0$ & $\$ 0$ & $-\$ 57$ & $-\$ 57$ & $-\$ 57$ & $-\$ 57$ & $-\$ 57$ \\
\hline 30 & $\$ 0$ & $\$ 0$ & $\$ 0$ & $\$ 0$ & $\$ 0$ & $-\$ 586$ & $-\$ 586$ & $-\$ 586$ & $-\$ 586$ & $-\$ 586$ \\
\hline
\end{tabular}




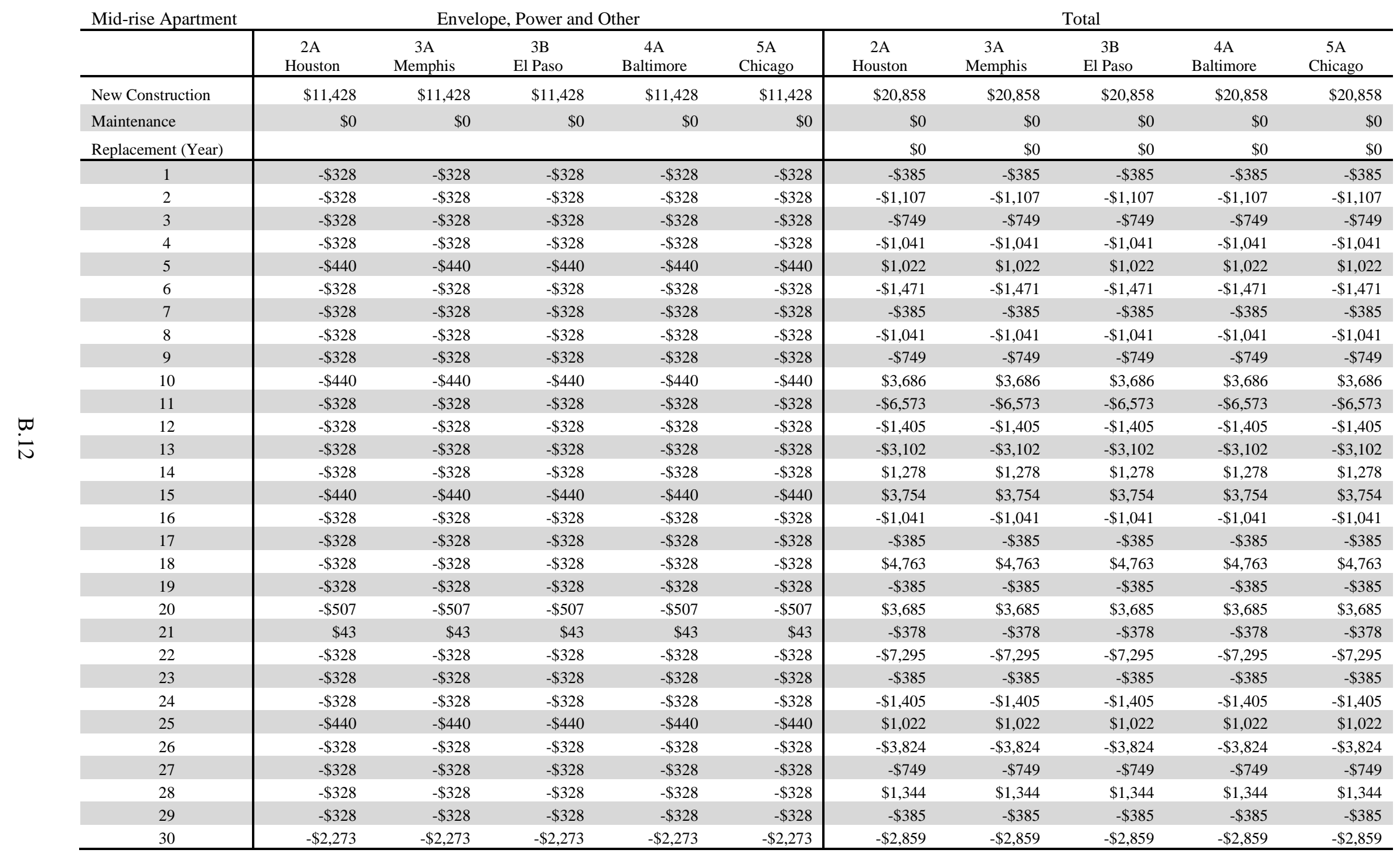


Appendix C

\section{Energy Results 90.1-2007 and 90.1-2010}




\section{C.1 Energy and Energy Cost Savings Summary With Plug and Process Loads, 90.1-2007 and 90.1-2010}

\begin{tabular}{|c|c|c|c|c|c|c|c|}
\hline Prototype Name & $\begin{array}{c}\text { \%weight } \\
\text { adjusted }\end{array}$ & $\begin{array}{c}\text { 90.1-2007 } \\
\text { Site Energy } \\
\left(\mathrm{kBtu} / \mathrm{ft}^{2}\right)\end{array}$ & $\begin{array}{c}\text { 90.1-2010 } \\
\text { Site Energy } \\
\left(\mathrm{kBtu} / \mathrm{ft}^{2}\right)\end{array}$ & $\begin{array}{c}90.1-2007 \\
\text { Site Energy } \\
\text { Cost } \\
\left(\$ / \mathrm{ft}^{2}\right) \\
\end{array}$ & $\begin{array}{c}90.1-2010 \\
\text { Site Energy } \\
\text { Cost } \\
\left(\$ / \mathrm{ft}^{2}\right) \\
\end{array}$ & $\begin{array}{l}\text { Site Energy } \\
\text { Savings } \\
\end{array}$ & $\begin{array}{c}\text { Energy Cost } \\
\text { Savings } \\
\end{array}$ \\
\hline Small Office & $5.61 \%$ & 39.3 & 32.8 & $\$ 1.12$ & $\$ 0.93$ & $16.4 \%$ & $16.7 \%$ \\
\hline Medium Office & $6.05 \%$ & 48.4 & 37.3 & $\$ 1.34$ & $\$ 1.01$ & $22.8 \%$ & $25.0 \%$ \\
\hline Large Office & $3.33 \%$ & 43.2 & 33.4 & $\$ 1.17$ & $\$ 0.92$ & $22.8 \%$ & $21.8 \%$ \\
\hline Standalone Retail & $15.25 \%$ & 65.1 & 49.5 & $\$ 1.69$ & $\$ 1.32$ & $23.9 \%$ & $21.8 \%$ \\
\hline Stripmall & $5.67 \%$ & 68.3 & 56.9 & $\$ 1.76$ & $\$ 1.42$ & $16.7 \%$ & $19.2 \%$ \\
\hline Primary School & $4.99 \%$ & 65.1 & 50.2 & $\$ 1.66$ & $\$ 1.33$ & $22.8 \%$ & $20.1 \%$ \\
\hline Secondary School & $10.36 \%$ & 56.1 & 41.2 & $\$ 1.47$ & $\$ 1.13$ & $26.6 \%$ & $23.2 \%$ \\
\hline Outpatient Healthcare & $4.37 \%$ & 153.4 & 123.6 & $\$ 3.92$ & $\$ 3.15$ & $19.4 \%$ & $19.5 \%$ \\
\hline Hospital & $3.45 \%$ & 159.8 & 118.4 & $\$ 3.58$ & $\$ 2.81$ & $25.9 \%$ & $21.5 \%$ \\
\hline Small Hotel & $1.72 \%$ & 70.8 & 66.6 & $\$ 1.61$ & $\$ 1.47$ & $5.9 \%$ & $8.7 \%$ \\
\hline Large Hotel & $4.95 \%$ & 154.4 & 125.9 & $\$ 2.85$ & $\$ 2.42$ & $18.4 \%$ & $14.9 \%$ \\
\hline Warehouse & $16.72 \%$ & 24.0 & 19.0 & $\$ 0.55$ & $\$ 0.42$ & $21.0 \%$ & $24.2 \%$ \\
\hline Quick Service Restaurant & $0.59 \%$ & 548.4 & 519.9 & $\$ 10.01$ & $\$ 9.12$ & $5.2 \%$ & $8.9 \%$ \\
\hline Full Service Restaurant & $0.66 \%$ & 383.1 & 330.9 & $\$ 7.61$ & $\$ 6.12$ & $13.6 \%$ & $19.6 \%$ \\
\hline Mid-rise Apartment & $7.32 \%$ & 44.3 & 41.2 & $\$ 1.17$ & $\$ 1.11$ & $7.1 \%$ & $4.8 \%$ \\
\hline High-rise Apartment & $8.97 \%$ & 47.7 & 44.0 & $\$ 1.32$ & $\$ 1.25$ & $7.8 \%$ & $5.3 \%$ \\
\hline Totals & $100.0 \%$ & & & & & & \\
\hline National Weighted Average & & 67.8 & 55.0 & $\$ 1.64$ & $\$ 1.35$ & $18.9 \%$ & $18.1 \%$ \\
\hline
\end{tabular}




\section{C.2 Energy and Energy Cost Savings Summary Without Plug and Process Loads, 90.1-2007 and 90.1-2010}

\begin{tabular}{|c|c|c|c|c|c|c|c|}
\hline Prototype Name & $\begin{array}{c}\text { \%weight } \\
\text { adjusted }\end{array}$ & $\begin{array}{c}90.1-2007 \\
\text { Site Energy } \\
\left(\mathrm{kBtu} / \mathrm{ft}^{2}\right) \\
\end{array}$ & $\begin{array}{c}90.1-2010 \\
\text { Site Energy } \\
\left(\mathrm{kBtu} / \mathrm{ft}^{2}\right) \\
\end{array}$ & $\begin{array}{c}90.1-2007 \\
\text { Site Energy } \\
\text { Cost } \\
\left(\$ / \mathrm{ft}^{2}\right) \\
\end{array}$ & $\begin{array}{c}90.1-2010 \\
\text { Site Energy } \\
\text { Cost } \\
(\$ / \mathrm{ft} 2) \\
\end{array}$ & $\begin{array}{c}\text { Site Energy } \\
\text { Savings }\end{array}$ & $\begin{array}{c}\text { Energy Cost } \\
\text { Savings } \\
\end{array}$ \\
\hline Small Office & $5.61 \%$ & 30.2 & 24.4 & $\$ 0.84$ & $\$ 0.66$ & $19.21 \%$ & $22.18 \%$ \\
\hline Medium Office & $6.05 \%$ & 33.3 & 23.9 & $\$ 0.89$ & $\$ 0.56$ & $28.44 \%$ & $36.81 \%$ \\
\hline Large Office & $3.33 \%$ & 27.6 & 19.2 & $\$ 0.81$ & $\$ 0.56$ & $30.15 \%$ & $30.80 \%$ \\
\hline Standalone Retail & $15.25 \%$ & 57.6 & 42.1 & $\$ 1.47$ & $\$ 1.10$ & $27.03 \%$ & $25.20 \%$ \\
\hline Stripmall & $5.67 \%$ & 62.9 & 51.5 & $\$ 1.59$ & $\$ 1.26$ & $18.18 \%$ & $21.11 \%$ \\
\hline Primary School & $4.99 \%$ & 43.8 & 29.3 & $\$ 1.16$ & $\$ 0.83$ & $33.08 \%$ & $28.09 \%$ \\
\hline Secondary School & $10.36 \%$ & 41.7 & 27.1 & $\$ 1.11$ & $\$ 0.78$ & $34.90 \%$ & $30.15 \%$ \\
\hline Outpatient Healthcare & $4.37 \%$ & 106.2 & 77.2 & $\$ 2.63$ & $\$ 1.86$ & $27.32 \%$ & $29.15 \%$ \\
\hline Hospital & $3.45 \%$ & 110.2 & 69.4 & $\$ 2.71$ & $\$ 1.96$ & $36.98 \%$ & $27.85 \%$ \\
\hline Small Hotel & $1.72 \%$ & 48.4 & 44.4 & $\$ 1.22$ & $\$ 1.07$ & $8.18 \%$ & $11.54 \%$ \\
\hline Large Hotel & $4.95 \%$ & 118.9 & 90.9 & $\$ 2.43$ & $\$ 2.01$ & $23.57 \%$ & $17.22 \%$ \\
\hline Warehouse & $16.72 \%$ & 21.5 & 16.5 & $\$ 0.47$ & $\$ 0.34$ & $23.01 \%$ & $28.10 \%$ \\
\hline Quick Service Restaurant & $0.59 \%$ & 279.0 & 250.6 & $\$ 7.34$ & $\$ 6.46$ & $10.16 \%$ & $12.09 \%$ \\
\hline Full Service Restaurant & $0.66 \%$ & 229.7 & 178.1 & $\$ 5.43$ & $\$ 3.94$ & $22.49 \%$ & $27.50 \%$ \\
\hline Mid-rise Apartment & $7.32 \%$ & 29.8 & 26.8 & $\$ 0.73$ & $\$ 0.67$ & $9.95 \%$ & $7.72 \%$ \\
\hline High-rise Apartment & $8.97 \%$ & 34.5 & 31.0 & $\$ 0.92$ & $\$ 0.86$ & $10.02 \%$ & $6.99 \%$ \\
\hline Totals & $100.0 \%$ & & & & & & \\
\hline National Weighted Average & & 50.7 & 38.2 & $\$ 1.26$ & $\$ 0.96$ & $24.51 \%$ & $23.43 \%$ \\
\hline
\end{tabular}




\section{C.3 Energy By Usage Category, 90.1-2007 and 90.1-2010}

\begin{tabular}{|c|c|c|c|c|c|c|c|c|c|c|c|c|c|c|c|c|c|c|c|c|c|c|c|c|c|}
\hline \multirow[b]{3}{*}{$\begin{array}{l}\text { Prototype } \\
\text { Name }\end{array}$} & \multirow[b]{3}{*}{$\begin{array}{c}\text { \%weight } \\
\text { adjusted }\end{array}$} & \multicolumn{24}{|c|}{ Site Energy Use Index kBtu/ft ${ }^{2}$} \\
\hline & & \multicolumn{2}{|c|}{ Interior Lights } & \multicolumn{2}{|c|}{ Exterior Lights } & \multicolumn{2}{|c|}{ Plug Loads } & \multicolumn{2}{|c|}{ Fans } & \multicolumn{2}{|c|}{ Pumps } & \multicolumn{2}{|c|}{ Heat Recovery } & \multicolumn{2}{|c|}{ Cooling } & \multicolumn{2}{|c|}{ Heating } & \multicolumn{2}{|c|}{ SWH } & \multicolumn{2}{|c|}{ Humidifcation } & \multicolumn{2}{|c|}{ Refrigeration } & \multicolumn{2}{|c|}{ Total } \\
\hline & & 2007 & 2010 & 2007 & 2010 & 2007 & 2010 & 2007 & 2010 & 2007 & 2010 & 2007 & 2010 & 2007 & 2010 & 2007 & 2010 & 2007 & 2010 & 2007 & 2010 & 2007 & 2010 & \begin{tabular}{l|} 
Base- \\
Site \\
Energy
\end{tabular} & $\begin{array}{l}\text { Target- } \\
\text { Site } \\
\text { Energy }\end{array}$ \\
\hline Small Office & $5.61 \%$ & 12.2 & 10.2 & 4.4 & 1.6 & 9.1 & 8.4 & 4.2 & 3.9 & 0.0 & 0.0 & 0.0 & 0.0 & 3.9 & 3.7 & 3.5 & 3.2 & 1.8 & 1.8 & 0.0 & 0.0 & 0.0 & 0.0 & 39.3 & 32.8 \\
\hline $\begin{array}{l}\text { Medium } \\
\text { Office }\end{array}$ & $6.05 \%$ & 9.8 & 6.8 & 4.0 & 1.4 & 15.0 & 13.5 & 1.8 & 1.5 & 0.0 & 0.0 & 0.0 & 0.0 & 8.0 & 5.9 & 6.3 & 4.7 & 3.5 & 3.5 & 0.0 & 0.0 & 0.0 & 0.0 & 48.4 & 37.3 \\
\hline Large Office & $3.33 \%$ & 9.8 & 7.2 & 1.9 & 1.0 & 15.6 & 14.1 & 1.9 & 1.6 & 1.7 & 1.1 & 0.0 & 0.0 & 5.9 & 3.9 & 5.8 & 3.8 & 0.6 & 0.6 & 0.0 & 0.0 & 0.0 & 0.0 & 43.2 & 33.4 \\
\hline $\begin{array}{l}\text { Standalone } \\
\text { Retail }\end{array}$ & $15.25 \%$ & 18.8 & 17.0 & 4.4 & 1.8 & 7.5 & 7.5 & 12.0 & 8.2 & 0.0 & 0.0 & 0.0 & 0.6 & 9.1 & 6.1 & 12.1 & 7.1 & 1.2 & 1.2 & 0.0 & 0.0 & 0.0 & 0.0 & 65.1 & 49.5 \\
\hline Stripmall & $5.67 \%$ & 22.8 & 18.8 & 6.1 & 2.3 & 5.4 & 5.4 & 9.4 & 8.2 & 0.0 & 0.0 & 0.0 & 0.0 & 9.7 & 7.6 & 13.1 & 12.7 & 1.8 & 1.9 & 0.0 & 0.0 & 0.0 & 0.0 & 68.3 & 56.9 \\
\hline $\begin{array}{l}\text { Primary } \\
\text { School }\end{array}$ & $4.99 \%$ & 15.5 & 10.4 & 1.1 & 0.5 & 21.3 & 20.9 & 5.4 & 4.6 & 0.0 & 0.0 & 0.0 & 0.7 & 10.4 & 7.5 & 9.4 & 3.7 & 1.0 & 1.0 & 0.0 & 0.0 & 1.0 & 1.0 & 65.1 & 50.2 \\
\hline $\begin{array}{l}\text { Secondary } \\
\text { School }\end{array}$ & $10.36 \%$ & 14.8 & 9.7 & 1.0 & 0.4 & 14.4 & 14.0 & 5.6 & 4.5 & 0.5 & 0.2 & 0.0 & 0.8 & 10.8 & 8.0 & 7.8 & 2.4 & 0.5 & 0.5 & 0.0 & 0.0 & 0.7 & 0.7 & 56.1 & 41.2 \\
\hline $\begin{array}{l}\text { Outpatient } \\
\text { Healthcare }\end{array}$ & $4.37 \%$ & 14.2 & 12.3 & 5.3 & 3.0 & 47.3 & 46.5 & 12.3 & 9.4 & 0.4 & 0.4 & 0.0 & 0.0 & 25.2 & 18.6 & 43.6 & 29.4 & 1.1 & 1.1 & 4.1 & 2.8 & 0.0 & 0.0 & 153.4 & 123.6 \\
\hline Hospital & $3.45 \%$ & 16.6 & 14.2 & 1.0 & 0.8 & 49.6 & 49.0 & 16.7 & 11.4 & 5.6 & 3.4 & 0.0 & 0.5 & 19.0 & 11.7 & 49.4 & 25.6 & 1.1 & 1.1 & 0.0 & 0.0 & 0.8 & 0.8 & 159.8 & 118.4 \\
\hline Small Hotel & $1.72 \%$ & 10.9 & 9.0 & 2.1 & 1.4 & 22.5 & 22.2 & 8.4 & 7.9 & 0.0 & 0.0 & 0.0 & 0.0 & 8.5 & 7.3 & 7.3 & 7.5 & 11.2 & 11.2 & 0.0 & 0.0 & 0.0 & 0.0 & 70.8 & 66.6 \\
\hline Large Hotel & $4.95 \%$ & 11.3 & 10.6 & 2.4 & 1.8 & 35.4 & 35.0 & 5.9 & 5.1 & 2.0 & 0.7 & 0.0 & 1.3 & 21.0 & 16.4 & 27.6 & 6.1 & 48.2 & 48.2 & 0.0 & 0.0 & 0.6 & 0.6 & 154.4 & 125.9 \\
\hline Warehouse & $16.72 \%$ & 8.8 & 6.1 & 2.2 & 1.2 & 2.5 & 2.4 & 1.0 & 0.8 & 0.0 & 0.0 & 0.0 & 0.0 & 0.6 & 0.5 & 8.8 & 7.8 & 0.1 & 0.1 & 0.0 & 0.0 & 0.0 & 0.0 & 24.0 & 19.0 \\
\hline $\begin{array}{l}\text { Quick } \\
\text { Service } \\
\text { Restaurant }\end{array}$ & $0.59 \%$ & 28.5 & 13.5 & 10.4 & 4.4 & 274.6 & 274.5 & 35.6 & 32.9 & 0.0 & 0.0 & 0.0 & 0.0 & 31.5 & 25.3 & 119.0 & 120.6 & 24.2 & 24.2 & 0.0 & 0.0 & 24.6 & 24.6 & 548.4 & 519.9 \\
\hline $\begin{array}{l}\text { Full Service } \\
\text { Restaurant }\end{array}$ & $0.66 \%$ & 32.0 & 13.5 & 10.0 & 4.3 & 157.6 & 157.1 & 30.3 & 16.0 & 0.0 & 0.0 & 0.0 & 0.0 & 27.7 & 18.4 & 81.3 & 77.5 & 33.3 & 33.3 & 0.0 & 0.0 & 10.9 & 10.9 & 383.1 & 330.9 \\
\hline $\begin{array}{l}\text { Mid-rise } \\
\text { Apartment }\end{array}$ & $7.32 \%$ & 2.8 & 2.9 & 2.0 & 1.1 & 14.5 & 14.4 & 5.2 & 5.0 & 0.0 & 0.0 & 0.0 & 0.0 & 4.0 & 4.0 & 8.3 & 6.4 & 7.4 & 7.4 & 0.0 & 0.0 & 0.0 & 0.0 & 44.3 & 41.2 \\
\hline $\begin{array}{l}\text { High-rise } \\
\text { Apartment }\end{array}$ & $8.97 \%$ & 2.6 & 2.7 & 2.2 & 1.7 & 13.2 & 13.0 & 5.2 & 4.9 & 0.7 & 0.5 & 0.0 & 0.0 & 9.0 & 9.0 & 7.3 & 4.8 & 7.4 & 7.4 & 0.0 & 0.0 & 0.0 & 0.0 & 47.7 & 44.0 \\
\hline Totals & $100.0 \%$ & & & & & & & & & & & & & & & & & & & & & & & & \\
\hline National & & 12.3 & 9.8 & 3.0 & 1.4 & 17.2 & 16.8 & 6.6 & 5.2 & 0.5 & 0.3 & 0.0 & 0.3 & 9.0 & 6.8 & 13.7 & 8.8 & 5.0 & 5.0 & 0.2 & 0.1 & 0.4 & 0.4 & 67.8 & 55.0 \\
\hline Weighted & & & $51 \%$ & & $2 \%$ & 2.1 & $9 \%$ & 20.7 & $79 \%$ & & $4 \%$ & & A & 23.8 & $88 \%$ & & $10 \%$ & 0.0 & $1 \%$ & & $84 \%$ & & $71 \%$ & 18.8 & $88 \%$ \\
\hline
\end{tabular}




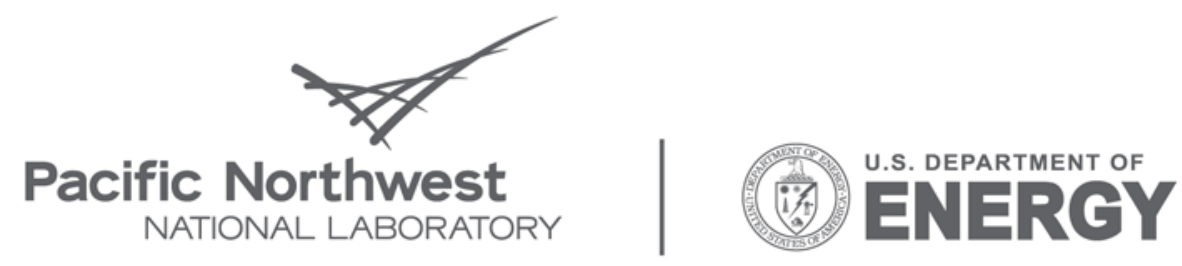

Proudly Operated by Battelle Since 1965

902 Battelle Boulevard

P.O. Box 999

Richland, WA 99352

1-888-375-PNNL (7665)

www.pnl.gov 